\title{
SUBTASK 4.24 - FIELD EVALUATION OF NOVEL APPROACH FOR OBTAINING METAL EMISSION DATA
}

Final Report

(for the period July 15, 2011, through December 31, 2013)

Prepared for:

AAD Document Control

National Energy Technology Laboratory

U.S. Department of Energy

626 Cochrans Mill Road

PO Box 10940, MS 921-107

Pittsburgh, PA 15236-0940

Cooperative Agreement No. DE-FC26-08NT43291

DOE Technical Monitor: Barbara Carney

Prepared by:

John H. Pavlish Dennis L. Laudal Jeffrey S. Thompson

Energy \& Environmental Research Center University of North Dakota 15 North 23rd Street, Stop 9018

Grand Forks, ND 58202-9018 


\section{EERC DISCLAIMER}

LEGAL NOTICE This research report was prepared by the Energy \& Environmental Research Center (EERC), an agency of the University of North Dakota, as an account of work sponsored by the U.S. Department of Energy, North Dakota Industrial Commission, Great River Energy, Minnesota Power, SaskPower, the Electric Power Research Institute, Montana-Dakota Utilities Co., Ohio Lumex, and Center for Air Toxic Metals ${ }^{\circledR}$ Affiliates. Because of the research nature of the work performed, neither the EERC nor any of its employees makes any warranty, express or implied, or assumes any legal liability or responsibility for the accuracy, completeness, or usefulness of any information, apparatus, product, or process disclosed or represents that its use would not infringe privately owned rights. Reference herein to any specific commercial product, process, or service by trade name, trademark, manufacturer, or otherwise does not necessarily constitute or imply its endorsement or recommendation by the EERC.

\section{DOE DISCLAIMER}

This report was prepared as an account of work sponsored by an agency of the United States Government. Neither the United States Government, nor any agency thereof, nor any of their employees, makes any warranty, express or implied, or assumes any legal liability or responsibility for the accuracy, completeness, or usefulness of any information, apparatus, product, or process disclosed, or represents that its use would not infringe privately owned rights. Reference herein to any specific commercial product, process, or service by trade name, trademark, manufacturer, or otherwise does not necessarily constitute or imply its endorsement, recommendation, or favoring by the United States Government or any agency thereof. The views and opinions of authors expressed herein do not necessarily state or reflect those of the United States Government or any agency thereof.

\section{NDIC DISCLAIMER}

This report was prepared by the EERC pursuant to an agreement partially funded by the Industrial Commission of North Dakota, and neither the EERC nor any of its subcontractors nor the North Dakota Industrial Commission nor any person acting on behalf of either:

(A) Makes any warranty or representation, express or implied, with respect to the accuracy, completeness, or usefulness of the information contained in this report or that the use of any information, apparatus, method, or process disclosed in this report may not infringe privately owned rights; or

(B) Assumes any liabilities with respect to the use of, or for damages resulting from the use of, any information, apparatus, method, or process disclosed in this report.

Reference herein to any specific commercial product, process, or service by trade name, trademark, manufacturer, or otherwise does not necessarily constitute or imply its endorsement, recommendation, or favoring by the North Dakota Industrial Commission. The views and opinions of authors expressed herein do not necessarily state or reflect those of the North Dakota Industrial Commission. 


\title{
SUBTASK 4.24 - FIELD EVALUATION OF NOVEL APPROACH FOR OBTAINING METAL EMISSION DATA
}

\begin{abstract}
Over the past two decades, emissions of mercury, nonmercury metals, and acid gases from energy generation and chemical production have increasingly become an environmental concern. On February 16, 2012, the U.S. Environmental Protection Agency (EPA) promulgated the Mercury and Air Toxics Standards (MATS) to reduce mercury, nonmercury metals, and $\mathrm{HCl}$ emissions from coal-fired power plants. The current reference methods for trace metals and halogens are wet-chemistry methods, EPA Method (M) 29 and M26A, respectively. As a possible alternative to EPA M29 and M26A, the Energy \& Environmental Research Center (EERC) has developed a novel multielement sorbent trap (ME-ST) method to be used to sample for trace elements and/or halogens. Testing was conducted at three different power plants, and the results show that for halogens, the ME-ST halogen (ME-ST-H) method did not show any significant bias compared to EPA M26A and appears to be a potential candidate to serve as an alternative to the reference method. For metals, the ME-ST metals (ME-ST-M) method offers a lower detection limit compared to EPA M29 and generally produced comparable data for Sb, As, $\mathrm{Be}, \mathrm{Cd}, \mathrm{Co}, \mathrm{Hg}$, and Se. Both the ME-ST-M and M29 had problems associated with high blanks for $\mathrm{Ni}, \mathrm{Pb}, \mathrm{Cr}$, and $\mathrm{Mn}$. Although this problem has been greatly reduced through improved trap design and material selection, additional research is still needed to explore possible longer sampling durations and/or selection of lower background materials before the ME-ST-M can be considered as a potential alternative method for all the trace metals listed in MATS.
\end{abstract}

This subtask was funded through the EERC-U.S. Department of Energy Joint Program on Research and Development for Fossil Energy-Related Resources Cooperative Agreement No. DE-FC26-08NT43291. Nonfederal funding was provided by the North Dakota Industrial Commission, Great River Energy, Minnesota Power, SaskPower, the Electric Power Research Institute, Montana-Dakota Utilities Co., Ohio Lumex, and Center for Air Toxic Metals ${ }^{\circledR}$ Affiliates. 


\section{TABLE OF CONTENTS}

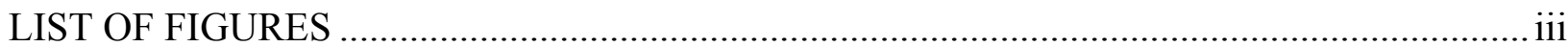

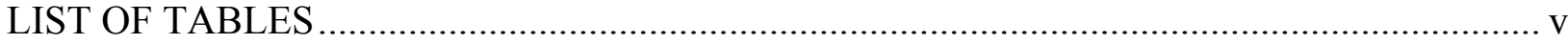

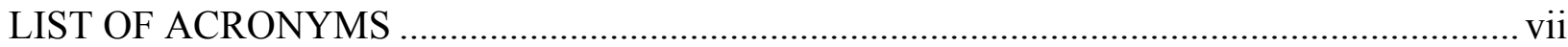

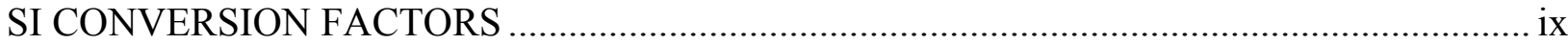

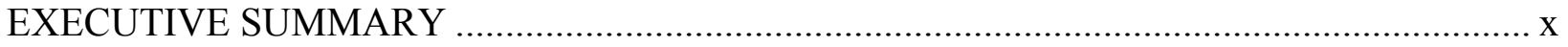

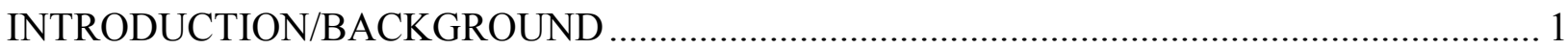

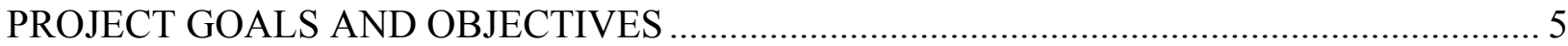

EXPERIMENTAL METHODS AND SAMPLING APPROACH ……......................................... 7

EPA Standard Sampling Methods................................................................................. 7

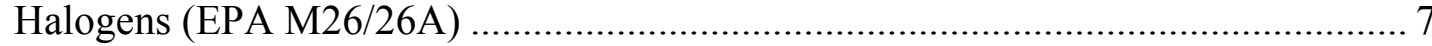

Mercury and Nonmercury Metal HAPs (EPA M29) ................................................ 9

ME-ST Sorbent Trap Sampling Methods..................................................................... 11

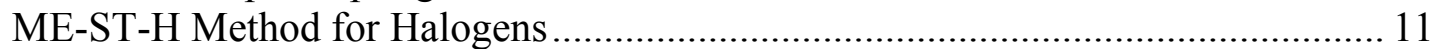

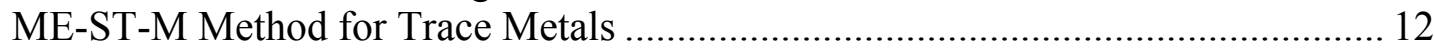

Halogen Analysis ................................................................................................. 14

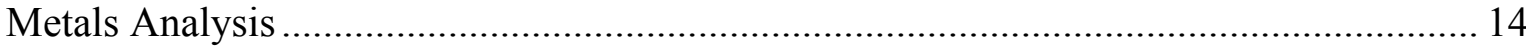

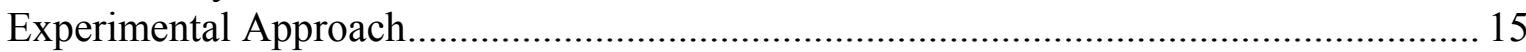

DESCRIPTION OF POWER PLANTS AND COAL ANALYSIS ……………...................... 17

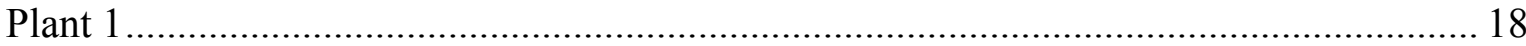

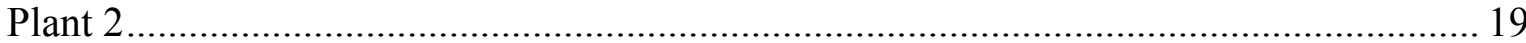

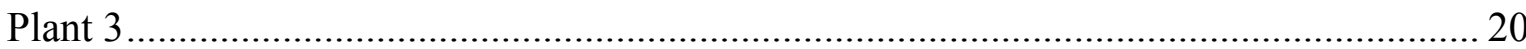

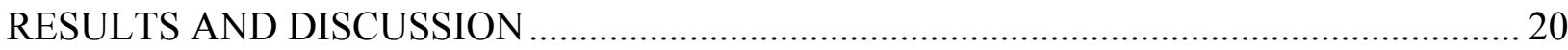

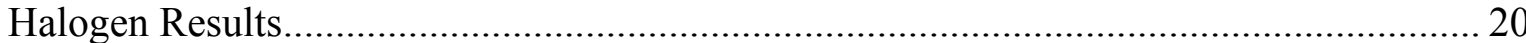

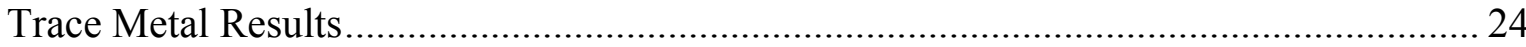

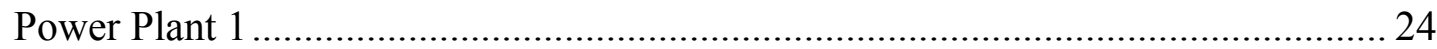

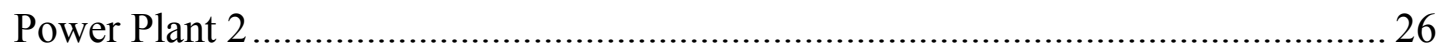

Power Plant 3 ............................................................................................. 28

Statistical Comparison of the ME-ST Method to Reference Methods................................... 31

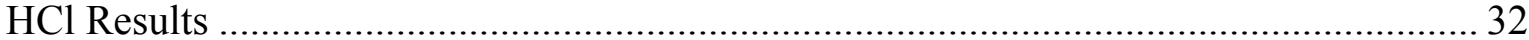

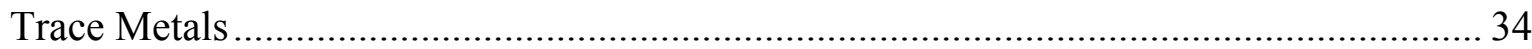

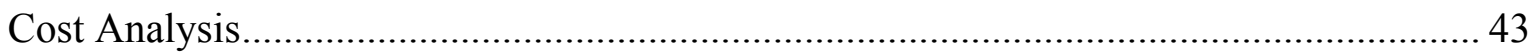

Continued... 


\section{TABLE OF CONTENTS (continued)}

QUALITY ASSURANCE/QUALITY CONTROL ........................................................... 43

CONCLUSIONS AND RECOMMENDATIONS ........................................................ 49

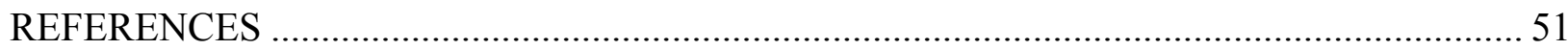

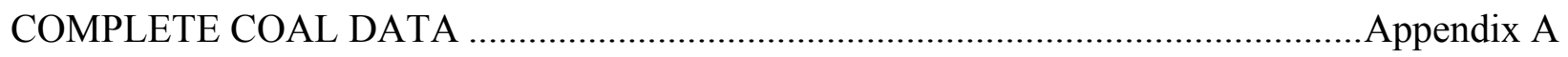

STACK EMISSION MEASUREMENT DATA ..................................................... Appendix B

HALOGEN STACK EMISSION MEASUREMENT DATA.................................Appendix B1

METAL STACK EMISSION MEASUREMENT DATA ...................................... Appendix B2

ELEMENT-BY-ELEMENT METHOD COMPARISON .........................................Appendix C 


\section{LIST OF FIGURES}

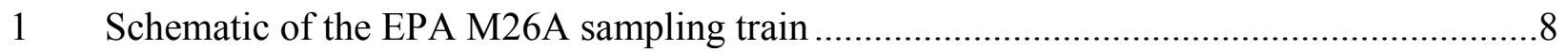

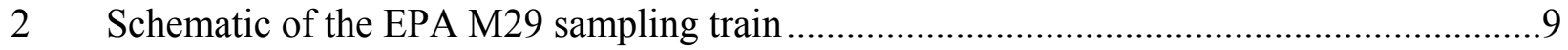

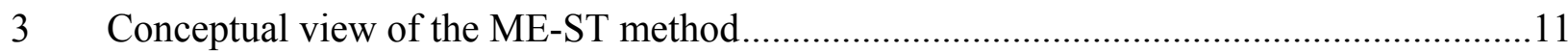

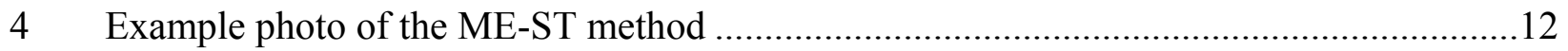

5 Improvement in background concentrations of $\mathrm{Cr}, \mathrm{Pb}, \mathrm{Mn}, \mathrm{Ni}$, and $\mathrm{Se} . . . \ldots \ldots \ldots \ldots \ldots \ldots \ldots \ldots \ldots . . . . .13$

6 Improvement in background concentrations of $\mathrm{Sb}, \mathrm{As}, \mathrm{Be}, \mathrm{Cd}$, and $\mathrm{Co}$.............................13

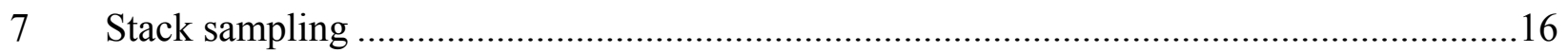

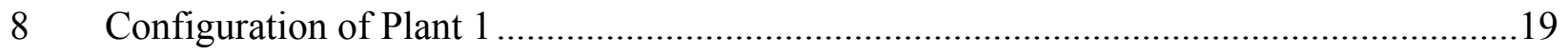

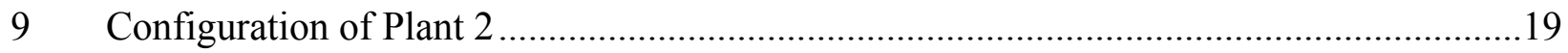

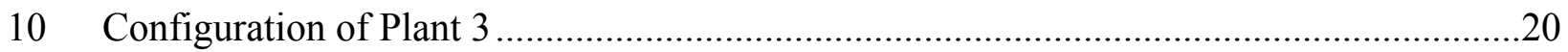

11 Comparison of sampling results for EPA M26A and the ME-ST-H method for $\mathrm{HCl}$ at

Power Plant 1 ......................................................................................................22

12 Comparison of sampling results for EPA M26A and the ME-ST-H method for $\mathrm{HCl}$ at

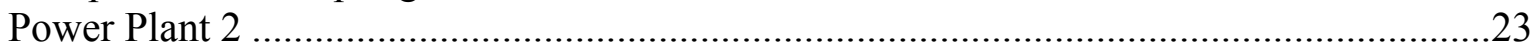

13 Comparison of sampling results for EPA M26A and the ME-ST-H method for $\mathrm{HCl}$ at

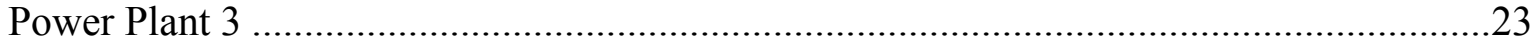

14 Comparison of sampling results for EPA M29 and the ME-ST-M method for Plant 1......26

15 Comparison of sampling results for EPA M29 and the ME-ST-M method for Plant 2......29

16 Comparison of sampling results for EPA M29 and the ME-ST-M method for Plant 3.......31

17 Average flue gas $\mathrm{HCl}$ results comparing EPA M26A with ME-ST-H ……........................33

18 Comparison of ME-ST-M and EPA M29 data for As ........................................................

19 Comparison of ME-ST-M and EPA M29 data for Be ......................................................

Continued... 


\section{LIST OF FIGURES (continued)}

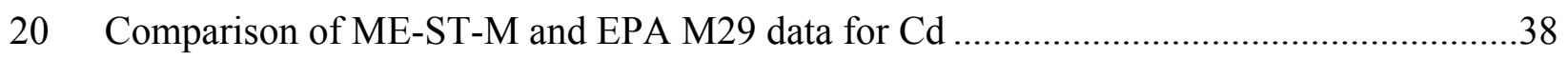

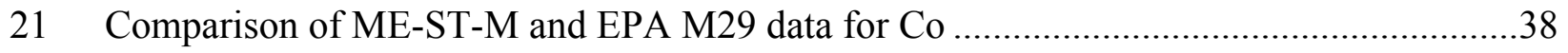

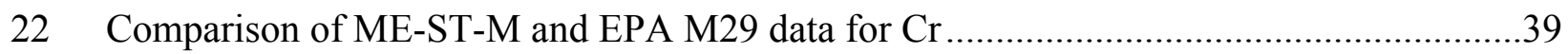

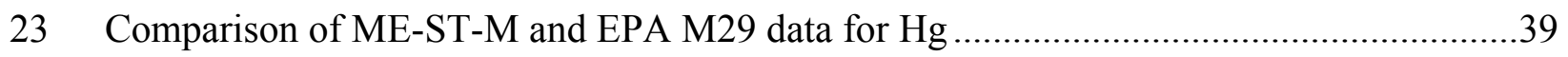

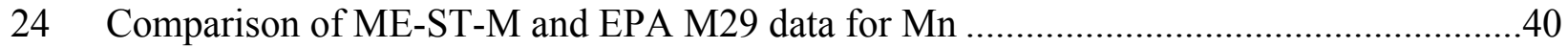

25 Comparison of ME-ST-M and EPA M29 data for Ni ..............................................40

26 Comparison of ME-ST-M and EPA M29 data for Pb.................................................41

27 Comparison of ME-ST-M and EPA M29 data for Sb..............................................41

28 Comparison of ME-ST-M and EPA M29 data for Se ...............................................42 


\section{LIST OF TABLES}

1 Emission Limitations for Coal-Fired and Solid Oil-Derived Fuel-Fired EGUs ..................2

2 Emission Limitations for New Coal-Fired and Solid Oil-Derived Fuel-Fired EGUs ...........2

3 Emission Limits for Major Industrial Boiler and Process Heaters.......................................

4 Alternate Emission Limitations for Existing Coal- and Oil-Fired EGUs ..........................4

$5 \quad$ MATS Limits and Corresponding Flue Gas Concentrations for $\mathrm{HCl}$ Emissions from

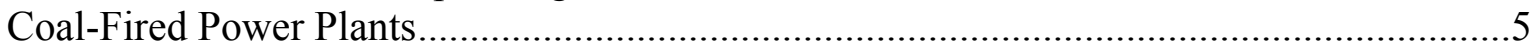

6 MATS Limits and Corresponding Flue Gas Concentrations for Metal Emissions for

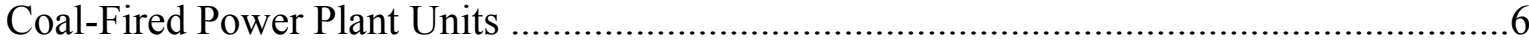

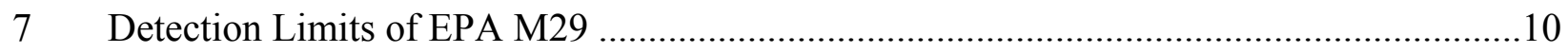

8 Estimated Detection Limits of EPA M29 and the ME-ST-M Method.............................15

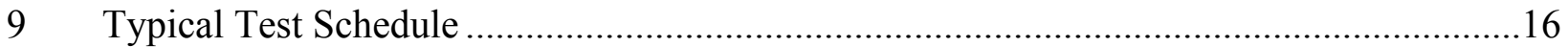

10 Daily Test Matrix and Associated Sampling ........................................................... 17

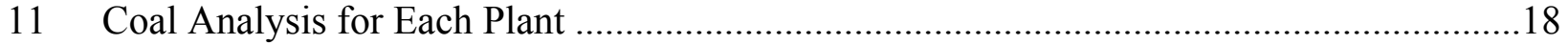

12 Comparison of EPA M26A and the ME-ST-H Method for $\mathrm{HCl}$ at Plant 1 .....................21

13 Comparison of EPA M26A and the ME-ST-H Method for $\mathrm{HCl}$ at Plant 2 ....................21

14 Comparison of EPA M26A and the ME-ST-H Method for $\mathrm{HCl}$ at Plant 3 .....................22

15 Plant 1 Flue Gas Trace Metal Concentrations as Measured Using EPA M29 _..................25

16 Plant 1 Flue Gas Trace Metal Concentrations as Measured Using the ME-ST-M

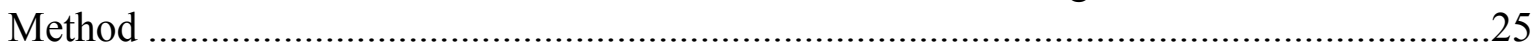

17 Trace Metal Capture at Plant 1 Using EPA M29 and ME-ST-M Data.............................25

18 Plant 2 Flue Gas Trace Metal Concentrations as Measured Using EPA M29 _..................27

19 Plant 2 Flue Gas Trace Metal Concentrations as Measured Using the ME-ST-M Method

Continued... 


\section{LIST OF TABLES (continued)}

20 Trace Metals Capture at Plant 2 Using EPA M29 and ME-ST-M Data ...........................28

21 Plant 3 Flue Gas Trace Metal Concentrations as Measured Using EPA M29 ..................29

22 Plant 3 Flue Gas Trace Metal Concentrations as Measured Using the ME-ST-M

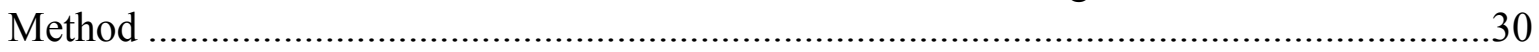

23 Trace Metals Capture at Plant 3 Using EPA M29 and ME-ST-M Data ...........................30

24 Average Concentrations and Statistical Analysis of HCl Results for EPA M26A

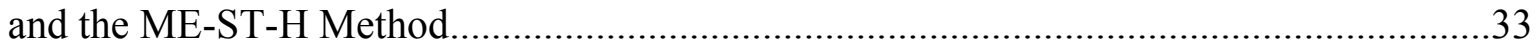

25 Statistical Comparison of the Average Trace Metal Results for EPA M29 and

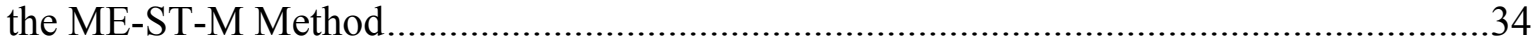

26 Cost Analysis Comparing the EPA Reference Methods to the ME-ST Methods ...............44

27 Power Plant 1 ME-ST-H Duplicate Sample Trap Results ............................................45

28 Power Plant 2 ME-ST-H Duplicate Sample Trap Results ...........................................45

29 Power Plant 3 ME-ST-H Duplicate Sample Trap Results ...........................................46

30 Power Plant 1 ME-ST-M Duplicate Sample Trap Results............................................46

31 Power Plant 2 ME-ST-M Duplicate Sample Trap Results...........................................47

32 Power Plant 3 ME-ST-M Duplicate Sample Trap Results...........................................48 


\section{LIST OF ACRONYMS}

\begin{tabular}{|c|c|}
\hline ARL & EERC Analytical Research Laboratory \\
\hline ASTM & ASTM (American Society for Testing Materials) International \\
\hline $\mathrm{CCV}$ & continuing calibration verification \\
\hline CEM & continuous emission monitor \\
\hline CVAAS & cold-vapor atomic adsorption spectroscopy \\
\hline DOE & U.S. Department of Energy \\
\hline EERC & Energy \& Environmental Research Center \\
\hline EGU & electric generating unit \\
\hline EPA & U.S. Environmental Protection Agency \\
\hline $\mathrm{Eq}$ & equivalent \\
\hline ESP & electrostatic precipitator \\
\hline FGD & flue gas desulfurization \\
\hline GFAAS & graphite furnace atomic adsorption spectroscopy \\
\hline GWh & gigawatt hour \\
\hline HAP & hazardous air pollutant \\
\hline $\mathrm{IC}$ & ion chromatography \\
\hline ICP-AES & inductively coupled plasma-atomic emission spectroscopy \\
\hline $\mathrm{ICP}-\mathrm{MS}$ & inductively coupled plasma-mass spectroscopy \\
\hline $\mathrm{ICV}$ & initial calibration verification \\
\hline IGCC & integrated gasification combined cycle \\
\hline $\mathrm{lb}$ & pound \\
\hline LNB & low- $\mathrm{NO}_{\mathrm{x}}$ burner \\
\hline LOQ & limit of quantitatation \\
\hline M & method \\
\hline MATS & Mercury and Air Toxics Standards \\
\hline MDL & method detection limit \\
\hline ME-ST & multielement sorbent trap \\
\hline ME-ST-H & multielement sorbent trap (halogen) \\
\hline ME-ST-M & multielement sorbent trap (multimetal) \\
\hline $\mathrm{mg} / \mathrm{L}$ & milligram per liter \\
\hline $\mathrm{mm}$ & millimeter \\
\hline MMBtu & million British thermal unit \\
\hline MWh & megawatt hour \\
\hline NA & not applicable \\
\hline ND & nondetect \\
\hline NESHAPs & National Emission Standards for Hazardous Air Pollutants \\
\hline NIST & National Institute of Standards and Technology \\
\hline NR & not revised \\
\hline NS & not significant \\
\hline NSPS & New Source Performance Standards \\
\hline OFA & overfire air \\
\hline PM & particulate matter \\
\hline
\end{tabular}

Continued... 


\section{LIST OF ACRONYMS (continued)}

$\begin{array}{ll}\operatorname{ppm}(v) & \text { parts per million by volume } \\ \text { PRB } & \text { Powder River Basin } \\ \text { QA/QC } & \text { quality assurance/quality control } \\ \text { RD } & \text { relative difference } \\ \text { RSD } & \text { relative standard deviation } \\ \text { SSTP } & \text { site-specific test plan } \\ \text { TBtu } & \text { trillion British thermal unit } \\ \mu \mathrm{g} / \mathrm{dNm}^{3} & \text { microgram per dry normal cubic meter (corrected to } 20^{\circ} \mathrm{C} \text { ) }\end{array}$




\section{SI CONVERSION FACTORS}

\section{English (US) units $\times$ Factor $=$ SI units}

\begin{tabular}{|c|c|c|c|c|c|}
\hline Area: & $1 \mathrm{ft}^{2}$ & $\times$ & $9.29 \times 10^{-2}$ & $=$ & $\mathrm{m}^{2}$ \\
\hline \multirow[t]{2}{*}{ Flow Rate: } & $1 \mathrm{gal} / \mathrm{min}$ & $x$ & $6.31 \times 10^{-5}$ & $=$ & $\mathrm{m}^{3} / \mathrm{s}$ \\
\hline & $1 \mathrm{gal} / \mathrm{min}$ & $x$ & $6.31 \times 10^{-2}$ & $=$ & $\mathrm{L} / \mathrm{s}$ \\
\hline \multirow[t]{3}{*}{ Length: } & $1 \mathrm{ft}$ & $x$ & 0.3048 & $=$ & $\mathrm{m}$ \\
\hline & $1 \mathrm{in.}$ & $x$ & 2.54 & $=$ & $\mathrm{cm}$ \\
\hline & $1 \mathrm{yd}$ & $x$ & 0.9144 & $=$ & $\mathrm{m}$ \\
\hline \multirow[t]{4}{*}{ Mass: } & $1 \mathrm{lb}$ & $x$ & 454 & $=$ & $\mathrm{g}$ \\
\hline & $1 \mathrm{lb}$ & $x$ & 0.454 & $=$ & $\mathrm{kg}$ \\
\hline & $1 \mathrm{gr}$ & $x$ & 0.0648 & $=$ & $\mathrm{g}$ \\
\hline & 1 ton & $x$ & 0.907 & & tonne \\
\hline \multirow[t]{4}{*}{ Volume: } & $1 \mathrm{ft}^{3}$ & $\times$ & 28.3 & $=$ & $\mathrm{L}$ \\
\hline & $1 \mathrm{ft}^{3}$ & $x$ & 0.0283 & $=$ & $\mathrm{m}^{3}$ \\
\hline & $1 \mathrm{gal}$ & $x$ & 3.785 & $=$ & $\mathrm{L}$ \\
\hline & 1 gal & $\times$ & $3.785 \times 10^{-3}$ & $=$ & $\mathrm{m}^{3}$ \\
\hline Temperature: & $-32^{\circ} \mathrm{F}$ & $\times$ & 0.556 & $=$ & ${ }^{\circ} \mathrm{C}$ \\
\hline \multirow[t]{4}{*}{ Energy: } & Btu & $x$ & 1055.1 & $=$ & joule \\
\hline & TBtu & $\times$ & $1055.1 \times 10^{-9}$ & $=$ & $\mathrm{kJ}$ \\
\hline & $\mathrm{Btu} / \mathrm{hr}$ & & 0.29307 & $=$ & watt \\
\hline & & X & & & \\
\hline Mass/Energy: & $\mathrm{lb} / \mathrm{Btu}$ & & 2.325 & $=$ & $\mathrm{kg} / \mathrm{kJ}$ \\
\hline
\end{tabular}




\section{SUBTASK 4.24 - FIELD EVALUATION OF NOVEL APPROACH FOR OBTAINING METAL EMISSION DATA}

\section{EXECUTIVE SUMMARY}

Over the past two decades, emissions of mercury, nonmercury metals, and acid gases from energy generation have become the focus of regulatory rule making. On February 16, 2012, the U.S. Environmental Protection Agency (EPA) promulgated the Mercury and Air Toxics Standards (MATS) to reduce mercury, nonmercury metals, and $\mathrm{HCl}$ emissions from coal-fired power plants (National Emission Standards for Hazardous Air Pollutants from Coal- and OilFired Electric Utility Steam Generating Units and Standards of Performance for Fossil-FuelFired Electric Utility, Industrial-Commercial-Institutional, and Small Industrial-CommercialInstitutional Steam Generating Units: Final Rule (Mercury and Air Toxics Standards [MATS]). 40 Code of Federal Regulations, Parts 60 and 63; Fed. Regist. 2012, 77 (32), 9304). The reference method for halogens is EPA Method (M) 26 or M26A. EPA M26 (nonisokinetic) and EPA M26A (isokinetic) are wet-chemistry, impinger-based methods that are designed to collect both acid gas and halogen gas species present in flue gas. M26A must be used if entrained water droplets are present in the flue gas. The reference method for mercury and nonmercury metal HAPs is EPA M29. There are a number of concerns regarding the use of EPA M26/26A and EPA M29 to meet the MATS requirements, including the following:

1. The methods are difficult to use, require highly trained personnel, and involve substantial preparation.

2. The methods utilize toxic chemicals that are a concern for safety, handling, shipping, and ultimate disposal.

3. A very high level of quality control is required, not only for sample analysis but for sample-collecting activities.

4. The detection limits for M29 may not be adequate in some cases to measure accurately at the existing unit limits established under MATS. Several of the new/reconstructed unit limits (e.g., As, Be, Co, and $\mathrm{Cd}$ for coal and new continental liquid oil units) are well below the capabilities of the method.

5. Inclusion of mercury in a M29 test creates a risk of contaminating the sample with manganese, because of the additional permanganate impinger that must be added to the sampling train.

As a potential alternative to EPA M29 and M26/26A, the Energy \& Environmental Research Center (EERC) developed a multielement sorbent trap (ME-ST) method with two separate sampling applications: one for metals (ME-ST-M) and one for halogens (ME-ST-H). The overall goal of this project was to evaluate the applicability and performance of the ME-ST method for measuring trace metal and $\mathrm{HCl}$ emissions at three North Dakota lignite-fired power plants.

A comparative study of the ME-ST-H method and EPA M26A was performed for the three test sites. At Plants 1 and 2, the $\mathrm{HCl}$ results showed no significant bias for the ME-ST-H method compared to M26A, and the precision of both methods was very good. At Plant 3, a significant bias was observed between the two methods for $\mathrm{HCl}$; EPA M26A measurements were below detection limits, while the ME-ST-H measurements were higher. This was most likely a result of 
water droplet formation in the wet stack. Wet stacks have been shown to be problematic for EPA M26A (Johnson, L.D. Stack Sampling Methods for Halogens and Halogen Acids. Presented at EPA-A\&WMA International Symposium on Measurement of Toxic and Related Air Pollutants, Research Triangle Park, NC, May 1996).

Although all three sites utilized North Dakota lignites, there were substantial differences in the metal emissions among the three sites. At Plant 1, Sb, As, Be, Cd, and Co emissions were below the detection limits for both methods. Hg was well above detection limits. For EPA M29 samples, there were significant background levels in the method blanks for $\mathrm{Cr}, \mathrm{Pb}, \mathrm{Mn}$, and $\mathrm{Ni}$. For the ME-ST-M method, high blank values were a problem for $\mathrm{Cd}, \mathrm{Cr}, \mathrm{Pb}, \mathrm{Mn}$, and $\mathrm{Ni}$. As a result, blanks were elevated for nine of the 11 metals ( $\mathrm{Hg}$ and Se were the exception), and modifications were made to the sorbent material for the ME-ST-M method to reduce the background blanks for the various trace metals.

At Plant 2, Sb, Be, and Cd were below the detection limits for EPA M29, but all trace metals of interest were above the detection limits for the ME-ST-M method. Although the sorbent material was modified, background levels were measurable, i.e., above detection limits, for eight of the 11 metals. For $\mathrm{Cr}, \mathrm{Mn}$, and $\mathrm{Ni}$, the background levels were such that the quality assurance/quality control limit (blank $\leq 30 \%$ of the sample value) was not met.

At Plant 3, all metals except Sb were above the detection limits for EPA M29. However, for $\mathrm{Cr}, \mathrm{Mn}$, and $\mathrm{Ni}$, the EPA M29 blanks were $>30 \%$ of the measured value, resulting in an invalid sample. Although the measured values were all above the detection limits of the ME-ST$\mathrm{M}$ method, after each of the trace metals was corrected for the blank, $\mathrm{Cd}, \mathrm{Cr}, \mathrm{Pb}$, and $\mathrm{Ni}$ were below the detection limits. The only trace metal having a blank value $>30 \%$ for the ME-ST-M method was Mn.

Although the three data sets obtained in this project are too few for a complete EPA M301 validation study, this procedure was used to statistically compare the ME-ST-M and ME-ST-H methods to the EPA reference methods, M29 and M26A, respectively. According to M301, a valid statistical comparison between the two trace metal-sampling methods for individual trace metals can only be made if both methods have results above the detection limit and the background (blank) concentrations are $\leq 30 \%$ of the measured value. The overall results showed that the ME-ST-M concentrations measured for $\mathrm{Hg}$, Se, $\mathrm{Sb}, \mathrm{As}, \mathrm{Cd}$, and Co that were above the MATS limit showed good agreement between EPA M29 and the ME-ST-M method, generally within $20 \%$.

Based on the results of these three field tests, the ME-ST-H method appears to be a good candidate as an alternative method to M26/26A. For the ME-ST-M method, additional research is still needed to explore possible longer sampling durations and/or selection of lowerbackground materials containing near-zero $\mathrm{Pb}, \mathrm{Ni}, \mathrm{Cr}$, and $\mathrm{Mn}$ before the ME-ST-M method can be considered as a potential alternative to M29.

This subtask was funded through the EERC-U.S. Department of Energy Joint Program on Research and Development for Fossil Energy-Related Resources Cooperative Agreement No. DE-FC26-08NT43291. Nonfederal funding was provided by the North Dakota Industrial Commission, Great River Energy, Minnesota Power, SaskPower, the Electric Power Research Institute, Montana-Dakota Utilities Co., Ohio Lumex, and Center for Air Toxic Metals ${ }^{\circledR}$ Affiliates. 


\section{SUBTASK 4.24 - FIELD EVALUATION OF NOVEL APPROACH FOR OBTAINING HALOGEN AND METAL EMISSION DATA}

\section{INTRODUCTION/BACKGROUND}

The adequacy of test methods for measuring hazardous air pollutants (HAPs) from stationary sources has become an increasingly important issue as the stack concentrations of pollutants that facilities are permitted to emit decrease. This report presents the results of field tests of a newly developed method for measuring emissions of two classes of HAPs: acid gases (specifically, hydrochloric acid $[\mathrm{HCl}]$ ) and trace metals.

Over the past two decades, emissions of mercury, nonmercury metals, and acid gases from energy generation have become the focus of regulatory rule making. On February 16, 2012, the U.S. Environmental Protection Agency (EPA) promulgated the Mercury and Air Toxics Standards (MATS) to reduce mercury, nonmercury metals, and $\mathrm{HCl}$ emissions from coal-fired power plants (1). The standard sets limits on mercury, nonmercury metals, and acid gas $(\mathrm{HCl})$ and for oil unit (hydrofluoric acid) emissions from new and existing coal- and oil-fired power plant units. After the compliance deadline (2015, or later if a waiver is given), existing coal- and oil-fired electric generating units (EGUs) will have to measure and report emissions and maintain emissions below specified limits. Newly constructed or reconstructed units will have to comply with new/reconstructed unit limits that are considerably lower than the limits for existing units.

Under MATS, EPA established National Emission Standards for Hazardous Air Pollutants (NESHAPs) from EGUs under Section 112(d) of the Clean Air Act and revised the New Source Performance Standards (NSPS) under Section 111(b). More specifically, the standard sets limits on mercury, nonmercury metals, and acid gas emissions from coal-fired plants. For the first time ever, EGUs will be regulated for $\mathrm{HCl}$, as shown in Table 1, and will have to measure and report $\mathrm{HCl}$ emissions. After challenges from several industrial petitioners, EPA proposed to reconsider a review of new technical information that focused on toxic air pollution limits for new power plants under MATS. Following the review, EPA proposed revised limits for new sources as shown in Table 2 (2). EPA also finalized changes to the NESHAPs for area sources (industrial, commercial, and institutional boilers) as well as the NESHAPs for major sources (industrial, commercial, and institutional boilers and process heaters), as shown in Table 3 (3).

Some coal-fired units may monitor sulfur dioxide (if they have a flue gas desulfurization [FGD] unit installed) as a surrogate for $\mathrm{HCl}$ emissions. MATS allows for several alternative standards for nonmercury metals:

1. Limits on metal emissions using particulate matter (PM) as a surrogate (Tables 1 and 2).

2. Individual nonmercury metals (shown in Table 4).

3. Total nonmercury metals (shown in Table 4). 
Table 1. Emission Limitations for Coal-Fired and Solid Oil-Derived Fuel-Fired EGUs

\begin{tabular}{|c|c|c|c|}
\hline Subcategory & Filterable PM & Hydrogen Chloride & Mercury \\
\hline $\begin{array}{l}\text { Existing - Unit Not } \\
\text { Designed for Low-Rank } \\
\text { Virgin Coal }\end{array}$ & $\begin{array}{l}3.0 \mathrm{E}-2 \mathrm{lb} / \mathrm{MMBtu} \\
(3.0 \mathrm{E}-1 \mathrm{lb} / \mathrm{MWh})\end{array}$ & $\begin{array}{l}2.0 \mathrm{E}-3 \mathrm{lb} / \mathrm{MMBtu} \\
(2.0 \mathrm{E}-2 \mathrm{lb} / \mathrm{MWh})\end{array}$ & $\begin{array}{c}1.2 \mathrm{lb} / \text { TBtu } \\
(1.3 \mathrm{E}-2 \mathrm{lb} / \mathrm{GWh})\end{array}$ \\
\hline $\begin{array}{l}\text { Existing - Unit Designed for } \\
\text { Low-Rank Virgin Coal }\end{array}$ & $\begin{array}{c}3.0 \mathrm{E}-2 \mathrm{lb} / \mathrm{MMBtu} \\
(3.0 \mathrm{E}-1 \mathrm{lb} / \mathrm{MWh})\end{array}$ & $\begin{array}{l}2.0 \mathrm{E}-3 \mathrm{lb} / \mathrm{MMBtu} \\
(2.0 \mathrm{E}-2 \mathrm{lb} / \mathrm{MWh})\end{array}$ & $\begin{array}{c}1.1 \mathrm{E}+1 \mathrm{lb} / \mathrm{TBtu} \\
(1.2 \mathrm{E}-1 \mathrm{lb} / \mathrm{GWh}) \\
4.0 \mathrm{E} 0 \mathrm{lb} / \mathrm{TBtu}^{\mathrm{a}} \\
\left(4.0 \mathrm{E}-2 \mathrm{lb} / \mathrm{GWh}^{\mathrm{a}}\right)\end{array}$ \\
\hline Existing $-\mathrm{IGCC}^{\mathrm{b}}$ & $\begin{array}{l}\text { 4.0E-2 lb/MMBtu } \\
(4.0 \mathrm{E}-1 \mathrm{lb} / \mathrm{MWh})\end{array}$ & $\begin{array}{l}5.0 \mathrm{E}-4 \mathrm{lb} / \mathrm{MMBtu} \\
(5.0 \mathrm{E}-3 \mathrm{lb} / \mathrm{MWh})\end{array}$ & $\begin{array}{c}2.5 \mathrm{lb} / \mathrm{TBtu} \\
(3.0 \mathrm{E}-2 \mathrm{lb} / \mathrm{GWh})\end{array}$ \\
\hline Existing - Solid Oil-Derived & $\begin{array}{l}\text { 8.0E-3 lb/MMBtu } \\
(9.0 \mathrm{E}-2 \mathrm{lb} / \mathrm{MWh})\end{array}$ & $\begin{array}{l}5.0 \mathrm{E}-3 \mathrm{lb} / \mathrm{MMBtu} \\
(8.0 \mathrm{E}-2 \mathrm{lb} / \mathrm{MWh})\end{array}$ & $\begin{array}{l}2.0 \mathrm{E}-1 \mathrm{lb} / \mathrm{TBtu} \\
(2.0 \mathrm{E}-3 \mathrm{lb} / \mathrm{GWh})\end{array}$ \\
\hline $\begin{array}{l}\text { New - Unit Not Designed } \\
\text { for Low-Rank Virgin Coal }\end{array}$ & 7.0E-3 lb/MWh & 4.0E-4 lb/MWh & $2.0 \mathrm{E}-4 \mathrm{lb} / \mathrm{GWh}$ \\
\hline $\begin{array}{l}\text { New - Unit Designed for } \\
\text { Low-Rank Virgin Coal }\end{array}$ & 7.0E-3 lb/MWh & 4.0E-4 lb/MWh & 4.0E-2 lb/GWh \\
\hline New - IGCC & $\begin{array}{l}7.0 \mathrm{E}-2 \mathrm{lb} / \mathrm{MWh}^{\mathrm{c}} \\
9.0 \mathrm{E}-2 \mathrm{lb} / \mathrm{MWh}^{\mathrm{f}}\end{array}$ & $2.0 \mathrm{E}-3 \mathrm{lb} / \mathrm{MWh}^{\mathrm{d}}$ & $3.0 \mathrm{E}-3 \mathrm{lb} / \mathrm{GWh}^{\mathrm{e}}$ \\
\hline New - Solid Oil-Derived & $2.0 \mathrm{E}-2 \mathrm{lb} / \mathrm{MWh}$ & 4.0E-4 lb/MWh & $2.0 \mathrm{E}-3 \mathrm{lb} / \mathrm{GWh}$ \\
\hline \multicolumn{4}{|c|}{$\begin{array}{l}\text { Note: } \mathrm{lb} / \mathrm{MMBtu}=\text { pounds pollutant per million British thermal units fuel input. } \mathrm{lb} / \mathrm{TBtu}=\text { pounds pollutant per trillion } \\
\text { British thermal units fuel input. } \mathrm{lb} / \mathrm{MWh}=\text { pounds pollutant per megawatt-hour electric output (gross). } \mathrm{lb} / \mathrm{GWh}= \\
\text { pounds pollutant per gigawatt-hour electric output (gross). } \\
{ }^{\mathrm{a}} \text { Beyond-the-floor limit. } \\
{ }^{\mathrm{b}} \text { Integrated gasification combined cycle. } \\
{ }^{\mathrm{c}} \text { Duct burners on syngas; based on permit levels in comments received. } \\
{ }^{\mathrm{d}} \text { Based on best-performing similar source. } \\
{ }^{\mathrm{e}} \text { Based on permit levels in comments received. } \\
{ }^{\mathrm{f}} \text { Duct burners on natural gas; based on permit levels in comments received. }\end{array}$} \\
\hline
\end{tabular}

Table 2. Emission Limitations for New Coal-Fired and Solid Oil-Derived Fuel-Fired EGUs

\begin{tabular}{l|c|c|c}
\hline Subcategory & Filterable PM & Hydrogen Chloride & Mercury \\
\hline $\begin{array}{c}\text { New - Unit Not Designed } \\
\text { for Designed for Low- }\end{array}$ & $9.0 \mathrm{E}-2 \mathrm{lb} / \mathrm{MWh}$ & $1.0 \mathrm{E}-2 \mathrm{lb} / \mathrm{MWh}^{\mathrm{a}}$ & $3.0 \mathrm{E}-3 \mathrm{lb} / \mathrm{GWh}$ \\
Rank Virgin Coal & & & \\
New - Unit Designed for & $9.0 \mathrm{E}-2 \mathrm{lb} / \mathrm{MWh}$ & $1.0 \mathrm{E}-2 \mathrm{lb} / \mathrm{MWh}^{\mathrm{a}}$ & $\mathrm{NR}$ \\
Low-Rank Virgin Coal & $7.0 \mathrm{E}-2 \mathrm{lb} / \mathrm{MWh}^{\mathrm{b}}$ & $2.0 \mathrm{E}-3 \mathrm{lb} / \mathrm{MWh}^{\mathrm{c}}$ & $3.0 \mathrm{E}-3 \mathrm{lb} / \mathrm{GWh}^{\mathrm{d}}$ \\
New - IGCC & $9.0 \mathrm{E}-2 \mathrm{lb} / \mathrm{MWh}^{\mathrm{e}}$ & $\mathrm{NR}$ & $\mathrm{NR}$ \\
& $3.0 \mathrm{E}-2 \mathrm{lb} / \mathrm{MWh}$ & $\mathrm{NR}$ & $\mathrm{N}$ \\
New - Solid Oil-Derived &
\end{tabular}

Note: $\mathrm{lb} / \mathrm{MWh}=$ pounds pollutant per megawatt-hour electric output (gross). $\mathrm{lb} / \mathrm{GWh}=$ pounds pollutant per gigawatt-hour electric output (gross). $\mathrm{NR}=$ limit not revised.

${ }^{\mathrm{a}}$ Beyond-the-floor value.

${ }^{\mathrm{b}}$ Duct burners on syngas; based on permit levels in comments received.

${ }^{\mathrm{c}}$ Based on best-performing similar source.

${ }^{\mathrm{d}}$ Based on permit levels in comments received.

${ }^{\mathrm{e}}$ Duct burners on natural gas; based on permit levels in comments received. 
Table 3. Emission Limits for Major Industrial Boiler and Process Heaters

[b/MMBtu heat input basis unless noted; alternative ouput based limits are not shown in the summary table below]

\begin{tabular}{|c|c|c|c|c|c|}
\hline Subcategory & $\begin{array}{c}\text { Filterable PM } \\
\text { (or total S\$lected } \\
\text { metals) } \\
\text { (lb per MikBtu of } \\
\text { heat input) }\end{array}$ & $\begin{array}{l}\mathrm{HCl} \\
\text { (b per } \\
\text { MMBtu of } \\
\text { heat } \\
\text { input) }\end{array}$ & $\begin{array}{l}\text { Mercury } \\
\text { (lb per } \\
\text { MiMBtu of } \\
\text { heat } \\
\text { input) }\end{array}$ & $\begin{array}{c}C O \\
\text { (ppm }_{\text {oxygen) }}{ }^{\mathrm{a}}\end{array}$ & $\begin{array}{l}\text { Alternate CO } \\
\text { CEMS limit, } \\
\text { (ppm } \odot 3 \% \\
\text { oxygen) }{ }^{b}\end{array}$ \\
\hline Existing-Coal Stoker ...... & $0.040(5.3 E-05) \ldots$ & 0.022 & 5.7E-06 & 160 & 340 \\
\hline 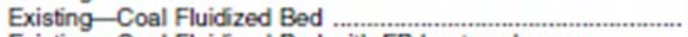 & $0.040(5.3 E-05) \ldots$ & 0.022 & 5.7E-06 & 130 & 230 \\
\hline Existing-Coal Fluidized Bed with FB heat exchanger .. & $0.040(5.3 E-05) \ldots$ & 0.022 & 5.7E-06 & 140 & 150 \\
\hline 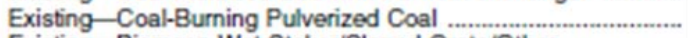 & $0.040(5.3 E-05) \ldots$ & 0.022 & 5.7E-06 & 130 & 320 \\
\hline Existing-Biomass Wet Stoker/Sloped Grate/Other .......... & $0.037(2.4 E-04) \ldots$ & 0.022 & 5.7E-06 & 1,500 & 720 \\
\hline Existing-Biomass Kiln-Dried Stoker/Sloped Grate/Other . & $0.32(4.0 \mathrm{E}-03) \ldots . .$. & 0.022 & 5.7E-06 & 460 & ND \\
\hline 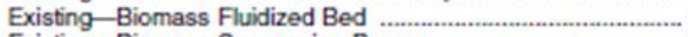 & $0.11(1.2 E-03) \ldots$ & 0.022 & 5.7E-06 & 470 & 310 \\
\hline Existing-Biomass Suspension Bumer ............ & $0.051(6.5 E-03) \ldots$ & 0.022 & 5.7E-06 & 2,400 & $\cdot 2,000$ \\
\hline Existing-Biomass Dutch Ovens/Pile Burners . & $0.28(2.0 E-03)$ & 0.022 & 5.7E-06 & 770 & $\circ 520$ \\
\hline 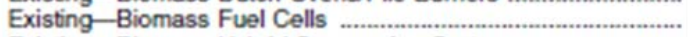 & $0.020(5.8 E-03) \ldots$ & 0.022 & 5.7E-06 & 1,100 & ND \\
\hline Existing-Biomass Hybrid Suspension Grate ... & $0.44(4.5 E-0.4)$ & 0.022 & 5.7E-06 & 2,800 & 900 \\
\hline 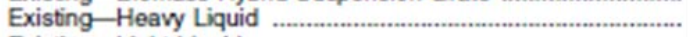 & $0.062(2.0 E-04) \ldots$ & 0.0011 & $2.0 \mathrm{E}-06$ & 130 & ND \\
\hline Existing-Light Liquid ... & $0.0079(6.2 \mathrm{E}-05)$ & 0.0011 & $2.0 \mathrm{E}-06$ & 130 & ND \\
\hline Existing-non-Continental Liquid & $0.27(8.6 E-04)$ & 0.0011 & $2.0 E-06$ & 130 & ND \\
\hline Existing-Gas 2 (Other Process Gases) & $0.0067(2.1 \mathrm{E}-04)$ & 0.0017 & $7.9 \mathrm{E}-06$ & 130 & ND \\
\hline 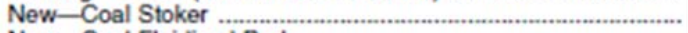 & $0.0011(2.3 E-05)$ & 0.022 & 8.0E-07 & 130 & 340 \\
\hline New-Coal Fluidized Bed & $0.0011(2.3 E-05)$ & 0.022 & $8.0 \mathrm{E}-07$ & 130 & 230 \\
\hline New-Coal Fluidized Bed with FB Heat Exchanger . & $0.0011(2.3 E-05)$ & 0.022 & 8.0E-07 & 140 & 150 \\
\hline New-Coal-Burning Pulverized Coal ........................... & $0.0011(2.3 E-05)$ & 0.022 & $8.0 \mathrm{E}-07$ & 130 & 320 \\
\hline New-Biomass Wet Stoker/Sloped Grate/Other ...... & $0.030(2.6 E-05) \ldots$ & 0.022 & 8.0E-07 & 620 & 390 \\
\hline New-Biomass Kiln-Dried Stoker/Sloped Grate/Other ... & $0.030(4.0 E-03) \ldots$ & 0.022 & 8.0E-07 & 460 & ND \\
\hline 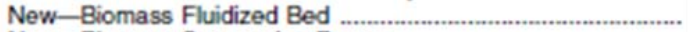 & $0.0098(8.3 E-05)$ & 0.022 & 8.0E-07 & 230 & 310 \\
\hline 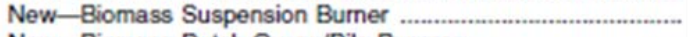 & $0.030(6.5 E-03) \ldots$ & 0.022 & 8.0E-07 & 2,400 & ${ }^{\circ} 2,000$ \\
\hline New-Biomass Dutch Ovens/Pile Burners ... & $0.0032(3.9 E-05)$ & 0.022 & 8.0E-07 & 330 & $\circ 520$ \\
\hline New-Biomass Fuel Cells ............................. & $0.020(2.9 E-05) \ldots$ & 0.022 & 8.0E-07 & 910 & ND \\
\hline New-Biomass Hybrid Suspension Grate. & $0.026(4.4 E-04)$ & 0.022 & 8.0E-07 & 1,100 & 900 \\
\hline 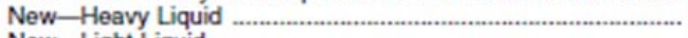 & $0.013(7.5 E-05)$ & 4.4E-04 & $4.8 \mathrm{E}-07$ & 130 & ND \\
\hline 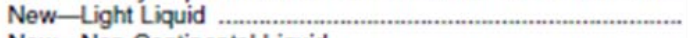 & $0.0011(2.9 E-05)$ & 4.4E-04 & $4.8 \mathrm{E}-07$ & 130 & ND \\
\hline New-Non-Continental Liquid ...................... & $0.023(8.6 E-04) \ldots$ & 4.4E-0.4 & 4.8E-07 & 130 & ND \\
\hline New-Gas 2 (Other Process Gases) ........ & $0.0067(2.1 \mathrm{E}-04)$ & 0.0017 & $7.9 \mathrm{E}-06$ & 130 & ND \\
\hline
\end{tabular}

The nonmercury metals that are included in the second and third alternative standard are antimony ( $\mathrm{Sb})$, arsenic (As), beryllium (Be), cadmium $(\mathrm{Cd})$, chromium $(\mathrm{Cr})$, cobalt $(\mathrm{Co})$, lead $(\mathrm{Pb})$, manganese $(\mathrm{Mn})$, nickel $(\mathrm{Ni})$, and selenium $(\mathrm{Se})$.

Owners and operators of EGUs may select from any of the three alternatives but must demonstrate compliance with required limits either using continuous emission monitor (CEM) systems or frequent periodic sampling using EPA-approved reference methods. For units that elect to use CEMs, the CEMs must be certified and validated using EPA-approved reference sampling methods. For coal-fired units that elect to comply with the total or individual nonmercury metal emissions, the unit must conduct metal emission testing every 3 months using EPA Method (M) 29. Likewise, units that do not qualify for $\mathrm{SO}_{2}$ surrogacy and elect not to use an $\mathrm{HCl} \mathrm{CEM} \mathrm{must} \mathrm{conduct} \mathrm{HCl}$ emission testing every 3 months using EPA M26 or M26A.

As a possible alternative to EPA M29 and M26A, the Energy \& Environmental Research Center (EERC) has developed a novel multielement sorbent trap (ME-ST) method to be used to sample for trace elements and/or halogens (4). This project was undertaken to compare the MEST method with the EPA reference methods to determine if the ME-ST method could produce comparable data. 
Table 4. Alternate Emission Limitations for Existing Coal- and Oil-Fired EGUs

\begin{tabular}{|c|c|c|c|c|c|}
\hline Subcategory/Pollutant & Coal-Fired EGUs & IGCC & $\begin{array}{l}\text { Liquid Oil, } \\
\text { Continental }\end{array}$ & $\begin{array}{c}\text { Liquid Oil, } \\
\text { Noncontinental }\end{array}$ & Solid Oil-Derived \\
\hline$\overline{\mathrm{SO}_{2}}$ & $\begin{array}{c}2.0 \mathrm{E}-1 \mathrm{lb} / \mathrm{MMBtu} \\
(1.5 \mathrm{lb} / \mathrm{MWh})\end{array}$ & $\mathrm{NA}^{\mathrm{a}}$ & NA & NA & $\begin{array}{c}\text { 3.0E-1 lb/MMBtu } \\
(2.0 \mathrm{lb} / \mathrm{MWh})\end{array}$ \\
\hline $\begin{array}{l}\text { Total Nonmercury } \\
\text { Metals }\end{array}$ & $\begin{array}{l}5.0 \mathrm{E}-5 \mathrm{lb} / \mathrm{MMBtu} \\
(5.0 \mathrm{E}-1 \mathrm{lb} / \mathrm{GWh})\end{array}$ & $\begin{array}{c}6.0 \mathrm{E}-5 \mathrm{lb} / \mathrm{MMBtu} \\
(5.0 \mathrm{E}-1 \mathrm{lb} / \mathrm{GWh})\end{array}$ & $\begin{array}{l}8.0 \mathrm{E}-4 \mathrm{lb} / \mathrm{MMBtu} \\
(8.0 \mathrm{E}-3 \mathrm{lb} / \mathrm{MWh})^{\mathrm{b}}\end{array}$ & $\begin{array}{l}\text { 6.0E-4 lb/MMBtu } \\
(7.0 \mathrm{E}-3 \mathrm{lb} \cdot \mathrm{MWh})^{\mathrm{b}}\end{array}$ & $\begin{array}{l}4.0 \mathrm{E}-5 \mathrm{lb} / \mathrm{MMBtu} \\
(6.0 \mathrm{E}-1 \mathrm{lb} / \mathrm{GWh})\end{array}$ \\
\hline Antimony, $\mathrm{Sb}$ & $\begin{array}{c}8.0 \mathrm{E}-1 \mathrm{lb} / \mathrm{TBtu} \\
(8.0 \mathrm{E}-3 \mathrm{lb} / \mathrm{GWh})\end{array}$ & $\begin{array}{c}1.4 \mathrm{lb} / \mathrm{TBtu} \\
(2.0 \mathrm{E}-2 \mathrm{lb} / \mathrm{GWh})\end{array}$ & $1.3 \mathrm{E}+1 \mathrm{lb} / \mathrm{TBtu}$ & $\begin{array}{c}2.2 \mathrm{E} 0 \mathrm{lb} / \mathrm{TBtu} \\
(2.0 \mathrm{E}-2 \mathrm{lb} / \mathrm{GWh})\end{array}$ & $\begin{array}{c}8.0 \mathrm{E}-1 \mathrm{lb} / \mathrm{TBtu} \\
(8.0 \mathrm{E}-3 \mathrm{lb} / \mathrm{GWh})\end{array}$ \\
\hline Arsenic, As & $\begin{array}{c}1.1 \mathrm{lb} / \mathrm{TBtu} \\
(2.0 \mathrm{E}-2 \mathrm{lb} / \mathrm{GWh})\end{array}$ & $\begin{array}{c}1.5 \mathrm{lb} / \mathrm{TBtu} \\
(2.0 \mathrm{E}-2 \mathrm{lb} / \mathrm{GWh})\end{array}$ & $\begin{array}{c}(2.0 \mathrm{E}-1 \mathrm{lb} / \mathrm{GWh}) \\
2.8 \mathrm{lb} / \mathrm{TBtu}\end{array}$ & $\begin{array}{c}4.3 \mathrm{E} 0 \mathrm{lb} / \mathrm{TBtu} \\
(8.0 \mathrm{E}-2 \mathrm{lb} / \mathrm{GWh})\end{array}$ & $\begin{array}{l}3.0 \mathrm{E}-1 \mathrm{lb} / \mathrm{TBtu} \\
(5.0 \mathrm{E}-3 \mathrm{lb} / \mathrm{GWh})\end{array}$ \\
\hline Beryllium, Be & $\begin{array}{c}2.0 \mathrm{E}-1 \mathrm{lb} / \mathrm{TBtu} \\
(2.0 \mathrm{E}-3 \mathrm{lb} / \mathrm{GWh})\end{array}$ & $\begin{array}{l}1.0 \mathrm{E}-1 \mathrm{lb} / \mathrm{TBtu} \\
(1.0 \mathrm{E}-3 \mathrm{lb} / \mathrm{GWh})\end{array}$ & $\begin{array}{c}(3.0 \mathrm{E}-2 \mathrm{lb} / \mathrm{GWh}) \\
2.0 \mathrm{E}-1 \mathrm{lb} / \mathrm{TBtu}\end{array}$ & $\begin{array}{c}6.0 \mathrm{E}-1 \mathrm{lb} / \mathrm{TBtu} \\
(3.0 \mathrm{E}-3 \mathrm{lb} / \mathrm{GWh})\end{array}$ & $\begin{array}{c}6.0 \mathrm{E}-2 \mathrm{lb} / \mathrm{TBtu} \\
(6.0 \mathrm{E}-4 \mathrm{lb} / \mathrm{GWh})\end{array}$ \\
\hline Cadmium, $\mathrm{Cd}$ & $\begin{array}{c}3.0 \mathrm{E}-1 \mathrm{lb} / \mathrm{TBtu} \\
(3.0 \mathrm{E}-3 \mathrm{lb} / \mathrm{GWh})\end{array}$ & $\begin{array}{c}1.5 \mathrm{E}-1 \mathrm{lb} / \mathrm{TBtu} \\
(2.0 \mathrm{E}-3 \mathrm{lb} / \mathrm{GWh})\end{array}$ & $\begin{array}{c}(2.0 \mathrm{E}-3 \mathrm{lb} / \mathrm{GWh}) \\
3.0 \mathrm{E}-1 \mathrm{lb} / \mathrm{TBtu}\end{array}$ & $\begin{array}{c}3.0 \mathrm{E}-1 \mathrm{lb} / \mathrm{TBtu} \\
(3.0 \mathrm{E}-3 \mathrm{lb} / \mathrm{GWh})\end{array}$ & $\begin{array}{c}3.0 \mathrm{E}-1 \mathrm{lb} / \mathrm{TBtu} \\
(4.0 \mathrm{E}-3 \mathrm{lb} / \mathrm{GWh})\end{array}$ \\
\hline Chromium, $\mathrm{Cr}$ & $\begin{array}{c}2.8 \mathrm{lb} / \mathrm{TBtu} \\
(3.0 \mathrm{E}-2 \mathrm{lb} / \mathrm{GWh})\end{array}$ & $\begin{array}{c}2.9 \mathrm{lb} / \mathrm{TBtu} \\
(3.0 \mathrm{E}-2 \mathrm{lb} / \mathrm{GWh})\end{array}$ & $\begin{array}{c}(2.0 \mathrm{E}-3 \mathrm{lb} / \mathrm{GWh}) \\
5.5 \mathrm{lb} / \mathrm{TBtu}\end{array}$ & $\begin{array}{c}3.1 \mathrm{E}+1 \mathrm{lb} / \mathrm{TBtu} \\
(3.0 \mathrm{E}-1 \mathrm{lb} / \mathrm{GWh})\end{array}$ & $\begin{array}{l}8.0 \mathrm{E}-1 \mathrm{lb} / \mathrm{TBtu} \\
(2.0 \mathrm{E}-2 \mathrm{lb} / \mathrm{GWh})\end{array}$ \\
\hline Cobalt, Co & $\begin{array}{c}8.0 \mathrm{E}-1 \mathrm{lb} / \mathrm{TBtu} \\
(8.0 \mathrm{E}-3 \mathrm{lb} / \mathrm{GWh})\end{array}$ & $\begin{array}{c}1.2 \mathrm{lb} / \mathrm{TBtu} \\
(2.0 \mathrm{E}-2 \mathrm{lb} / \mathrm{GWh})\end{array}$ & $\begin{array}{c}(6.0 \mathrm{E}-2 \mathrm{lb} / \mathrm{GWh}) \\
2.1 \mathrm{E}+1 \mathrm{lb} / \mathrm{TBtu}\end{array}$ & $\begin{array}{l}1.1 \mathrm{E}+2 \mathrm{lb} / \mathrm{TBtu} \\
(1.4 \mathrm{E} 0 \mathrm{lb} / \mathrm{GWh})\end{array}$ & $\begin{array}{c}1.1 \mathrm{lb} / \mathrm{TBtu} \\
(2.0 \mathrm{E}-2 \mathrm{lb} / \mathrm{GWh})\end{array}$ \\
\hline Lead, $\mathrm{Pb}$ & $\begin{array}{c}1.2 \mathrm{lb} / \mathrm{TBtu} \\
(2.0 \mathrm{E}-2 \mathrm{lb} / \mathrm{GWh})\end{array}$ & $\begin{array}{c}1.9 \mathrm{E}+2 \mathrm{lb} / \mathrm{MMBtu} \\
(1.8 \mathrm{lb} / \mathrm{MWh})\end{array}$ & $\begin{array}{c}(3.0 \mathrm{E}-1 \mathrm{lb} / \mathrm{GWh}) \\
8.1 \mathrm{lb} / \mathrm{TBtu}\end{array}$ & $\begin{array}{c}4.9 \mathrm{E} 0 \mathrm{lb} / \mathrm{TBtu} \\
(8.0 \mathrm{E}-2 \mathrm{lb} / \mathrm{GWh})\end{array}$ & $\begin{array}{c}8.0 \mathrm{E}-1 \mathrm{lb} / \mathrm{TBtu} \\
(2.0 \mathrm{E}-2 \mathrm{lb} / \mathrm{GWh})\end{array}$ \\
\hline Manganese, Mn & $\begin{array}{c}4.0 \mathrm{lb} / \mathrm{TBtu} \\
(5.0 \mathrm{E}-2 \mathrm{lb} / \mathrm{GWh})\end{array}$ & $\begin{array}{c}2.5 \mathrm{lb} / \mathrm{TBtu} \\
(3.0 \mathrm{E}-2 \mathrm{lb} / \mathrm{GWh})\end{array}$ & $\begin{array}{c}(8.0 \mathrm{E}-2 \mathrm{lb} / \mathrm{GWh}) \\
2.2 \mathrm{E}+1 \mathrm{lb} / \mathrm{TBtu}\end{array}$ & $\begin{array}{c}2.0 \mathrm{E}+1 \mathrm{lb} / \mathrm{TBtu} \\
(3.0 \mathrm{E}-1 \mathrm{lb} / \mathrm{GWh})\end{array}$ & $\begin{array}{c}2.3 \mathrm{lb} / \mathrm{TBtu} \\
(4.0 \mathrm{E}-2 \mathrm{lb} / \mathrm{GWh})\end{array}$ \\
\hline Mercury, $\mathrm{Hg}$ & NA & NA & $\begin{array}{c}(3.0 \mathrm{E}-1 \mathrm{lb} / \mathrm{GWh}) \\
2.0 \mathrm{E}-1 \mathrm{lb} / \mathrm{TBtu}\end{array}$ & $\begin{array}{c}4.0 \mathrm{E}-2 \mathrm{lb} / \mathrm{TBtu} \\
(4.0 \mathrm{E}-4 \mathrm{lb} / \mathrm{GWh})\end{array}$ & NA \\
\hline Nickel, Ni & $\begin{array}{c}3.5 \mathrm{lb} / \mathrm{TBtu} \\
(4.0 \mathrm{E}-2 \mathrm{lb} / \mathrm{GWh})\end{array}$ & $\begin{array}{c}6.5 \mathrm{lb} / \mathrm{TBtu} \\
(7.0 \mathrm{E}-2 \mathrm{lb} / \mathrm{GWh})\end{array}$ & $\begin{array}{c}(2.0 \mathrm{E}-3 \mathrm{lb} / \mathrm{GWh}) \\
1.1 \mathrm{E}+2 \mathrm{lb} / \mathrm{TBtu}\end{array}$ & $\begin{array}{l}4.7 \mathrm{E}+2 \mathrm{lb} / \mathrm{TBtu} \\
(4.1 \mathrm{E} 0 \mathrm{lb} / \mathrm{GWh})\end{array}$ & $\begin{array}{c}9.0 \mathrm{lb} / \mathrm{TBtu} \\
(2.0 \mathrm{E}-1 \mathrm{lb} / \mathrm{GWh})\end{array}$ \\
\hline Selenium, Se & $\begin{array}{c}5.0 \mathrm{lb} / \mathrm{TBtu} \\
(6.0 \mathrm{E}-2 \mathrm{lb} / \mathrm{GWh})\end{array}$ & $\begin{array}{c}2.2 \mathrm{E}+1 \mathrm{lb} / \mathrm{TBtu} \\
(3.0 \mathrm{E}-1 \mathrm{lb} / \mathrm{GWh})\end{array}$ & $\begin{array}{c}(1.1 \mathrm{lb} / \mathrm{GWh}) \\
3.3 \mathrm{lb} / \mathrm{TBtu} \\
(4.0 \mathrm{E}-2 \mathrm{lb} / \mathrm{GWh})\end{array}$ & $\begin{array}{c}9.8 \mathrm{E} 0 \mathrm{lb} / \mathrm{TBtu} \\
(2.0 \mathrm{E}-1 \mathrm{lb} / \mathrm{GWh})\end{array}$ & $\begin{array}{c}1.2 \mathrm{lb} / \mathrm{TBtu} \\
(2.0 \mathrm{E}-2 \mathrm{lb} / \mathrm{GWh})\end{array}$ \\
\hline
\end{tabular}

\footnotetext{
${ }^{\mathrm{a}}$ Not applicable
} 


\section{PROJECT GOALS AND OBJECTIVES}

The overall goal of this project was to evaluate the applicability and performance of the ME-ST method for metals (ME-ST-M) and for HCl (ME-ST-H) to accurately measure stack emissions at three North Dakota lignite-fired power plants. Specific objectives of the project were as follows:

1. To evaluate the applicability and performance of the ME-ST-M and ME-ST-H methods in a full-scale field test situation.

2. To improve on the ME-ST methods.

3. To evaluate the equivalency of the two ME-ST methods with the corresponding EPA reference methods.

4. To provide metal and halogen stack emission data that can be used by North Dakota coal-fired power plants to identify strategies to comply with the MATS.

The ultimate goal of the EERC effort, which is ongoing, is to develop, publish, and obtain regulatory acceptance of sorbent trap-based multielement- and/or total halogen-sampling methods, complete with laboratory analysis procedures. The methods should achieve detection limits equivalent to or lower than EPA M29 and M26A and low enough to accurately measure the target HAPs at the MATS limits shown in Tables 5 and 6 for both existing and new/reconstructed plants.

Table 5. MATS Limits and Corresponding Flue Gas Concentrations for HCI Emissions from Coal-Fired Power Plants

\begin{tabular}{|c|c|c|c|}
\hline MATS Sources & MATS Limits $(1,2)$ & $\begin{array}{c}\text { Approx. Limits, } \\
\operatorname{ppm}(\mathrm{v}) \text { dry at } 3 \% \mathrm{O}_{2}\end{array}$ & $\begin{array}{l}\text { Approx. Limits, } \\
\mu \mathrm{g} / \mathrm{dNm}^{3} \text { at } 3 \% \mathrm{O}_{2}\end{array}$ \\
\hline \multicolumn{4}{|l|}{ Existing Units } \\
\hline $\begin{array}{l}\text { Unit Not Designed for Low- } \\
\text { Rank Virgin Coal } \\
\left(>8300 \mathrm{Btu} / \mathrm{lb}^{\mathrm{a}}\right)\end{array}$ & $\begin{array}{c}2.0 \times 10^{-3} \mathrm{lb} / \mathrm{MMBtu} \\
2.0 \times 10^{-2} \mathrm{lb} / \mathrm{MWh}\end{array}$ & $\sim 1.9$ & 2900 \\
\hline $\begin{array}{l}\text { Unit Designed for Low-Rank } \\
\text { Virgin Coal }\left(<8300 \mathrm{Btu} / \mathrm{lb}^{\mathrm{b}}\right)\end{array}$ & $\begin{array}{c}2.0 \times 10^{-3} \mathrm{lb} / \mathrm{MMBtu} \\
2.0 \times 10^{-2} \mathrm{lb} / \mathrm{MWh}\end{array}$ & $\sim 1.8$ & 2700 \\
\hline \multicolumn{4}{|l|}{ New or Reconstructed Units } \\
\hline $\begin{array}{l}\text { Unit Not Designed for Low- } \\
\text { Rank Virgin Coal } \\
\left(>8300 \mathrm{Btu} / \mathrm{lb}^{\mathrm{a}}\right)\end{array}$ & $1.0 \times 10^{-2} \mathrm{lb} / \mathrm{MWh}$ & $\sim 0.9$ & 1450 \\
\hline $\begin{array}{l}\text { Designed for Low-Rank } \\
\text { Virgin Coal }\left(<8300 \mathrm{Btu} / \mathrm{lb}^{\mathrm{b}}\right)\end{array}$ & $1.0 \times 10^{-2} \mathrm{lb} / \mathrm{MWh}$ & $\sim 0.9$ & 1350 \\
\hline
\end{tabular}


Table 6. MATS Limits and Corresponding Flue Gas Concentrations for Metal Emissions for Coal-Fired Power Plant Units

\begin{tabular}{|c|c|c|c|c|c|c|}
\hline \multirow[b]{2}{*}{ Metal } & \multicolumn{3}{|c|}{ Existing Units } & \multicolumn{3}{|c|}{ New or Reconstructed Units } \\
\hline & $\begin{array}{l}\text { MATS Limits } \\
(1,2)\end{array}$ & $\begin{array}{l}\text { Approx. } \\
\text { Limits, }{ }^{\text {a }} \\
\text { ppb(v) dry } \\
\text { at } 3 \% \mathrm{O}_{2}\end{array}$ & $\begin{array}{l}\text { Approx. } \\
\text { Limits, }{ }^{\text {a }} \\
\mu \mathrm{g} / \mathrm{dN}^{3} \\
\text { at } 3 \% \mathrm{O}_{2} \\
\end{array}$ & $\begin{array}{l}\text { MATS Limits } \\
(1,2)\end{array}$ & $\begin{array}{l}\text { Approx. } \\
\text { Limits, }{ }^{\text {a }} \\
\text { ppb(v) dry } \\
\text { at } 3 \% \mathrm{O}_{2}\end{array}$ & $\begin{array}{l}\text { Approx. } \\
\text { Limits, }{ }^{\text {a }} \\
\mu \mathrm{g} / \mathrm{dN}^{3} \\
\text { at } 3 \% \mathrm{O}_{2}\end{array}$ \\
\hline $\begin{array}{l}\text { Total Non-Hg } \\
\text { Metals }\end{array}$ & $\begin{array}{c}50 \mathrm{lb} / \mathrm{TBtu} \\
0.50 \mathrm{lb} / \mathrm{GWh}\end{array}$ & - & 66.96 & $0.06 \mathrm{lb} / \mathrm{GWh}$ & - & 7.96 \\
\hline Antimony, $\mathrm{Sb}$ & $\begin{array}{c}0.80 \mathrm{lb} / \mathrm{TBtu} \\
0.0080 \\
\mathrm{lb} / \mathrm{GWh}\end{array}$ & 0.214 & 1.08 & $0.008 \mathrm{lb} / \mathrm{GWh}$ & 0.214 & 1.08 \\
\hline Arsenic, As & $\begin{array}{c}1.1 \mathrm{lb} / \text { TBtu } \\
0.020 \mathrm{lb} / \mathrm{GWh}\end{array}$ & 0.400 & 2.65 & $0.003 \mathrm{lb} / \mathrm{GWh}$ & 0.128 & 0.40 \\
\hline Beryllium, Be & $\begin{array}{c}0.20 \mathrm{lb} / \mathrm{TBtu} \\
0.0020 \\
\mathrm{lb} / \mathrm{GWh}\end{array}$ & 0.723 & 0.27 & $\begin{array}{l}0.0006 \\
\mathrm{lb} / \mathrm{GWh}\end{array}$ & 0.210 & 0.07 \\
\hline Cadmium, $\mathrm{Cd}$ & $\begin{array}{c}0.30 \mathrm{lb} / \mathrm{TBtu} \\
0.0030 \\
\mathrm{lb} / \mathrm{GWh}\end{array}$ & 0.087 & 0.41 & $\begin{array}{c}0.0004 \\
\mathrm{lb} / \mathrm{GWh}\end{array}$ & 0.011 & 0.05 \\
\hline Chromium, $\mathrm{Cr}$ & $\begin{array}{c}2.8 \mathrm{lb} / \text { TBtu } \\
0.030 \mathrm{lb} / \mathrm{GWh}\end{array}$ & 1.842 & 3.99 & $0.007 \mathrm{lb} / \mathrm{GWh}$ & 0.430 & 0.93 \\
\hline Cobalt, Co & $\begin{array}{c}0.80 \mathrm{lb} / \mathrm{TBtu} \\
0.0080 \\
\mathrm{lb} / \mathrm{GWh}\end{array}$ & 0.442 & 1.08 & $0.002 \mathrm{lb} / \mathrm{GWh}$ & 0.108 & 0.27 \\
\hline Lead, $\mathrm{Pb}$ & $\begin{array}{c}1.2 \mathrm{lb} / \text { TBtu } \\
0.020 \mathrm{lb} / \mathrm{GWh}\end{array}$ & 0.310 & 2.65 & $0.02 \mathrm{lb} / \mathrm{GWh}$ & 0.310 & 2.65 \\
\hline Manganese, Mn & $\begin{array}{c}4.0 \mathrm{lb} / \text { TBtu } \\
0.050 \mathrm{lb} / \mathrm{GWh}\end{array}$ & 2.910 & 6.63 & $0.004 \mathrm{lb} / \mathrm{GWh}$ & 0.232 & 0.53 \\
\hline $\begin{array}{l}\text { Mercury, } \mathrm{Hg} \\
\left(^{(l o w-r a n k ~ c o a l)}\right)^{b}\end{array}$ & $\begin{array}{c}4.0 \mathrm{lb} / \mathrm{Tbtu} \\
0.040 \mathrm{lb} / \mathrm{GWh}\end{array}$ & 0.650 & 5.42 & $0.040 \mathrm{lb} / \mathrm{GWh}$ & 0.650 & 5.42 \\
\hline $\begin{array}{l}\text { Mercury, } \mathrm{Hg} \\
\text { (non-low-rank coal) }^{\mathrm{c}}\end{array}$ & $\begin{array}{c}1.2 \mathrm{lb} / \text { Tbtu } \\
0.013 \mathrm{lb} / \mathrm{GWh}\end{array}$ & 0.200 & 1.63 & $0.003 \mathrm{lb} / \mathrm{GWh}$ & 0.050 & 0.38 \\
\hline Nickel, Ni & $\begin{array}{c}3.5 \mathrm{lb} / \text { TBtu } \\
0.040 \mathrm{lb} / \mathrm{GWh}\end{array}$ & 2.066 & 5.31 & $0.040 \mathrm{lb} / \mathrm{GWh}$ & 2.066 & 5.31 \\
\hline Selenium, Se & $\begin{array}{c}5.0 \mathrm{lb} / \mathrm{TBtu} \\
0.060 \mathrm{lb} / \mathrm{GWh}\end{array}$ & 2.426 & 7.96 & $0.05 \mathrm{lb} / \mathrm{GWh}$ & 2.030 & 6.67 \\
\hline
\end{tabular}

\footnotetext{
${ }^{a}$ Calculated values based on North Dakota lignite coal and a heat rate of $10,800 \mathrm{Btu} / \mathrm{kWh}$.

${ }^{\mathrm{b}}$ Low-rank coal is $<8300 \mathrm{Btu} / \mathrm{lb}$.

${ }^{c}$ Non-low-rank coal is $>8300 \mathrm{Btu} / \mathrm{lb}$.
} 
In order to achieve the goals and objective of this project, the following activities were performed:

1. Stack sampling was conducted at three power plant units firing lignite coal. Sampling included EPA M29, EPA M26A, the ME-ST-M method, and the ME-ST-H method.

2. Coal samples were collected, ultimate-proximate analysis was performed, and each coal sample was analyzed for trace metals and halogens.

3. Quality assurance/quality control $(\mathrm{QA} / \mathrm{QC})$ measures were defined, and the data collected were evaluated based on those measures.

4. The results of ME-ST-M sampling at each site were compared to EPA M29 data, and the results of ME-ST-H sampling were compared to EPA M26A data.

\section{EXPERIMENTAL METHODS AND SAMPLING APPROACH}

In this study, novel sorbent tube methods developed by the EERC were compared to the results of the standard EPA source test methods. This section describes the sampling procedures and analytical methods used in the test program.

\section{EPA Standard Sampling Methods}

\section{Halogens (EPA M26/26A)}

The reference method for halogens is EPA M26/26A (5) (details of this method can be found at www.epa.gov/ttn/emc/promgate/m-26a.pdf). M26 (nonisokinetic) and M26A (isokinetic) are wet-chemistry, impinger-based methods. M26A must be used at units with suspended water droplets (wet stacks). In addition to $\mathrm{HCl}, \mathrm{M} 26 / 26 \mathrm{~A}$ can be used to measure $\mathrm{HBr}, \mathrm{HF}, \mathrm{Cl}_{2}$, and $\mathrm{Br}_{2}$ emissions. Although this method claims to speciate $\mathrm{Cl}_{2}$ and $\mathrm{HCl}$, research has shown that the speciation can be biased (6). Figure 1 displays a schematic of M26A.

The published method detection limits (MDLs) for M26/26A are 0.01 and 0.04 dry $\operatorname{ppm}(\mathrm{v})$, respectively, assuming a 1-dry-standard-cubic-meter sample. These detection limits do not take into account the uncertainty and errors associated with sample collection and possible biases. It should be recognized that these methods have a potentially high bias for $\mathrm{HCl}$ in the presence of volatile materials such as chlorine dioxide and ammonium chloride. There is also a potential measurable low bias for $\mathrm{HCl}$ under 20 dry ppm(v), caused by moisture in the flue gas (7). This bias can be reduced by operating the probe at higher temperatures in an attempt to ensure that no water droplets are collected on probe surfaces. 


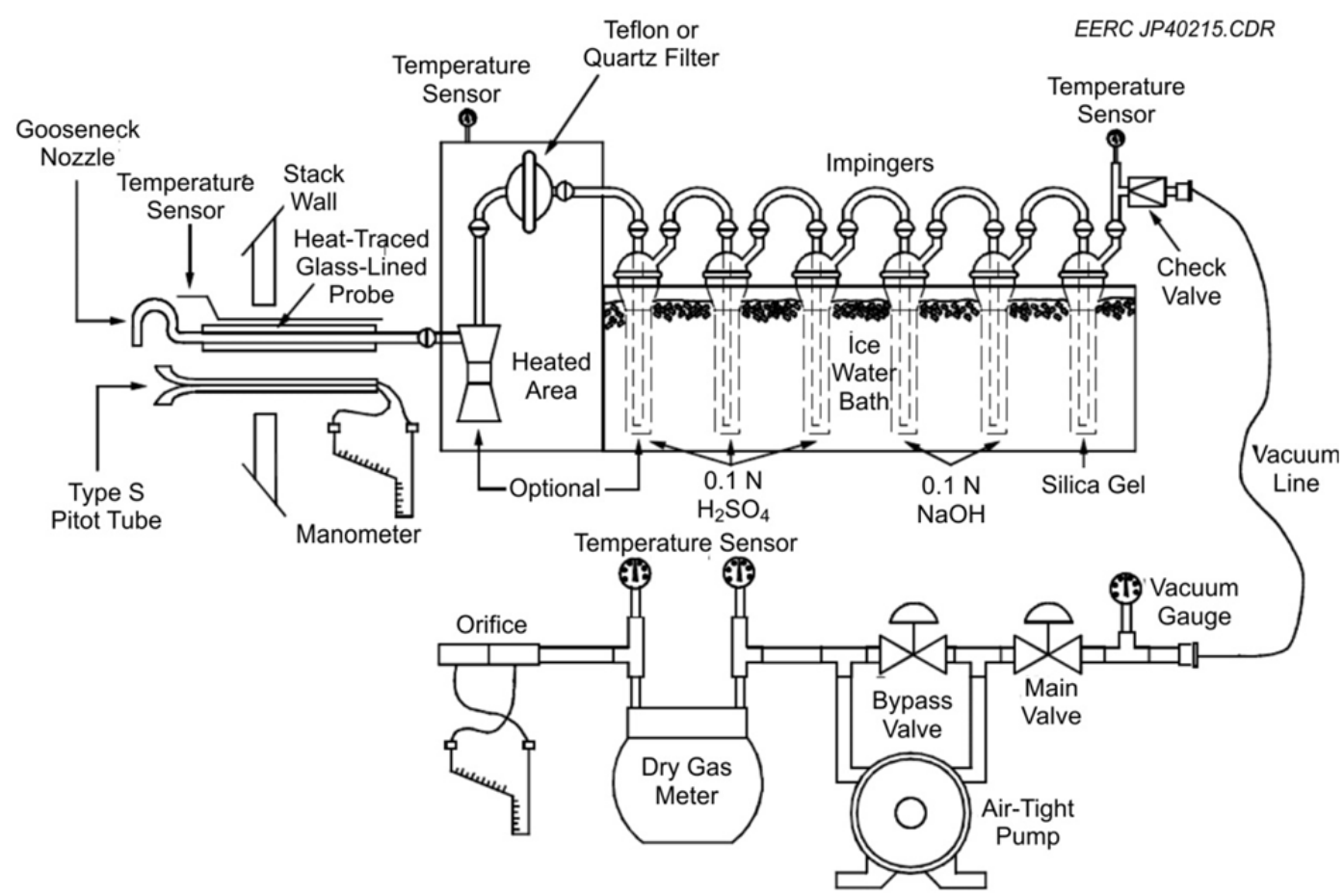

Figure 1. Schematic of the EPA M26A sampling train.

However, there is still likely to be some associated error or bias. The issue of low bias can be especially problematic if the samples are taken after a wet scrubber and at high moisture levels, because of the potential for scavenging of the $\mathrm{HCl}$ by the entrained water droplets. The isokinetic sampling in EPA M26A helps to alleviate this problem, but possible condensation in the probe can still result in a low bias if there are cold spots in the probe and sampling line before the impingers or if the heat input is insufficient to evaporate the water droplets before they contact the probe surfaces. Low-level halogen measurements, taken after a wet scrubber or at high moisture levels, should be assumed to be biased low, and this would also be true when using the optional cyclone at the probe inlet. Another approach to reducing the bias is to elevate the sample train temperature, but this may lead to a high bias if ammonia is present in the flue gas.

As outlined in the EPA document "Stack Sampling Methods for Halogens and Halogen Acids" (7), the low bias associated with EPA M26A was not consistent from test to test but can be roughly correlated with the moisture content of the flue gas. Tests at $4.8 \mathrm{ppm}(\mathrm{v}) \mathrm{HCl}$ indicated a low bias of 50\%. Another test indicated that spiked impinger recoveries were reasonable but that full-train spikes were low by a factor of 3 to 5 . The presence of $\mathrm{NH}_{4} \mathrm{Cl}$ was found to produce a positive bias in all cases, and any attempt to mitigate this bias aggravated the moisture bias. In flue gases containing ammonia slip, it could be assumed that the high bias for $\mathrm{HCl}$ due to $\mathrm{NH}_{4} \mathrm{Cl}$ could be as high as the ammonia slip value in the flue gas if the ammonia reacted with available $\mathrm{Cl}^{-}$ions. If ammonia emissions are over $10 \mathrm{ppm}(\mathrm{v})$, the potential high bias for $\mathrm{HCl}$ using EPA M26A could be several times the MATS limit for existing plants and could be as high as $10 \mathrm{ppm}(\mathrm{v})$. This 10-ppm(v) bias would make it impossible to demonstrate emission compliance for utilities. 


\section{Mercury and Nonmercury Metal HAPs (EPA M29)}

The reference method for mercury and nonmercury metal HAPs is EPA M29 (8) (www.epa.gov/ttn/emc/promgate/m-29.pdf). The method was designed to measure the solid particulate and gaseous emissions of mercury and 16 other trace elements. A schematic of the EPA M29 sampling train is presented in Figure 2. As shown, the EPA M29 sampling train consists of a particulate filter and seven impingers. The filter is used to collect particulate-phase metals. Following an optional moisture knockout impinger, gaseous species are collected in two pairs of impingers connected in series containing different absorption solutions. The non-Hg gaseous metals, along with oxidized vapor-phase $\mathrm{Hg}$, are captured in the first pair of impingers containing aqueous solutions of $5 \%$ nitric acid $\left(\mathrm{HNO}_{3}\right)$ and $10 \%$ hydrogen peroxide $\left(\mathrm{H}_{2} \mathrm{O}_{2}\right)$, while the elemental $\mathrm{Hg}$ is captured in a second pair of impingers containing aqueous solutions of $4 \%$ potassium permanganate $\left(\mathrm{KMnO}_{4}\right)$ and $10 \%$ sulfuric acid $\left(\mathrm{H}_{2} \mathrm{SO}_{4}\right)$. An empty impinger is located between the two sets of impingers to reduce the potential for blowback of $\mathrm{KMnO}_{4}$ into the second $\mathrm{HNO}_{3} / \mathrm{H}_{2} \mathrm{O}_{2}$ impinger during leak checks. The last impinger in the sampling train contains silica gel to prevent contamination and entrap moisture that may otherwise travel downstream and damage the dry-gas meter and pump. Stack testers may omit the permanganate impingers and measure mercury separately with a sorbent trap method such as EPA M30B.

The published detection limits for EPA M29 for a sample volume of $1.25 \mathrm{~m}^{3}$ are shown in Table 7 (9). These values were calculated from instrument detection limits for primarily graphite furnace atomic absorption spectroscopy (GFAAS), with the exception of $\mathrm{Ni}$ which was determined from the detection limit of inductively coupled plasma-atomic emission spectroscopy (ICP-AES) and $\mathrm{Hg}$ via cold-vapor atomic absorption spectroscopy (CVAAS). Also in Table 7, the detection limits using inductively coupled plasma-mass spectroscopy (ICP-MS) are presented (sample volume of $1.0 \mathrm{~m}^{3}$ ). As can be seen, much lower concentrations can be

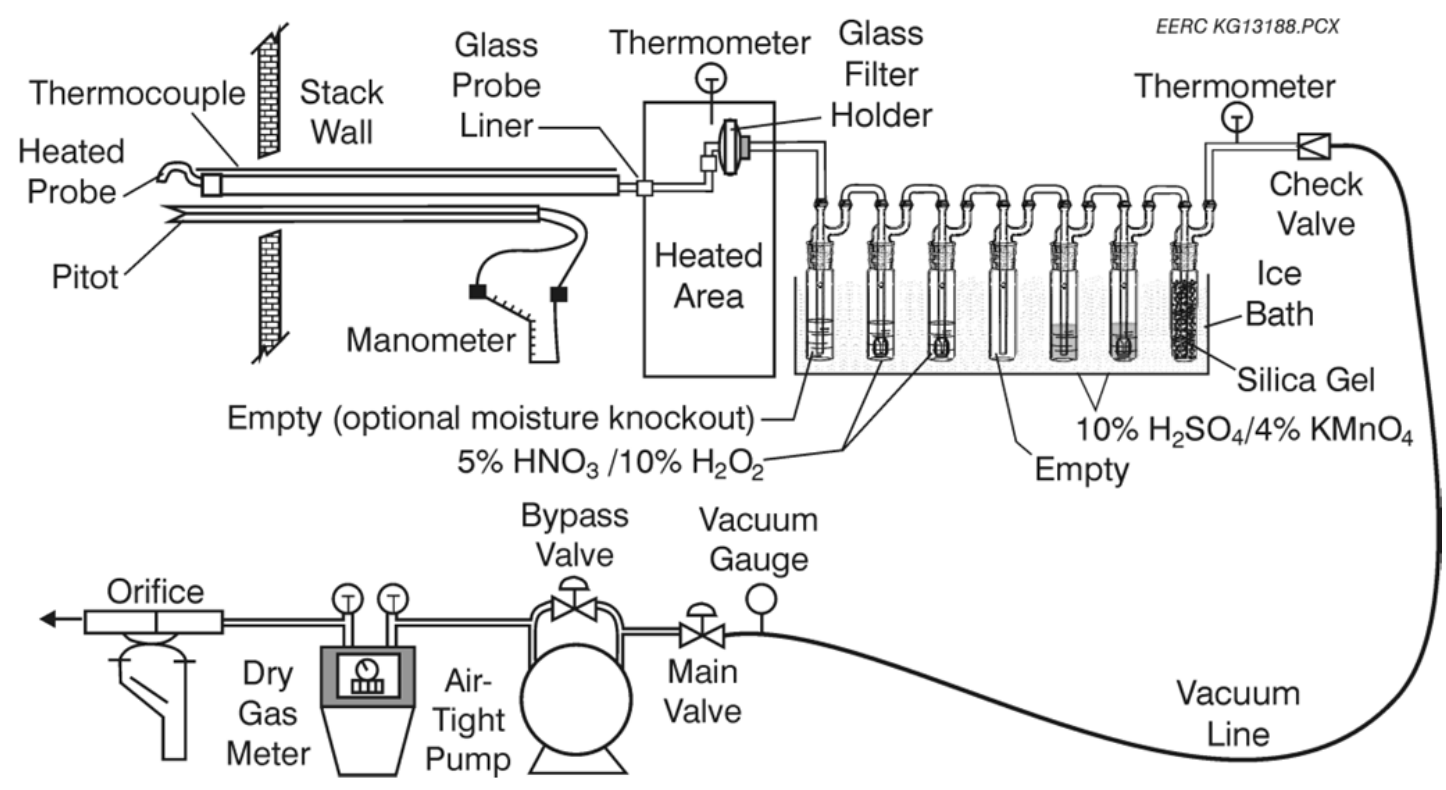

Figure 2. Schematic of the EPA M29 sampling train. 


\begin{tabular}{lcc}
\hline & $\begin{array}{c}\text { Published EPA M29 Detection Limits } \\
\text { with GFAAS, } \mu \mathrm{g} / \mathrm{dNm}^{3}\end{array}$ & $\begin{array}{c}\text { EPA M29 Detection Limits with } \\
\text { ICP-MS, } \mu \mathrm{g} / \mathrm{dNm}^{3}\end{array}$ \\
\hline Antimony & 1.1 & 0.1 \\
Arsenic & 0.4 & 0.5 \\
Beryllium & 0.08 & 0.1 \\
Cadmium & 0.03 & 0.1 \\
Chromium & 0.3 & 0.1 \\
Cobalt & 0.3 & 0.5 \\
Lead & 0.3 & 0.1 \\
Manganese & 0.3 & 0.1 \\
Mercury* & 0.56 & 0.01 \\
Nickel & 5.4 & 0.2 \\
Selenium & 0.8 & 1 \\
\hline
\end{tabular}

* Analyzed using CVAA.

obtained using ICP-MS. However, to measure these values, blank levels must be kept very low and the impingers contaminant-free. With very careful sampling and analysis, these detection limits can be obtained, but practical detection limits are often $50 \%$ to $100 \%$ higher because of the potential impacts of field testing. Detection limits can be improved by increasing the sampling time; however, other flue gas constituents may consume the impinger chemicals, causing the values to be biased low. It should be noted that the detection limits for mercury have improved by a factor of 10 as a result of improvement in analysis technology since EPA M29 was published in 2000.

Concerns with using EPA M26/26A and M29 to meet the MATS requirements include the following:

1. Both methods are difficult to use, require highly trained personnel, and involve substantial preparation.

2. Both methods require the use of toxic chemicals, creating issues for worker safety, shipping, and disposal.

3. A very high level of $\mathrm{QC}$ is required, not only for the sample analysis, but also for the sampling activities.

4. The detection limits for EPA M29 may not be adequate, in some cases, to measure accurately at the existing unit limits established under MATS. Several of the new unit limits (e.g., As, $\mathrm{Be}, \mathrm{Co}$, and $\mathrm{Cd}$ for coal and new continental liquid oil units) are well below the capabilities of EPA M29 $(10,11)$. At these low levels, field blanks become an issue. 
5. Inclusion of mercury in a M29 test creates a risk of contaminating the sample with manganese, because of the additional permanganate impinger that must be added to the sampling train.

\section{ME-ST Sorbent Trap Sampling Methods}

The EERC has developed two novel sorbent trap-based methods that can be used to sample for trace elements and/or halogens (with a focus on $\mathrm{HCl}$ ). Although the proprietary sorbent trap materials differ, the sampling procedures and equipment used to capture $\mathrm{HCl}$ and trace metals are very similar. The sample traps are illustratively shown in Figure 3 and pictorially in Figure 4.

Both the ME-ST-M and ME-ST-H methods draw an isokinetic flue gas sample through a series of plugs and trap materials, as shown in Figure 3 (It should be noted that ME-ST-H method can also be used for nonisokinetic sampling). The metals and/or halogens are targeted for capture in the first plug-and-trap section. The second trap serves as a quality check to make sure that none of the metals and/or halogens $(\mathrm{HCl})$ break through the first trap. The sampling procedures are similar to those used in EPA M30B "Determination of Total Vapor Phase Mercury Emissions from Coal-Fired Combustion Sources Using Carbon Sorbent Traps" (www.epa.gov/ttn/emc/promgate/Meth30B.pdf).

\section{ME-ST-H Method for Halogens}

The ME-ST-H method was designed for isokinetic sampling, which is required for flue gas with high relative moisture content (EPA M26A), but it also can be used for nonisokinetic sampling in dry flue gas environments (EPA M26). Approximately $250 \mathrm{~L}$ of flue gas is drawn through a series of glass plugs and beds of proprietary sorbent material (shown in

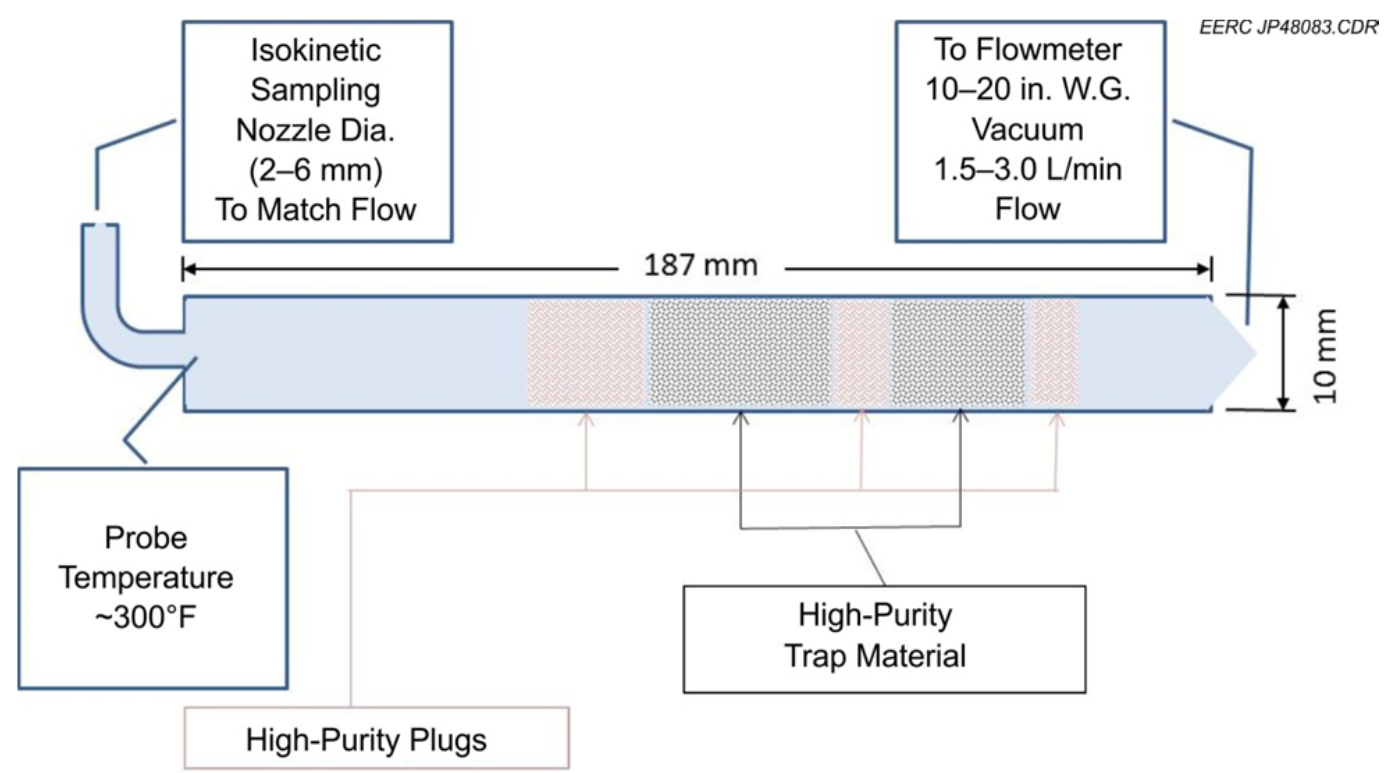

Figure 3. Conceptual view of the ME-ST method. 


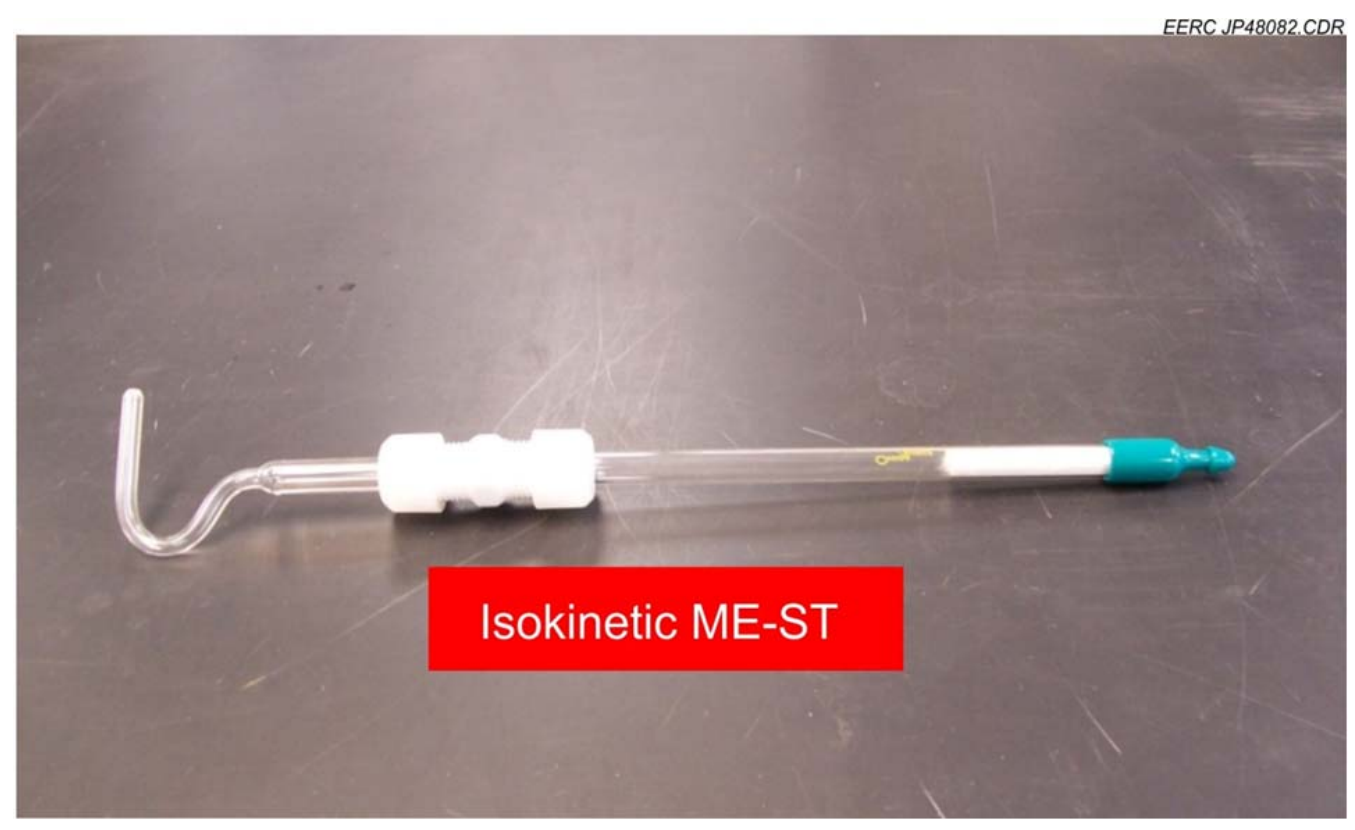

Figure 4. Example photo of the ME-ST method.

Figure 3). Similar to the filter of EPA Method 26/26A, the glass wool plug is intended to capture particulate matter that may enter the trap. The glass wool plug is also analyzed for $\mathrm{HCl}$. The trap material is formulated to capture halogen compounds, in particular $\mathrm{HCl}$. To ensure that condensation does not form, the ME-ST-H trap is maintained at the sampling flue gas temperature, or $300^{\circ} \mathrm{F}$, whichever is higher.

\section{ME-ST-M Method for Trace Metals}

Similar to the ME-ST-H method, the ME-ST-M method draws an isokinetic flue gas sample of approximately $250 \mathrm{~L}$ through a series of quartz plugs and beds of proprietary sorbent. However, the trap material that is used is formulated to target capture of the trace elements regulated by MATS. To ensure that condensation does not form, the ME-ST-M trap is maintained at the sampling flue gas temperature, or $300^{\circ} \mathrm{F}$, whichever is higher.

One of the primary concerns and challenges of this method was to obtain low enough blank values for the sorbent and plug materials. Because the amount of each trace element captured during sampling is very small, the blank values need to be as close to zero as possible. As shown in Figures 5 and 6, there was a distinct improvement in the blank values after modifications were made to the sorbent material and plugs. The initial materials used for trap sections contained trace amounts of some of the target metals. Replacement of the sorbent and plug components decreased the blank values for all of the target trace metals. The error bars in these figures indicate the relative standard deviation (RSD). Where an error bar is not shown, this indicates all values were below detection limits (i.e., Se in Figure 5). However, for four of the metals $(\mathrm{Cr}, \mathrm{Pb}, \mathrm{Mn}$, and $\mathrm{Ni}$ ), it has been significantly harder to reduce background and/or contamination levels to below MATS requirements. As a result, these metals continue to present an ongoing challenge, for both ME-ST-M and M29. 


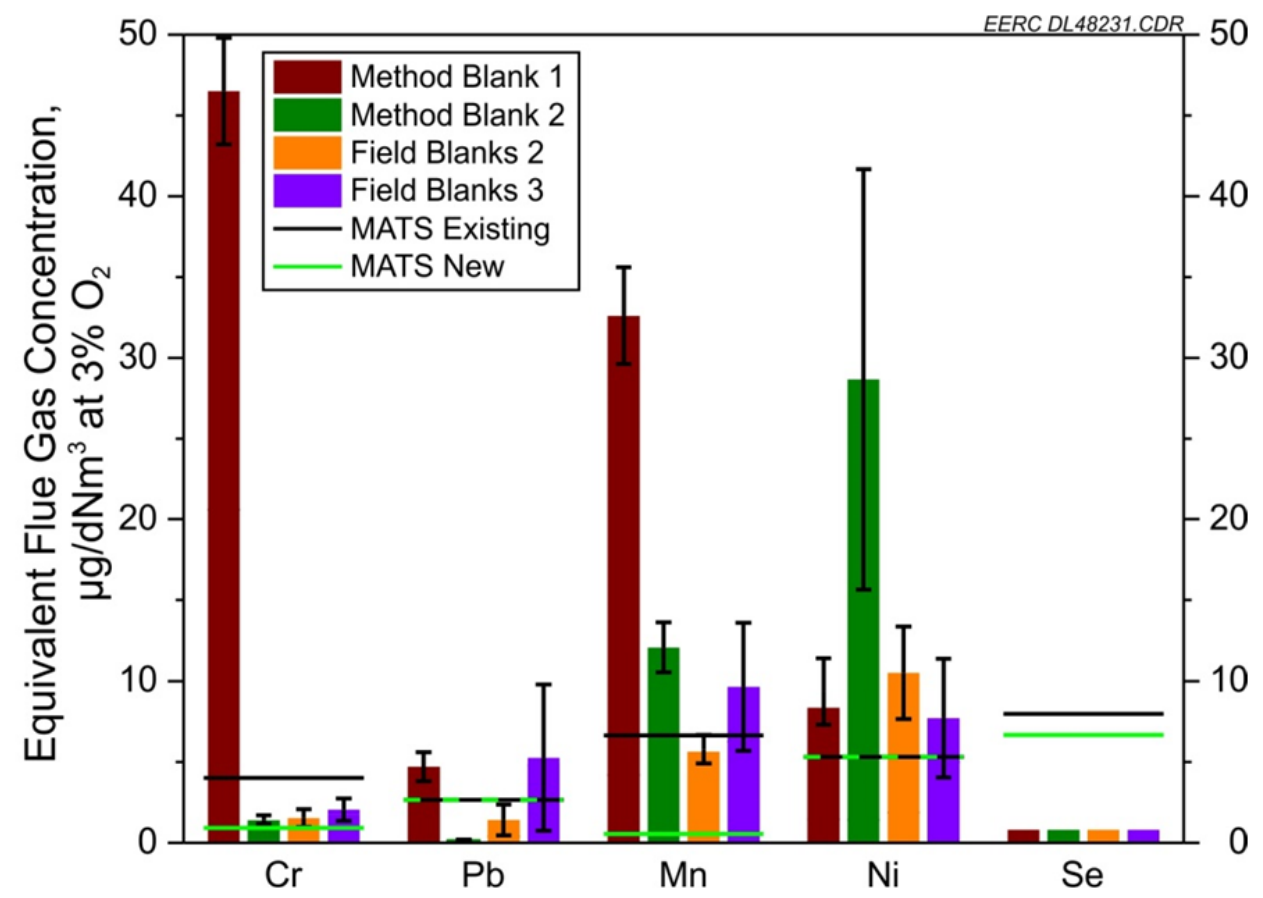

Figure 5. Improvement in background concentrations of $\mathrm{Cr}, \mathrm{Pb}, \mathrm{Mn}, \mathrm{Ni}$, and $\mathrm{Se}$.

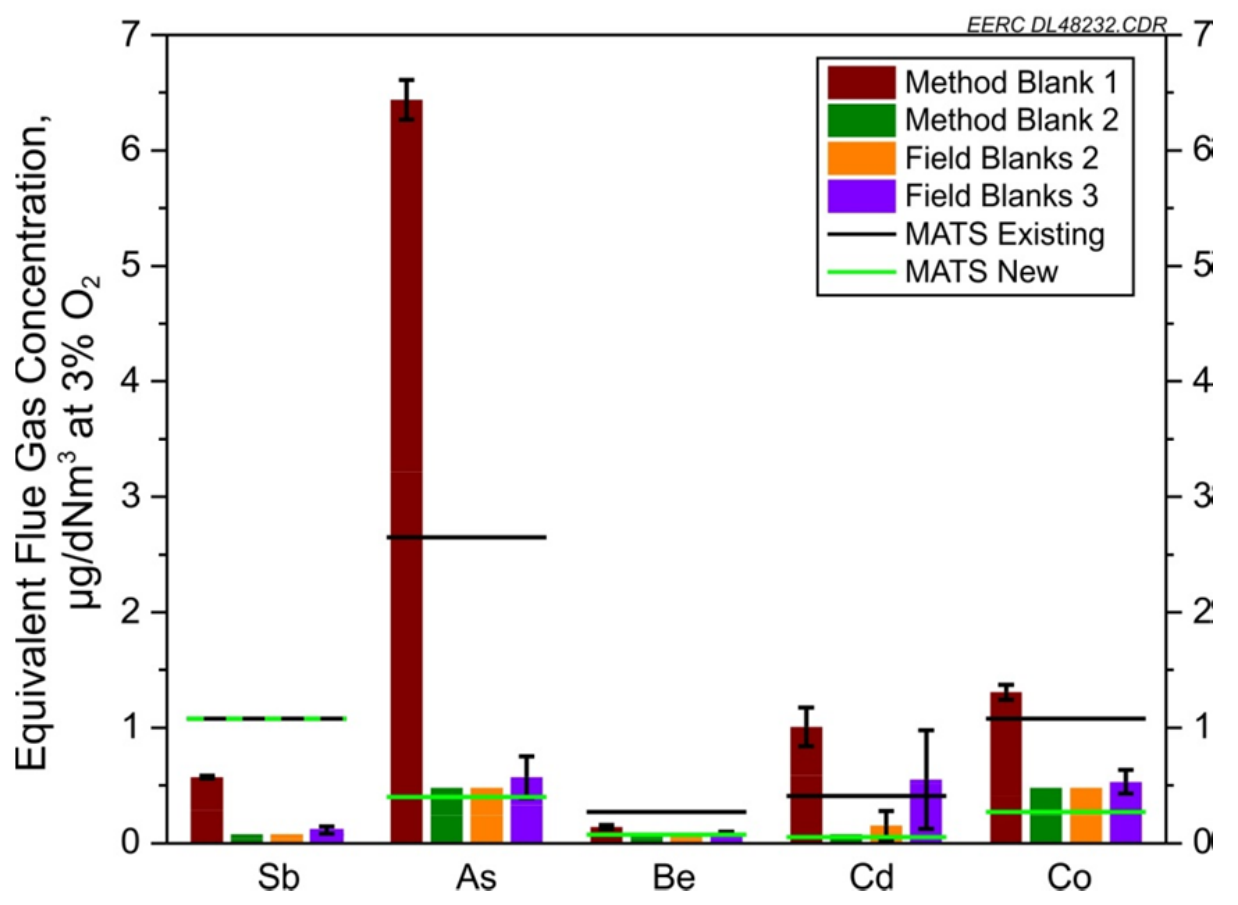

Figure 6. Improvement in background concentrations of $\mathrm{Sb}, \mathrm{As}, \mathrm{Be}, \mathrm{Cd}$, and $\mathrm{Co}$. 


\section{Halogen Analysis}

Analysis of samples by EPA M26A is typically done using ion chromatography (IC). IC is the preferred analysis method because of its ability to analyze for all of the halogens and its suitability for automated systems, which greatly increases sample throughput. The IC instrument/laboratory detection limit of $0.1 \mathrm{mg} / \mathrm{L}$ for halogens is significantly lower than required for the MATS emission limits. This shows that the analytical instrumentation is capable of providing adequate detection levels to measure $\mathrm{HCl}$ at the levels required by MATS.

Analysis of the samples from the ME-ST-H method is completed using IC. In this project, the analysis was conducted at an off-site laboratory; however, this method is amenable to on-site analysis, with appropriate measures to maintain a clean environment. Prior to analysis, the halogens collected by the glass plugs and sorbent material are simply dissolved in high-purity, deionized water to ensure all halogens from ME-ST-H sampling are in solution. A calibration curve and baseline are established for the IC, the sample is injected into the IC, and the peak for each halide ion of interest is determined. The concentration in the injected sample is then calculated based on the calibration curve. The stack emission is calculated from the liquid concentration, dilution factor (if any), stack gas volume sampled, temperature, and gas composition.

The stack emission detection limit for the ME-ST-H method is estimated to be $0.01 \mathrm{ppm}(\mathrm{v})$ on a dry basis, based on the volume of flue gas sampled for this project $(250 \mathrm{~L})$. This detection limit was determined based on matrix-matched standards. Comparing this detection limit with the MATS limits in Table 5, the analytical instrumentation appears to be capable of providing adequate sensitivity to detect $\mathrm{HCl}$ well below the MATS limits for both existing and new/reconstructed coal-fired units. However, a limit of quantitation (LOQ) has not yet been determined for the ME-ST-H method. Typically, the LOQ is at least 2.5 times higher than the detection limit, and for a method to be sufficiently accurate for compliance testing, the regulatory limit needs to be higher than the LOQ (9).

\section{Metals Analysis}

The following ASTM International (ASTM) and EPA methods were employed for the preparation and analysis of the different samples: EPA SW846 3052 (Microwave Assisted Acid Digestion of Siliceous and Organically Based Matrices), SW-846 6020A (ICP-MS), and ASTM Method D6357 (Standard Test Methods for Determination of Trace Elements in Coal, Coke, and Combustion Residues from Coal Utilization Processes by ICP-AES, ICP-MS, and GFAAS). Samples from both EPA M29 and the ME-ST-M method are analyzed with ICP-MS for the nonmercury metals. $\mathrm{Hg}$ analysis is done separately with CVAAS. ICP-MS is the preferred analytical method because of its ability to analyze for all of the metals with the lowest detection limits. CVAAS is the preferred method for $\mathrm{Hg}$ analysis because of its selectivity, resulting from the removal of interferents during the cold-vapor generation process as well as the sensitivity of atomic absorption for Hg. The detection limits of ICP-MS for metals are shown in Table 7 along with the detection limit for $\mathrm{Hg}$ via CVAAS. The EERC CVAAS instrument/laboratory detection limit of $0.01 \mu \mathrm{g} / \mathrm{L}$ for $\mathrm{Hg}$ is significantly lower than required for the MATS emission limits for existing coal-fired units. This shows that the analytical instrumentation is capable of providing adequate detection levels to measure $\mathrm{Hg}$ at the levels required by MATS. 
Although the detection limits for the ICP-MS method are such that it appears it can be used to meet the required MATS emission limits for individual trace metals for existing units, the emission limits for several of the metals are at or near the detection limit for ICP-MS. As a result, the precision of the analysis is not very good, as method precision always becomes much worse as the detection limit is approached. Specifically, there are four metals (As, Be, Cd, and Co) for which the MATS limit for existing coal-fired units is at the detection limit for ICP-MS, as shown in Table 7. For a new or reconstructed unit, it becomes more problematic. Hg was not included in this background study, as the instrumental detection limit is a factor of 1000 less than that required for the MATS limit, and previous work has reduced background levels to near zero (4).

The estimated MDLs shown in Table 8 do not take into account sampling variability or background blanks, which can be significant at these levels for several of the metals. In addition, a LOQ has not yet been determined for the ME-ST-M method; for a method to be sufficiently accurate for compliance testing, the regulatory limit needs to be higher than the LOQ.

Table 8. Estimated Detection Limits of EPA M29 and the ME-ST-M Method

\begin{tabular}{|c|c|c|c|}
\hline Element & $\begin{array}{l}\text { ICP-MS Detection } \\
\text { Limit, } \mu \mathrm{g} / \mathrm{L} \\
\end{array}$ & $\begin{array}{c}\text { heoretical EPA M2 } \\
\text { Detection Limit, }^{\text {a }} \\
\mu \mathrm{g} / \mathrm{dNm}^{3}\end{array}$ & $\begin{array}{c}\text { Theoretical ME-ST-M } \\
\text { Detection Limit, }{ }^{\mathrm{b}} \mu \mathrm{g} / \mathrm{dNm}^{3}\end{array}$ \\
\hline Antimony & 0.1 & 0.1 & 0.05 \\
\hline Arsenic & 0.5 & 0.5 & 0.3 \\
\hline Beryllium & 0.1 & 0.1 & 0.05 \\
\hline Cadmium & 0.1 & 0.1 & 0.05 \\
\hline Chromium & 0.1 & 0.1 & 0.05 \\
\hline Cobalt & 0.5 & 0.5 & 0.3 \\
\hline Lead & 0.1 & 0.1 & 0.05 \\
\hline Manganese & 0.1 & 0.1 & 0.05 \\
\hline Mercury $^{c}$ & 0.01 & 0.01 & 0.005 \\
\hline Nickel & 0.2 & 0.2 & 0.1 \\
\hline Selenium & 1 & 1 & 0.5 \\
\hline
\end{tabular}

${ }^{\mathrm{a}}$ Based on recovery and dilution volumes, with a sample volume of $1 \mathrm{dNm}^{3}$.

${ }^{\mathrm{b}}$ Based on recovery and dilution volumes, with a sample volume of $0.25 \mathrm{dNm}^{3}$.

${ }^{\mathrm{c}}$ CVAAS.

\section{Experimental Approach}

The ME-ST methods were evaluated at three power plants burning lignite coal. A sitespecific test plan (SSTP) was developed for each site detailing the sampling plan and schedule. (12-14). In general, sampling activities were performed over the course of 1 week at each site, as shown in Table 9. ME-ST-H, ME-ST-M, EPA M29, and EPA M26A sampling was conducted at the stack of each site as shown in Figure 7. 
Table 9. Typical Test Schedule

\begin{tabular}{lc}
\hline Day & Description \\
\hline Sunday & Travel to site and begin setup \\
Monday & Conduct safety orientation and setup, begin sampling \\
Tuesday & Sampling Day 1 \\
Wednesday & Sampling Day 2 \\
Thursday & Sampling Day 3 \\
Friday/Saturday & Tear down and travel back to the EERC \\
\hline
\end{tabular}

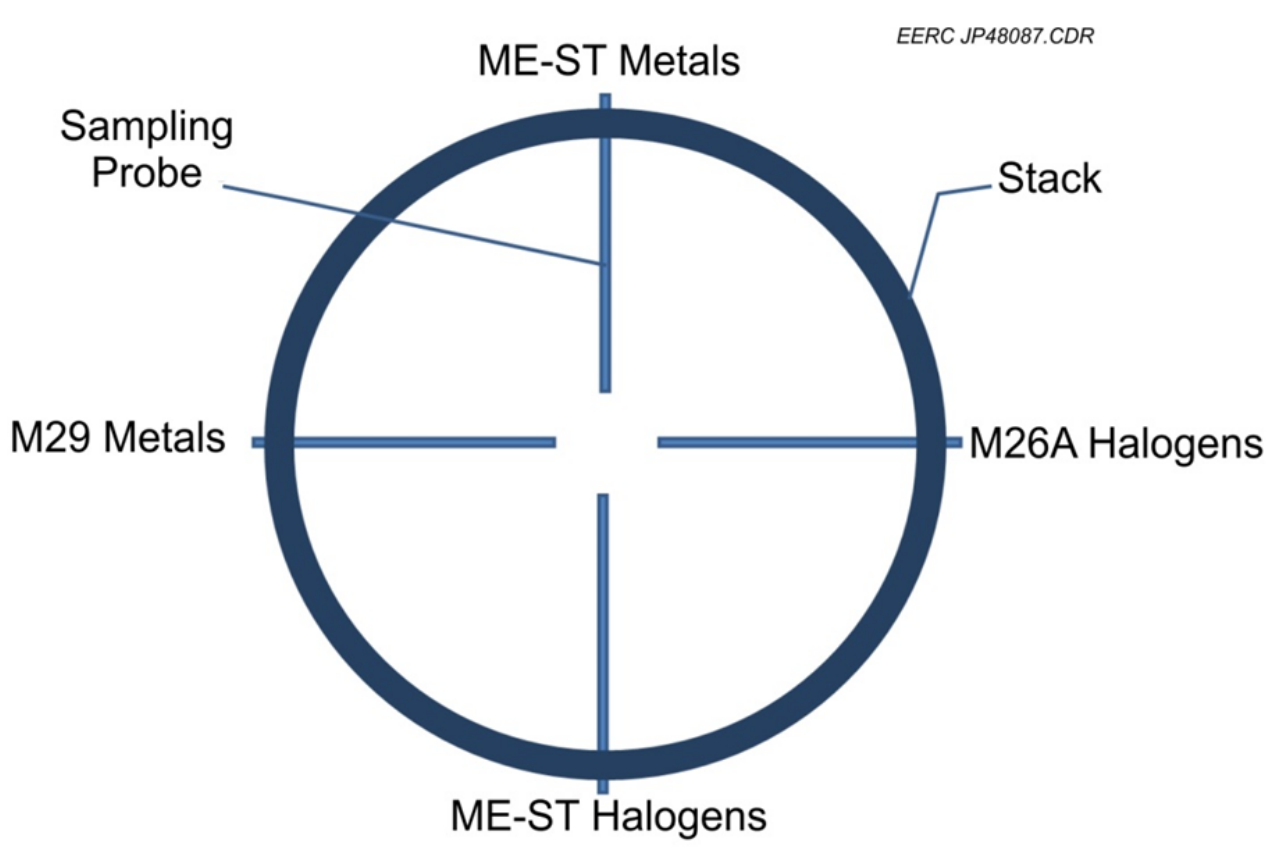

Figure 7. Stack sampling.

Trace element stack emission data for the 11 HAP metals ( $\mathrm{Sb}, \mathrm{As}, \mathrm{Be}, \mathrm{Cd}, \mathrm{Cr}, \mathrm{Co}, \mathrm{Pb}, \mathrm{Mn}$, $\mathrm{Hg}, \mathrm{Ni}$, and $\mathrm{Se}$ ) were collected at each host site using both EPA M29 and the ME-ST-M method. Analysis of the same elements was performed on coal samples collected daily during the sampling period. The EPA M29 and ME-ST-M samples were sampled for the same duration. The probe depth was similar for each test method to ensure that the two methods were sampling similar and representative flue gas. Nine (or more) EPA M29 and nine dual ME-ST-M samples (18 total) were collected over a 3-4-day period. At the same stack-sampling area, and in a manner similar to the EPA M29 and ME-ST-M sampling, EPA M26A and an additional set of dual ME-ST-H samples were used to collect data for halogen emissions. While the ME-ST-H method may accurately measure $\mathrm{F}, \mathrm{Cl}$, and $\mathrm{Br}$, only $\mathrm{Cl}$ (a measure of $\mathrm{HCl}$ ) was of primary interest. Trace element and halogen sampling was conducted at the same time, as illustrated in Figure 7. 
Table 10 displays the daily summary for the data that were collected at each host site. Three sets of each data set were collected during each of the test days. In addition to the stack trace metal and halogen emission data, coal samples were taken twice a day (morning and evening), with a composite analyzed for the 11 HAP metals and halogens.

The EPA M29 and EPA M26A samples were recovered according to each of the methods on-site utilizing a laboratory trailer. Once the test team returned to the EERC, the EPA M29, EPA M26A, ME-ST-H, and ME-ST-M samples were submitted to the EERC's Analytical Research Laboratory (ARL) for preparation and analysis. In the ARL, the ME-ST-M samples were recovered and, along with the EPA M29 filter samples, prepared for ICP-MS analysis by microwave digestion. ME-ST-H samples were recovered and prepared for IC analysis along with EPA M26A samples.

Table 10. Daily Test Matrix and Associated Sampling

\begin{tabular}{|c|c|c|c|c|c|}
\hline Sample Type & $\begin{array}{c}\text { Sample } \\
\text { Duration, hr }\end{array}$ & $\begin{array}{l}\text { Sampling } \\
\text { Location }\end{array}$ & Unit Operation & $\begin{array}{c}\text { Coal } \\
\text { Sampling }\end{array}$ & Gas Analyzer \\
\hline \multicolumn{6}{|l|}{ Day 1} \\
\hline M29-1, ME-ST-M1 & 2 & \multirow[t]{2}{*}{ Stack } & \multirow[t]{2}{*}{ Full load } & \multirow[t]{2}{*}{ Twice daily } & \multirow{6}{*}{$\begin{array}{l}\text { During each } \\
\text { sample period } \\
\text { During each } \\
\text { sample period } \\
\text { During each } \\
\text { sample period }\end{array}$} \\
\hline M26A-1, ME-ST-H1 & 2 & & & & \\
\hline M29-2, ME-ST-M2 & 2 & Stack & Full load & Twice daily & \\
\hline M26A-2, ME-ST-H2 & 2 & \multirow{3}{*}{ Stack } & \multirow{3}{*}{ Full load } & \multirow{3}{*}{ Twice daily } & \\
\hline M29-3, ME-ST-M3 & 2 & & & & \\
\hline M26A-3, ME-ST-H3 & 2 & & & & \\
\hline \multicolumn{6}{|l|}{ Day 2} \\
\hline M29-4, ME-ST-M4 & 2 & \multirow[t]{2}{*}{ Stack } & \multirow[t]{2}{*}{ Full load } & \multirow[t]{2}{*}{ Twice daily } & \multirow{6}{*}{$\begin{array}{l}\text { During each } \\
\text { sample period } \\
\text { During each } \\
\text { sample period } \\
\text { During each } \\
\text { sample period }\end{array}$} \\
\hline M26A-4, ME-ST-H4 & 2 & & & & \\
\hline M29-5, ME-ST-M5 & 2 & Stack & Full load & Twice daily & \\
\hline M26A-5, ME-ST-H5 & 2 & \multirow{3}{*}{ Stack } & \multirow{3}{*}{ Full load } & \multirow{3}{*}{ Twice daily } & \\
\hline M29-6, ME-ST-M6 & 2 & & & & \\
\hline M26A-6, ME-ST-H6 & 2 & & & & \\
\hline \multicolumn{6}{|l|}{ Day 3} \\
\hline M29-7, ME-ST-M7 & 2 & \multirow[t]{2}{*}{ Stack } & \multirow[t]{2}{*}{ Full load } & \multirow[t]{2}{*}{ Twice daily } & \multirow{6}{*}{$\begin{array}{l}\text { During each } \\
\text { sample period } \\
\text { During each } \\
\text { sample period } \\
\text { During each } \\
\text { sample period }\end{array}$} \\
\hline M26A-7, ME-ST-H7 & 2 & & & & \\
\hline M29-8, ME-ST-M8 & 2 & Stack & Full load & Twice daily & \\
\hline M26A-8, ME-ST-H8 & 2 & & & & \\
\hline M29-9, ME-ST-M9 & 2 & Stack & Full load & Twice daily & \\
\hline M26A-9, ME-ST-H9 & 2 & & & & \\
\hline
\end{tabular}

\section{DESCRIPTION OF POWER PLANTS AND COAL ANALYSIS}

Three coal-fired power plant stacks were sampled for this project. An illustration showing the configurations and sampling location is provided for each plant (Figures 8 through 10). All three plants burned North Dakota lignite. The coal analysis for each site is provided in Table 11. The complete coal analysis for each plant is provided in Appendix A. 
Table 11. Coal Analysis for Each Plant

\begin{tabular}{|c|c|c|c|c|c|c|}
\hline \multirow{3}{*}{$\begin{array}{l}\text { Sample: } \\
\text { Number of Samples: } \\
\text { Analysis }\end{array}$} & \multirow{2}{*}{\multicolumn{2}{|c|}{$\begin{array}{c}\text { Plant } 1 \\
6\end{array}$}} & \multicolumn{2}{|c|}{ Plant 2} & \multicolumn{2}{|c|}{ Plant 3} \\
\hline & & & \multicolumn{2}{|c|}{6} & \multicolumn{2}{|r|}{6} \\
\hline & Avg. & Std. Dev. & Avg. & Std. Dev. & Avg. & Std. Dev. \\
\hline Heating Value, Btu/lb (as received) & 6288 & 206 & 6771 & 107 & 6282 & 172 \\
\hline \multicolumn{7}{|l|}{ Proximate Analysis, \% } \\
\hline Moisture & 32.51 & 0.54 & 35.15 & 0.35 & 37.25 & 0.45 \\
\hline Volatile Matter & 22.96 & 0.57 & 23.80 & 0.58 & 24.11 & 0.46 \\
\hline Fixed Carbon & 34.19 & 1.19 & 34.52 & 0.48 & 30.30 & 1.52 \\
\hline Ash & 10.34 & 1.98 & 6.54 & 0.56 & 8.35 & 2.03 \\
\hline \multicolumn{7}{|l|}{ Ultimate Analysis, \% } \\
\hline Hydrogen* & 2.89 & 0.12 & 3.05 & 0.02 & 2.44 & 0.09 \\
\hline Carbon & 38.25 & 1.36 & 41.01 & 0.47 & 38.18 & 0.84 \\
\hline Nitrogen & 0.56 & 0.02 & 0.52 & 0.01 & 0.59 & 0.03 \\
\hline Sulfur & 0.79 & 0.11 & 1.00 & 0.09 & 0.87 & 0.67 \\
\hline Oxygen* & 14.67 & 0.62 & 12.73 & 0.30 & 12.33 & 1.38 \\
\hline \multicolumn{7}{|l|}{ Halogens, $\mu \mathrm{g} / \mathrm{g}$ dry } \\
\hline Chlorine & 19.3 & 3.7 & 12.9 & 2.2 & 15.0 & 1.7 \\
\hline Fluorine & 129 & 13 & $<60$ & - & $<60$ & - \\
\hline Bromine & 9.2 & 4.1 & $<6$ & - & $<6$ & - \\
\hline \multicolumn{7}{|l|}{ Trace Elements, $\mu \mathrm{g} / \mathrm{g}$ dry } \\
\hline Antimony & 0.82 & 0.15 & 0.27 & 0.04 & 0.36 & 0.04 \\
\hline Arsenic & 12 & 2 & 3.20 & 0.66 & 4.88 & 1.20 \\
\hline Beryllium & 0.674 & 0.094 & 0.138 & 0.041 & 0.395 & 0.075 \\
\hline Cadmium & 0.15 & 0.02 & 0.050 & 0.003 & 0.063 & 0.008 \\
\hline Chromium & 16.3 & 3.5 & 8.96 & 1.91 & 5.33 & 2.48 \\
\hline Cobalt & 2.37 & 0.35 & 0.960 & 0.061 & 1.74 & 0.09 \\
\hline Lead & 4.82 & 0.62 & 1.55 & 0.19 & 3.38 & 0.51 \\
\hline Manganese & 73.1 & 8.2 & 38.2 & 9.3 & 84.4 & 4.6 \\
\hline Mercury & 0.102 & 0.016 & 0.0770 & 0.0104 & 0.145 & 0.074 \\
\hline Nickel & 13.6 & 11.6 & 5.74 & 1.62 & 2.26 & 0.38 \\
\hline Selenium & 0.62 & 0.07 & 0.53 & 0.08 & 0.65 & 0.09 \\
\hline
\end{tabular}

* Moisture not included for hydrogen and oxygen.

Plant 1

Plant 1 is equipped with low- $\mathrm{NO}_{\mathrm{x}}$ burners (LNBs) and overfire air (OFA). PM is controlled on each unit by electrostatic precipitators (ESPs). Sulfur emissions are controlled on each unit by a wet limestone natural oxidation scrubber, which removes approximately $90 \%$ of the $\mathrm{SO}_{2}$ from $75 \%-80 \%$ of the flue gas. The plant unit configuration is shown in Figure 8 . Currently, the station sells most of its fly ash for concrete. 


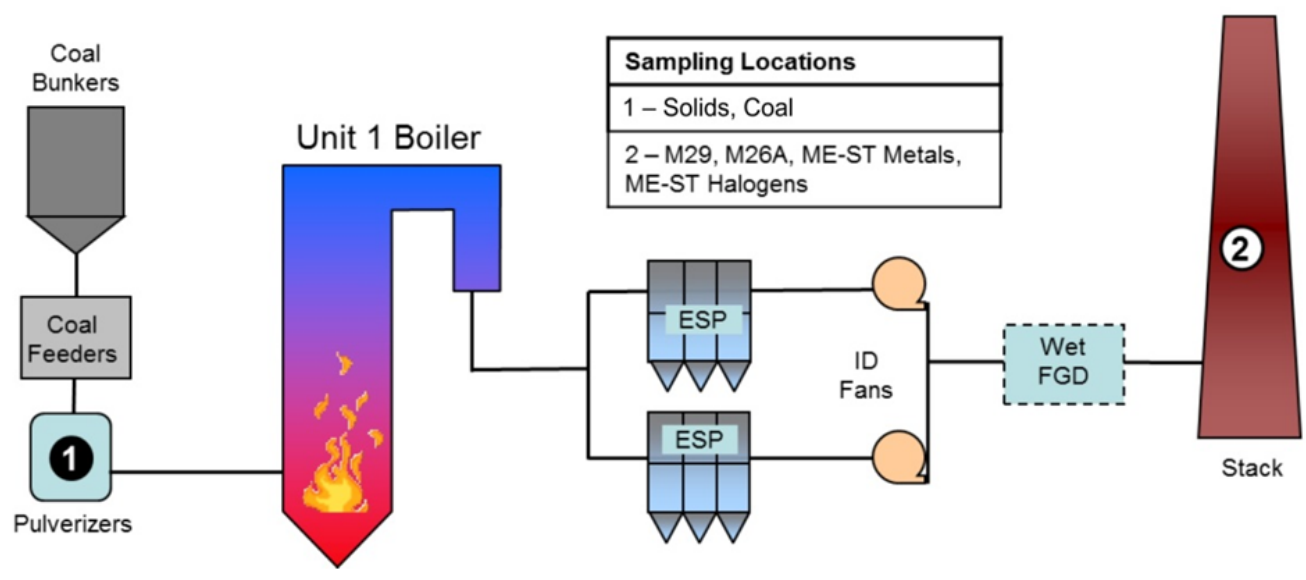

Figure 8. Configuration of Plant 1.

\section{Plant 2}

Plant 2 is equipped with OFA. PM is controlled by an ESP. A wet FGD limestone system was installed to reduce $\mathrm{SO}_{2}$ emissions. However, the FGD was not in operation during the time sampling occurred. Currently, the station sells some of its fly ash for concrete. The plant unit configuration is shown in Figure 9.

EERC JP48084.CDR

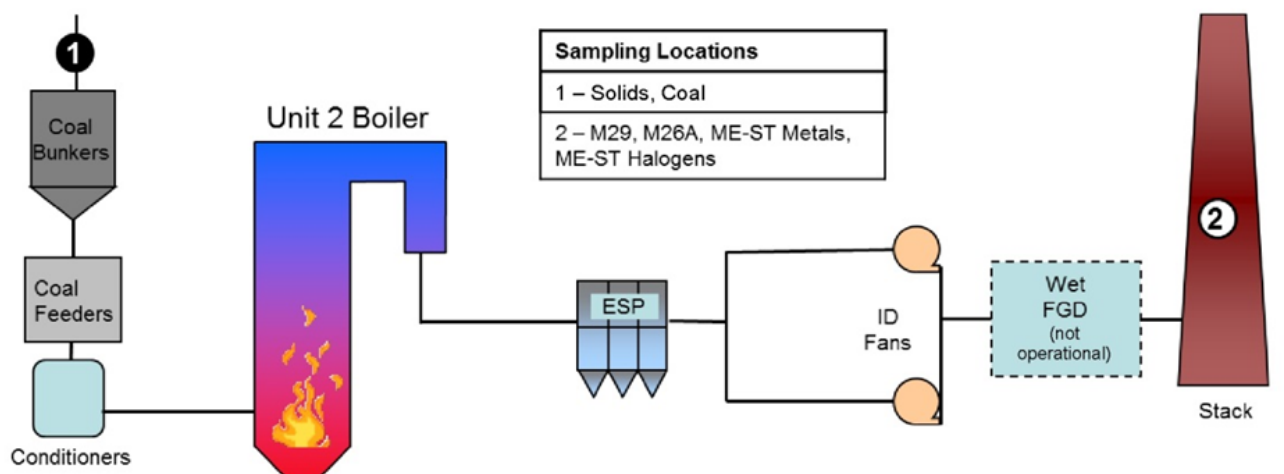

Figure 9. Configuration of Plant 2. 


\section{Plant 3}

Plant 3 is a small unit equipped with closed-coupled OFA and LNBs. PM is controlled with multicyclone mechanical dust collectors and a flooded-disc wet scrubber for particulate control. The wet scrubber is intended to be a particulate removal device that also provides $\mathrm{SO}_{2}$ removal. The unit injects activated carbon for mercury control. The plant unit configuration is shown in Figure 10.

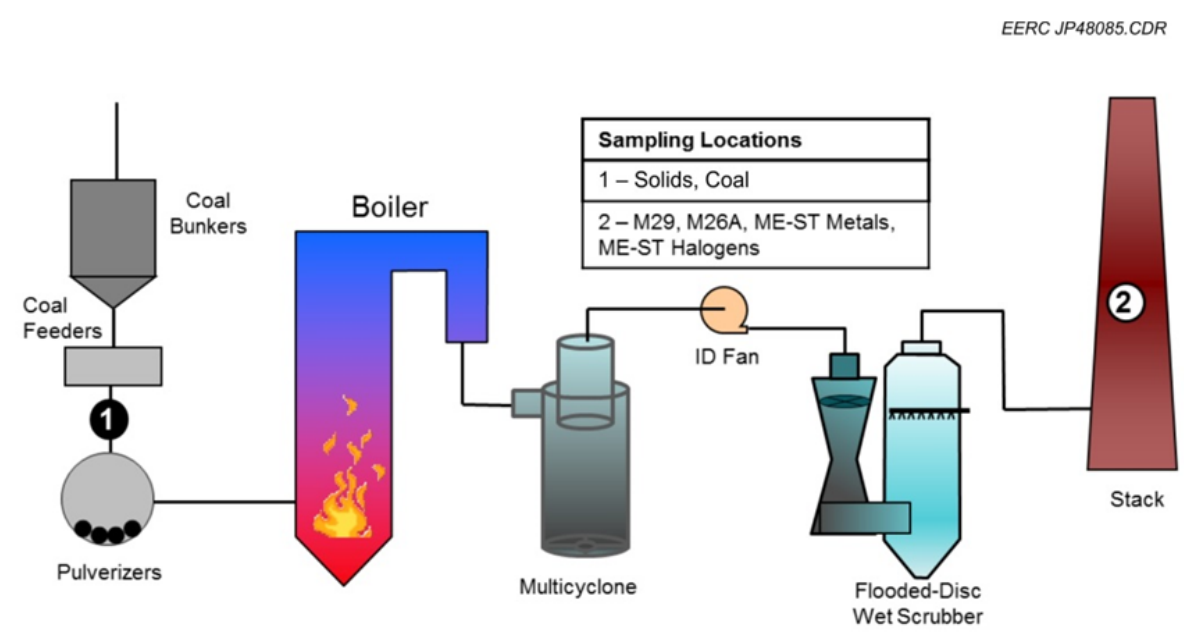

Figure 10. Configuration of Plant 3.

\section{RESULTS AND DISCUSSION}

This section presents the results of the tests conducted at the three lignite power plants, summarizes the principal findings of the study, and presents the results of a statistical analysis of a comparison between the results of the EPA standard methods and the ME-ST sorbent trap method. At least nine sets of data for each sampling method were taken. However, not all samples produced valid results. The average and standard deviation for each method were calculated only for those samples producing valid results.

\section{Halogen Results}

The coal data were used to calculate an equivalent $\mathrm{HCl}$ concentration in the flue gas for "uncontrolled" emissions. The calculation assumed all the chlorine in the fuel was converted to $\mathrm{HCl}$ in the flue gas. Because all three sites used Fort Union lignites, the coal chloride concentrations were low compared to eastern bituminous coals; all were under $20 \mathrm{ppm}(\mathrm{m})$, as shown in Table 11. EPA M26A and the ME-ST-H method were used to determine the flue gas $\mathrm{HCl}$ concentrations at each site. The results and comparison for each method at the three plants are shown in Tables 12-14 and Figures 11-13. As discussed earlier, HBr and HF results from M26A are provided in Appendix B, but they are not discussed in this report. 


\begin{tabular}{|c|c|c|}
\hline Sample & EPA M26A & ME-ST-H \\
\hline Uncontrolled Emissions $^{\mathrm{a}}$ & \multicolumn{2}{|c|}{2.00} \\
\hline 1 & 0.29 & 0.362 \\
\hline 2 & 0.30 & 0.283 \\
\hline 3 & 0.30 & 0.216 \\
\hline 4 & 0.19 & 0.165 \\
\hline 5 & 0.15 & 0.141 \\
\hline 6 & 0.20 & - \\
\hline 7 & 0.24 & 0.212 \\
\hline 8 & 0.22 & 0.202 \\
\hline 9 & 0.22 & 0.406 \\
\hline Avg. & 0.23 & 0.248 \\
\hline$\%$ Removal $^{b}$ & 88.5 & 87.6 \\
\hline$\% \mathrm{RD}^{\mathrm{c}}$ & \multicolumn{2}{|c|}{7.8} \\
\hline
\end{tabular}

${ }^{\mathrm{a}}$ Calculated from the coal chloride concentration.

${ }^{\mathrm{b}}$ Calculated from uncontrolled emissions.

${ }^{\mathrm{c}}$ Relative difference.

Table 13. Comparison of EPA M26A and the ME-ST-H Method for $\mathbf{H C l}$ at Plant 2 (all concentrations are dppmv at $3 \% \mathrm{O}_{2}$ )

\begin{tabular}{|c|c|c|}
\hline Sample & EPA M26A & ME-ST-H \\
\hline Uncontrolled Emissions $^{\mathrm{a}}$ & \multicolumn{2}{|c|}{1.43} \\
\hline 2 & 1.79 & 1.23 \\
\hline 3 & 1.38 & 1.23 \\
\hline 4 & 1.28 & - \\
\hline 5 & 1.29 & 1.17 \\
\hline 6 & 1.27 & 1.54 \\
\hline 7 & 1.30 & 1.44 \\
\hline 8 & 1.35 & 1.18 \\
\hline 9 & 1.32 & 1.13 \\
\hline 10 & 1.28 & 1.14 \\
\hline 11 & 1.32 & 1.07 \\
\hline Avg. & 1.36 & 1.24 \\
\hline$\%$ Removal $^{\mathrm{b}}$ & 4.9 & 13.3 \\
\hline$\% \mathrm{RD}$ & \multicolumn{2}{|c|}{8.8} \\
\hline
\end{tabular}

${ }^{a}$ Calculated from the coal chloride concentration.

${ }^{\mathrm{b}}$ Calculated from uncontrolled emissions. 


\begin{tabular}{|c|c|c|}
\hline Sample & EPA M26A & ME-ST-H \\
\hline Uncontrolled Emissions $^{\mathrm{a}}$ & \multicolumn{2}{|c|}{1.15} \\
\hline 1 & $<0.4$ & 0.25 \\
\hline 2 & $<0.4$ & 0.24 \\
\hline 3 & $<0.4$ & 0.23 \\
\hline 4 & $<0.4$ & 0.28 \\
\hline 5 & $<0.4$ & 0.27 \\
\hline 6 & $<0.4$ & 0.27 \\
\hline 7 & $<0.4$ & 0.24 \\
\hline 8 & $<0.4$ & 0.27 \\
\hline 11 & $<0.4$ & 0.28 \\
\hline Avg. & $<0.4$ & 0.26 \\
\hline$\%$ Removal $^{\mathrm{b}}$ & $>96$ & 77.4 \\
\hline$\% \mathrm{RD}$ & \multicolumn{2}{|c|}{$\mathrm{ND}^{\mathrm{c}}$} \\
\hline F test & \multicolumn{2}{|c|}{ - } \\
\hline
\end{tabular}

${ }^{\mathrm{a}}$ Calculated from the coal chloride concentration.

${ }^{\mathrm{b}}$ Calculated from uncontrolled emissions.

${ }^{\mathrm{c}}$ Not able to be determined.

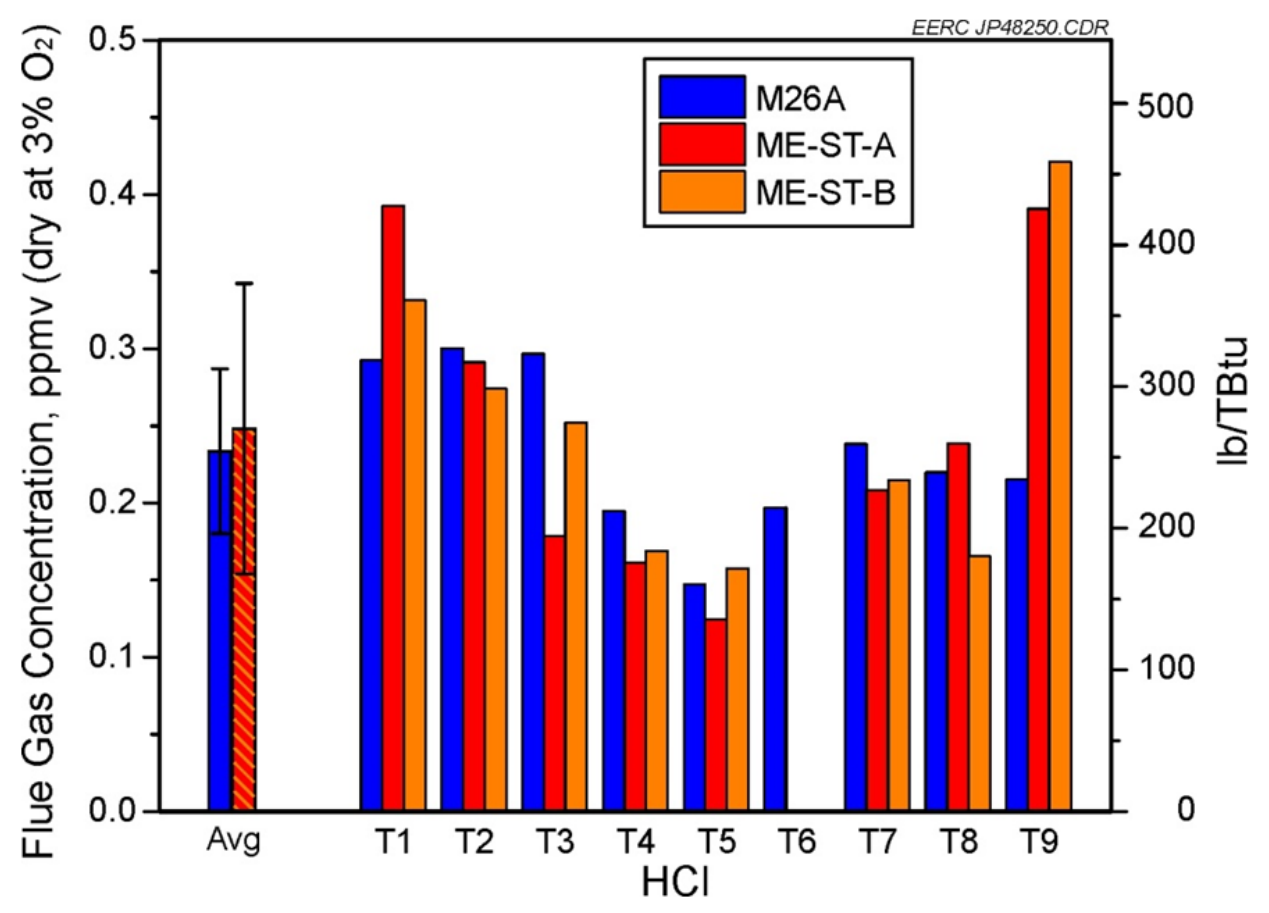

Figure 11. Comparison of sampling results for EPA M26A and the ME-ST-H method for $\mathrm{HCl}$ at Power Plant 1. 


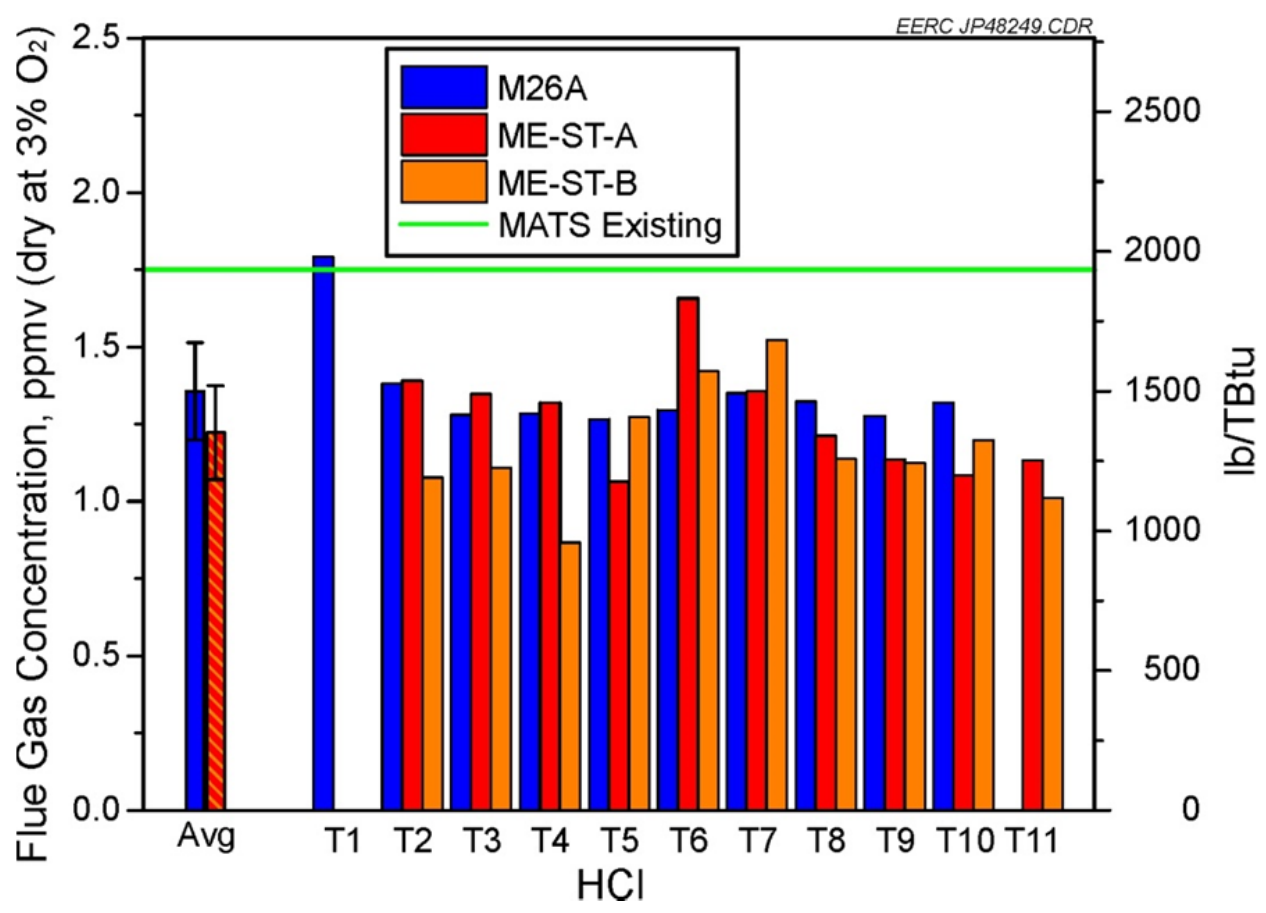

Figure 12. Comparison of sampling results for EPA M26A and the ME-ST-H method for $\mathrm{HCl}$ at Power Plant 2.

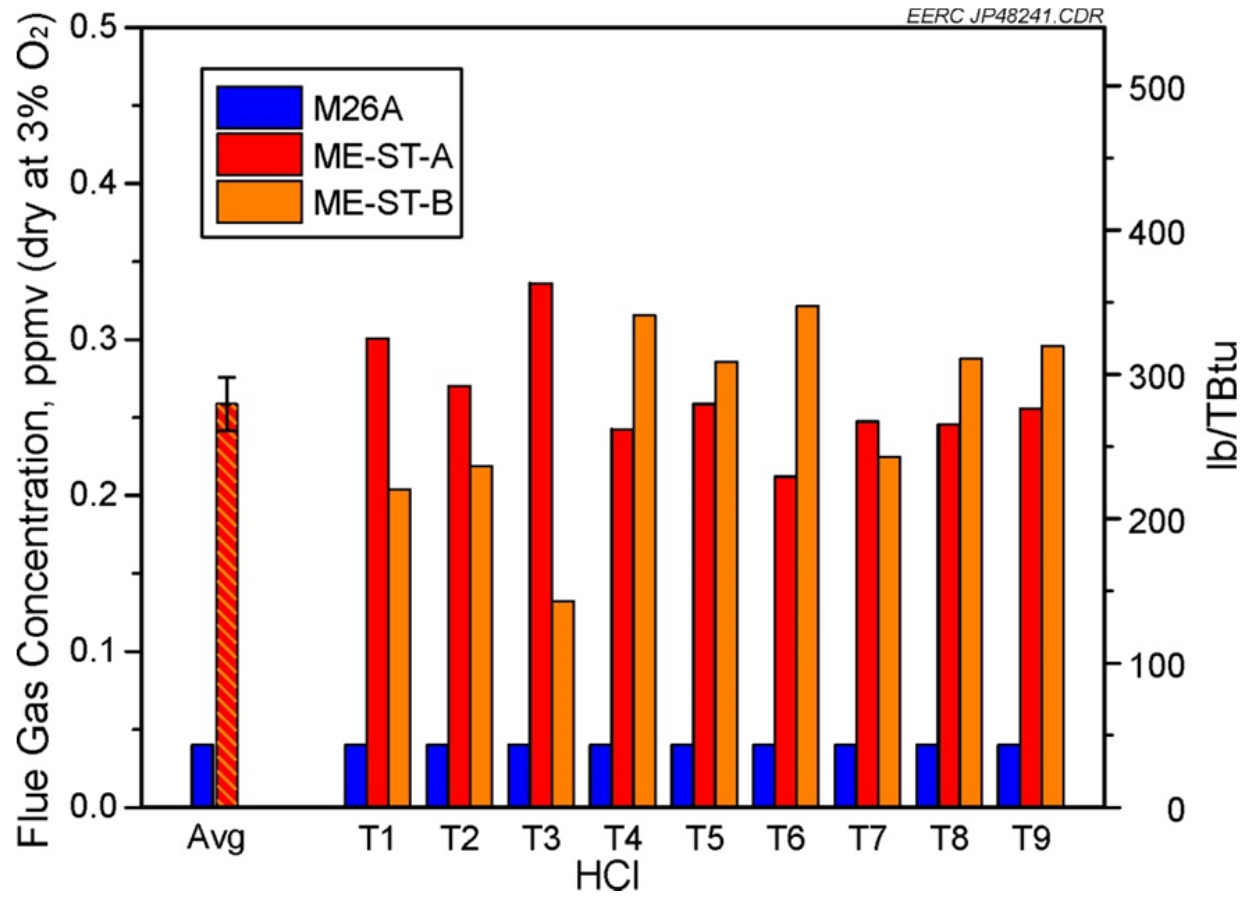

Figure 13. Comparison of sampling results for EPA M26A and the ME-ST-H method for $\mathrm{HCl}$ at Power Plant 3. 
At Plant 1 (Table 12 and Figure 11), the relative difference between the two methods was only $7.8 \%$ and the precision was very good. For Plant 2 (Table 13 and Figure 12), again the relative difference was very low-8.8\%. As will be discussed later, there were significant differences in precision between the two methods for Plant 2.

At Plant 3 (Table 14 and Figure 13), there appears to be a significant difference between the two methods for $\mathrm{HCl}$, with $\mathrm{M} 26 \mathrm{~A}$ measuring nondetect levels at a detection limit of 0.04 ppmv, while the ME-ST-H method measured detectable levels with an average concentration of 0.26 ppmv. However, the stack conditions for this unit include a stack temperature of approximately $140^{\circ} \mathrm{F}$, and the flue gas was oversaturated with moisture, resulting in waterdroplet formation. Under these conditions, isokinetic sampling is critical, but at the same time, it is nearly impossible to transfer the water droplets through the sampling probe without them coming into contact with the probe surfaces. The chloride trapped with the moisture in the probe is supposedly vaporized and converted to $\mathrm{HCl}$ and swept into the impingers according to the method, but this approach has been shown to be problematic (7). Therefore, it is believed that the M26A results are low because of difficulty in transferring the $\mathrm{HCl}$ to the impingers during sampling. As a result, it is meaningless to compare the ME-ST-H data to a problematic reference method.

\section{Trace Metal Results}

\section{Power Plant 1}

The sampling and analytical data for EPA M29 and the ME-ST-M method for Plant 1 are shown in Tables 15 and 16. Sb, As, Be, Cd, and Co were below the detection limits for both methods. Hg was well above detection limits, and all QA/QC criteria were easily met. For the EPA M29 samples, there were significant background levels in the blanks for $\mathrm{Cr}, \mathrm{Pb}, \mathrm{Mn}$, and Ni. These results are not valid according to the EPA M29 QC criterion (field blank correction above $30 \%$ is not allowed), but the blank-corrected results are included here for completeness. For the ME-ST-M method, high field blank values were a problem for $\mathrm{Cd}, \mathrm{Cr}, \mathrm{Pb}, \mathrm{Mn}$, and $\mathrm{Ni}$. These quality issues are indicated in the footnotes in Tables 15 and 16.

As was discussed previously, the ME-ST-M sampling that was carried out at Power Plant 1 was completed using the original traps, prior to modifications to lower the background levels. Because of this, the background levels were significant for nine of the 11 metals. The values for $\mathrm{Hg}$ and Se were well above detection limits, and all QA/QC criteria were easily met. It should be noted, as can be seen by the standard deviation, that the data for $\mathrm{Cd}, \mathrm{Cr}, \mathrm{Pb}, \mathrm{Mn}$, and $\mathrm{Ni}$ were quite variable, resulting in RSD values above $100 \%$, as might be expected for those metals with high background levels and low flue gas concentrations.

These concentration values were compared to the uncontrolled values from the coal to determine the capture of the metals in the bottom ash, ESPs, and wet FGD prior to the stack. These results are summarized in Table 17, which shows that the capture was greater than 95\%

for $\mathrm{Sb}, \mathrm{As}, \mathrm{Be}, \mathrm{Cd}, \mathrm{Cr}, \mathrm{Co}, \mathrm{Pb}, \mathrm{Mn}, \mathrm{Ni}$, and $\mathrm{Se}$. The metal known to be more volatile, $\mathrm{Hg}$, only showed $24 \%$ capture. 
Table 15. Plant 1 Flue Gas Trace Metal Concentrations as Measured Using EPA M29 $\left(\mu \mathrm{g} / \mathrm{dNm}^{3}\right.$ at $\left.3 \% \mathrm{O}_{2}\right)$

\begin{tabular}{lccccccccccc}
\hline Sample & $\mathrm{Sb}$ & $\mathrm{As}$ & $\mathrm{Be}$ & $\mathrm{Cd}$ & $\mathrm{Cr}$ & $\mathrm{Co}$ & $\mathrm{Pb}$ & $\mathrm{Mn}$ & $\mathrm{Hg}$ & $\mathrm{Ni}$ & $\mathrm{Se}$ \\
\hline M29-1 & $<2$ & $<0.6$ & $<0.2$ & $<0.2$ & $1.7^{\mathrm{b}}$ & $<0.5$ & $2.60^{\mathrm{a}}$ & $5.61^{\mathrm{a}}$ & 11.4 & $2.3^{\mathrm{b}}$ & $3.1^{\mathrm{b}}$ \\
M29-2 & $<2$ & $<0.4$ & $<0.2$ & $<0.2$ & $2.0^{\mathrm{b}}$ & $<0.4$ & $0.45^{\mathrm{b}}$ & $0.92^{\mathrm{b}}$ & 12.1 & $0.46^{\mathrm{b}}$ & $2.6^{\mathrm{b}}$ \\
M29-3 & $<2$ & $<0.6$ & $<0.2$ & $<0.2$ & $2.3^{\mathrm{b}}$ & $<0.4$ & $1.4^{\mathrm{b}}$ & $2.8^{\mathrm{b}}$ & 11.8 & $0.60^{\mathrm{b}}$ & $5.9^{\mathrm{b}}$ \\
M29-4 & $<2$ & $<0.4$ & $<0.2$ & $<0.2$ & $1.8^{\mathrm{b}}$ & $<0.4$ & $0.77^{\mathrm{b}}$ & $2.2^{\mathrm{b}}$ & 12.7 & $0.50^{\mathrm{b}}$ & $7.01^{\mathrm{a}}$ \\
M29-5 & $<2$ & $<0.4$ & $<0.2$ & $<0.2$ & $4.9^{\mathrm{b}}$ & $<0.5$ & $1.5^{\mathrm{b}}$ & $2.2^{\mathrm{b}}$ & 10.5 & $6.6^{\mathrm{b}}$ & $5.1^{\mathrm{b}}$ \\
M29-6 & $<2$ & $<0.4$ & $<0.2$ & $<0.2$ & $1.7^{\mathrm{b}}$ & $<0.4$ & $1.0^{\mathrm{b}}$ & $2.6^{\mathrm{b}}$ & 10.4 & $2.0^{\mathrm{b}}$ & $3.7^{\mathrm{b}}$ \\
M29-7 & $<2$ & $<0.6$ & $<0.2$ & $<0.2$ & $2.7^{\mathrm{b}}$ & $<0.4$ & $1.6^{\mathrm{b}}$ & $1.7^{\mathrm{b}}$ & 10.4 & $1.1^{\mathrm{b}}$ & $2.4^{\mathrm{b}}$ \\
M29-8 & $<2$ & $<0.6$ & $<0.2$ & $<0.2$ & $3.0^{\mathrm{b}}$ & $<0.4$ & $0.82^{\mathrm{b}}$ & $1.6^{\mathrm{b}}$ & 11.6 & $2.7^{\mathrm{b}}$ & $2.8^{\mathrm{b}}$ \\
M29-9 & $<2$ & $<0.5$ & $<0.2$ & $<0.2$ & $2.0^{\mathrm{b}}$ & $<0.4$ & $1.78^{\mathrm{a}}$ & $1.8^{\mathrm{b}}$ & 11.7 & $0.72^{\mathrm{b}}$ & $4.0^{\mathrm{b}}$ \\
\hline Average & $<2$ & $<0.5$ & $<0.2$ & $<0.2$ & $2.5^{\mathrm{b}}$ & $<0.4$ & $1.3^{\mathrm{b}}$ & $2.4^{\mathrm{b}}$ & 11.4 & $1.9^{\mathrm{b}}$ & $4.1^{\mathrm{b}}$ \\
Std. Dev. & & & & & 1.0 & & 0.7 & 1.3 & 0.8 & 2.0 & 1.6 \\
RSD, \% & & & & & 42 & & 49 & 55 & 7 & 103 & 39 \\
\hline
\end{tabular}

${ }^{\mathrm{a}}$ Valid blank-corrected value (blank $>10 \%$ but $<30 \%$ of sample value).

${ }^{\mathrm{b}}$ Invalid blank-corrected result (blank $>30 \%$ of sample value).

Table 16. Plant 1 Flue Gas Trace Metals Concentrations as Measured Using the ME-ST-M Method $\left(\mu \mathrm{g} / \mathrm{dNm}^{3}\right.$ at $\left.3 \% \mathrm{O}_{2}\right)$

\begin{tabular}{lccccccccccc}
\hline & $\mathrm{Sb}$ & $\mathrm{As}$ & $\mathrm{Be}$ & $\mathrm{Cd}$ & $\mathrm{Cr}$ & $\mathrm{Co}$ & $\mathrm{Pb}$ & $\mathrm{Mn}$ & $\mathrm{Hg}$ & $\mathrm{Ni}$ & $\mathrm{Se}$ \\
\hline $\mathrm{TM}-1$ & $<0.05^{\mathrm{b}}$ & $<0.3^{\mathrm{b}}$ & $<0.05^{\mathrm{b}}$ & $<0.05^{\mathrm{b}}$ & $1.3^{\mathrm{a}, \mathrm{c}}$ & $0.73^{\mathrm{a}, \mathrm{c}}$ & $<0.05^{\mathrm{b}}$ & $65^{\mathrm{a}}$ & 9.14 & $<0.1^{\mathrm{b}}$ & 2.06 \\
TM-2 & $<0.05^{\mathrm{b}}$ & $<0.3^{\mathrm{b}}$ & $<0.05^{\mathrm{b}}$ & $<0.05^{\mathrm{b}}$ & $<0.05^{\mathrm{b}}$ & $<0.3^{\mathrm{b}}$ & $1.6^{\mathrm{a}, \mathrm{c}}$ & $6.7^{\mathrm{a}, \mathrm{c}}$ & 10.3 & $9.9^{\mathrm{a}, \mathrm{c}}$ & 3.49 \\
$\mathrm{TM}-3$ & $<0.05^{\mathrm{b}}$ & $<0.3^{\mathrm{b}}$ & $0.05^{\mathrm{a}}$ & $0.28^{\mathrm{a}, \mathrm{c}}$ & $0.67^{\mathrm{a}, \mathrm{c}}$ & $<0.3^{\mathrm{b}}$ & $1.4^{\mathrm{a}, \mathrm{c}}$ & $7.3^{\mathrm{a}}$ & 9.67 & $4.5^{\mathrm{a}, \mathrm{c}}$ & 3.21 \\
$\mathrm{TM}-4$ & $<0.05^{\mathrm{b}}$ & $<0.2^{\mathrm{b}}$ & $0.07^{\mathrm{a}, \mathrm{c}}$ & $1.1^{\mathrm{a}}$ & $<0.05^{\mathrm{b}}$ & $<0.2^{\mathrm{b}}$ & $13^{\mathrm{a}}$ & $13^{\mathrm{a}, \mathrm{c}}$ & 9.96 & $4.8^{\mathrm{a}, \mathrm{c}}$ & 5.44 \\
$\mathrm{TM}-5$ & $<0.05^{\mathrm{b}}$ & $<0.2^{\mathrm{b}}$ & $<0.05^{\mathrm{b}}$ & $0.23^{\mathrm{a}, \mathrm{c}}$ & $<0.05^{\mathrm{b}}$ & $<0.2^{\mathrm{b}}$ & $2.5^{\mathrm{a}, \mathrm{c}}$ & $2.4^{\mathrm{a}, \mathrm{c}}$ & 8.86 & $<0.1^{\mathrm{b}}$ & $3.66^{\mathrm{c}}$ \\
$\mathrm{TM}-6$ & $<0.05^{\mathrm{b}}$ & $<0.2^{\mathrm{b}}$ & $<0.05^{\mathrm{b}}$ & $1.8^{\mathrm{a}, \mathrm{c}}$ & $3.9^{\mathrm{a}}$ & $<0.2^{\mathrm{b}}$ & $16^{\mathrm{a}, \mathrm{c}}$ & $14^{\mathrm{a}}$ & 9.04 & $<0.1^{\mathrm{b}}$ & 2.67 \\
TM-7 & $<0.05^{\mathrm{b}}$ & $<0.2^{\mathrm{b}}$ & $<0.05^{\mathrm{b}}$ & $0.43^{\mathrm{a}, \mathrm{c}}$ & $1.6^{\mathrm{a}, \mathrm{c}}$ & $<0.2^{\mathrm{b}}$ & $3.5^{\mathrm{a}, \mathrm{c}}$ & $<0.05^{\mathrm{b}}$ & 8.78 & $<0.1^{\mathrm{b}}$ & 1.46 \\
TM-8 & $<0.05^{\mathrm{b}}$ & $<0.2^{\mathrm{b}}$ & $<0.05^{\mathrm{b}}$ & $2.9^{\mathrm{a}, \mathrm{c}}$ & $<0.05^{\mathrm{b}}$ & $<0.2^{\mathrm{b}}$ & $30^{\mathrm{a}, \mathrm{c}}$ & $3.5^{\mathrm{a}, \mathrm{c}}$ & 8.69 & $<0.1^{\mathrm{b}}$ & 1.62 \\
TM-9 & $<0.05^{\mathrm{b}}$ & $<0.2^{\mathrm{b}}$ & $<0.05^{\mathrm{b}}$ & $1.6^{\mathrm{a}, \mathrm{c}}$ & $0.61^{\mathrm{a}, \mathrm{c}}$ & $<0.2^{\mathrm{b}}$ & $17^{\mathrm{a}, \mathrm{c}}$ & $3.9^{\mathrm{a}, \mathrm{c}}$ & 9.52 & $6.6^{\mathrm{a}, \mathrm{c}}$ & 2.89 \\
\hline Average & $<0.05^{\mathrm{b}}$ & $<0.2^{\mathrm{b}}$ & $<0.05^{\mathrm{b}}$ & $0.94^{\mathrm{a}, \mathrm{c}}$ & $0.91^{\mathrm{a}, \mathrm{c}}$ & $<0.3^{\mathrm{b}}$ & $9.3^{\mathrm{a}, \mathrm{c}}$ & $13^{\mathrm{a}, \mathrm{c}}$ & 9.33 & $2.9^{\mathrm{a}, \mathrm{c}}$ & 2.95 \\
Std. Dev. & & & & 1.0 & 1.2 & & 10.1 & 20 & 0.57 & 3.7 & 1.2 \\
RSD, \% & & & 106 & 137 & & 108 & 155 & 6 & 126 & 41 \\
\hline
\end{tabular}

Table 17. Trace Metal Capture at Plant 1 Using EPA M29 and ME-ST-M Data

\begin{tabular}{l|ccccccccccc}
\hline & \multicolumn{10}{|c}{$\mu \mathrm{g} / \mathrm{dNm}^{3}$ at $3 \% \mathrm{O}_{2}$} \\
Method & $\mathrm{Sb}$ & $\mathrm{As}$ & $\mathrm{Be}$ & $\mathrm{Cd}$ & $\mathrm{Cr}$ & $\mathrm{Co}$ & $\mathrm{Pb}$ & $\mathrm{Mn}$ & $\mathrm{Hg}$ & $\mathrm{Ni}$ & $\mathrm{Se}$ \\
\hline Uncontrolled & 121 & 1802 & 99 & 22 & 2409 & 350 & 711 & 10,776 & 15.0 & 1967 & 91 \\
\hline EPA M29, & $<2$ & $<0.5$ & $<0.2$ & $<0.2$ & $2.5^{\mathrm{a}}$ & $<0.4$ & $1^{\mathrm{a}}$ & $2^{\mathrm{a}}$ & 11.4 & $1.9^{\mathrm{a}}$ & $4^{\mathrm{a}}$ \\
Capture, \% & $>99$ & $>99$ & $>99$ & $>99$ & 99.9 & $>99$ & 99.8 & 100 & 24.2 & 99.9 & 95.5 \\
\hline ME-ST-M & $<0.05^{\mathrm{b}}$ & $<0.2^{\mathrm{b}}$ & $<0.05^{\mathrm{b}}$ & $0.94^{\mathrm{a}, \mathrm{c}}$ & $0.9^{\mathrm{a}, \mathrm{c}}$ & $<0.3^{\mathrm{b}}$ & $9.3^{\mathrm{a}, \mathrm{c}}$ & $13^{\mathrm{a}, \mathrm{c}}$ & 9.33 & $2.9^{\mathrm{a}, \mathrm{c}}$ & 2.95 \\
Capture, \% & $>99$ & $>99$ & $>99$ & 95.7 & 99.9 & $>99$ & 99 & 98.7 & 37.8 & 99.9 & 96.8 \\
\hline \\
\hline a Blank-corrected (blank $>30 \%$ of sample value). \\
b Blank-corrected to below detection limit. \\
${ }^{\mathrm{c}}$ RD for duplicate traps $>20 \%$.
\end{tabular}


A summary of the metal results for Plant 1 is shown in Figure 14. It should be noted that graphical comparison between the two methods for each of the trace metals and a more detailed explanation of the results are provided in Appendix C. For both methods, $\mathrm{Sb}, \mathrm{As}, \mathrm{Be}$, and $\mathrm{Co}$ were below detection limits. For each of those metals, the ME-ST-M method has a lower method detection limit than EPA M29. For Sb, Be, Cd, Cr, and Co, the EPA M29 detection limit is not sufficiently low to meet the MATS limits for new/reconstructed units for these sampling conditions. As can be seen in Figure 14, only $\mathrm{Hg}$ was above the MATS limit for existing lowrank coal-fired units $\left(5.42 \mu \mathrm{g} / \mathrm{dNm}^{3}\right)$ based on EPA M29. The ME-ST-M tests at this site produced elevated blanks for nine of the 11 metals ( $\mathrm{Hg}$ and Se were the exception). As a result, the standard deviations of the data, especially for $\mathrm{Cd}, \mathrm{Cr}, \mathrm{Pb}, \mathrm{Mn}$, and $\mathrm{Ni}$, were very high, resulting in RSD values above $100 \%$. Therefore, it was clear that it was necessary to reduce the blank concentrations for the targeted trace metals for future testing. Improved sorbent and plug materials were identified and used in subsequent field tests. In addition, M29 had RSD near $100 \%$ as well. To reduce the variability of the EPA M29 sampling method, new glassware and reagents were purchased prior to Plant 2 testing.

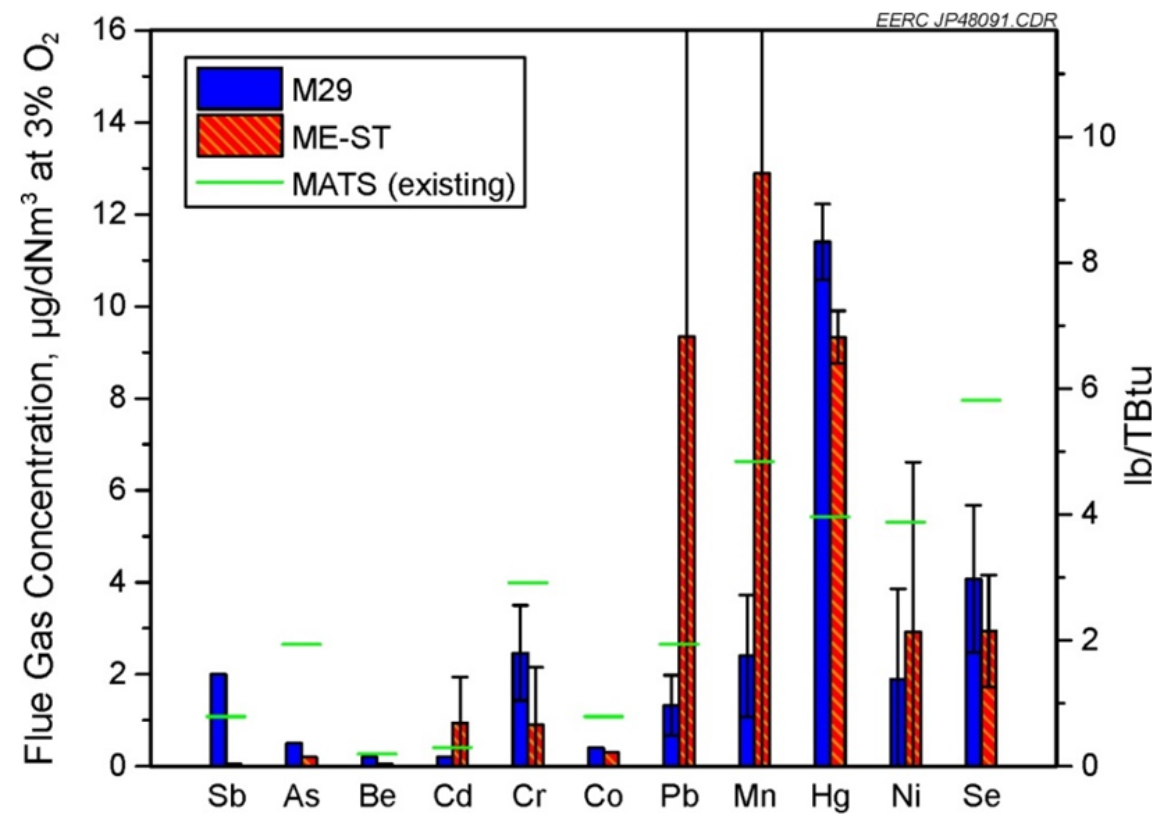

Figure 14. Comparison of sampling results for EPA M29 and ME-ST-M method for Plant 1.

\section{Power Plant 2}

The sampling and analytical data for Plant 2 are provided in Tables 18 and 19. The data show that $\mathrm{Sb}, \mathrm{Be}$, and $\mathrm{Cd}$ values were below the detection limits for EPA M29, but all of the trace metals of interest were above the detection limits for the ME-ST-M method. As stated previously, new glassware was purchased prior to the testing at Plant 2, and as a result, the M29 blank concentrations were much better for Plant 2 than Plant 1 . However, $\mathrm{Cr}, \mathrm{Mn}$, and Ni still were not able to meet the method QA/QC requirements as indicated by the footnote in Table 18 . 
Table 18. Plant 2 Flue Gas Trace Metal Concentrations as Measured Using EPA M29 $\left(\mu \mathrm{g} / \mathrm{dNm}^{3}\right.$ at $\left.3 \% \mathrm{O}_{2}\right)$

\begin{tabular}{lccccccccccc}
\hline Sample & $\mathrm{Sb}$ & $\mathrm{As}$ & $\mathrm{Be}$ & $\mathrm{Cd}$ & $\mathrm{Cr}$ & $\mathrm{Co}$ & $\mathrm{Pb}$ & $\mathrm{Mn}$ & $\mathrm{Hg}$ & $\mathrm{Ni}$ & $\mathrm{Se}$ \\
\hline M29-1 & $<1$ & 8.60 & $<0.2$ & $<0.2$ & $4.40^{\mathrm{a}}$ & 0.450 & 4.44 & $17^{\mathrm{b}}$ & 6.60 & $3.9^{\mathrm{b}}$ & 34.6 \\
M29-2 & $<2$ & 9.07 & $<0.2$ & $<0.2$ & $4.86^{\mathrm{a}}$ & 0.402 & 3.97 & $15^{\mathrm{b}}$ & 8.76 & $2.8^{\mathrm{b}}$ & 52.8 \\
M29-3 & $<1$ & 7.57 & $<0.3$ & $<0.2$ & $7.8^{\mathrm{b}}$ & 1.39 & 4.57 & $18^{\mathrm{b}}$ & 8.97 & $3.8^{\mathrm{b}}$ & 16.4 \\
M29-4 & $<2$ & 11.8 & $<0.2$ & 0.4 & $3.5^{\mathrm{b}}$ & 0.533 & 4.61 & $18^{\mathrm{b}}$ & 9.17 & $2.3^{\mathrm{b}}$ & 6.25 \\
M29-5 & $<2$ & 12.8 & $<0.3$ & $<0.3$ & $5.6^{\mathrm{b}}$ & 0.654 & 13.1 & $22^{\mathrm{b}}$ & 9.28 & $3.9^{\mathrm{b}}$ & 24.9 \\
M29-6 & $<2$ & 10.5 & $<0.2$ & $<0.3$ & $2.6^{\mathrm{b}}$ & 0.431 & 3.35 & $19^{\mathrm{b}}$ & 8.53 & $2.6^{\mathrm{b}}$ & 13.9 \\
M29-7 & $<2$ & 10.6 & $<0.2$ & $<0.2$ & $3.4^{\mathrm{b}}$ & 0.580 & 5.37 & $16^{\mathrm{b}}$ & 8.54 & $2.2^{\mathrm{b}}$ & 13.9 \\
M29-8 & $<2$ & 11.9 & $<0.2$ & $<0.2$ & $3.4^{\mathrm{b}}$ & 0.512 & 8.03 & $18^{\mathrm{b}}$ & 7.52 & $1.9^{\mathrm{b}}$ & 40.8 \\
M29-9 & $<2$ & 12.8 & $<0.3$ & $<0.3$ & $4.4^{\mathrm{b}}$ & 0.628 & 7.67 & $16^{\mathrm{b}}$ & 6.68 & $2.2^{\mathrm{b}}$ & 20.6 \\
M29-10 & $<2$ & 11.9 & $<0.2$ & $<0.2$ & $3.7^{\mathrm{b}}$ & 0.469 & 5.66 & $18^{\mathrm{b}}$ & 7.22 & $2.1^{\mathrm{b}}$ & 16.9 \\
\hline Average & $<2$ & 10.7 & $<0.2$ & $<0.3$ & $4.4^{\mathrm{b}}$ & 0.605 & 6.08 & $18^{\mathrm{b}}$ & 8.13 & $2.8^{\mathrm{b}}$ & 24.1 \\
Std. Dev. & - & 1.8 & - & - & 1.5 & 0.287 & 2.90 & 2 & 1.03 & 0.8 & 14.4 \\
RSD, \% & - & 17 & - & - & 34 & 48 & 48 & 11 & 13 & 29 & 60 \\
\hline
\end{tabular}

${ }^{\mathrm{a}}$ Valid blank-corrected value (blank $>10 \%$ but $<30 \%$ of sample value).

${ }^{\mathrm{b}}$ Invalid blank-corrected result (blank $>30 \%$ of sample value).

Table 19. Plant 2 Flue Gas Trace Metal Concentrations as Measured Using ME-ST-M $\left(\mu \mathrm{g} / \mathrm{dNm}^{3}\right.$ at $\left.3 \% \mathrm{O}_{2}\right)$

\begin{tabular}{lccccccccccc}
\hline & $\mathrm{Sb}$ & $\mathrm{As}$ & $\mathrm{Be}$ & $\mathrm{Cd}$ & $\mathrm{Cr}$ & $\mathrm{Co}$ & $\mathrm{Pb}$ & $\mathrm{Mn}$ & $\mathrm{Hg}$ & $\mathrm{Ni}$ & $\mathrm{Se}$ \\
\hline TM-3 & 0.51 & 6.82 & $0.10^{\mathrm{b}}$ & $0.05^{\mathrm{b}}$ & $2.80^{\mathrm{b}}$ & $0.43^{\mathrm{b}}$ & $8.55^{\mathrm{b}}$ & $11.8^{\mathrm{b}}$ & 9.67 & $2.21^{\mathrm{b}, \mathrm{c}}$ & 9.86 \\
TM-4 & $0.50^{\mathrm{a}}$ & 7.55 & $0.11^{\mathrm{b}}$ & $0.44^{\mathrm{b}, \mathrm{c}}$ & $22^{\mathrm{c}}$ & 0.59 & $8.93^{\mathrm{b}}$ & $13.2^{\mathrm{b}}$ & 9.72 & $18^{\mathrm{c} \mathrm{c}}$ & 9.52 \\
TM-5 & 0.53 & 7.71 & $0.12^{\mathrm{b}}$ & $1.2^{\mathrm{c}}$ & 2.95 & 0.50 & $13.6^{\mathrm{b}}$ & $13.1^{\mathrm{b}, \mathrm{c}}$ & 9.73 & $1.24^{\mathrm{b}, \mathrm{c}}$ & 7.39 \\
TM-6 & $0.47^{\mathrm{a}}$ & 7.67 & $0.10^{\mathrm{b}}$ & $3.0^{\mathrm{c}, \mathrm{c}}$ & $3.73^{\mathrm{b}, \mathrm{c}}$ & 0.48 & $24.1^{\mathrm{b}}$ & $12.2^{\mathrm{b}, \mathrm{c}}$ & 9.26 & $1.12^{\mathrm{b}, \mathrm{c}}$ & 6.26 \\
TM-7 & 0.55 & 9.35 & $0.12^{\mathrm{a}, \mathrm{c}}$ & $0.16^{\mathrm{b}, \mathrm{c}}$ & $3.96^{\mathrm{b}}$ & 0.59 & $12.6^{\mathrm{b}, \mathrm{c}}$ & $11.3^{\mathrm{b}, \mathrm{c}}$ & 9.22 & $3.37^{\mathrm{b}}$ & 7.41 \\
TM-8 & 0.71 & 9.28 & $0.13^{\mathrm{a}}$ & $0.06^{\mathrm{b}}$ & $4.53^{\mathrm{b}}$ & 0.48 & $22.2^{\mathrm{b} \mathrm{c}}$ & $5.00^{\mathrm{b}}$ & 8.31 & $3.97^{\mathrm{b}}$ & 8.97 \\
TM-9 & 0.78 & 10.3 & $0.13^{\mathrm{a}}$ & $0.14^{\mathrm{b}, \mathrm{c}}$ & $4.19^{\mathrm{b}}$ & 0.67 & $19.0^{\mathrm{b}}$ & $6.73^{\mathrm{b}}$ & 7.90 & $2.11^{\mathrm{b}, \mathrm{c}}$ & 9.01 \\
TM-10 & 0.68 & 10.5 & $0.10^{\mathrm{a}}$ & $0.34^{\mathrm{b}, \mathrm{c}}$ & $4.79^{\mathrm{b}}$ & 0.58 & $16.6^{\mathrm{b}}$ & $6.18^{\mathrm{b}}$ & 7.99 & $2.69^{\mathrm{b}, \mathrm{c}}$ & 8.52 \\
TM-11 & 0.50 & 7.11 & $0.10^{\mathrm{b}}$ & $0.08^{\mathrm{b}}$ & $2.37^{\mathrm{b}}$ & 0.36 & $13.8^{\mathrm{b}}$ & $4.10^{\mathrm{b}}$ & 8.26 & $1.85^{b^{, c}}$ & 6.74 \\
\hline Average & 0.58 & 8.48 & $0.11^{\mathrm{b}}$ & $0.62^{\mathrm{b}}$ & $5.74^{\mathrm{b}}$ & 0.52 & $15.5^{\mathrm{b}}$ & $9.3^{\mathrm{b}}$ & 8.90 & $4.02^{\mathrm{b}}$ & 8.19 \\
Std. Dev. & 0.11 & 1.40 & 0.01 & 0.98 & 6.30 & 0.09 & 5.5 & 3.7 & 0.77 & 5.18 & 1.28 \\
RSD, \% & 19 & 17 & 11 & 159 & 110 & 18 & 35 & 40 & 9 & 129 & 16 \\
\hline
\end{tabular}

${ }^{\text {a }}$ Valid blank correction (blank $>10 \%$ but $<30 \%$ of sample value).

${ }^{\mathrm{b}}$ Invalid blank correction (blank $>30 \%$ of sample value).

${ }^{\mathrm{c}} \mathrm{RD}$ for duplicate traps $>20 \%$.

The ME-ST-M sampling at Plant 2 used the improved traps, so background levels were significantly lower than at Plant 1 . Even so, the background levels were measurable, i.e., above detection limits, for eight of the 11 metals. All metals were above detection limits after background correction. Metals with significant blank levels included $\mathrm{Be}, \mathrm{Cd}, \mathrm{Cr}, \mathrm{Pb}, \mathrm{Mn}$, and $\mathrm{Ni}$ (as shown by the footnotes in Table 20). Sb, As, $\mathrm{Hg}, \mathrm{Co}$, and Se were above detection limits, and 
Table 20. Trace Metal Capture at Plant 2 Using EPA M29 and ME-ST-M Data

\begin{tabular}{l|ccccccccccc}
\hline \multirow{2}{*}{ Method } & \multicolumn{1}{|c}{$\mathrm{Sb}$} & $\mathrm{As}$ & $\mathrm{Be}$ & $\mathrm{Cd}$ & $\mathrm{Cr}$ & $\mathrm{Co}$ & $\mathrm{Pb}$ & $\mathrm{Mn}$ & $\mathrm{Hg}$ & $\mathrm{Ni}$ & $\mathrm{Se}$ \\
\hline Uncontrolled & 35 & 414 & 17.8 & 6.44 & 1,157 & 124 & 200 & 4,935 & 9.94 & 741 & 68 \\
\hline EPA & $<2$ & 10.7 & $<0.2$ & $<0.3$ & $4.4^{*}$ & 0.52 & $6.08^{*}$ & $18^{*}$ & 8.13 & $2.8^{*}$ & 24.1 \\
M29 & & & & & & & & & & & \\
Capture, \% & $>95$ & 97.4 & $>99$ & $>96$ & 99.6 & 99.5 & 97.0 & 99.6 & 18.2 & 99.6 & 64.8 \\
\hline ME-ST-M & 0.58 & 8.48 & $0.11^{*}$ & $0.62^{*}$ & $5.74^{*}$ & 0.605 & $15.5^{*}$ & $9.3^{*}$ & 8.90 & $4.02^{*}$ & 8.19 \\
Capture, \% & 98.3 & 98.0 & 99.4 & 90.4 & 99.5 & 99.5 & 92.2 & 99.8 & 10.5 & 99.5 & 93.4 \\
\hline
\end{tabular}

* Invalid blank correction (blank $>30 \%$ of sample value).

all QA/QC criteria were easily met (with the exception of several Co and Se samples, as is discussed in the QA/QC section of this report). $\mathrm{Cd}, \mathrm{Cr}$, and $\mathrm{Ni}$ concentrations were quite variable, and each of these metals data sets had RSD values above $100 \%$, as might be expected with high background levels and low flue gas concentrations.

Table 20 compares the stack gas concentrations as measured by EPA M29 and the ME-ST$\mathrm{M}$ method to the uncontrolled flue gas concentrations calculated from the coal composition to determine the capture of the metals in the bottom ash and ESPs prior to the stack. EPA M29 showed greater than $95 \%$ removal for all the trace metals, with the exception of the more volatile trace elements $\mathrm{Hg}$ and Se. The same was true for the results of the ME-ST-M method, except capture of $\mathrm{Cd}$ and $\mathrm{Pb}$ were also calculated to be slightly less than $95 \%$.

A summary of the metals results data for Plant 2 is shown in Figure 15 (it should be noted that graphical comparison between the two methods for each of the trace metals and a more detailed explanation of the results are provided in Appendix $\mathrm{C}$ ). For both methods, $\mathrm{As}, \mathrm{Cr}, \mathrm{Pb}$, $\mathrm{Mn}, \mathrm{Hg}$, and Se were above the MATS limits for the unit. Be, Co, and Ni were below the MATS limits. For Sb, the ME-ST-M method shows the emissions are below the MATS limit, while EPA M29 is not sensitive enough to make the determination. Cd is near the MATS limit; results were above the limit by the ME-ST-M method and were nondetect for EPA M29.

\section{Power Plant 3}

The average valid results from the EPA M29 and ME-ST-M sampling methods at Plant 3 are presented in Tables 21 and 22. Only Sb was below the detection limits for EPA M29. However, $\mathrm{Cr}, \mathrm{Mn}$, and $\mathrm{Ni}$ had background blanks that were $>30 \%$ of the measured value, resulting in an invalid sample. Although the measured values were all above the detection limits of the ME-ST-M method, after each of the trace metals was corrected for the blank, $\mathrm{Cd}, \mathrm{Cr}, \mathrm{Pb}$, and $\mathrm{Ni}$ were below the detection limits. The only trace metal having a blank correction $>30 \%$ using the ME-ST-M method (an invalid result, as shown in the footnotes of Table 22) was Mn. However, $\mathrm{Cd}, \mathrm{Pb}$, and $\mathrm{Ni}$ were quite variable, with each having an $\mathrm{RSD}$ value above $100 \%$, as might be expected with high background levels and low flue gas concentrations. 


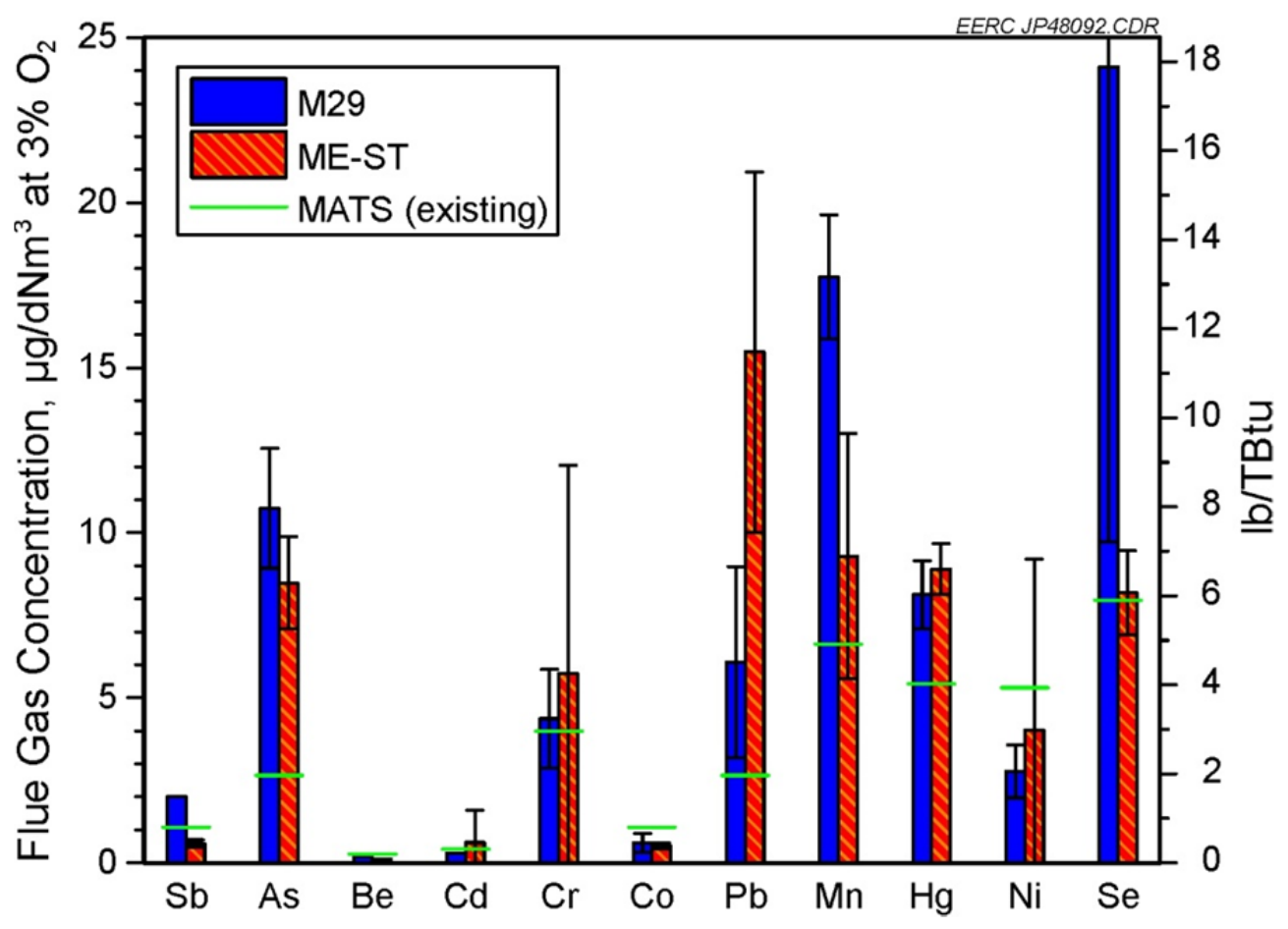

Figure 15. Comparison of sampling results for EPA M29 and the ME-ST-M method for Plant 2.

Table 21. Plant 3 Flue Gas Trace Metal Concentrations as Measured Using EPA M29 $\left(\mu \mathrm{g} / \mathrm{dNm}^{3}\right.$ at $\left.3 \% \mathrm{O}_{2}\right)$

\begin{tabular}{lccccccccccc}
\hline Sample & $\mathrm{Sb}$ & $\mathrm{As}$ & $\mathrm{Be}$ & $\mathrm{Cd}$ & $\mathrm{Cr}$ & $\mathrm{Co}$ & $\mathrm{Pb}$ & $\mathrm{Mn}$ & $\mathrm{Hg}$ & $\mathrm{Ni}$ & $\mathrm{Se}$ \\
\hline $\mathrm{M} 29-1$ & $<1$ & 9.49 & 0.396 & 0.611 & $2.9^{\mathrm{a}}$ & 0.939 & 3.81 & $69^{\mathrm{a}}$ & 3.20 & $8.9^{\mathrm{a}}$ & 8.57 \\
M29-2 & $<1$ & 5.73 & 0.268 & 0.462 & $3.9^{\mathrm{a}}$ & 0.811 & 2.30 & $69^{\mathrm{a}}$ & 3.62 & $5.7^{\mathrm{a}}$ & 8.07 \\
M29-3 & $<1$ & 7.08 & 0.323 & 0.492 & $5.01^{\mathrm{b}}$ & 0.862 & 2.48 & $77^{\mathrm{a}}$ & 4.10 & $5.3^{\mathrm{a}}$ & 8.72 \\
M29-4 & $<1$ & 9.36 & 0.337 & 0.561 & $6.6^{\mathrm{a}}$ & 0.921 & 2.58 & $90^{\mathrm{a}}$ & 3.04 & $6.4^{\mathrm{a}}$ & 8.33 \\
M29-5 & $<1$ & 8.77 & 0.312 & 0.423 & $6.37^{\mathrm{b}}$ & 0.896 & 2.52 & $86^{\mathrm{a}}$ & 3.35 & $5.5^{\mathrm{a}}$ & 8.10 \\
M29-6 & $<1$ & 7.08 & 0.301 & 0.473 & $3.0^{\mathrm{a}}$ & 0.791 & 2.51 & 60.4 & 4.33 & $2.4^{\mathrm{a}}$ & 7.96 \\
M29-7 & $<1$ & 8.30 & 0.342 & 0.441 & $4.1^{\mathrm{a}}$ & 0.826 & 2.34 & $65^{\mathrm{a}}$ & 4.08 & $3.1^{\mathrm{a}}$ & 7.72 \\
M29-8 & $<1$ & 9.62 & 0.369 & 0.462 & $3.5^{\mathrm{a}}$ & 0.879 & 2.97 & 70.5 & 4.20 & $2.2^{\mathrm{a}}$ & 7.68 \\
M29-11 & $<1$ & 11.7 & 0.426 & 0.50 & $3.3^{\mathrm{a}}$ & 0.980 & 3.10 & 74.6 & 4.37 & $2.2^{\mathrm{a}}$ & 7.83 \\
\hline Average & $<1$ & 8.57 & 0.342 & 0.492 & $4.3^{\mathrm{a}}$ & 0.878 & 2.73 & $73^{\mathrm{b}}$ & 3.81 & $4.6^{\mathrm{a}}$ & 8.11 \\
Std. & - & 1.78 & 0.049 & 0.060 & 1.4 & 0.062 & 0.48 & 10 & 0.51 & 2.3 & 0.36 \\
RSD, \% & - & 21 & 14 & 12 & 32 & 7 & 18 & 13 & 13 & 50 & 4 \\
\hline
\end{tabular}

${ }^{\mathrm{a}}$ Invalid blank-corrected result (blank $>30 \%$ of sample value).

${ }^{\mathrm{b}}$ Valid blank-corrected value (blank $>10 \%$ but $<30 \%$ of sample value). 
Table 22. Plant 3 Flue Gas Trace Metals Concentrations as Measured Using ME-ST-M $\left(\mu \mathrm{g} / \mathrm{dNm}^{3}\right.$ at $\left.3 \% \mathrm{O}_{2}\right)$

\begin{tabular}{lccccccccccc}
\hline & $\mathrm{Sb}$ & $\mathrm{As}$ & $\mathrm{Be}$ & $\mathrm{Cd}$ & $\mathrm{Cr}$ & $\mathrm{Co}$ & $\mathrm{Pb}$ & $\mathrm{Mn}$ & $\mathrm{Hg}$ & $\mathrm{Ni}$ & $\mathrm{Se}$ \\
\hline TM-1 & $0.833^{\mathrm{a}}$ & 25.1 & $0.885^{\mathrm{a}}$ & $0.19^{\mathrm{c}}$ & $12^{\mathrm{b}}$ & $1.39^{\mathrm{b}}$ & $2.7^{\mathrm{b}}$ & $158^{\mathrm{a}}$ & 2.63 & $4.4^{\mathrm{c}, \mathrm{d}}$ & 5.61 \\
TM-2 & $0.324^{\mathrm{a}}$ & $3.45^{\mathrm{a}}$ & $0.626^{\mathrm{a}, \mathrm{d}}$ & $4.0^{\mathrm{c}, \mathrm{d}}$ & $44.8^{\mathrm{a}, \mathrm{d}}$ & $1.18^{\mathrm{a}, \mathrm{d}}$ & $33.3^{\mathrm{d}}$ & 126 & 3.67 & $83.1^{\mathrm{d}}$ & 4.70 \\
TM-3 & $0.432^{\mathrm{a}}$ & $9.38^{\mathrm{a}, \mathrm{d}}$ & $0.362^{\mathrm{a}, \mathrm{d}}$ & $0.13^{\mathrm{b}, \mathrm{d}}$ & $59^{\mathrm{b}, \mathrm{d}}$ & $1.38^{\mathrm{a}, \mathrm{d}}$ & $1.3^{\mathrm{b}}$ & $117^{\mathrm{a}, \mathrm{d}}$ & 4.47 & $39.4^{\mathrm{a}, \mathrm{d}}$ & 5.78 \\
TM-4 & $0.666^{\mathrm{a}}$ & 11.8 & $0.463^{\mathrm{a}}$ & $0.19^{\mathrm{b}}$ & $9.30^{\mathrm{a}}$ & $1.62^{\mathrm{a}}$ & $0.88^{\mathrm{c}}$ & 165 & 2.97 & $4.7^{\mathrm{c}, \mathrm{d}}$ & 6.91 \\
TM-5 & $0.579^{\mathrm{a}}$ & 9.03 & $0.388^{\mathrm{a}}$ & $0.076^{\mathrm{c}, \mathrm{d}}$ & 52.2 & $1.69^{\mathrm{a}}$ & $1.4^{\mathrm{c}}$ & 161 & 3.32 & $41^{\mathrm{c}, \mathrm{d}}$ & 6.07 \\
TM-6 & $0.650^{\mathrm{a}}$ & 11.2 & $0.462^{\mathrm{a}}$ & $0.19^{\mathrm{b}, \mathrm{d}}$ & $9.80^{\mathrm{a}}$ & $1.35^{\mathrm{a}, \mathrm{d}}$ & $2.0^{\mathrm{c}}$ & $148^{\mathrm{a}}$ & 4.53 & $7.7^{\mathrm{c}, \mathrm{d}}$ & 5.90 \\
TM-7 & $0.502^{\mathrm{a}}$ & 7.8 & $0.364^{\mathrm{a}}$ & $<0.05^{\mathrm{c}}$ & $15^{\mathrm{c}, \mathrm{d}}$ & $0.98^{\mathrm{b}, \mathrm{d}}$ & $7.5^{\mathrm{c}, \mathrm{d}}$ & $88.8^{\mathrm{a}, \mathrm{d}}$ & 4.06 & $5.5^{\mathrm{c}, \mathrm{d}}$ & 5.37 \\
TM-8 & $0.567^{\mathrm{a}}$ & $10.0^{\mathrm{d}}$ & $0.430^{\mathrm{a}}$ & $0.22^{\mathrm{b}, \mathrm{d}}$ & $50^{\mathrm{b}, \mathrm{d}}$ & $1.60^{\mathrm{a}}$ & $1.8^{\mathrm{c}}$ & $131^{\mathrm{b}}$ & 3.79 & $31^{\mathrm{c}, \mathrm{d}}$ & 5.10 \\
TM-11 & $0.779^{\mathrm{a}, \mathrm{d}}$ & 11.9 & $0.605^{\mathrm{a}}$ & $3.8^{\mathrm{c}, \mathrm{d}}$ & $7.5^{\mathrm{c}}$ & $1.44^{\mathrm{a}}$ & $6.8^{\mathrm{c}, \mathrm{d}}$ & $147^{\mathrm{b}}$ & 3.80 & $4.9^{\mathrm{c}, \mathrm{d}}$ & 5.51 \\
\hline Average & $0.592^{\mathrm{a}}$ & 11.1 & $0.510^{\mathrm{a}}$ & $0.98^{\mathrm{c}}$ & $29^{\mathrm{c}}$ & $1.40^{\mathrm{a}}$ & $6.4^{\mathrm{c}}$ & $138^{\mathrm{b}}$ & 3.69 & $25^{\mathrm{c}}$ & 5.66 \\
Std. Dev. & 0.161 & 5.9 & 0.170 & 1.65 & 22 & 0.22 & 10.4 & 25 & 0.64 & 27 & 0.63 \\
RSD, \% & 27 & 53 & 33 & 168 & 76 & 16 & 161 & 18 & 17 & 109 & 11 \\
\hline
\end{tabular}

${ }^{\mathrm{a}}$ Valid blank correction (blank $>10 \%$ but $<30 \%$ of sample value).

${ }^{\mathrm{b}}$ Invalid blank correction (blank $>30 \%$ of sample value).

${ }^{\mathrm{c}}$ Blank-corrected below detection limits.

${ }^{\mathrm{d}} \mathrm{RD}$ for duplicate traps $>20 \%$.

These concentration values were compared to the uncontrolled values calculated from the coal composition to determine the capture of the metals in the bottom ash, multicyclone, and scrubber prior to the stack. These results are summarized in Table 23. For EPA M29, the capture was greater than $99 \%$ for $\mathrm{Be}, \mathrm{Cr}, \mathrm{Co}, \mathrm{Pb}$, and $\mathrm{Mn}$. Capture for $\mathrm{Sb}$ was greater than $95 \%$, capped only by the method detection limit. Capture for $\mathrm{As}, \mathrm{Cd}$, and $\mathrm{Ni}$ was greater than $94 \%$. The more volatile metals, $\mathrm{Hg}$ and $\mathrm{Se}$, showed $81 \%$ and $91 \%$ capture, respectively. It should be noted that baseline conditions for this unit include activated carbon injection for $\mathrm{Hg}$ control, which presumably had an effect on Se control as well.

Table 23. Trace Metals Capture at Plant 3 Using EPA M29 and ME-ST-M Data

\begin{tabular}{|c|c|c|c|c|c|c|c|c|c|c|c|}
\hline \multirow[b]{2}{*}{ Method } & \multicolumn{11}{|c|}{$\mu \mathrm{g} / \mathrm{dNm}^{3}$ at $3 \% \mathrm{O}_{2}$} \\
\hline & $\mathrm{Sb}$ & As & $\mathrm{Be}$ & $\mathrm{Cd}$ & $\mathrm{Cr}$ & Co & $\mathrm{Pb}$ & $\mathrm{Mn}$ & $\mathrm{Hg}$ & $\mathrm{Ni}$ & $\mathrm{Se}$ \\
\hline Uncontrolled & 49.6 & 674 & 54.4 & 8.7 & 739 & 240 & 465 & 11,625 & 20.1 & 312 & 89 \\
\hline EPA M29, & $<1$ & 8.57 & 0.342 & 0.492 & $4.3^{\mathrm{a}}$ & 0.878 & 2.73 & $73^{a}$ & 3.81 & $4.6^{\mathrm{a}}$ & 8.11 \\
\hline Capture, $\%$ & $>98$ & 98.7 & 99.4 & 94.3 & 99.4 & 99.6 & 99.4 & 99.4 & 81.0 & 98.5 & 90.9 \\
\hline ME-ST-M & $0.592^{\mathrm{b}}$ & 11.1 & $0.510^{\mathrm{b}}$ & $0.98^{\mathrm{c}}$ & $29^{c}$ & $1.40^{\mathrm{b}}$ & $6.4^{\mathrm{c}}$ & $138^{\mathrm{a}}$ & 3.69 & $25^{\mathrm{c}}$ & 5.66 \\
\hline Capture, \% & 98.8 & 98.4 & 99.1 & 88.7 & 96.1 & 99.4 & 98.6 & 98.8 & 81.6 & 92.0 & 93.6 \\
\hline
\end{tabular}


A summary of the metals results data for Plant 3 is shown in Figure 16 (it should be noted that graphical comparison between the two methods for each of the trace metals and a more detailed explanation of the results are provided in Appendix C). For both methods, the data for $\mathrm{As}, \mathrm{Be}, \mathrm{Cd}, \mathrm{Cr}, \mathrm{Pb}$, and $\mathrm{Mn}$ are shown to be above the MATS limits for the unit, and $\mathrm{Sb}$ and $\mathrm{Hg}$ are shown to be below the MATS limits. For $\mathrm{Co}, \mathrm{Ni}$, and $\mathrm{Se}$, the methods differ, with one reporting values above the limit and one below.

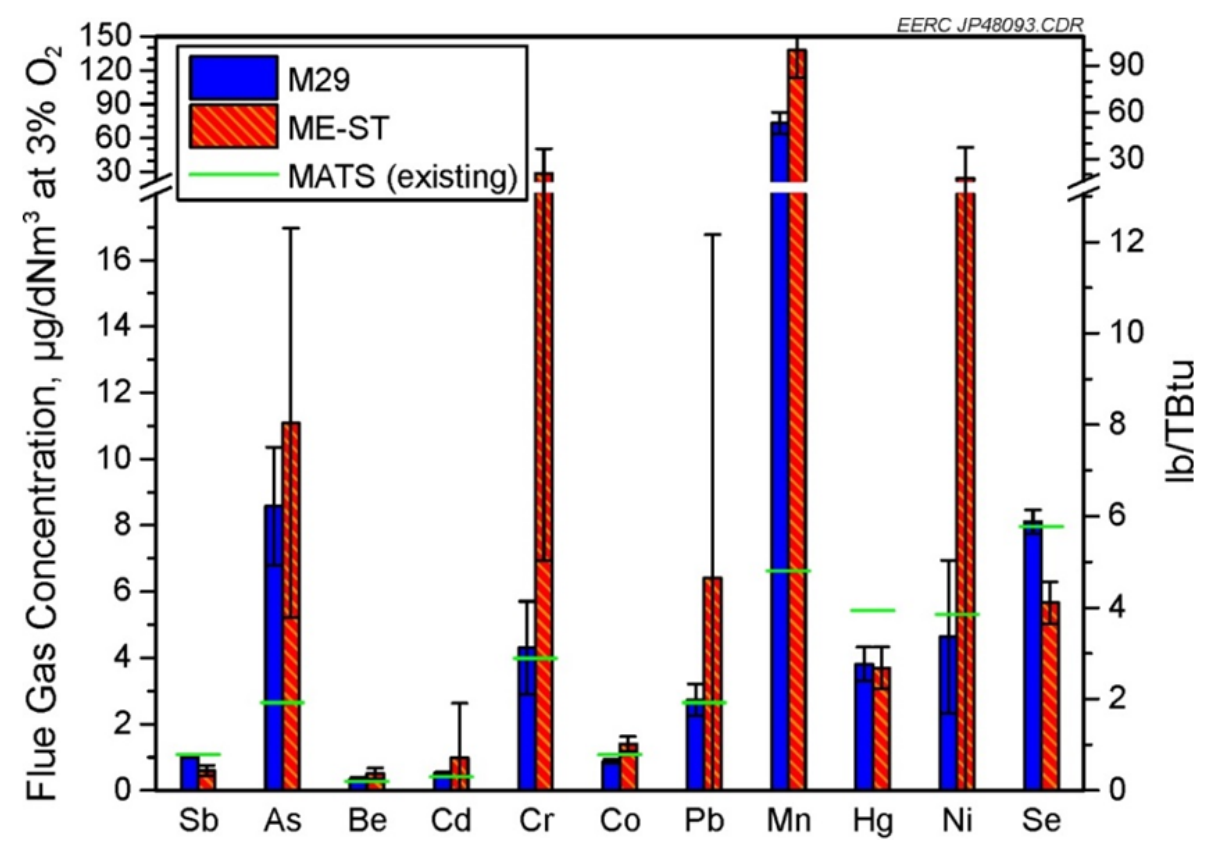

Figure 16. Comparison of sampling results for EPA M29 and the ME-ST-M method for Plant 3.

\section{Statistical Comparison of the ME-ST Method to Reference Methods}

Although the three data sets obtained in this project are too few for a complete EPA M301 validation study, procedures set out in M301 were used to statistically compare the ME-ST-H and ME-ST-M methods to the EPA reference methods EPA M26A and EPA M29, respectively (15). In addition, QA/QC criteria established by the reference methods and ME-ST methods, in some cases, gave invalid results. This was especially true for a number of the metals measured using EPA M29 and the ME-ST-M. Therefore, for some metals, fewer than the nine sets of paired method samples required by EPA M301 were used to complete the statistical analysis.

The project criteria established for evaluation of precision and bias were as follows:

- A valid statistical comparison between the two trace metal-sampling methods can only be made if both methods have results above the detection limit and the background (blank) concentrations are $\leq 30 \%$ of the measured value.

- Because trace metals concentrations are often at or near the detection limits of one or both of the sampling methods, the blank-corrected concentrations often fall below the 
detection limits. Only samples where both measurements were above detection limits were included in the statistical analysis.

- For the ME-ST-M method, the RD for the paired traps must be $\leq 20 \%$. As was previously discussed, the results for both methods taken simultaneously must be valid for the metal of interest to be used in the statistical analysis.

The M301 procedures compare the relative bias (Equation 301-7) and precision (Equation 301-10) of an alternative method to that of a reference method. The significance of any bias for the alternate method compared to the reference method for any individual trace metal or halogen is determined by comparing the calculated t-statistic for the number of valid samples analyzed (Equation 301-7) to the t-statistic tables at the 95\% confidence level and the appropriate degrees of freedom. If the bias is significant (calculated t-statistic $>$ the $t$-statistic from the tables) the actual bias must be calculated. If the calculated bias is $\leq 10 \%$, then it is insignificant, and the two methods are statistically the same. If the bias is $>10 \%$ but $\leq 30 \%$, the bias is significant, but a bias correction can be applied.

Method precision was calculated based on the variance between the methods for the valid samples. The estimated variance is calculated for the two sampling methods using Equation 30111 and then the F-value is calculated as defined in Equation 301-12. This value is then compared to the one-sided F-statistic at the $95 \%$ confidence level. If the calculated F is outside this critical range, the difference in precision is significant.

\section{HCl Results}

As stated previously, $\mathrm{HCl}$ was measured at each of the three sites using EPA Method 26A and ME-ST-H sorbent traps. The average results and statistical comparisons for each method are shown in Table 24 and Figure 17. The ME-ST-H method performed very well for $\mathrm{HCl}$ at Plants 1 and 2. However, the precision of the two methods was shown to be not acceptable for this set of data. The variance of the ME-ST-H paired trap value was calculated to be 0.0188 and, for EPA M26A, 0.0014, resulting in an F value of 13.5, which is greater than the one-sided $F$ value of 3.4381 for 8 degrees of freedom. However, although the variance was not acceptable based on EPA M301 criteria, the actual difference between the two methods is relatively small, but because the EPA M26A results were very tight for this data set, the ME-ST-H precision comparison failed the F test. One should note that the variability of EPA M26A is generally not this tight, and given that, the ME-ST-H method would have passed the $\mathrm{F}$ test. The $\mathrm{HCl}$ concentration in the flue gas ranged from 0.2 to $1.6 \mathrm{dppm}(\mathrm{v})$, challenging the methods. Figure 17 combines the data from the three test sites showing the range and comparing the ME-ST-H method to the reference method, EPA M26A. If the data matched perfectly, all of the data would line up in a straight $45^{\circ}(1: 1)$ line. Also shown on the graph are the $\pm 20 \%$ and $\pm 50 \%$ range lines, which are truncated below three significant figures and replaced with the detection limit value at the detection limit. The detection limit for EPA M26A, based on the project sampling results, is shown on the left side of the graph in gray. The results for EPA Method 26A from Power Plant 3 were $<0.04$ and, therefore, plotted at the detection limit. The MATS limits are also plotted for reference. 
Table 24. Average Concentrations and Statistical Analysis of HCl Results for EPA M26A and the ME-ST-H Method (all concentrations are in dppmv)

\begin{tabular}{lccc}
\hline $\mathrm{HCl}$ & Site 1 & Site 2 & Site 3 \\
\hline "Uncontrolled" Emissions ${ }^{\mathrm{a}}$ & 2.00 & 1.43 & 1.15 \\
M26A Average & 0.23 & 1.36 & $<0.04$ \\
ME-ST-H Average & 0.25 & 1.24 & 0.26 \\
$\%$ Bias & 23.0 & Eq $(<10 \%)$ & ND \\
F-Test & Pass & Fail & \\
\hline
\end{tabular}

${ }^{a}$ Calculated from the coal chloride concentrations.

${ }^{\mathrm{b}}$ Failed because Method 26A data was extremely tight for data set.

Equivalent (Eq) - Either on or both samples methods are below the detection limit or there is no significant bias.

ND - Not determined.

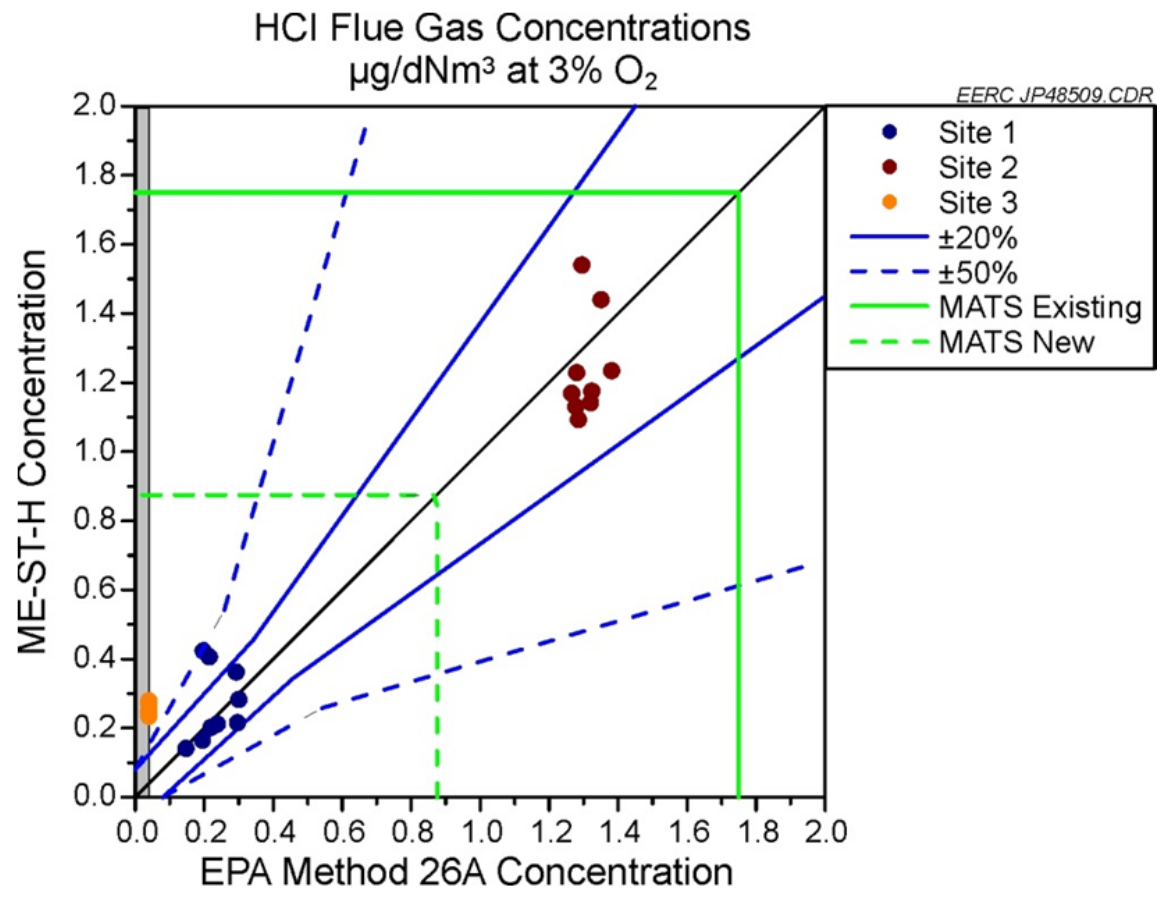

Figure 17. Average flue gas $\mathrm{HCl}$ results comparing EPA M26A with ME-ST-H

At Plant 3 (as shown in Figure 17), there appears to be a significant bias between the two methods for $\mathrm{HCl}$, with M26A measuring nondetect levels at a detection limit of $0.04 \mathrm{ppmv}$, while the ME-ST-H method measured detectable levels with an average concentration of $0.26 \mathrm{ppmv}$. Again, as was discussed previously, this is most likely a result of the saturated wet stack. 


\section{Trace Metals}

As stated previously, the QA/QC criteria established by EPA M29 and ME-ST-M method gave invalid results for a number of the metals. Therefore, for some metals, fewer than the nine sets of paired method samples required by EPA M301 were used to complete the statistical analysis. Table 25 presents the results of the statistical analysis of the metals data for the three test series.

Table 25. Statistical Comparison of the Average Trace Metal Results for EPA Method 29 and the ME-ST-M Method (all concentrations are $\mu \mathrm{g} / \mathrm{Nm}^{3}$ )

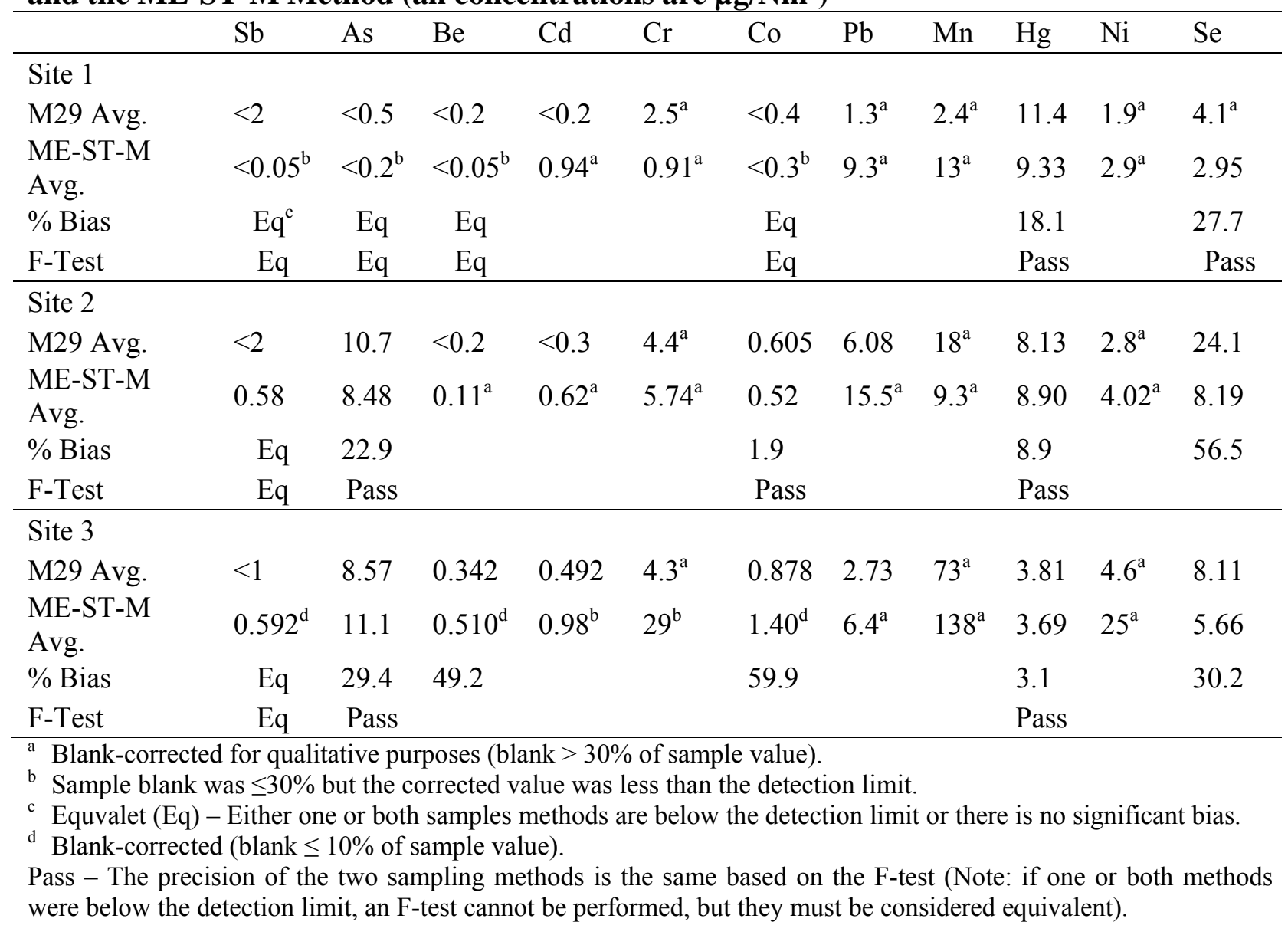

Information presented in Table 25 is as follows:

- Average concentrations for the M29 and ME-ST-M test runs at each plant. Footnotes to the values indicate whether the average value was corrected for field blank results, whether the blank correction was within the criteria allowed by the methods (blank $\leq 30 \%$ of sample), and whether blank correction resulted in an average below the method detection limit. If the blank corrected analysis is below the detection limit of one or both of the sampling methods, Table 25 shows this as a "less than" value and is footnoted as "b." If the field blank results were $>30 \%$ of the sample, a blank correction 
is not allowed, and a statistical analysis of the results cannot be made. However, for those samples where the measured concentrations were above the LOQ, a background correction was still made and the results reported for qualitative purposes (no statistical analysis was performed). These results are footnoted in Table 25 as "a."

- Relative bias (\%) calculated according to M301, Equation 301-7. The relative bias is an absolute value. It does not indicate whether the direction of bias is positive or negative for a particular method. If the two methods are shown to have no bias $(\leq 10 \%)$ based on the statistical outlined in EPA M301 then they are shown as equivalent (Eq) in Table 25. The calculated bias is reported in Table 25 if the bias was determined to be $>10 \%$.

- F-test result. The entries in this row indicate whether the precision of the ME-ST-M method is significantly different than the precision of EPA M29 for that element. If the concentrations were below the detection limit for one or both of the methods the Fcalculations cannot be completed. These values are shown in Table 25 as equivalent (Eq). If the F-statistical analysis can be completed then the determination is simply pass or fail as shown in Table 25.

A valid statistical comparison between the two trace metal-sampling methods for individual trace metals for valid samples can be made if both methods have results above the detection limit and the background (field blank) concentrations are $\leq 30 \%$ of the measured value. It should be noted that if the results for both methods are below detection limits, then they must be considered statistically equivalent. The data set for each of the three plants tested that met the above criteria is limited. However, for those metals where the measured concentrations are above the detection limit of the method but the blank correction is $>30 \%$, a qualitative comparison of the methods can still be made.

For Plant 1, the only trace metals for which a valid statistical comparison could be made were $\mathrm{Hg}$ and Se. The data for each method appear consistent, but the averages show a bias for both $\mathrm{Hg}$ and Se for the ME-ST-M method as compared to the reference method EPA M29. In general, the data for the ME-ST-M method compared to EPA M29 were somewhat lower for these two metals.

For $\mathrm{Hg}$, the relative bias was significant at the $95 \%$ confidence level. The relative bias of EPA M29 over ME-ST-M for Hg was calculated to be $18.1 \%$, which is outside the range of $10 \%$ to be insignificant but less than $30 \%$. As a result, a correction factor can be applied to make the ME-ST-M valid for $\mathrm{Hg}$. As shown in Table 25, the concentration of $\mathrm{Hg}$ was greater using EPA M29. In addition, the precision of the two methods for $\mathrm{Hg}$ was statistically compared (F-test) and was shown to be comparable (Pass). For Se, the t-statistic calculations resulted in a statistical bias of $27.7 \%$. Again, this is $\leq 30 \%$; therefore, a bias correction can be made.

For Plant 2, it was possible to complete a statistical analysis of the data (above detection limits and $<30 \%$ background correction) for $\mathrm{As}, \mathrm{Co}, \mathrm{Hg}$, and $\mathrm{Se}$, as shown in Table 25 . At Plant 2, there was no significant bias for $\mathrm{Co}$ and $\mathrm{Hg}$, and the results for both metals passed the Ftest for precision. For As and Se, there was a significant bias between the two methods. For As, a bias correction factor is allowed $(>10 \%$ but $\leq 30 \%)$ but not for Se $(56.5 \%)$. For both As and Se, the concentration was greater using EPA M29 compared to the ME-ST-M method. 
For Plant 3, there was no significant bias between the methods for $\mathrm{Hg}$. For As, the bias was significant, but a correction is allowed. Unlike at Plant 2, the measured As concentration was greater using the ME-ST-M method. For Be, $\mathrm{Co}$, and Se, the bias was $>30 \%$, and therefore, the two methods are not comparable, and a bias correction cannot be applied.

Comparative results, uncertainty ranges, and detection limits for each of the trace metals based on the two sampling methods comparison are shown in Figures 18 through 28, with plantby-plant discussion included in Appendix C.

A comparison of the methods for Be is shown in Figure 19. The data from the first two sites are comparable, as all of the EPA M29 data were less than the detection limits. The data from Power Plant 3 are near the detection limit and have a high degree of uncertainty at this level. The comparison of bias and precision was shown to be unacceptable because of this uncertainty. It can be seen from the graph that both methods are capable of obtaining data to meet the requirements for existing units $\left(0.27 \mu \mathrm{g} / \mathrm{dNm}^{3}\right)$, but both methods are near the detection limit and cannot provide 3 significant figures at this level (i.e., greater than 10 times the detection limit), therefore making determination of compliance difficult at best. The MATS limit for new units is $0.07 \mu \mathrm{g} / \mathrm{dNm}^{3}$, which is below the detection limit of Be for EPA M29. Although the detection limit is lower for the ME-ST-M method $\left(0.05 \mu \mathrm{g} / \mathrm{dNm}^{3}\right)$, the uncertainty at the detection limit is too large and, therefore, this uncertainty is too large to be able to reliably and repeatedly determine regulatory compliance for units required to meet the MATS limits for new units.

A comparison of the methods for Co is shown in Figure 21. The data from Power Plant 1 are comparable, as all of the EPA M29 data were less than the detection limits. The data from Power Plants 2 and 3 are near the detection limit and have a high degree of uncertainty at this level. The comparison of bias and precision was shown to be unacceptable for Site 3 because of this uncertainty. It can be seen from the graph that both methods are capable of obtaining data to meet the requirements for existing units $\left(1.1 \mu \mathrm{g} / \mathrm{dNm}^{3}\right)$, but both methods are near the detection limit and cannot provide three significant figures at this level (i.e., greater than 10 times the detection limit), therefore making determination of compliance difficult at best. The MATS limit for new units is $0.27 \mu \mathrm{g} / \mathrm{dNm}^{3}$, which is below the detection limit of Co for both methods, making determination of compliance impossible for new units.

A comparison of the methods for $\mathrm{Sb}$ is shown in Figure 27. The data from EPA M29 were all below the detection limit $\left(2 \mu \mathrm{g} / \mathrm{dNm}^{3}\right)$, which is above the equivalent MATS limits $\left(1.1 \mu \mathrm{g} / \mathrm{dNm}^{3}\right)$. It is, therefore, impossible to determine compliance based on EPA M29 data, unless extending sampling duration. The detection limit for the ME-ST-M method $\left(0.05 \mu \mathrm{g} / \mathrm{dNm}^{3}\right)$ is lower and can provide 3 significant figures at this level (i.e., greater than 10 times the detection limit). For these sites, after improvement in background levels of $\mathrm{Sb}$ for the ME-ST-M method, the QA/QC criteria for the method were met and the data showed that the units were in compliance with the MATS limits for Sb. The limitations of EPA M29 make the validation of the ME-ST-M method for Sb difficult, so an alternative validation method such as spiking will need to be used to validate the method or evaluation of M29 extended sampling durations. 


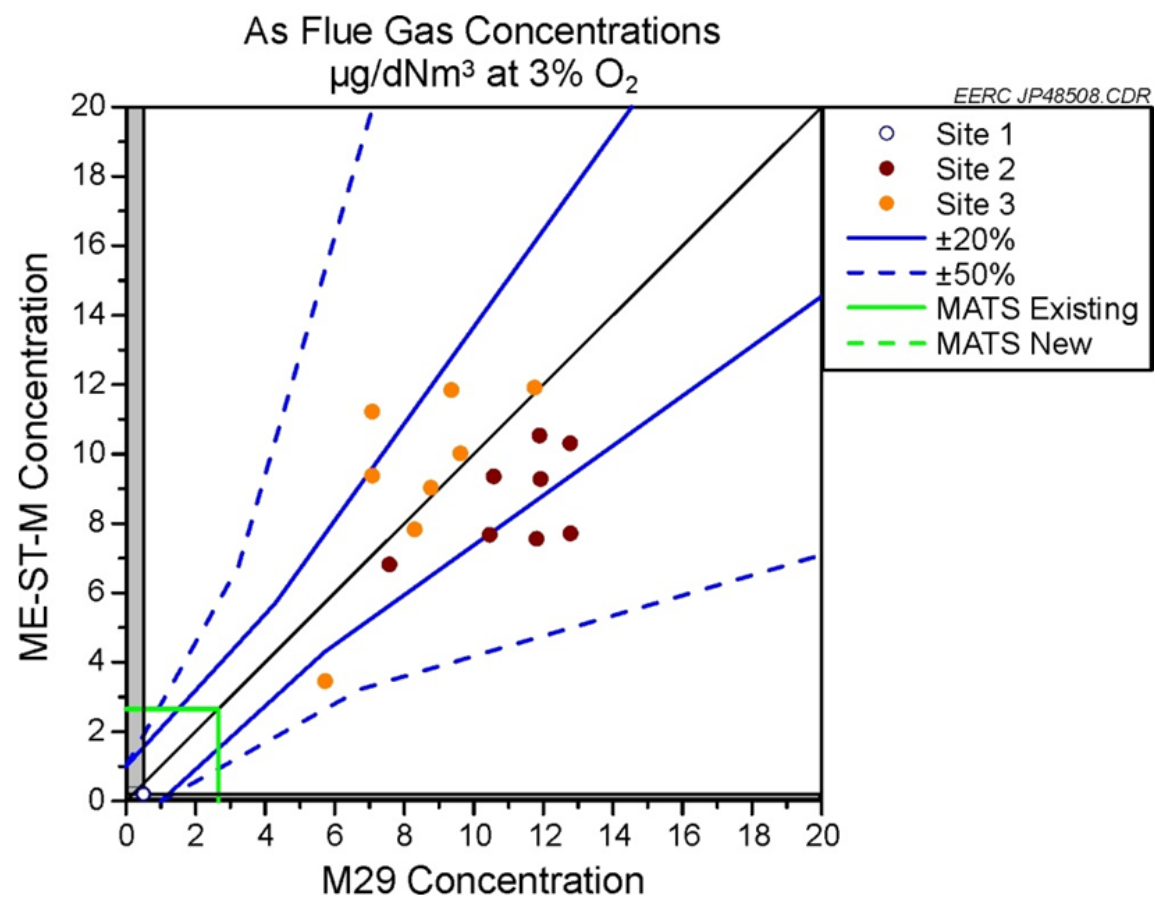

Figure 18. Comparison of ME-ST-M and EPA M29 data for As.

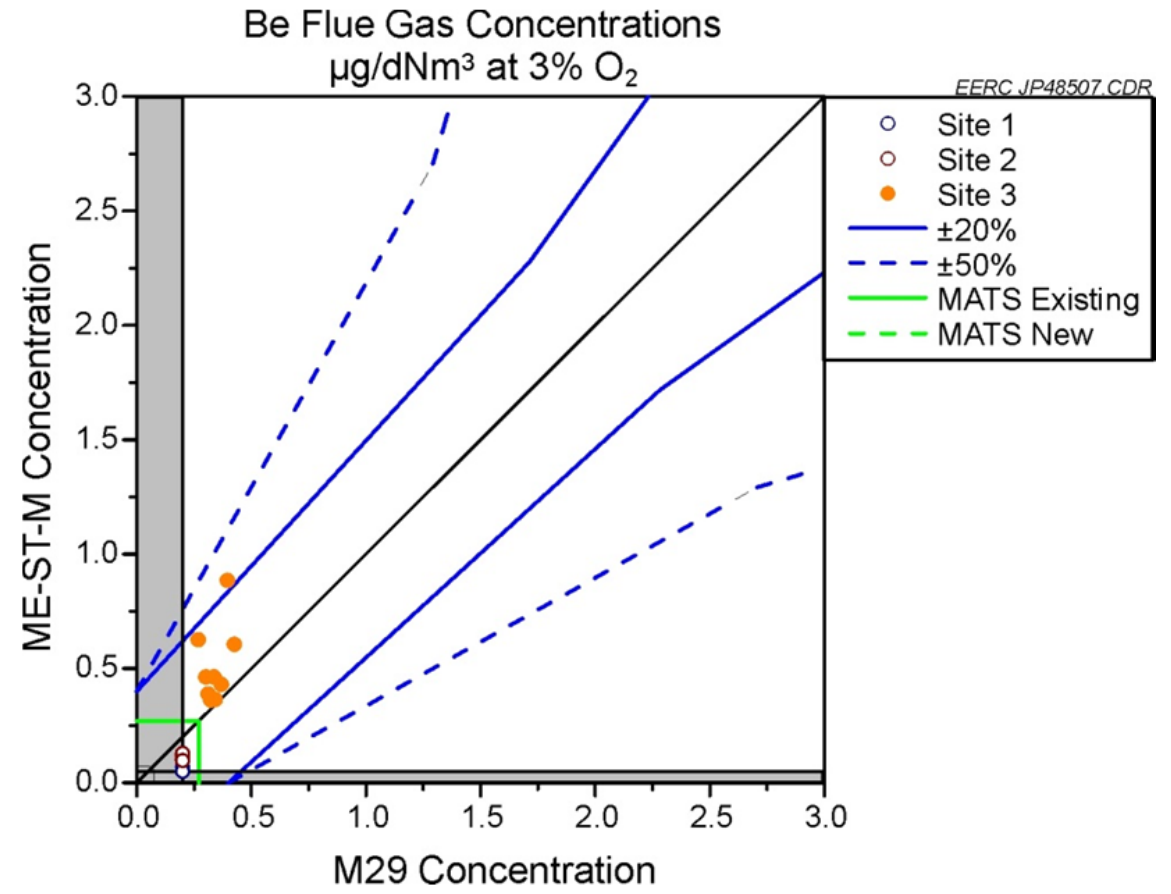

Figure 19. Comparison of ME-ST-M and EPA M29 data for Be. 


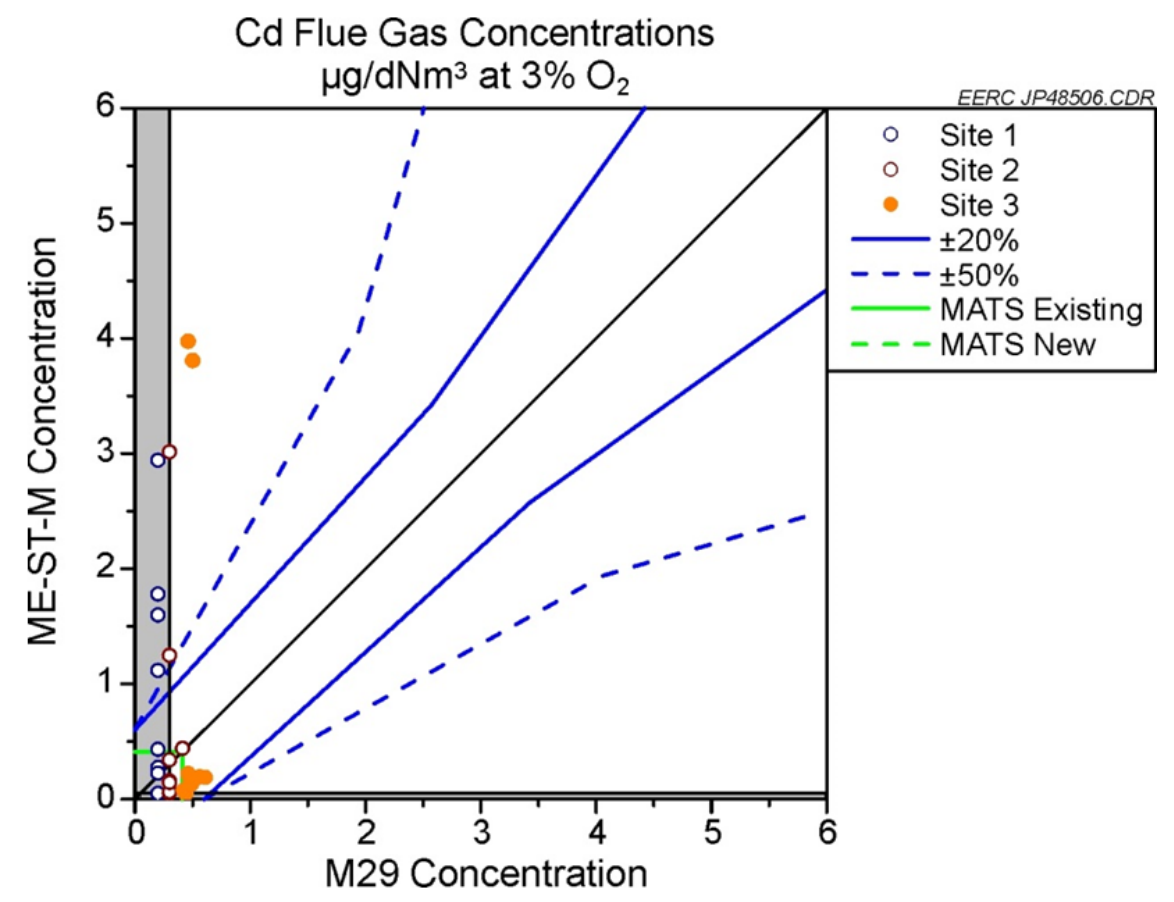

Figure 20. Comparison of ME-ST-M and EPA M29 data for Cd.

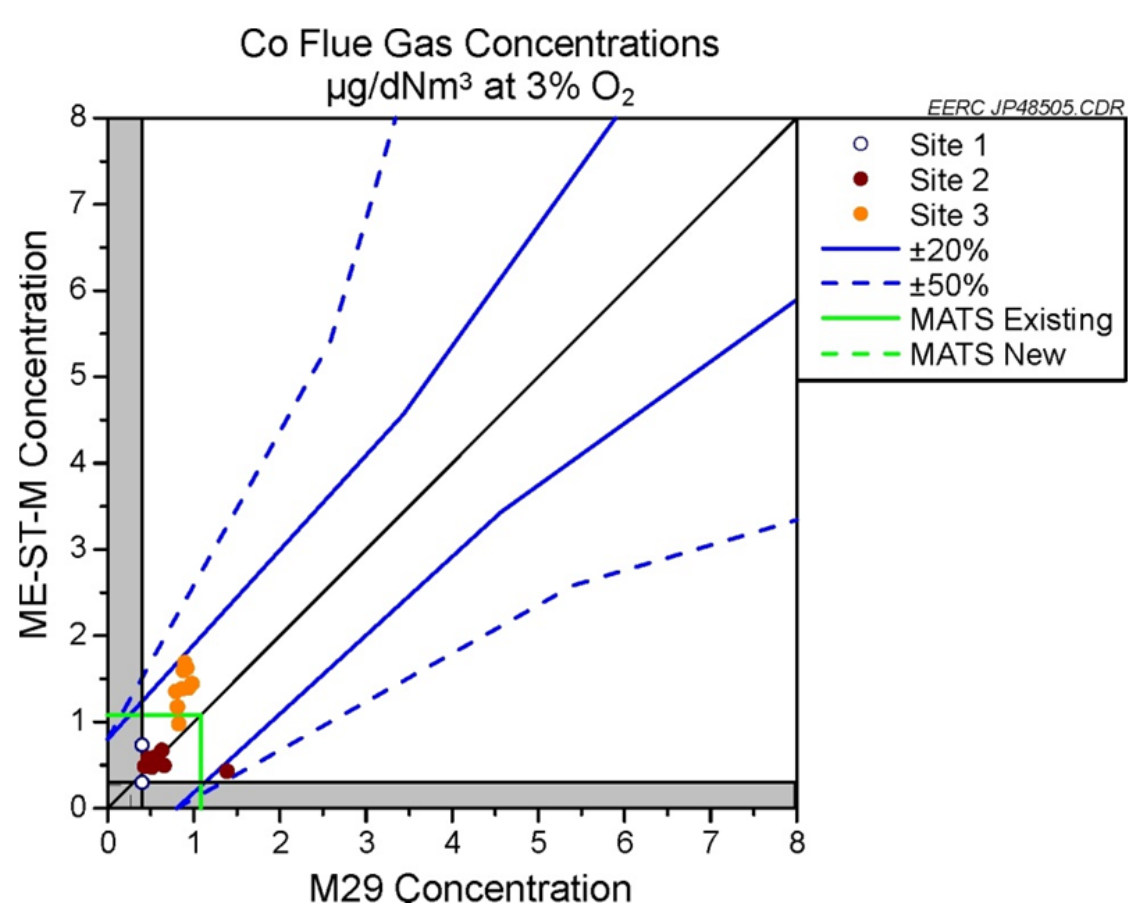

Figure 21. Comparison of ME-ST-M and EPA M29 data for Co. 


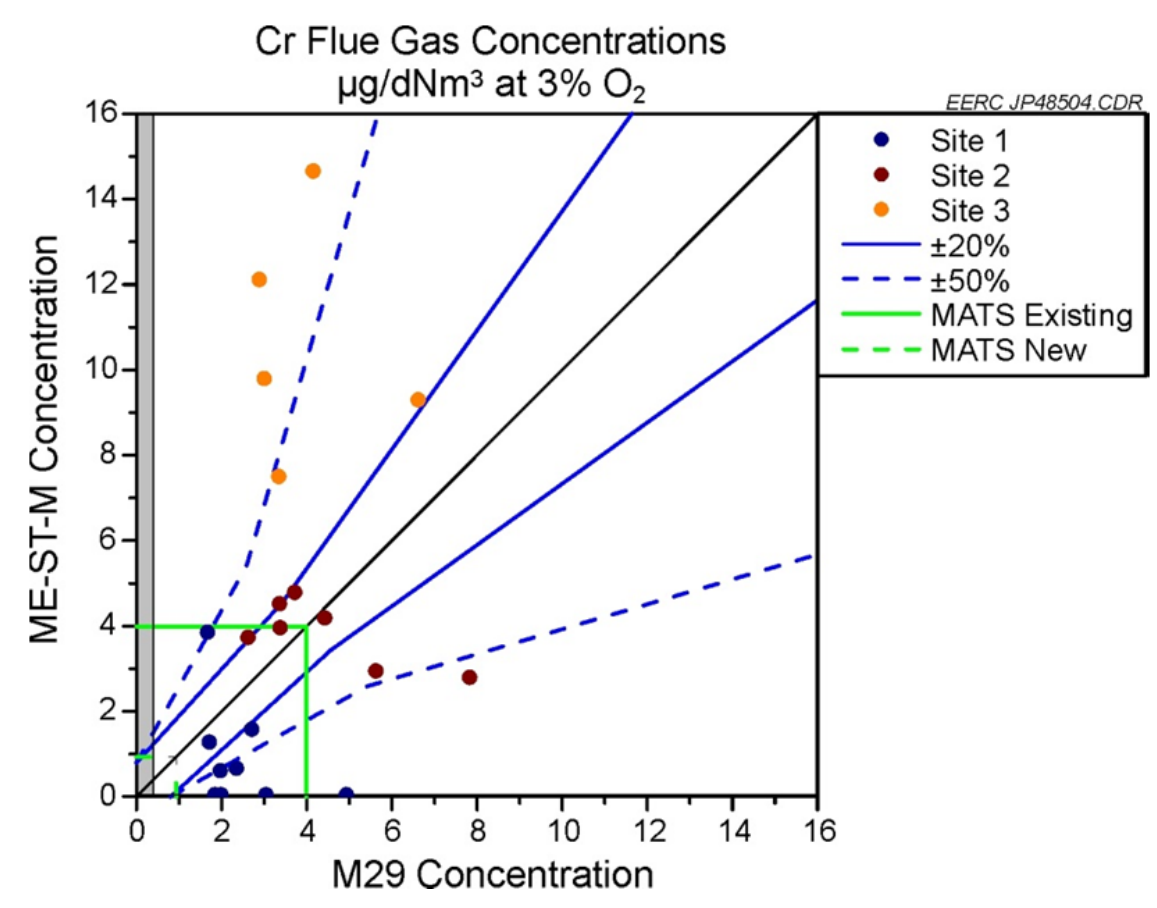

Figure 22. Comparison of ME-ST-M and EPA M29 data for Cr.

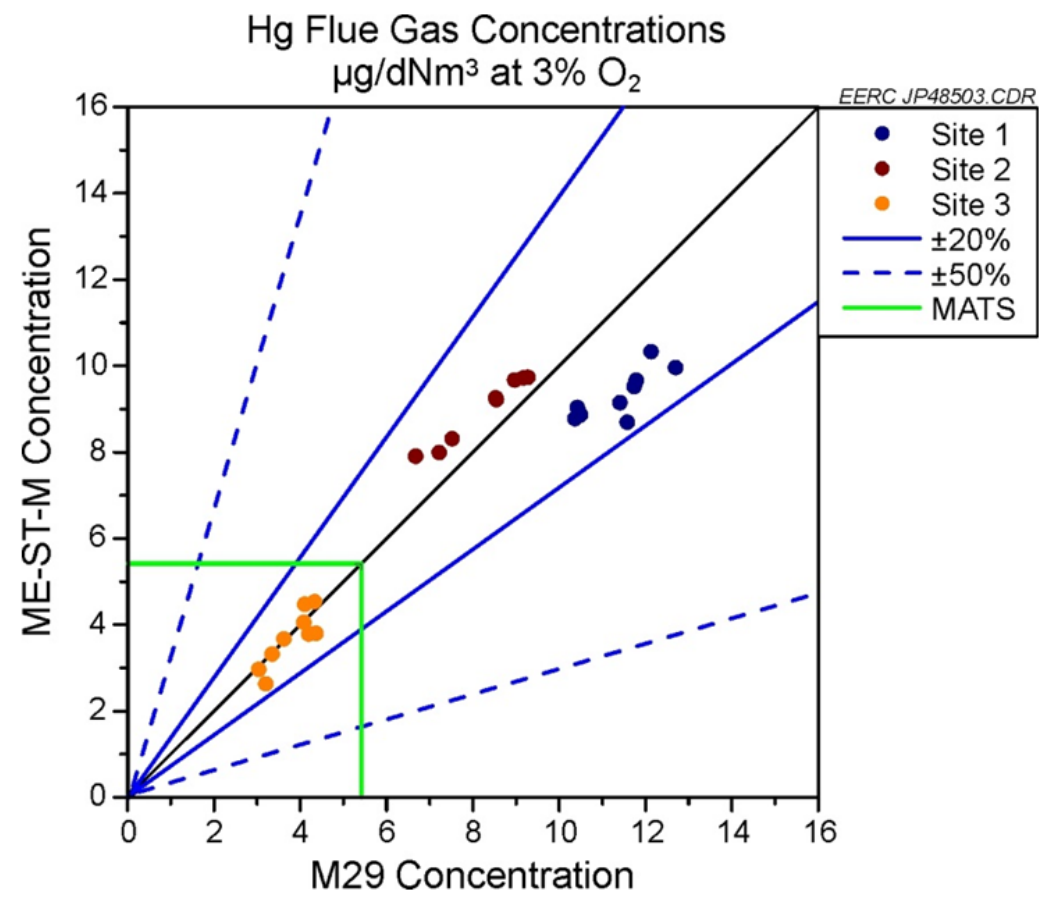

Figure 23. Comparison of ME-ST-M and EPA M29 data for Hg. 


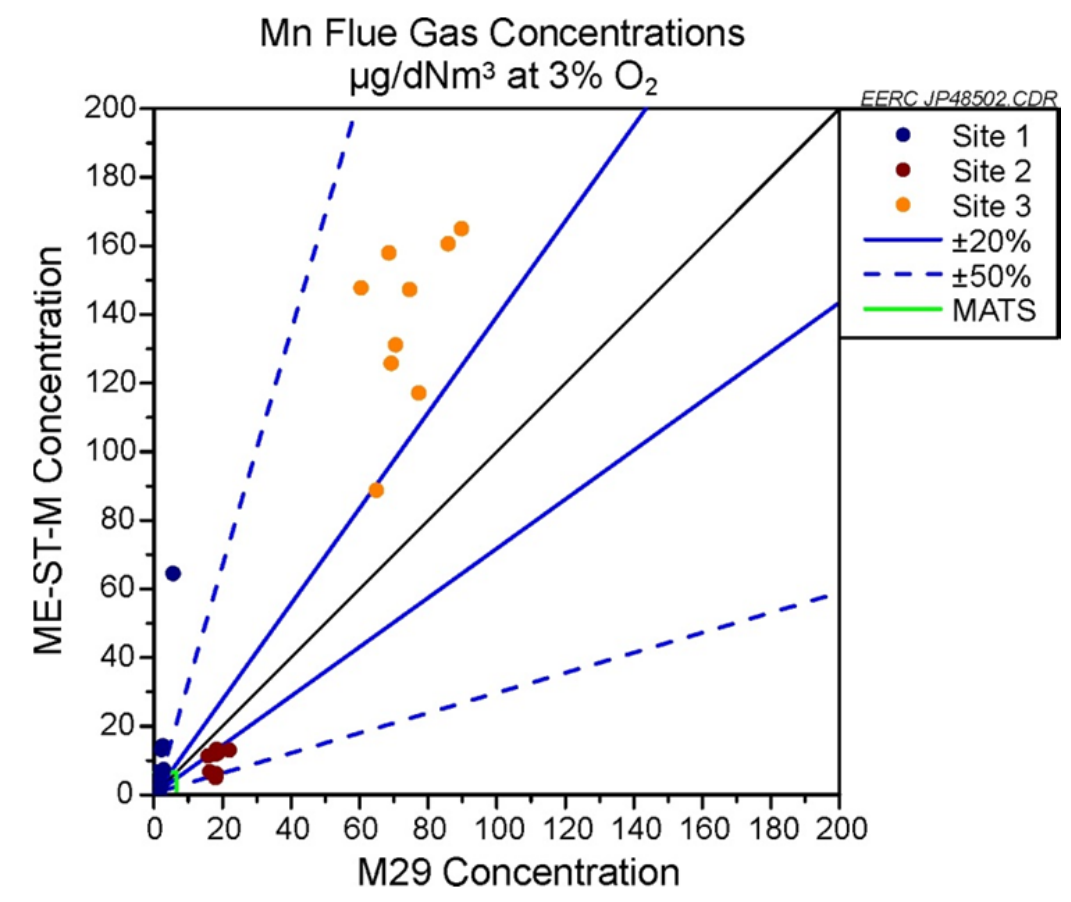

Figure 24. Comparison of ME-ST-M and EPA M29 data for Mn.

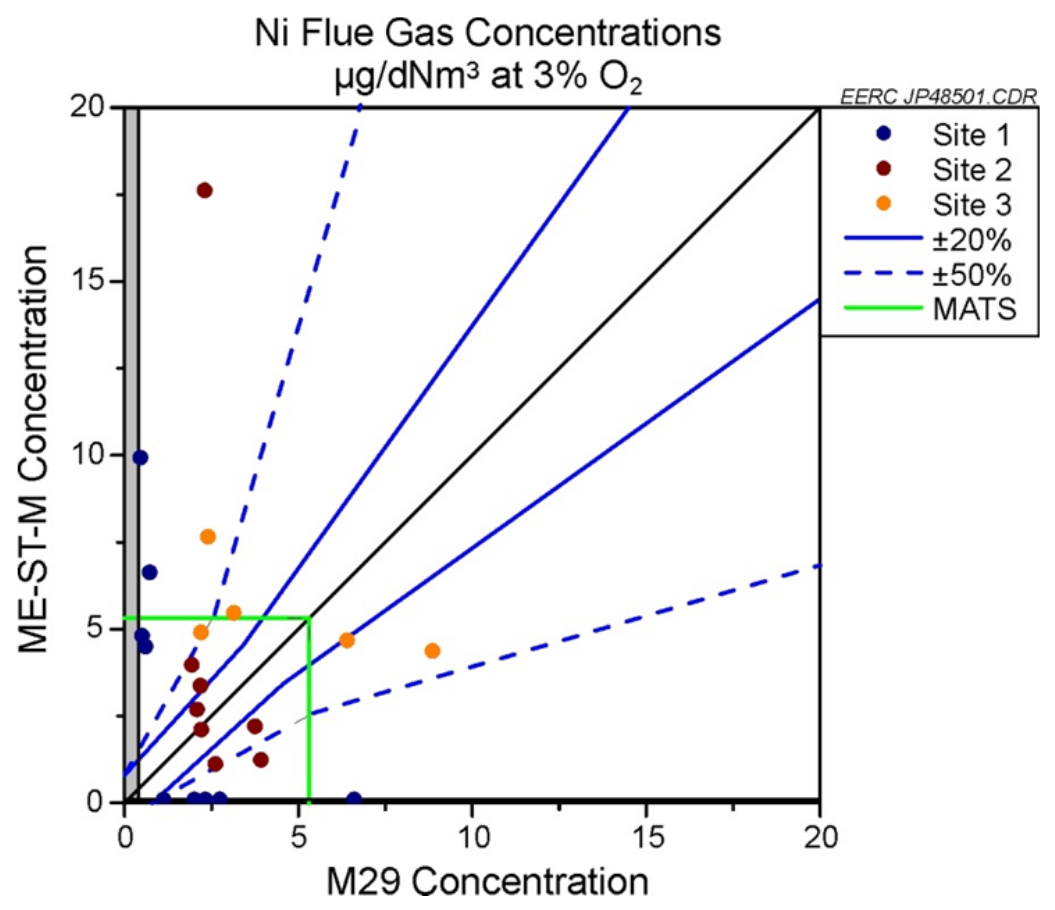

Figure 25. Comparison of ME-ST-M and EPA M29 data for Ni. 


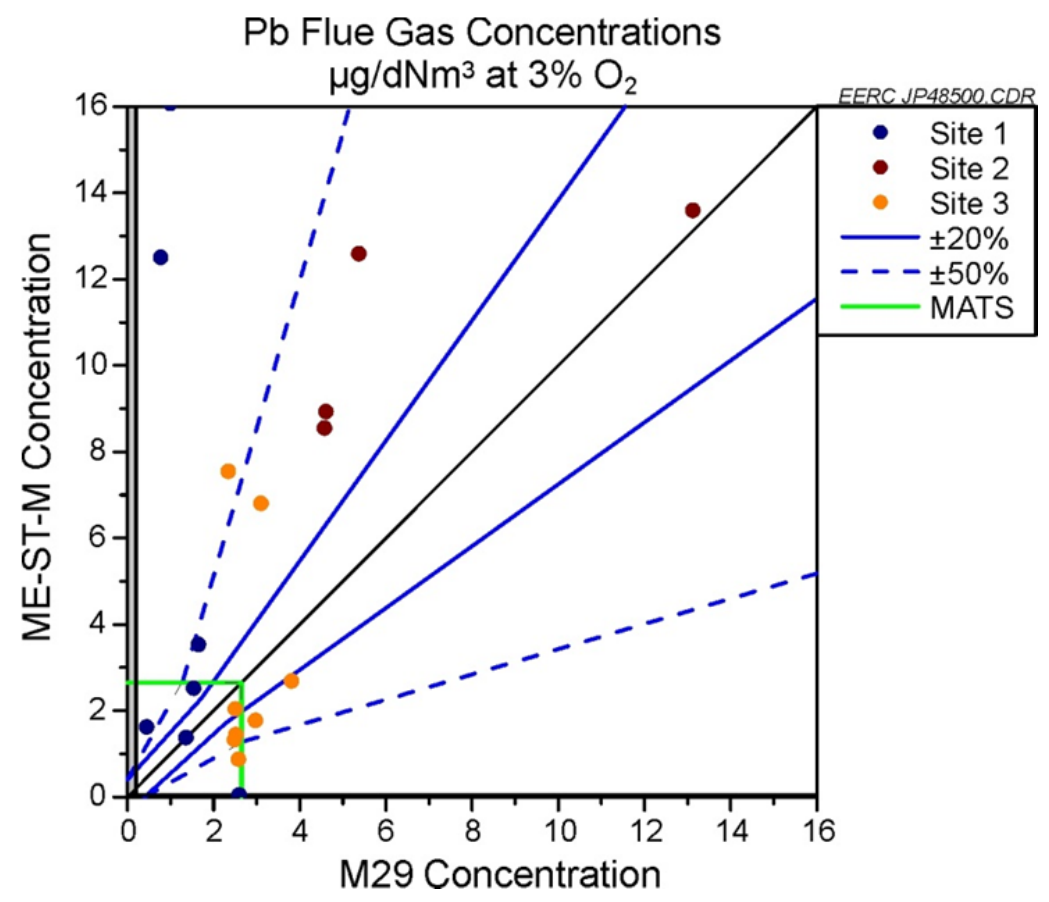

Figure 26. Comparison of ME-ST-M and EPA M29 data for Pb.

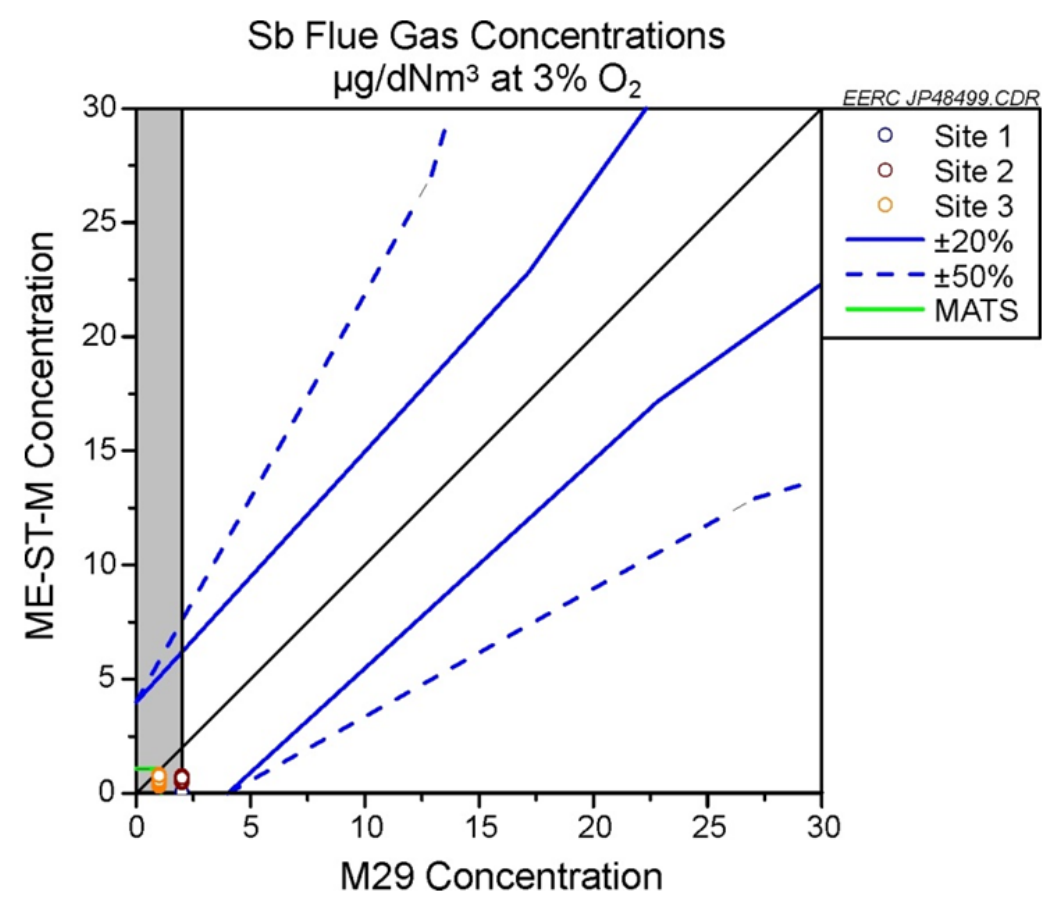

Figure 27. Comparison of ME-ST-M and EPA M29 data for Sb. 


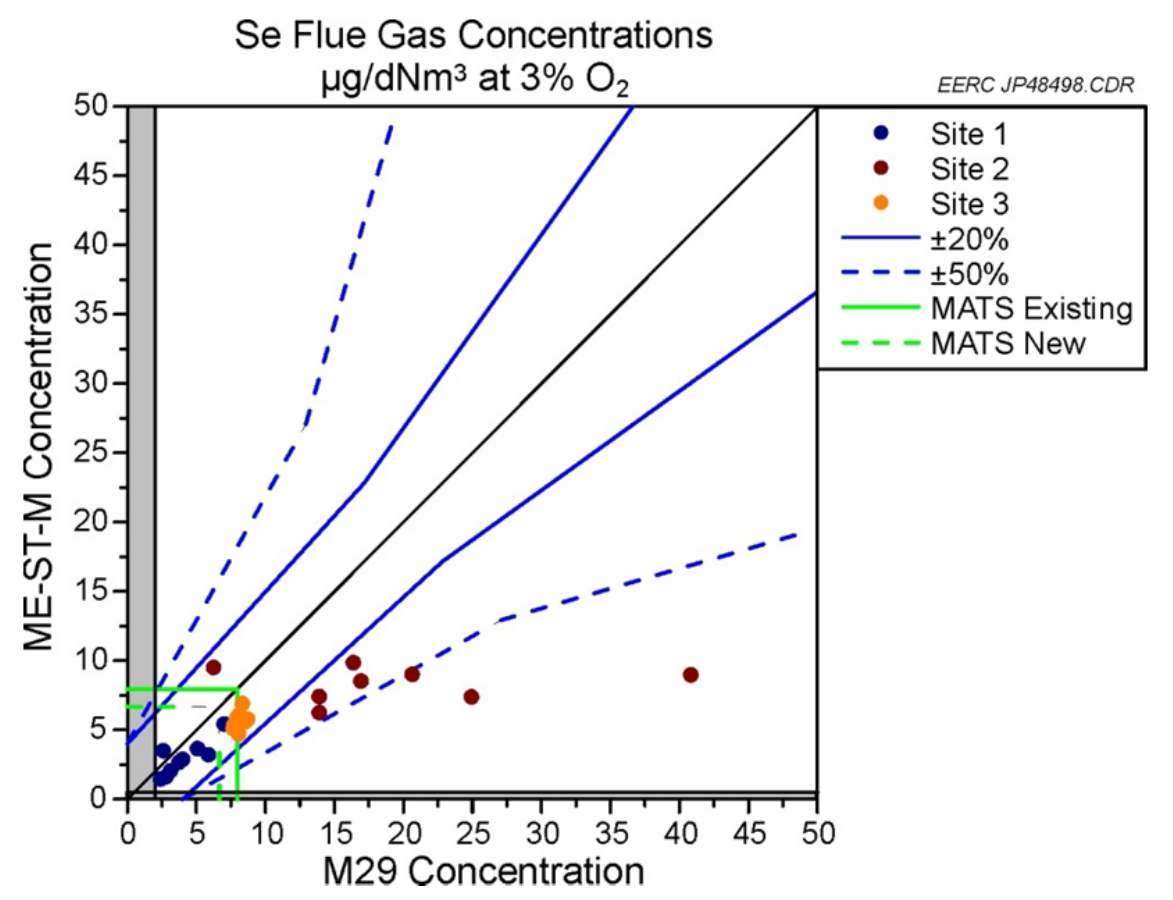

Figure 28. Comparison of ME-ST-M and EPA M29 data for Se.

A comparison of the methods for Se is shown in Figure 28. It can be seen from the graph that both methods are capable of obtaining data to meet the requirements for existing and new units $\left(8 \mu \mathrm{g} / \mathrm{dNm}^{3}\right.$ and $\left.7 \mu \mathrm{g} / \mathrm{dNm}^{3}\right)$, but EPA M29 is near the detection limit and cannot provide 3 significant figures at this level (i.e., greater than 10 times the detection limit), therefore making determination of compliance difficult utilizing EPA M29. The detection limit for the ME-ST-M method is lower and can provide 3 significant figures at the MATS limit. For these sites, after improvement in background levels of Se for the ME-ST-M method, the QA/QC criteria for the method were met and the data could be used to determine compliance with the MATS limits for Se. The range and variability of the EPA M29 data for Power Plant 2 indicate that there is (was) a problem, but under the limited scope of this project, a resolution could not be determined.

A comparison of the methods for $\mathrm{Hg}$ is shown in Figure 23. It can be seen from the graph that both methods are capable of obtaining data to meet the requirements for existing and new units $\left(5.42 \mu \mathrm{g} / \mathrm{dNm}^{3}\right)$. In fact, the detection limits for $\mathrm{Hg}$ allow for 3 significant figures at the most stringent of the MATS limits for $\mathrm{Hg}$, that being for new units burning subbituminous or bituminous coal $\left(0.45 \mu \mathrm{g} / \mathrm{dNm}^{3}\right)$. All QA/QC requirements are easily met with the ME-ST-M method, and the comparative method for validation under EPA M301 could be used to validate the method for compliance use.

In summary, the results showed that the ME-ST-M concentrations measured for $\mathrm{Hg}$, $\mathrm{Se}$, $\mathrm{Sb}, \mathrm{As}, \mathrm{Cd}$, and Co that were above the MATS limit showed good agreement between EPA M29 and the ME-ST-M method, generally within $20 \%$. Based on data from these three field tests, additional research is still needed for the ME-ST-M method to explore possible longer sampling durations and/or selection of lower-background materials containing near-zero $\mathrm{Pb}, \mathrm{Ni}, \mathrm{Cr}$, and 
Mn before the ME-ST-M can be considered as a potential alternative method to M29. For these same metals, field blanks can be relatively high (compared to MATS) for M29 as well. Consequently, lowering background concentrations and/or extending sampling durations for M29 should also be explored.

\section{Cost Analysis}

The primary advantages of the ME-ST methods over their respective wet-chemistry reference methods are that they can be easily deployed in the field without the use of strong acids, bases, or solvents. As a result, it is expected that the ME-ST methods will be safer and more flexible than EPA M29 or EPA M26/26A, as the sorbent traps can easily be shipped for analysis since multiple sample bottles containing hazardous solvents are not required. The MEST methods are also expected to be substantially less time-consuming and costly than EPA M29 or EPA M26A, based on a cost estimate shown in Table 26. Assumptions that were made for Table 26 are as follows (costs are on a per-sample basis):

- $\$ 25 / \mathrm{hr}$ for field samplers.

- $\$ 30 / \mathrm{hr}$ for a chemist.

- $\$ 10 /$ metal or halogen analyzed.

- Samples are shipped to an off-site laboratory overnight.

- EPA M29 and M26A samples require shipping as hazardous materials.

- $10 \%$ replacement cost for EPA M29 and M26A glassware per sample.

Other potential costs that were not quantified in Table 26 are as follows:

- Space for sample storage

- Space for equipment storage

- Equipment depreciation

- Power requirements

The cost of sample storage is not included, but would be higher for the EPA reference methods because of the substantial amount of glassware needed and the resulting potential for glassware breakage.

\section{QUALITY ASSURANCE/QUALITY CONTROL}

The primary documents guiding the $\mathrm{QA} / \mathrm{QC}$ for this project were the procedures outlined in EPA M29 and M26A and for the ME-ST methods, EPA M30B (Determination of Mercury from Coal-Fired Combustion Sources Using Carbon Sorbent Traps). For the two wet-chemistry methods, the primary QA/QC focus is on field and method blanks and calibration procedures for the instrumentation (ICP-MS and IC). For ME-ST methods, the QA/QC focus is on the use of duplicate traps, field blanks, breakthrough requirements, and instrument calibration procedures (CVAAS for $\mathrm{Hg}$ ). 
Table 26. Cost Analysis Comparing the EPA Reference Methods to the ME-ST Methods

\begin{tabular}{|c|c|c|c|c|c|c|c|c|}
\hline & \multicolumn{2}{|c|}{ EPA M29 } & \multicolumn{2}{|c|}{ ME-ST-M } & \multicolumn{2}{|c|}{ EPA M26A } & \multicolumn{2}{|c|}{ ME-ST-H } \\
\hline Labor & hr & $\$$ & $\mathrm{hr}$ & $\$$ & $\mathrm{hr}$ & $\$$ & $\mathrm{hr}$ & $\$$ \\
\hline Calibrations & 1 & 25 & 1 & 25 & 1 & 25 & 1 & 25 \\
\hline $\begin{array}{l}\text { Packing Equipment for } \\
\text { Transport }\end{array}$ & 1.5 & 37.5 & 0.2 & 5 & 1 & 25 & 0.2 & 5 \\
\hline Labeling & 1 & 25 & 0 & 0 & 0.7 & 17.5 & 0 & 0 \\
\hline $\begin{array}{l}\text { Setup (assembling and } \\
\text { weighing) }\end{array}$ & 1 & 25 & 0.2 & 5 & 0.8 & 20 & 0.2 & 5 \\
\hline $\begin{array}{l}\text { Transporting Samples to } \\
\text { Location }\end{array}$ & 0.5 & 12.5 & 0.1 & 2.5 & 0.4 & 10 & 0.1 & 2.5 \\
\hline Leak Check & 0.4 & 10 & 0.1 & 2.5 & 0.4 & 10 & 0.1 & 2.5 \\
\hline Sampling & 4 & 100 & 4 & 100 & 2 & 50 & 2 & 50 \\
\hline Leak Check & 0.6 & 15 & 0.1 & 2.5 & 0.4 & 10 & 0.1 & 2.5 \\
\hline Teardown & 1 & 25 & 0.2 & 5 & 0.8 & 20 & 0.2 & 5 \\
\hline Packing Samples & 0.5 & 12.5 & 0.1 & 2.5 & 0.5 & 12.5 & 0.1 & 2.5 \\
\hline $\begin{array}{l}\text { Sample Preparation for } \\
\text { Analysis }\end{array}$ & 1 & 30 & 0.4 & 10 & 0.8 & 24 & 0.2 & 5 \\
\hline \multirow[t]{2}{*}{ Glassware Cleaning } & 1 & 30 & 0 & 0 & 0.7 & 21 & 0 & 0 \\
\hline & 13.5 & 348 & 6 & 160 & 9.5 & 245 & 4 & 105 \\
\hline & \multicolumn{6}{|c|}{$\begin{array}{l}\text { Overhead and Fringe } \\
\text { Benefits }\end{array}$} & & 294 \\
\hline & & 1320 & & 610 & & 930 & & 400 \\
\hline \multicolumn{9}{|l|}{ Supplies } \\
\hline Chemicals & & 105 & & 0 & & 30 & & 0 \\
\hline Traps & & 0 & & 80 & & 0 & & 35 \\
\hline Glassware & & 110 & & 0 & & 75 & & 0 \\
\hline Misc. & & 50 & & 15 & & 50 & & 10 \\
\hline Packing for Shipment to & & 60 & & 5 & & 60 & $\begin{array}{l}\text { Packing lor snipment to } \\
\text { Laboratory }\end{array}$ & 5 \\
\hline & & 325 & & 100 & & 215 & & 50 \\
\hline \multicolumn{9}{|l|}{ Sample Analysis } \\
\hline $\mathrm{ICP}-\mathrm{MS}$ & & 300 & & 400 & & 0 & & 0 \\
\hline CVAAS & & 30 & & 40 & & 0 & & 0 \\
\hline \multirow[t]{2}{*}{ IC } & & 0 & & 0 & & 20 & & 40 \\
\hline & & 330 & & 440 & & 20 & & 40 \\
\hline \multicolumn{9}{|l|}{ Other Costs } \\
\hline $\begin{array}{l}\text { Sample Shipping } \\
\text { (overnight) }\end{array}$ & & 300 & & 20 & & 275 & & 20 \\
\hline Sample Disposal & & 10 & & 0 & & 5 & & 0 \\
\hline Communications & & 10 & & 5 & & 10 & & 5 \\
\hline \multirow[t]{2}{*}{ Printing } & & 10 & & 5 & & 10 & & 5 \\
\hline & & 330 & & 30 & & 300 & & 30 \\
\hline Contingency $(10 \%)$ & & 230 & & 70 & & 145 & & 50 \\
\hline Total Cost & & 2535 & & $\$ 1250$ & & $\$ 1610$ & & $\$ 570$ \\
\hline
\end{tabular}


The blanks that were completed as part of this study are an integral part of the project and are discussed in detail in the Results and Discussion section. The sources of the background for the two methods are different. For the ME-ST-M method, the majority of the background comes from the sorbent material. For EPA M29, the source of the background comes from the reagents and glassware. Early in the project, it became clear that more effort was needed to obtain sorbent material for the ME-ST-M method and higher-grade reagent for M29 that contained lower concentrations for a number of the trace metals (i.e., $\mathrm{Pb}, \mathrm{Mn}, \mathrm{Cr}$, and $\mathrm{Ni}$ ).

$\mathrm{Cr}, \mathrm{Mn}$, and Ni failed the QA/QC criteria for both EPA M29 and the ME-ST-M method, and a more serious effort to determine the feasible limits of the methods and/or improvement of the methods needs to be completed before accurate determination of regulatory compliance is feasible. Similarly, $\mathrm{Cd}$ and $\mathrm{Pb}$ were present in field blanks, and great care is required to obtain valid data. The ME-ST-M detection limits for these elements are sufficiently low to meet the regulatory requirements, but outside of a clean laboratory, the background present in field blanks has been shown to be significant, making it very difficult, if not impossible, to obtain valid data for flue gas concentrations that are near MATS limits.

The duplicate data for the pair traps for both the ME-ST-M and ME-ST-H methods are shown in Tables 27-32. For the ME-ST-H method, Tables 28-30, most of the duplicate traps had a RD of $<20 \%$, with many $<10 \%$. For the ME-ST-M method, Tables 30-32, the results for mercury were very good, with somewhat more variability for the other trace metals. For many of the duplicate traps, the RD was $<20 \%$, but inconsistencies varied throughout all of the samples set, with several traps having a $\mathrm{RD}$ of $>20 \%$.

Table 27. Power Plant 1 ME-ST-H Duplicate Sample Trap Results, dppmv at $\mathbf{3} \% \mathbf{O}_{\mathbf{2}}$

\begin{tabular}{lccccccccccc}
\hline & T1 & T2 & T3 & T4 & T5 & T6 & T7 & T8 & T9 & Avg. & RSD, \% \\
\hline Trap A & 0.393 & 0.291 & 0.179 & 0.161 & 0.125 & 0.146 & 0.208 & 0.239 & 0.391 & & \\
Trap B & 0.331 & 0.274 & 0.252 & 0.169 & 0.158 & 0.701 & 0.215 & 0.165 & 0.421 & & \\
RD, \% & 8.5 & 3.0 & 17.1 & 2.3 & 11.7 & $65.5^{*}$ & 1.5 & 18.1 & 3.7 & & \\
\hline Combined & 0.362 & 0.283 & 0.216 & 0.165 & 0.141 & - & 0.212 & 0.202 & 0.406 & 0.248 & 38 \\
\hline
\end{tabular}

Table 28. Power Plant 2 ME-ST-H Duplicate Sample Trap Results, dppmv at $3 \% \mathbf{O}_{2}$

\begin{tabular}{lllllllllllll}
\hline & T2 & T3 & T4 & T5 & T6 & T7 & T8 & T9 & T10 & T11 & Avg. & RSD, \% \\
\hline Trap A & 1.39 & 1.35 & 1.32 & 1.06 & 1.66 & 1.36 & 1.21 & 1.14 & 1.09 & 1.13 & & \\
Trap B & 1.08 & 1.11 & 0.87 & 1.27 & 1.42 & 1.52 & 1.14 & 1.12 & 1.20 & 1.01 & & \\
RD, \% & 12.7 & 9.7 & $20.7^{*}$ & 8.9 & 7.6 & 5.8 & 3.2 & 0.5 & 5.0 & 5.6 & & \\
\hline Combined & 1.23 & 1.23 & - & 1.17 & 1.54 & 1.44 & 1.18 & 1.13 & 1.14 & 1.07 & 1.24 & 12 \\
\hline
\end{tabular}

*Shaded values are those $>20 \%$. 
Table 29. Power Plant 3 ME-ST-H Duplicate Sample Trap Results, dppmv at $3 \% \mathbf{O}_{2}$

\begin{tabular}{lccccccccccc}
\hline & T1 & T2 & T3 & T4 & T5 & T6 & T7 & T8 & T11 & Avg. & RSD, \% \\
\hline Trap A & 0.30 & 0.27 & 0.34 & 0.24 & 0.26 & 0.21 & 0.25 & 0.25 & 0.26 & & \\
Trap B & 0.20 & 0.22 & 0.13 & 0.32 & 0.29 & 0.32 & 0.22 & 0.29 & 0.30 & & \\
RD, \% & 19.2 & 10.6 & $43.5 *$ & 13.1 & 5.0 & 20.5 & 4.8 & 7.9 & 7.2 & & \\
\hline Combined & 0.25 & 0.24 & 0.23 & 0.28 & 0.27 & 0.27 & 0.24 & 0.27 & 0.28 & 0.26 & 6.7 \\
\hline
\end{tabular}

Table 30. Power Plant 1 ME-ST-M Duplicate Sample Trap Results, $\mu \mathrm{g} / \mathrm{dNm}^{3}$

\begin{tabular}{|c|c|c|c|c|c|c|c|c|c|c|c|c|}
\hline \multirow[b]{2}{*}{ Sample } & \multirow[b]{2}{*}{ Trap } & \multicolumn{11}{|c|}{ Metals } \\
\hline & & $\mathrm{Sb}$ & As & $\mathrm{Be}$ & $\mathrm{Cd}$ & $\mathrm{Cr}$ & $\mathrm{Co}$ & $\mathrm{Pb}$ & $\mathrm{Mn}$ & $\mathrm{Hg}$ & $\mathrm{Ni}$ & $\mathrm{Se}$ \\
\hline TM-1 & A & $<0.05$ & $<0.3$ & $<0.05$ & $<0.05$ & 2.5 & 0.96 & $<0.05$ & 61 & 9.15 & $<0.1$ & 2.21 \\
\hline TM-1 & B & $<0.05$ & $<0.3$ & $<0.05$ & $<0.05$ & $<0.05$ & 0.51 & $<0.05$ & 69 & 9.14 & $<0.1$ & 1.91 \\
\hline $\mathrm{RD}, \%$ & & - & - & - & - & - & $30.5 *$ & & 6.2 & 0.0 & & 7.2 \\
\hline TM-2 & A & $<0.05$ & $<0.3$ & $<0.05$ & $<0.05$ & $<0.05$ & $<0.3$ & 2.5 & 13 & 10.4 & $<0.1$ & 3.01 \\
\hline TM-2 & B & $<0.06$ & $<0.3$ & $<0.06$ & $<0.06$ & $<0.06$ & $<0.3$ & 0.77 & $<0.06$ & 10.3 & 20 & 3.98 \\
\hline $\mathrm{RD}, \%$ & & - & - & - & - & - & - & 52.8 & - & 0.3 & - & 13.8 \\
\hline TM-3 & A & $<0.05$ & $<0.3$ & $<0.05$ & 0.50 & $<0.05$ & $<0.3$ & 2.7 & 6.7 & 9.44 & $<0.1$ & 3.67 \\
\hline TM-3 & B & $<0.05$ & $<0.3$ & 0.06 & $<0.05$ & 1.3 & $<0.3$ & 0.07 & 8.0 & 9.89 & 8.9 & 2.76 \\
\hline $\mathrm{RD}, \%$ & & - & - & - & - & - & - & 94.8 & 9.2 & 2.3 & - & 14.1 \\
\hline TM-4 & $\mathrm{A}$ & $<0.05$ & $<0.2$ & $<0.05$ & 1.1 & $<0.05$ & $<0.2$ & 11 & 7.0 & 9.82 & 9.5 & 5.87 \\
\hline TM-4 & B & $<0.05$ & $<0.2$ & 0.09 & 1.1 & $<0.05$ & $<0.2$ & 14 & 19 & 10.1 & $<0.1$ & 5.00 \\
\hline $\mathrm{RD}, \%$ & & - & - & - & - & - & - & 8.6 & 46.5 & 1.3 & - & 8.0 \\
\hline TM-5 & A & $<0.05$ & $<0.2$ & $<0.05$ & $<0.05$ & $<0.05$ & $<0.2$ & 0.42 & 4.0 & 8.79 & $<0.1$ & 2.85 \\
\hline TM-5 & B & $<0.05$ & $<0.2$ & $<0.05$ & 0.40 & $<0.05$ & $<0.2$ & 4.6 & 0.90 & 8.93 & $<0.1$ & 4.46 \\
\hline $\mathrm{RD}, \%$ & & - & - & - & - & - & - & 83.3 & 62.9 & 0.8 & - & 22.0 \\
\hline TM-6 & A & $<0.05$ & $<0.2$ & $<0.05$ & 2.5 & $<0.05$ & $<0.2$ & 24 & 12 & 8.97 & $<0.1$ & 2.75 \\
\hline TM-6 & B & $<0.05$ & $<0.3$ & $<0.05$ & 1.1 & 7.7 & $<0.3$ & 8.2 & 17 & 9.10 & $<0.1$ & 2.59 \\
\hline $\mathrm{RD}, \%$ & & - & - & - & - & - & - & 48.9 & 16.9 & 0.7 & - & 2.9 \\
\hline TM-7 & A & $<0.05$ & $<0.2$ & $<0.05$ & $<0.05$ & 3.1 & $<0.2$ & 0.49 & $<0.05$ & 8.82 & $<0.1$ & 1.42 \\
\hline TM-7 & B & $<0.05$ & $<0.2$ & $<0.05$ & 0.81 & $<0.05$ & $<0.2$ & 6.6 & $<0.05$ & 8.74 & $<0.1$ & 1.50 \\
\hline $\mathrm{RD}, \%$ & & - & - & - & - & - & - & 86.3 & - & 0.5 & - & 2.8 \\
\hline TM-8 & $\mathrm{A}$ & $<0.05$ & $<0.2$ & $<0.05$ & 0.38 & $<0.05$ & $<0.2$ & 5.2 & 2.5 & 8.68 & $<0.1$ & 1.55 \\
\hline TM-8 & B & $<0.05$ & $<0.2$ & $<0.05$ & 5.5 & $<0.05$ & $<0.2$ & 54 & 4.6 & 8.71 & $<0.1$ & 1.70 \\
\hline RD, \% & & - & - & - & 87.2 & - & - & 82.3 & 29.2 & 0.2 & & 4.6 \\
\hline TM-9 & A & $<0.05$ & $<0.2$ & $<0.05$ & 0.51 & $<0.05$ & $<0.2$ & 4.6 & $<0.05$ & 9.54 & $<0.1$ & 2.87 \\
\hline TM-9 & B & $<0.05$ & $<0.2$ & $<0.05$ & 2.7 & 1.2 & $<0.2$ & 29 & 7.8 & 9.50 & 13 & 2.92 \\
\hline RD, \% & & - & - & - & 68.1 & - & - & 72.6 & - & 0.2 & - & 0.9 \\
\hline
\end{tabular}


Table 31. Power Plant 2 ME-ST-M Duplicate Sample Trap Results, $\mu \mathrm{g} / \mathrm{dNm}^{3}$ at $3 \% \mathrm{O}_{2}$

\begin{tabular}{|c|c|c|c|c|c|c|c|c|c|c|c|c|}
\hline \multirow[b]{2}{*}{ Sample } & \multirow[b]{2}{*}{ Trap } & \multicolumn{11}{|c|}{ Metals } \\
\hline & & $\mathrm{Sb}$ & As & $\mathrm{Be}$ & $\mathrm{Cd}$ & $\mathrm{Cr}$ & $\mathrm{Co}$ & $\mathrm{Pb}$ & $\mathrm{Mn}$ & $\mathrm{Hg}$ & $\mathrm{Ni}$ & $\mathrm{Se}$ \\
\hline TM-3 & A & 0.53 & 7.17 & 0.11 & 0.06 & 3.05 & 0.47 & 8.74 & 13.2 & 9.52 & 2.27 & 9.51 \\
\hline TM-3 & B & 0.50 & 6.47 & 0.10 & 0.05 & 2.55 & 0.39 & 8.36 & 10.4 & 9.82 & 2.14 & 10.2 \\
\hline $\mathrm{RD}, \%$ & & 3.0 & 5.1 & 7.7 & 7.7 & 8.9 & 9.9 & 2.2 & 11.6 & 1.5 & 3.0 & 3.5 \\
\hline TM-4 & $\bar{A}$ & 0.54 & 8.51 & 0.12 & 0.05 & 18.7 & 0.58 & 8.92 & 14.3 & 9.73 & 9.34 & 10.5 \\
\hline TM-4 & B & 0.47 & 6.60 & 0.10 & 0.83 & 26.1 & 0.59 & 8.94 & 12.2 & 9.72 & 25.9 & 8.56 \\
\hline $\mathrm{RD}, \%$ & & 7.1 & 12.7 & 11.0 & $88.4^{*}$ & 16.5 & 0.3 & 0.1 & 8.1 & 0.0 & 47.0 & 10.1 \\
\hline TM-5 & A & 0.48 & 7.03 & 0.11 & 1.41 & 2.78 & 0.42 & 15.1 & 10.2 & 9.40 & 1.30 & 7.84 \\
\hline TM-5 & B & 0.58 & 8.39 & 0.14 & 1.08 & 3.11 & 0.57 & 12.1 & 16.0 & 10.1 & 1.18 & 6.95 \\
\hline $\mathrm{RD}, \%$ & & 8.9 & 8.8 & 11.0 & 13.1 & 5.5 & 14.4 & 10.8 & 22.3 & 3.4 & 4.8 & 6.0 \\
\hline TM-6 & $\bar{A}$ & 0.45 & 7.39 & 0.10 & 3.49 & 4.58 & 0.47 & 28.3 & 12.0 & 9.37 & 1.32 & 5.00 \\
\hline TM-6 & B & 0.50 & 7.95 & 0.10 & 1.08 & 2.88 & 0.50 & 19.9 & 12.3 & 9.15 & 0.92 & 7.51 \\
\hline $\mathrm{RD}, \%$ & & 5.7 & 3.7 & 2.8 & 52.6 & 22.7 & 3.3 & 17.5 & 1.2 & 1.2 & 17.8 & 20.0 \\
\hline TM-7 & $\bar{A}$ & 0.48 & 7.57 & 0.09 & 0.26 & 3.45 & 0.51 & 4.10 & 18.4 & 9.11 & 3.27 & 7.01 \\
\hline TM-7 & B & 0.61 & 11.1 & 0.14 & 0.05 & 4.48 & 0.68 & 21.1 & 4.31 & 9.32 & 3.48 & 7.81 \\
\hline $\mathrm{RD}, \%$ & & 11.5 & 19.0 & 21.0 & 65.6 & 13.0 & 13.8 & 67.4 & 62.0 & 1.1 & 3.2 & 5.4 \\
\hline TM-8 & $\bar{A}$ & 0.69 & 8.70 & 0.12 & 0.05 & 4.88 & 0.40 & 17.5 & 4.77 & 8.00 & 5.95 & 8.52 \\
\hline TM-8 & B & 0.74 & 9.85 & 0.13 & 0.07 & 4.17 & 0.55 & 26.8 & 5.23 & 8.62 & 1.99 & 9.43 \\
\hline $\mathrm{RD}, \%$ & & 3.8 & 6.2 & 3.4 & 12.8 & 7.7 & 16.4 & 21.1 & 4.6 & 3.7 & 49.8 & 5.1 \\
\hline TM-9 & A & 0.75 & 10.5 & 0.13 & 0.18 & 4.18 & 0.67 & 19.3 & 6.71 & 7.72 & 2.11 & 8.25 \\
\hline TM-9 & B & 0.81 & 10.1 & 0.13 & 0.11 & 4.19 & 0.67 & 18.8 & 6.74 & 8.09 & 2.11 & 9.77 \\
\hline $\mathrm{RD}, \%$ & & 3.7 & 1.5 & 0.4 & 21.8 & 0.1 & 0.0 & 1.1 & 0.3 & 2.4 & 0.0 & 8.4 \\
\hline TM-10 & $\mathrm{A}$ & 0.73 & 11.9 & 0.11 & 0.60 & 4.77 & 0.67 & 17.0 & 6.97 & 7.77 & 4.65 & 8.58 \\
\hline TM-10 & B & 0.64 & 9.21 & 0.09 & 0.08 & 4.81 & 0.48 & 16.2 & 5.39 & 8.21 & 0.72 & 8.46 \\
\hline $\mathrm{RD}, \%$ & & 6.8 & 12.6 & 7.5 & 76.3 & 0.4 & 16.6 & 2.5 & 12.7 & 2.7 & 73.1 & 0.7 \\
\hline TM-11 & $\mathrm{A}$ & 0.52 & 7.33 & 0.10 & 0.07 & 2.59 & 0.43 & 13.8 & 4.24 & 7.99 & 1.09 & 6.72 \\
\hline TM-11 & B & 0.48 & 6.89 & 0.09 & 0.09 & 2.15 & 0.30 & 13.8 & 3.95 & 8.53 & 2.60 & 6.77 \\
\hline $\mathrm{RD}, \%$ & & 3.8 & 3.1 & 4.1 & 10.2 & 9.3 & 17.4 & 0.1 & 3.5 & 3.3 & 40.9 & 0.3 \\
\hline
\end{tabular}

* Shaded values are those $>20 \%$.

Analysis of the trace metal samples was completed using ICP-MS. The following ASTM and EPA methods were employed for the preparation and analysis of the different samples: EPA SW846 3052 (Microwave Assisted Acid Digestion of Siliceous and Organically Based Matrices), SW-846 6020A (ICP-MS), and ASTM D6357 (Standard Test Methods for Determination of Trace Elements in Coal, Coke, and Combustion Residues from Coal Utilization Processes by ICP-AES, ICP-MS, and Graphite Furnace Atomic Absorption Spectrometry).

The ICP-MS was calibrated with a blank and a minimum of three standards which were prepared from commercially available stock standards traceable to the National Institute of Standards and Technology (NIST). The blank and standard diluent were $1 \% \mathrm{v} / \mathrm{v} \mathrm{HNO}_{3}$ prepared from concentrated trace metal-grade acid and ASTM Type I water. After calibration, an initial calibration verification (ICV) standard was run, which required a reading of $95 \%-105 \%$ of the actual value, or the instrument was recalibrated. The ICV was prepared from a separate source as the calibration standards. Calibration standards and ICVs were prepared daily. 
Table 32. Power Plant 3 ME-ST-M Duplicate Sample Trap Results, $\mu g / \mathrm{Nm}^{3}$ at $3 \% \mathrm{O}_{2}$

\begin{tabular}{|c|c|c|c|c|c|c|c|c|c|c|c|c|}
\hline & & & & & & & Metal & & & & & \\
\hline Sample & Trap & $\mathrm{Sb}$ & As & $\mathrm{Be}$ & $\mathrm{Cd}$ & $\mathrm{Cr}$ & Co & $\mathrm{Pb}$ & $\mathrm{Mn}$ & $\mathrm{Hg}$ & $\mathrm{Ni}$ & $\mathrm{Se}$ \\
\hline TM-1 & A & 0.76 & 23.9 & 0.86 & 0.18 & 12.8 & 1.38 & 2.67 & 159 & 2.54 & 6.13 & 5.29 \\
\hline TM-1 & B & 0.90 & 26.3 & 0.91 & 0.19 & 11.4 & 1.41 & 2.71 & 157 & 2.72 & 2.62 & 5.93 \\
\hline $\mathrm{RD}, \%$ & & 8.5 & 4.8 & 3.3 & 1.8 & 6.0 & 1.1 & 0.6 & 0.9 & 3.4 & $40.2 *$ & 5.7 \\
\hline TM-2 & $\bar{A}$ & 0.35 & 4.15 & 1.04 & 7.92 & 5.17 & 0.93 & 66.2 & 130 & 3.69 & 56.1 & 5.32 \\
\hline TM-2 & B & 0.29 & 2.76 & 0.21 & 0.03 & 84.4 & 1.42 & 0.30 & 122 & 3.65 & 110 & 4.09 \\
\hline $\mathrm{RD}, \%$ & & 9.4 & 20.2 & 65.8 & 99.2 & 88.5 & 20.9 & 99.1 & 3.1 & 0.6 & 32.5 & 13.1 \\
\hline TM-3 & A & 0.41 & 11.6 & 0.47 & 0.16 & 113 & 2.21 & 1.53 & 167 & 4.38 & 77.4 & 5.91 \\
\hline TM-3 & B & 0.45 & 7.16 & 0.25 & 0.11 & 3.94 & 0.55 & 1.13 & 67 & 4.57 & 1.38 & 5.65 \\
\hline $\mathrm{RD}, \%$ & & 4.0 & 23.7 & 31.1 & 19.6 & 93.3 & 60.0 & 15.1 & 43.0 & 2.1 & 96.5 & 2.3 \\
\hline TM-4 & $\mathrm{A}$ & 0.76 & 12.5 & 0.49 & 0.22 & 9.48 & 1.75 & 0.86 & 175 & 2.91 & 3.45 & 7.13 \\
\hline TM-4 & B & 0.58 & 11.2 & 0.43 & 0.17 & 9.12 & 1.49 & 0.90 & 155 & 3.02 & 5.90 & 6.69 \\
\hline $\mathrm{RD}, \%$ & & 13.5 & 5.7 & 6.0 & 13.3 & 2.0 & 8.0 & 2.3 & 6.1 & 1.9 & 26.2 & 3.2 \\
\hline TM-5 & $\mathrm{A}$ & 0.54 & 8.86 & 0.36 & 0.10 & 44.2 & 1.46 & 1.40 & 141 & 3.39 & 22.9 & 5.91 \\
\hline TM-5 & B & 0.62 & 9.19 & 0.41 & 0.05 & 60.1 & 1.92 & 1.49 & 180 & 3.26 & 59.7 & 6.22 \\
\hline $\mathrm{RD}, \%$ & & 6.6 & 1.8 & 6.3 & 29.3 & 15.3 & 13.6 & 3.2 & 12.0 & 2.0 & 44.6 & 2.5 \\
\hline TM-6 & $\bar{A}$ & 0.61 & 9.95 & 0.42 & 0.07 & 7.85 & 1.05 & 2.13 & 132 & 4.64 & 4.75 & 5.94 \\
\hline TM-6 & B & 0.69 & 12.5 & 0.50 & 0.31 & 11.7 & 1.65 & 1.95 & 164 & 4.43 & 10.6 & 5.86 \\
\hline $\mathrm{RD}, \%$ & & 6.7 & 11.3 & 8.9 & 63.8 & 19.8 & 22.2 & 4.5 & 10.9 & 2.3 & 37.9 & 0.7 \\
\hline TM-7 & A & 0.54 & 8.89 & 0.41 & 0.06 & 21.7 & 1.41 & 1.07 & 126 & 4.11 & 10.2 & 5.74 \\
\hline TM-7 & B & 0.46 & 6.76 & 0.32 & 0.04 & 7.60 & 0.55 & 14.0 & 51.5 & 4.01 & 0.72 & 5.00 \\
\hline $\mathrm{RD}, \%$ & & 7.6 & 13.6 & 11.8 & 25.1 & 48.2 & 43.8 & 85.9 & 42.0 & 1.3 & 86.8 & 6.9 \\
\hline TM-8 & $\bar{A}$ & 0.51 & 7.13 & 0.36 & 0.30 & 93.2 & 1.68 & 1.90 & 135 & 3.57 & 59.2 & 4.97 \\
\hline TM-8 & B & 0.63 & 12.9 & 0.50 & 0.14 & 7.17 & 1.52 & 1.65 & 127 & 4.00 & 2.39 & 5.23 \\
\hline $\mathrm{RD}, \%$ & & 10.5 & 28.8 & 16.1 & 35.7 & 85.7 & 5.1 & 7.0 & 3.0 & 5.7 & 92.2 & 2.5 \\
\hline TM-9 & A & 1.00 & 12.2 & 0.59 & 7.57 & 8.55 & 1.62 & 12.6 & 157 & 3.89 & 2.70 & 5.64 \\
\hline TM-9 & B & 0.56 & 11.6 & 0.62 & 0.05 & 6.45 & 1.27 & 0.96 & 138 & 3.71 & 7.11 & 5.37 \\
\hline $\mathrm{RD}, \%$ & & 28.7 & 2.3 & 2.2 & 98.7 & 13.9 & 12.0 & 85.9 & 6.4 & 2.4 & 44.9 & 2.5 \\
\hline
\end{tabular}

*Shaded values are those $>20 \%$.

A minimum of one sample out of every ten or one sample from each batch was analyzed in triplicate to determine instrument precision. Acceptable precision limits are $<10 \%$ RSD. All sample replicates for this project were within the acceptable limits of $<10 \%$ RSD. Analyte spikes of known concentrations were prepared for each sample matrix and analyzed at the same frequency to confirm analyte recovery from a particular matrix. The amount of analyte added was approximately equal to the amount found in the sample. The solution used for spiking was prepared from a stock separate from the calibration standards. Acceptable ranges for analyte recovery are $85 \%-115 \%$ for samples reading above the MDL and $50 \%-150 \%$ for samples reading below the MDL. All matrix spikes for this project were within the acceptable limits.

A continuing calibration verification (CCV) standard, prepared at a concentration equivalent to the midpoint range of the calibration curve, was run every ten samples and at the end of every run to check the slope of the calibration curve. If the CCV did not read $90 \%-110 \%$ of the true value, the instrument was recalibrated, and the samples since the last acceptable CCV were reanalyzed. 


\section{CONCLUSIONS AND RECOMMENDATIONS}

The following conclusions can be made comparing EPA M26A and the ME-ST-H method for measurement of $\mathrm{HCl}$ emissions from three lignite coal-fired power plant stacks:

1 Measured $\mathrm{HCl}$ stack concentrations were below MATS limits regardless of method used, and for two of the three sites, the concentration in the flue gas was less than $0.5 \mathrm{dppm}(\mathrm{v})$ at $3 \% \mathrm{O}_{2}$.

2 At Plants 1 and 2, the $\mathrm{HCl}$ emissions showed excellent agreement between EPA M26A and the ME-ST-H method, generally within 10\%. At Plant 3, however, the agreement was not as good; emissions were measured at below the M26A detection limit. This is likely a result of issues known to exist using EPA M26A in wet saturated stacks. Therefore, most likely the ME-ST-H values are correct. This conclusion is further supported by the good comparison to Plant 1, which has a similar configuration and burns a similar coal but does not have a saturated wet stack.

3 Paired ME-ST-H traps showed good agreement at all sites, generally less than $20 \%$ $\mathrm{RD}$, with much of the data showing less than $10 \% \mathrm{RD}$.

4 Redesign of the trap and material selection throughout the project reduced background contributions of $\mathrm{HCl}$ by a factor of over 10. Blank values are $\sim 100$ times lower than the MATS limit for new/reconstructed coal-fired units, assuming a 250-L sample volume.

Based on these conclusions, the ME-ST-H method shows promise as an alternative to EPA M26 or M26A.

The following conclusions can be drawn for the tests using the ME-ST-M method:

1. For Plant 1 (ESP-wet FGD), stack metal concentrations were below the MATS limit for existing coal-fired units, except for mercury. Many of the metals measured in the stack for Plant 2 (ESP only) and Plant 3 were above the MATS limit. Sb, As, Be, Cd, and Co often fell below EPA M29 detection limits. The ME-ST-M method showed improved (lower) detection limits for these metals. This problem becomes more evident as the limits are tightened (lowered) for new or reconstructed plants.

2. Concentrations measured for $\mathrm{Sb}, \mathrm{As}, \mathrm{Cd}$, and Co that were above the MATS limit showed good agreement between EPA M29 and the ME-ST-M method, generally within $20 \%$. Field blank value for this set of data is less of an issue, as measured values are significantly larger than blank values.

3. $\mathrm{Ni}, \mathrm{Pb}, \mathrm{Cr}$, and $\mathrm{Mn}$ results showed poorer and more variable comparability between EPA M29 and the ME-ST-M method, likely because of the background concentrations of these metals in the sorbent trap material and M29 reagents. However, for all metals, the RDs between EPA M29 and the ME-ST-M method were generally $<50 \%$ RD, with 
many $<20 \%$ RD. Although much improvement has been made in the sorbent trap background, additional effort is still needed to reduce these metals further.

4. $\mathrm{Ni}, \mathrm{Pb}, \mathrm{Cr}$, and $\mathrm{Mn}$ results showed a higher degree of variability for M29 compared to the other metals, likely because of background contamination. Reagents for cleaning glassware must be replaced more frequently and glassware must be new or cleaned with extreme care. Front- and back-half glassware should be kept separate for reuse to minimize contamination. Consideration should be given to eliminate permanganate impingers to reduce possible Mn contamination and measure Hg using M30b.

5. Comparison of the dual ME-ST traps for $\mathrm{Hg}$ and Se shows good agreement, $\leq 20 \% \mathrm{RD}$ and generally less than $10 \%$ RD. Although, as shown in Appendix C, the comparison for other metals showed more variability, the majority of the duplicate traps were within the $\leq 20 \%$ RD. A significant low bias in selenium for the ME-ST-M method relative to EPA M29 was observed at Plant 2; more investigation is needed to explain this finding.

6. For many of the metals, field blank data for M29 and ME-ST-M were near to measured values and higher than MATS limits. Consequently, reducing contamination and/or extending sampling durations is essential.

Based on these conclusions, additional research is still needed to explore possible longer sampling durations and/or selection of lower-background materials before the ME-ST-M method can be considered as a potential alternative method to M29 to demonstrate compliance for all of the trace metals listed in MATS.

Based on the results of the tests comparing the ME-ST methods with EPA M26A and $\mathrm{M} 29$, the following recommendations are made for future testing:

1. Perform additional tests at plants burning subbituminous and bituminous coals. Evaluate the effect of different plant configurations on the applicability of the ME-ST method, in particular, selective noncatalytic reduction, selective catalytic reduction, dry scrubbers, and fabric filters.

2. Continue to refine the sampling and analysis process to improve (lower) detection limits.

3. Evaluate other sorbent trap materials (ME-ST-M) or chemical reagents (M29) to lower background contributions of $\mathrm{Pb}, \mathrm{Ni}, \mathrm{Cr}$, and $\mathrm{Mn}$.

4. Evaluate longer sampling duration (4+ hours) to improve the accuracy for ME-ST metal traps and EPA M29. A longer sampling duration would provide a greater sample mass compared to the blank levels.

5. Evaluate the potential impact of a shorter sampling duration ( 1 hour or less) on the accuracy of the ME-ST halogen $(\mathrm{HCl})$ traps. 
6. Explore the possibility of extending the ME-ST halogen traps to be used as a continuous monitor approach for $\mathrm{HCl}$.

7. Publish the detailed method and seek formal EPA approval and acceptance as an alternative reference method.

\section{REFERENCES}

1. National Emission Standards for Hazardous Air Pollutants from Coal- and Oil-Fired Electric Utility Steam Generating Units and Standards of Performance for Fossil-Fuel-Fired Electric Utility, Industrial-Commercial-Institutional, and Small Industrial-Commercial-Institutional Steam Generating Units: Final Rule (Mercury and Air Toxics Standards [MATS]). 40 Code of Federal Regulations, Parts 60 and 63; Fed Regist. 2012, 77 (32), 9304.

2. Reconsideration of Certain New Source Issues: National Emission Standards for Hazardous Air Pollutants from Coal- and Oil-Fired Electric Utility Steam Generating Units and Standards of Performance for Fossil-Fuel-Fired Electric Utility, Industrial-CommercialInstitutional, and Small Industrial-Commercial-Institutional Steam Generating Units: Final Rule (Mercury and Air Toxics Standards [MATS]). 40 Code of Federal Regulations, Parts 60 and 63; Fed Regist. 2012, 78 (79), 24073.

3. U.S. Environmental Protection Agency. National Emission Standards for Hazardous Air Pollutants for Major Sources: Industrial, Commercial, and Institutional Boilers and Process Heaters. Fed. Regist. 2013, 78 (21).

4. Lentz, N.B.; Pavlish, J.H. Development of a Multielement Sorbent Trap Sampling Method. In Proceedings of Air Quality VIII: An International Conference on Carbon Management, Mercury, Trace Substances, $\mathrm{SO}_{x}, \mathrm{NO}_{x}$, and Particulate Matter; Arlington, VA, Oct 24-27, 2011.

5. U.S. Environmental Protection Agency. Method 26A - Determination of Hydrogen Halide and Halogen Emissions from Stationary Sources-Isokinetic Method. 40 Code of Federal Regulations, Part 60, Appendix A-8, Method 26A (issued March 3, 1994).

6. Sun, J.Q.; Crocker, C.R.; Lillemoen, C.M. The Effect of Coal Combustion Flue Gas Components on Low-Level Chlorine Speciation Using EPA Method 26A. J. Air Waste Manage. Assoc. 2000, 50 (6), 936-40.

7. Johnson, L.D. Stack Sampling Methods for Halogens and Halogen Acids. Presented at the EPA/AWMA International Symposium on Measurement of Toxic and Related Air Pollutants, Research Triangle Park, NC, May 1996.

8. U.S. Environmental Protection Agency. M29 - Determination of Metals Emissions from Stationary Sources. 40 Code of Federal Regulations, Part 60, Appendix A-8, M29 (issued June 25, 1996). 
9. Standard Methods for the Examination of Water and Wastewater, 19th Ed.; 1995, 1030 E. Method Detection Level, pp 1-10.

10. EPRI's Comments on Proposed HAPs MACT Rule. U.S. Environmental Protection Agency Docket ID: EPA-HQ-OAR-2009-0234, Aug 4, 2011.

11. EPRI's Comments on Proposed Reconsideration of Utility MATs Rule. U.S. Environmental Protection Agency, Docket ID: No. EPA-HQ-OAR-2009-0234, Jan 7, 2013.

12. Site-Specific Test Plan: Field Evaluation of Novel Approach for Obtaining Metal Emission Data, Site 1, Aug 2011.

13. Site-Specific Test Plan: Field Evaluation of Novel Approach for Obtaining Metal Emission Data, Site 2, June 2012.

14. Site-Specific Test Plan: Field Evaluation of Novel Approach for Obtaining Metal Emission Data, Site 3, Jan 2013; 4337190006851021.

15. U.S. Environmental Protection Agency. Method 301-Field Validation of Pollutant Measurement Methods from Various Waste Media. 40 Code of Federal Regulations, Part 63, Fed. Regist. 2011, 76 (96), 28664. 
APPENDIX A

\section{COMPLETE COAL DATA}


Table A-1. Plant 1, Coal Data

\begin{tabular}{|c|c|c|c|c|c|c|c|c|c|}
\hline $\begin{array}{l}\text { Date: } \\
\text { Time: }\end{array}$ & & $\begin{array}{c}8 / 23 / 2011 \\
12: 00 \\
\end{array}$ & $\begin{array}{c}8 / 23 / 2011 \\
17: 00 \\
\end{array}$ & $\begin{array}{c}8 / 24 / 2011 \\
11: 15 \\
\end{array}$ & $\begin{array}{c}8 / 24 / 2011 \\
16: 14 \\
\end{array}$ & $\begin{array}{c}8 / 25 / 2011 \\
10: 00 \\
\end{array}$ & $\begin{array}{c}8 / 25 / 2011 \\
16: 00 \\
\end{array}$ & Average & $\begin{array}{c}\text { Standard } \\
\text { Deviation }\end{array}$ \\
\hline \multicolumn{10}{|l|}{ Proximate } \\
\hline Moisture & $\%^{\mathrm{a}}$ & 32.81 & 32.37 & 32.34 & 33.38 & 32.37 & 31.77 & 32.51 & 0.54 \\
\hline Volatile Matter & $\%$ & 23.00 & 23.82 & 22.14 & 23.32 & 22.80 & 22.69 & 22.96 & 0.57 \\
\hline Fixed Carbon & $\%$ & 35.00 & 34.78 & 34.30 & 35.15 & 34.02 & 31.92 & 34.19 & 1.19 \\
\hline Ash & $\%$ & 9.19 & 9.03 & 11.22 & 8.15 & 10.81 & 13.62 & 10.34 & 1.98 \\
\hline \multicolumn{10}{|l|}{ Ultimate } \\
\hline $\mathrm{H}$ & $\%$ & 6.65 & 6.54 & 6.45 & 6.76 & 6.50 & 6.26 & 6.53 & 0.17 \\
\hline $\mathrm{C}$ & $\%$ & 39.43 & 38.64 & 37.08 & 39.60 & 38.59 & 36.15 & 38.25 & 1.36 \\
\hline $\mathrm{N}$ & $\%$ & 0.57 & 0.56 & 0.55 & 0.57 & 0.57 & 0.53 & 0.56 & 0.02 \\
\hline $\mathrm{S}$ & $\%$ & 0.66 & 0.71 & 0.98 & 0.79 & 0.75 & 0.85 & 0.79 & 0.11 \\
\hline $\mathrm{O}$ & $\%$ & 43.49 & 44.52 & 43.71 & 44.12 & 42.78 & 42.59 & 43.54 & 0.75 \\
\hline Heating Value & $\mathrm{Btu} / \mathrm{lb}$ & 6355 & 6412 & 6130 & 6574 & 6262 & 5996 & 6288 & 206 \\
\hline $\mathrm{F}_{\mathrm{d}}$ & $\mathrm{dscf} / 10^{6} \mathrm{Btu}$ & 10,277 & 9863 & 9960 & 10,001 & 10,196 & 9898 & 10,033 & 167 \\
\hline $\mathrm{H}$ & $\%^{\mathrm{b}}$ & 2.98 & 2.92 & 2.83 & 3.02 & 2.88 & 2.70 & 2.89 & 0.12 \\
\hline $\mathrm{O}$ & $\%{ }^{b}$ & 14.36 & 15.77 & 14.99 & 14.48 & 14.03 & 14.38 & 14.67 & 0.62 \\
\hline
\end{tabular}


Table A-2. Plant 1, Coal Halogens and Trace Element Data

\begin{tabular}{|c|c|c|c|c|c|c|c|c|c|}
\hline $\begin{array}{l}\text { Date: } \\
\text { Time: }\end{array}$ & & $\begin{array}{c}8 / 23 / 2011 \\
12: 00 \\
\end{array}$ & $\begin{array}{c}8 / 23 / 2011 \\
17: 00 \\
\end{array}$ & $\begin{array}{c}8 / 24 / 2011 \\
11: 15 \\
\end{array}$ & $\begin{array}{c}8 / 24 / 2011 \\
16: 14 \\
\end{array}$ & $\begin{array}{c}8 / 25 / 2011 \\
10: 00 \\
\end{array}$ & $\begin{array}{c}8 / 25 / 2011 \\
16: 00 \\
\end{array}$ & Average & $\begin{array}{c}\text { Standard } \\
\text { Deviation }\end{array}$ \\
\hline \multicolumn{10}{|c|}{ Halogens } \\
\hline $\mathrm{Cl}$ & $\mu \mathrm{g} / \mathrm{g}(\mathrm{dry})$ & 19.4 & 19.2 & 15.9 & 26.2 & 16.1 & 18.7 & 19.3 & 3.7 \\
\hline $\mathrm{F}$ & $\mu \mathrm{g} / \mathrm{g}$ (dry) & 117 & 117 & 145 & 118 & 131 & 144 & 129 & 13 \\
\hline $\mathrm{Br}$ & $\mu \mathrm{g} / \mathrm{g}$ (dry) & 13.7 & 6.3 & 15.1 & 6.5 & 7.7 & 5.7 & 9.2 & 4.1 \\
\hline \multicolumn{10}{|c|}{ Metals } \\
\hline $\mathrm{Sb}$ & $\mu \mathrm{g} / \mathrm{g}$ (dry) & 0.81 & 0.69 & 1.1 & 0.76 & 0.70 & 0.84 & 0.82 & 0.15 \\
\hline As & $\mu \mathrm{g} / \mathrm{g}$ (dry) & 9.2 & 11 & 16 & 12 & 12 & 13 & 12 & 2 \\
\hline $\mathrm{Be}$ & $\mu \mathrm{g} / \mathrm{g}$ (dry) & 0.674 & 0.624 & 0.830 & 0.564 & 0.624 & 0.725 & 0.674 & 0.094 \\
\hline $\mathrm{Cd}$ & $\mu \mathrm{g} / \mathrm{g}$ (dry) & 0.14 & 0.13 & 0.19 & 0.13 & 0.14 & 0.17 & 0.15 & 0.02 \\
\hline $\mathrm{Cr}$ & $\mu \mathrm{g} / \mathrm{g}$ (dry) & 14.9 & 14.0 & 18.5 & 11.6 & 17.0 & 21.5 & 16.3 & 3.5 \\
\hline $\mathrm{Co}$ & $\mu \mathrm{g} / \mathrm{g}$ (dry) & 2.33 & 2.17 & 2.33 & 1.92 & 2.51 & 2.96 & 2.37 & 0.35 \\
\hline $\mathrm{Pb}$ & $\mu \mathrm{g} / \mathrm{g}$ (dry) & 4.06 & 4.26 & 5.45 & 4.91 & 4.61 & 5.60 & 4.82 & 0.62 \\
\hline $\mathrm{Mn}$ & $\mu \mathrm{g} / \mathrm{g}$ (dry) & 70.1 & 73.9 & 65.6 & 63.8 & 81.4 & 83.7 & 73.1 & 8.2 \\
\hline $\mathrm{Hg}$ & $\mu \mathrm{g} / \mathrm{g}$ (dry) & 0.0781 & 0.0925 & 0.119 & 0.107 & 0.0954 & 0.119 & 0.102 & 0.016 \\
\hline $\mathrm{Ni}$ & $\mu \mathrm{g} / \mathrm{g}$ (dry) & 6.90 & 6.93 & 8.19 & 36.8 & 12.3 & 10.5 & 13.60 & 11.56 \\
\hline $\mathrm{Se}$ & $\mu \mathrm{g} / \mathrm{g}$ (dry) & 0.57 & 0.54 & 0.67 & 0.65 & 0.58 & 0.71 & 0.62 & 0.07 \\
\hline
\end{tabular}


Table A-3a. Plant 1, Calculated Uncontrolled Emissions from Coal

\begin{tabular}{|c|c|c|c|c|c|c|c|c|c|}
\hline $\begin{array}{l}\text { Date: } \\
\text { Time: }\end{array}$ & & $\begin{array}{c}8 / 23 / 2011 \\
12: 00 \\
\end{array}$ & $\begin{array}{c}8 / 23 / 2011 \\
17: 00 \\
\end{array}$ & $\begin{array}{c}8 / 24 / 2011 \\
11: 15 \\
\end{array}$ & $\begin{array}{c}8 / 24 / 2011 \\
16: 14 \\
\end{array}$ & $\begin{array}{c}8 / 25 / 2011 \\
10: 00 \\
\end{array}$ & $\begin{array}{c}8 / 25 / 2011 \\
16: 00 \\
\end{array}$ & Average & $\begin{array}{l}\text { Standard } \\
\text { Deviation }\end{array}$ \\
\hline \multicolumn{10}{|c|}{ Halogens } \\
\hline $\mathrm{HCl}$ & ppmv* & 1.89 & 1.95 & 1.67 & 2.52 & 1.62 & 2.04 & 1.95 & 0.32 \\
\hline $\mathrm{HF}$ & ppmv* & 21.3 & 22.1 & 28.4 & 21.1 & 24.5 & 29.3 & 24.5 & 3.6 \\
\hline $\mathrm{HBr}$ & ppmv* & 0.59 & 0.28 & 0.70 & 0.28 & 0.34 & 0.28 & 0.41 & 0.19 \\
\hline \multicolumn{10}{|c|}{ Metals } \\
\hline $\mathrm{Sb}$ & $\mu \mathrm{g} / \mathrm{dNm}^{3 *}$ & 114 & 101 & 167 & 106 & 102 & 133 & 121 & 26 \\
\hline As & $\mu \mathrm{g} / \mathrm{dNm}^{3 *}$ & 1300 & 1615 & 2434 & 1669 & 1745 & 2052 & 1802 & 393 \\
\hline $\mathrm{Be}$ & $\mu \mathrm{g} / \mathrm{dNm}^{3 *}$ & 95 & 92 & 126 & 78 & 91 & 114 & 99 & 18 \\
\hline $\mathrm{Cd}$ & $\mu \mathrm{g} / \mathrm{dNm}^{3 *}$ & 20 & 19 & 29 & 18 & 20 & 27 & 22 & 5 \\
\hline $\mathrm{Cr}$ & $\mu \mathrm{g} / \mathrm{dNm}^{3 *}$ & 2105 & 2055 & 2815 & 1614 & 2472 & 3393 & 2409 & 630 \\
\hline $\mathrm{Co}$ & $\mu \mathrm{g} / \mathrm{dNm}^{3 *}$ & 329 & 319 & 354 & 267 & 365 & 467 & 350 & 67 \\
\hline $\mathrm{Pb}$ & $\mu \mathrm{g} / \mathrm{dNm}^{3 *}$ & 573 & 625 & 829 & 683 & 670 & 884 & 711 & 120 \\
\hline $\mathrm{Mn}$ & $\mu \mathrm{g} / \mathrm{dNm}^{3 *}$ & 9902 & 10,849 & 9980 & 8876 & 11,836 & 13,211 & 10,776 & 1553 \\
\hline $\mathrm{Hg}$ & $\mu \mathrm{g} / \mathrm{dNm}^{3} *$ & 11.0 & 13.6 & 18.1 & 14.9 & 13.9 & 18.8 & 15.0 & 2.9 \\
\hline $\mathrm{Ni}$ & $\mu \mathrm{g} / \mathrm{dNm}^{3 *}$ & 975 & 1017 & 1246 & 5120 & 1789 & 1657 & 1967 & 1579 \\
\hline $\mathrm{Se}$ & $\mu \mathrm{g} / \mathrm{dNm}^{3 *}$ & 81 & 79 & 102 & 90 & 84 & 112 & 91 & 13 \\
\hline
\end{tabular}

$*$ At $3 \% \mathrm{O}_{2}$. 
Table A-3b. Plant 1, Calculated Uncontrolled Emissions from Coal

\begin{tabular}{|c|c|c|c|c|c|c|c|c|c|}
\hline $\begin{array}{l}\text { Date: } \\
\text { Time: }\end{array}$ & & $\begin{array}{c}8 / 23 / 2011 \\
12: 00 \\
\end{array}$ & $\begin{array}{c}8 / 23 / 2011 \\
17: 00 \\
\end{array}$ & $\begin{array}{c}8 / 24 / 2011 \\
11: 15 \\
\end{array}$ & $\begin{array}{c}8 / 24 / 2011 \\
16: 14 \\
\end{array}$ & $\begin{array}{c}8 / 25 / 2011 \\
10: 00 \\
\end{array}$ & $\begin{array}{c}8 / 25 / 2011 \\
16: 00 \\
\end{array}$ & Average & $\begin{array}{c}\text { Standard } \\
\text { Deviation }\end{array}$ \\
\hline \multicolumn{10}{|c|}{ Halogens } \\
\hline $\mathrm{HCl}$ & lb/TBtu & 2110 & 2083 & 1805 & 2731 & 1788 & 2188 & 2117 & 343 \\
\hline $\mathrm{HF}$ & lb/TBtu & 13027 & 12995 & 16854 & 12593 & 14898 & 17256 & 14604 & 2064 \\
\hline $\mathrm{HBr}$ & lb/TBtu & 1467 & 673 & 1688 & 667 & 842 & 657 & 999 & 459 \\
\hline \multicolumn{10}{|l|}{ Metals } \\
\hline $\mathrm{Be}$ & lb/TBtu & 71 & 66 & 92 & 57 & 67 & 83 & 73 & 12 \\
\hline $\mathrm{Cd}$ & lb/TBtu & 14.8 & 13.7 & 21.0 & 13.2 & 15.1 & 19.3 & 16.2 & 3.2 \\
\hline $\mathrm{Cr}$ & lb/TBtu & 1575 & 1477 & 2042 & 1176 & 1836 & 2447 & 1759 & 450 \\
\hline $\mathrm{Co}$ & lb/TBtu & 246 & 229 & 257 & 195 & 271 & 337 & 256 & 48 \\
\hline $\mathrm{Pb}$ & lb/TBtu & 429 & 449 & 602 & 498 & 498 & 637 & 519 & 83 \\
\hline $\mathrm{Se}$ & lb/TBtu & 60.3 & 57.0 & 74.0 & 65.9 & 62.6 & 80.8 & 66.7 & 9.0 \\
\hline
\end{tabular}


Table A-4. Plant 2, Coal Data

\begin{tabular}{|c|c|c|c|c|c|c|c|c|c|}
\hline $\begin{array}{l}\text { Date: } \\
\text { Time: }\end{array}$ & & $\begin{array}{c}6 / 5 / 12 \\
12: 00 \\
\end{array}$ & $\begin{array}{c}6 / 5 / 12 \\
8: 00 \\
\end{array}$ & $\begin{array}{c}6 / 6 / 12 \\
12: 00 \\
\end{array}$ & $\begin{array}{c}6 / 6 / 12 \\
8: 00 \\
\end{array}$ & $\begin{array}{c}6 / 7 / 12 \\
12: 00 \\
\end{array}$ & $\begin{array}{c}6 / 7 / 12 \\
8: 00 \\
\end{array}$ & Average & $\begin{array}{c}\text { Standard } \\
\text { Deviation }\end{array}$ \\
\hline \multicolumn{10}{|l|}{ Proximate } \\
\hline $\begin{array}{l}\text { Moisture } \\
\text { Volatile }\end{array}$ & $\%^{\mathrm{a}}$ & 35.07 & 35.81 & 34.77 & 35.07 & 35.13 & 35.02 & 35.15 & 0.35 \\
\hline Matter & $\%$ & 24.55 & 23.25 & 23.17 & 23.62 & 24.43 & 23.76 & 23.80 & 0.58 \\
\hline Fixed Carbon & $\%$ & 33.86 & 34.64 & 34.57 & 35.33 & 34.35 & 34.37 & 34.52 & 0.48 \\
\hline Ash & $\%$ & 6.52 & 6.30 & 7.48 & 5.97 & 6.09 & 6.86 & 6.54 & 0.56 \\
\hline \multicolumn{10}{|l|}{ Ultimate } \\
\hline $\mathrm{H}$ & $\%$ & 6.98 & 7.05 & 6.96 & 7.00 & 6.97 & 6.96 & 6.99 & 0.03 \\
\hline $\mathrm{C}$ & $\%$ & 41.41 & 40.41 & 40.78 & 41.15 & 41.64 & 40.68 & 41.01 & 0.47 \\
\hline $\mathrm{N}$ & $\%$ & 0.53 & 0.52 & 0.52 & 0.52 & 0.53 & 0.51 & 0.52 & 0.01 \\
\hline S & $\%$ & 0.97 & 1.09 & 0.97 & 1.10 & 1.02 & 0.85 & 1.00 & 0.09 \\
\hline $\mathrm{O}$ & $\%$ & 43.59 & 44.62 & 43.30 & 44.25 & 43.75 & 44.15 & 43.94 & 0.48 \\
\hline Heating Value & $\mathrm{Btu} / \mathrm{lb}$ & 6788 & 6673 & 6658 & 6870 & 6919 & 6716 & 6771 & 107 \\
\hline$F_{d}$ & $\mathrm{dscf} / 10^{6} \mathrm{Btu}$ & 10,264 & 10,190 & 10,328 & 10,061 & 10,109 & 10,148 & 10,183 & 99 \\
\hline $\mathrm{H}$ & $\%^{\mathrm{b}}$ & 3.06 & 3.04 & 3.07 & 3.08 & 3.04 & 3.04 & 3.05 & 0.02 \\
\hline $\mathrm{O}$ & $\%{ }^{\mathrm{b}}$ & 12.44 & 12.82 & 12.42 & 13.10 & 12.55 & 13.05 & 12.73 & 0.30 \\
\hline
\end{tabular}

${ }^{\mathrm{a}}$ As received unless otherwise noted.

${ }^{\mathrm{b}}$ Values not including moisture. 
Table A-5. Plant 2, Coal Halogens and Trace Element Data

\begin{tabular}{|c|c|c|c|c|c|c|c|c|c|}
\hline $\begin{array}{l}\text { Date: } \\
\text { Time: }\end{array}$ & & $\begin{array}{c}6 / 5 / 12 \\
12: 00 \\
\end{array}$ & $\begin{array}{c}6 / 5 / 12 \\
8: 00 \\
\end{array}$ & $\begin{array}{l}6 / 6 / 12 \\
12: 00 \\
\end{array}$ & $\begin{array}{c}6 / 6 / 12 \\
8: 00 \\
\end{array}$ & $\begin{array}{l}6 / 7 / 12 \\
12: 00 \\
\end{array}$ & $\begin{array}{c}6 / 7 / 12 \\
8: 00 \\
\end{array}$ & Average & $\begin{array}{l}\text { Standard } \\
\text { Deviation }\end{array}$ \\
\hline \multicolumn{10}{|c|}{ Halogens } \\
\hline $\mathrm{Cl}$ & $\mu \mathrm{g} / \mathrm{g}$ (dry) & 9.7 & 15.5 & 12.9 & 11 & 14.3 & 14.1 & 12.9 & 2.2 \\
\hline $\mathrm{F}$ & $\mu \mathrm{g} / \mathrm{g}$ (dry) & $<60$ & $<60$ & $<60$ & $<60$ & $<60$ & $<60$ & $<60$ & \\
\hline $\mathrm{Br}$ & $\mu \mathrm{g} / \mathrm{g}$ (dry) & $<6$ & $<6$ & $<6$ & $<6$ & $<6$ & $<6$ & $<6$ & \\
\hline \multicolumn{10}{|c|}{ Metals } \\
\hline $\mathrm{Sb}$ & $\mu \mathrm{g} / \mathrm{g}$ (dry) & 0.24 & 0.23 & 0.30 & 0.25 & 0.28 & 0.32 & 0.27 & 0.04 \\
\hline As & $\mu \mathrm{g} / \mathrm{g}$ (dry) & 3.04 & 2.77 & 4.49 & 3.11 & 3.15 & 2.66 & 3.20 & 0.66 \\
\hline $\mathrm{Be}$ & $\mu \mathrm{g} / \mathrm{g}$ (dry) & 0.076 & 0.135 & 0.165 & 0.132 & 0.12 & 0.198 & 0.138 & 0.041 \\
\hline $\mathrm{Cd}$ & $\mu \mathrm{g} / \mathrm{g}$ (dry) & 0.051 & 0.049 & 0.054 & 0.049 & 0.044 & 0.052 & 0.050 & 0.003 \\
\hline $\mathrm{Cr}$ & $\mu \mathrm{g} / \mathrm{g}$ (dry) & 6.37 & 8.14 & 7.43 & 10.3 & 11.2 & 10.3 & 8.96 & 1.91 \\
\hline $\mathrm{Co}$ & $\mu \mathrm{g} / \mathrm{g}$ (dry) & 0.933 & 0.886 & 1.06 & 0.964 & 0.924 & 0.992 & 0.960 & 0.061 \\
\hline $\mathrm{Pb}$ & $\mu \mathrm{g} / \mathrm{g}$ (dry) & 1.49 & 1.62 & 1.54 & 1.33 & 1.41 & 1.88 & 1.55 & 0.19 \\
\hline $\mathrm{Mn}$ & $\mu \mathrm{g} / \mathrm{g}$ (dry) & 40.9 & 55.3 & 37.2 & 31.9 & 34.5 & 29.5 & 38.2 & 9.3 \\
\hline $\mathrm{Hg}$ & $\mu \mathrm{g} / \mathrm{g}$ (dry) & 0.0831 & 0.0813 & 0.0678 & 0.0904 & 0.0772 & 0.0622 & 0.0770 & 0.0104 \\
\hline $\mathrm{Ni}$ & $\mu \mathrm{g} / \mathrm{g}$ (dry) & 4.75 & 3.98 & 4.55 & 8.09 & 7.17 & 5.89 & 5.74 & 1.62 \\
\hline $\mathrm{Se}$ & $\mu \mathrm{g} / \mathrm{g}$ (dry) & 0.52 & 0.64 & 0.61 & 0.49 & 0.44 & 0.48 & 0.53 & 0.08 \\
\hline
\end{tabular}


Table A-6a. Plant 2, Calculated Uncontrolled Emissions from Coal

\begin{tabular}{|c|c|c|c|c|c|c|c|c|c|}
\hline $\begin{array}{l}\text { Date: } \\
\text { Time: }\end{array}$ & & $\begin{array}{c}6 / 5 / 2012 \\
12: 00 \\
\end{array}$ & $\begin{array}{c}6 / 5 / 2012 \\
8: 00 \\
\end{array}$ & $\begin{array}{c}6 / 6 / 2012 \\
12: 00 \\
\end{array}$ & $\begin{array}{c}6 / 6 / 2012 \\
8: 00 \\
\end{array}$ & $\begin{array}{c}6 / 7 / 2012 \\
12: 00 \\
\end{array}$ & $\begin{array}{c}6 / 7 / 2012 \\
8: 00 \\
\end{array}$ & Average & $\begin{array}{c}\text { Standard } \\
\text { Deviation }\end{array}$ \\
\hline \multicolumn{10}{|c|}{ Halogens } \\
\hline $\mathrm{HCl}$ & ppmv* & 0.86 & 1.39 & 1.16 & 0.98 & 1.26 & 1.27 & 1.15 & 0.20 \\
\hline $\mathrm{HF}$ & ppmv* & $<10$ & $<10$ & $<10$ & $<10$ & $<10$ & $<10$ & $<10$ & \\
\hline $\mathrm{HBr}$ & ppmv* & $<0.2$ & $<0.2$ & $<0.2$ & $<0.2$ & $<0.2$ & $<0.2$ & $<0.2$ & \\
\hline \multicolumn{10}{|l|}{ Metals } \\
\hline $\mathrm{Sb}$ & $\mu \mathrm{g} / \mathrm{dNm}^{3 *}$ & 31 & 30 & 39 & 32 & 36 & 42 & 35 & 5 \\
\hline As & $\mu \mathrm{g} / \mathrm{dNm}^{3 *}$ & 389 & 359 & 585 & 401 & 401 & 348 & 414 & 87 \\
\hline $\mathrm{Be}$ & $\mu \mathrm{g} / \mathrm{dNm}^{3} *$ & 9.7 & 17.5 & 21.5 & 17.0 & 15.3 & 25.9 & 17.8 & 5.5 \\
\hline $\mathrm{Cd}$ & $\mu \mathrm{g} / \mathrm{dNm}^{3 *}$ & 6.5 & 6.4 & 7.0 & 6.3 & 5.6 & 6.8 & 6.44 & 0.49 \\
\hline $\mathrm{Cr}$ & $\mu \mathrm{g} / \mathrm{dNm}^{3} *$ & 815 & 1055 & 968 & 1328 & 1426 & 1348 & 1157 & 246 \\
\hline $\mathrm{Co}$ & $\mu \mathrm{g} / \mathrm{dNm}^{3} *$ & 119 & 115 & 138 & 124 & 118 & 130 & 124 & 9 \\
\hline $\mathrm{Pb}$ & $\mu \mathrm{g} / \mathrm{dNm}^{3} *$ & 191 & 210 & 201 & 172 & 180 & 246 & 200 & 27 \\
\hline $\mathrm{Mn}$ & $\mu \mathrm{g} / \mathrm{dNm}^{3 *}$ & 5233 & 7167 & 4845 & 4114 & 4393 & 3861 & 4935 & 1200 \\
\hline $\mathrm{Hg}$ & $\mu \mathrm{g} / \mathrm{dNm}^{3 *}$ & 10.6 & 10.5 & 8.83 & 11.7 & 9.83 & 8.14 & 9.94 & 1.29 \\
\hline $\mathrm{Ni}$ & $\mu \mathrm{g} / \mathrm{dNm}^{3 *}$ & 608 & 516 & 593 & 1043 & 913 & 771 & 741 & 206 \\
\hline $\mathrm{Se}$ & $\mu \mathrm{g} / \mathrm{dNm}^{3} *$ & 67 & 83 & 79 & 63 & 56 & 63 & 68 & 10 \\
\hline
\end{tabular}

*At 3\% $\mathrm{O}_{2}$. 
Table A-6b. Plant 2, Calculated Uncontrolled Emissions from Coal

\begin{tabular}{|c|c|c|c|c|c|c|c|c|c|}
\hline $\begin{array}{l}\text { Date: } \\
\text { Time: }\end{array}$ & & $\begin{array}{c}6 / 5 / 2012 \\
12: 00 \\
\end{array}$ & $\begin{array}{c}6 / 5 / 2012 \\
8: 00\end{array}$ & $\begin{array}{c}6 / 6 / 2012 \\
12: 00\end{array}$ & $\begin{array}{c}6 / 6 / 2012 \\
8: 00\end{array}$ & $\begin{array}{c}6 / 7 / 2012 \\
12: 00\end{array}$ & $\begin{array}{c}6 / 7 / 2012 \\
8: 00 \\
\end{array}$ & Average & $\begin{array}{l}\text { Standard } \\
\text { Deviation }\end{array}$ \\
\hline \multicolumn{10}{|c|}{ Halogens } \\
\hline $\mathrm{HCl}$ & $\mathrm{lb} / \mathrm{TB} t \mathrm{u}$ & 954 & 1533 & 1300 & 1069 & 1379 & 1403 & 1273 & 200 \\
\hline $\mathrm{HF}$ & $\mathrm{lb} / \mathrm{TBtu}$ & $<6000$ & $<6000$ & $<6000$ & $<6000$ & $<6000$ & $<6000$ & $<6000$ & \\
\hline $\mathrm{HBr}$ & $\mathrm{lb} / \mathrm{TB} t u$ & $<600$ & $<600$ & $<600$ & $<600$ & $<600$ & $<600$ & $<600$ & \\
\hline \multicolumn{10}{|l|}{ Metals } \\
\hline $\mathrm{Sb}$ & $\mathrm{lb} / \mathrm{TB} t \mathrm{u}$ & 23 & 22 & 29 & 24 & 26 & 31 & 26 & 3 \\
\hline As & lb/TBtu & 291 & 266 & 440 & 294 & 295 & 257 & 307 & 61 \\
\hline $\mathrm{Be}$ & lb/TBtu & 7 & 13 & 16 & 12 & 11 & 19 & 13 & 4 \\
\hline $\mathrm{Cd}$ & lb/TBtu & 4.9 & 4.7 & 5.3 & 4.6 & 4.1 & 5.0 & 4.8 & 0.4 \\
\hline $\mathrm{Cr}$ & lb/TBtu & 609 & 783 & 728 & 973 & 1050 & 997 & 857 & 160 \\
\hline Co & $\mathrm{lb} / \mathrm{TBtu}$ & 89 & 85 & 104 & 91 & 87 & 96 & 92 & 6 \\
\hline $\mathrm{Pb}$ & lb/TBtu & 143 & 156 & 151 & 126 & 132 & 182 & 148 & 18 \\
\hline $\mathrm{Mn}$ & lb/TBtu & 3912 & 5320 & 3645 & 3015 & 3235 & 2854 & 3663 & 823 \\
\hline $\mathrm{Hg}$ & lb/TBtu & 7.95 & 7.82 & 6.64 & 8.54 & 7.24 & 6.02 & 7.37 & 0.85 \\
\hline $\mathrm{Ni}$ & lb/TBtu & 454 & 383 & 446 & 765 & 672 & 570 & 548 & 135 \\
\hline $\mathrm{Se}$ & lb/TBtu & 50 & 62 & 60 & 46 & 41 & 46 & 51 & 7 \\
\hline
\end{tabular}


Table A-7. Plant 3, Coal Data

\begin{tabular}{|c|c|c|c|c|c|c|c|c|c|}
\hline $\begin{array}{l}\text { Date: } \\
\text { Time: }\end{array}$ & & $\begin{array}{c}10 / 16 / 12 \\
11: 21 \\
\end{array}$ & $\begin{array}{c}10 / 19 / 12 \\
9: 50\end{array}$ & $\begin{array}{c}10 / 19 / 12 \\
17: 39 \\
\end{array}$ & $\begin{array}{c}10 / 20 / 12 \\
12: 05 \\
\end{array}$ & $\begin{array}{c}10 / 21 / 12 \\
8: 31 \\
\end{array}$ & $\begin{array}{c}10 / 21 / 12 \\
15: 30 \\
\end{array}$ & Average & $\begin{array}{c}\text { Standard } \\
\text { Deviation }\end{array}$ \\
\hline \multicolumn{10}{|l|}{ Proximate } \\
\hline $\begin{array}{l}\text { Moisture } \\
\text { Volatile }\end{array}$ & $\%^{a}$ & 37.32 & 37.58 & 36.36 & 37.41 & 37.55 & 37.25 & 37.25 & 0.45 \\
\hline Matter & $\%$ & 24.35 & 23.74 & 23.61 & 23.81 & 24.34 & 24.81 & 24.11 & 0.46 \\
\hline Fixed Carbon & $\%$ & 31.33 & 30.31 & 27.79 & 32.28 & 30.27 & 29.79 & 30.30 & 1.52 \\
\hline Ash & $\%$ & 7.00 & 8.36 & 12.24 & 6.50 & 7.84 & 8.16 & 8.35 & 2.03 \\
\hline \multicolumn{10}{|l|}{ Ultimate } \\
\hline $\mathrm{H}$ & $\%$ & 6.72 & 6.69 & 6.34 & 6.61 & 6.63 & 6.66 & 6.61 & 0.14 \\
\hline $\mathrm{C}$ & $\%$ & 38.87 & 38.04 & 36.66 & 39.00 & 38.23 & 38.30 & 38.18 & 0.84 \\
\hline $\mathrm{N}$ & $\%$ & 0.58 & 0.55 & 0.57 & 0.57 & 0.59 & 0.65 & 0.59 & 0.03 \\
\hline $\mathrm{S}$ & $\%$ & 0.50 & 0.54 & 2.22 & 0.52 & 0.61 & 0.81 & 0.87 & 0.67 \\
\hline $\mathrm{O}$ & $\%$ & 46.32 & 45.82 & 41.97 & 46.79 & 46.11 & 45.42 & 45.41 & 1.74 \\
\hline Heating Value & $\mathrm{Btu} / \mathrm{lb}$ & 6441 & 6236 & 5971 & 6434 & 6292 & 6320 & 6282 & 172 \\
\hline $\mathrm{F}_{\mathrm{d}}$ & $\mathrm{dscf} / 10^{6} \mathrm{Btu}$ & 9835 & 9977 & 10,308 & 9782 & 9886 & 9945 & 9956 & 187 \\
\hline $\mathrm{H}$ & $\%^{b}$ & 2.54 & 2.48 & 2.27 & 2.42 & 2.43 & 2.49 & 2.44 & 0.09 \\
\hline $\mathrm{O}$ & $\%^{\mathrm{b}}$ & 13.18 & 12.45 & 9.68 & 13.57 & 12.76 & 12.34 & 12.33 & 1.38 \\
\hline
\end{tabular}

${ }^{\mathrm{a}}$ As received unless otherwise noted.

${ }^{\mathrm{b}}$ Values not including moisture. 
Table A-8. Plant 3, Coal Halogens and Trace Element Data

\begin{tabular}{llcccccccc}
\hline Date: & & $10 / 16 / 12$ & $10 / 19 / 12$ & $10 / 19 / 12$ & $10 / 20 / 12$ & $10 / 21 / 12$ & $10 / 21 / 12$ \\
$15: 30$ & Average & Standard \\
Deviation
\end{tabular}


Table A-9a. Plant 3, Calculated Uncontrolled Emissions from Coal

\begin{tabular}{|c|c|c|c|c|c|c|c|c|c|}
\hline $\begin{array}{l}\text { Date: } \\
\text { Time: }\end{array}$ & & $\begin{array}{c}10 / 16 / 12 \\
11: 21 \\
\end{array}$ & $\begin{array}{c}10 / 19 / 12 \\
9: 50 \\
\end{array}$ & $\begin{array}{c}10 / 19 / 12 \\
17: 39 \\
\end{array}$ & $\begin{array}{c}10 / 20 / 12 \\
12: 05 \\
\end{array}$ & $\begin{array}{c}10 / 21 / 12 \\
8: 31 \\
\end{array}$ & $\begin{array}{c}10 / 21 / 12 \\
15: 30 \\
\end{array}$ & Average & $\begin{array}{c}\text { Standard } \\
\text { Deviation }\end{array}$ \\
\hline \multicolumn{10}{|c|}{ Halogens } \\
\hline $\mathrm{HCl}$ & ppmv* & 1.68 & 1.48 & 1.33 & 1.24 & 1.42 & 1.41 & 1.43 & 0.15 \\
\hline $\mathrm{HF}$ & ppmv* & $<10$ & $<10$ & $<10$ & $<10$ & $<10$ & $<10$ & $<10$ & \\
\hline $\mathrm{HBr}$ & ppmv* & $<0.3$ & $<0.3$ & $<0.3$ & $<0.3$ & $<0.3$ & $<0.3$ & $<0.3$ & \\
\hline \multicolumn{10}{|c|}{ Metals } \\
\hline $\mathrm{Sb}$ & $\mu \mathrm{g} / \mathrm{dNm}^{3} *$ & 46.2 & 45.5 & 44.0 & 50.5 & 55.1 & 56.2 & 49.6 & 5.2 \\
\hline As & $\mu \mathrm{g} / \mathrm{dNm}^{3 *}$ & 645 & 475 & 972 & 524 & 722 & 706 & 674 & 176 \\
\hline $\mathrm{Be}$ & $\mu \mathrm{g} / \mathrm{dNm}^{3} *$ & 58.3 & 44.1 & 44.0 & 50.7 & 59.8 & 69.4 & 54.4 & 10.0 \\
\hline $\mathrm{Cd}$ & $\mu \mathrm{g} / \mathrm{dNm}^{3 *}$ & 7.5 & 7.4 & 8.2 & 9.7 & 9.6 & 9.6 & 8.7 & 1.1 \\
\hline $\mathrm{Cr}$ & $\mu \mathrm{g} / \mathrm{dNm}^{3 *}$ & 575 & 676 & 1462 & 485 & 651 & 584 & 739 & 361 \\
\hline $\mathrm{Co}$ & $\mu \mathrm{g} / \mathrm{dNm}^{3} *$ & 230 & 256 & 241 & 220 & 245 & 247 & 240 & 13 \\
\hline $\mathrm{Pb}$ & $\mu \mathrm{g} / \mathrm{dNm}^{3} *$ & 538 & 461 & 359 & 504 & 503 & 422 & 465 & 65 \\
\hline $\mathrm{Mn}$ & $\mu \mathrm{g} / \mathrm{dNm}^{3 *}$ & 12,063 & 10,950 & 12,023 & 10,649 & 12,130 & 11,938 & 11,625 & 650 \\
\hline $\mathrm{Hg}$ & $\mu \mathrm{g} / \mathrm{dNm}^{3} *$ & 14.1 & 11.9 & 40.6 & 13.4 & 20.5 & 20.0 & 20.1 & 10.7 \\
\hline $\mathrm{Ni}$ & $\mu \mathrm{g} / \mathrm{dNm}^{3 *}$ & 289 & 256 & 423 & 292 & 313 & 300 & 312 & 57 \\
\hline $\mathrm{Se}$ & $\mu \mathrm{g} / \mathrm{dNm}^{3} *$ & 94 & 96 & 85 & 104 & 81 & 73 & 89 & 11 \\
\hline
\end{tabular}

*At 3\% $\mathrm{O}_{2}$. 
Table A-9a. Plant 3, Calculated Uncontrolled Emissions from Coal

\begin{tabular}{|c|c|c|c|c|c|c|c|c|c|}
\hline Sample ID & & Run 1 & Run 2 & Run 4 & Run 7 & Run 9 & Run 11 & & \\
\hline Date: & & $10 / 16 / 12$ & $10 / 19 / 12$ & $10 / 19 / 12$ & $10 / 20 / 12$ & $10 / 21 / 12$ & $10 / 21 / 12$ & & Standard \\
\hline Time: & & $11: 21$ & $9: 50$ & $17: 39$ & $12: 05$ & $8: 31$ & $15: 30$ & Average & Deviation \\
\hline \multicolumn{10}{|l|}{ Halogens } \\
\hline $\mathrm{HCl}$ & lb/TBtu & 1791 & 1606 & 1491 & 1321 & 1521 & 1521 & 1542 & 154 \\
\hline $\mathrm{HF}$ & lb/TBtu & $<6000$ & $<6000$ & $<6000$ & $<6000$ & $<6000$ & $<6000$ & $<6000$ & \\
\hline $\mathrm{HBr}$ & $\mathrm{lb} / \mathrm{TB} t \mathrm{u}$ & $<600$ & $<600$ & $<600$ & $<600$ & $<600$ & $<600$ & $<600$ & \\
\hline \multicolumn{10}{|l|}{ Metals } \\
\hline $\mathrm{Sb}$ & lb/TBtu & 33 & 33 & 33 & 36 & 40 & 41 & 36 & 4 \\
\hline As & lb/TBtu & 462 & 345 & 730 & 374 & 520 & 511 & 490 & 137 \\
\hline $\mathrm{Be}$ & lb/TBtu & 42 & 32 & 33 & 36 & 43 & 50 & 39 & 7 \\
\hline $\mathrm{Cd}$ & lb/TBtu & 5 & 5 & 6 & 7 & 7 & 7 & 6 & 1 \\
\hline $\mathrm{Cr}$ & lb/TBtu & 412 & 491 & 1098 & 345 & 468 & 423 & 540 & 278 \\
\hline $\mathrm{Co}$ & lb/TBtu & 164 & 186 & 181 & 157 & 177 & 179 & 174 & 11 \\
\hline $\mathrm{Pb}$ & lb/TBtu & 385 & 335 & 270 & 359 & 362 & 306 & 336 & 42 \\
\hline $\mathrm{Mn}$ & lb/TBtu & 8641 & 7958 & 9027 & 7588 & 8734 & 8648 & 8433 & 543 \\
\hline $\mathrm{Hg}$ & lb/TBtu & 10.1 & 8.7 & 30.5 & 9.5 & 14.8 & 14.5 & 14.7 & 8.2 \\
\hline $\mathrm{Ni}$ & lb/TBtu & 207 & 186 & 318 & 208 & 225 & 217 & 227 & 46 \\
\hline $\mathrm{Se}$ & lb/TBtu & 67 & 70 & 64 & 74 & 59 & 53 & 64 & 8 \\
\hline
\end{tabular}




\section{APPENDIX B}

\section{STACK EMISSION MEASUREMENT DATA}

B1 - Halogen Stack Emission Measurement Data

B2 - Metal Stack Emission Measurement Data 
APPENDIX B1

\section{HALOGEN STACK EMISSION MEASUREMENT DATA}


Table B1-1a. Plant 1 EPA Method 26A Halogen Stack Emission, dry ppm(v) at 3\% $\mathbf{O}_{2}$

\begin{tabular}{lrrrrrrrrrrrr}
\hline & M26-1 & M26-2 & M26-3 & M26-4 & M26-5 & M26-6 & M26-7 & M26-8 & M26-9 & Avg. & RSD, ${ }^{\text {a }} \%$ \\
\hline $\mathrm{HCl}$ & 0.29 & 0.30 & 0.30 & 0.19 & 0.15 & 0.20 & 0.24 & 0.22 & 0.22 & 0.23 & 23 \\
$\mathrm{HF}$ & 3.56 & 4.08 & 3.64 & 2.28 & 1.56 & 1.78 & 2.19 & 2.42 & 3.22 & 2.75 & 33 & $<2$ \\
$\mathrm{HBr}$ & $<0.02$ & $<0.02$ & $<0.02$ & $<0.02$ & $<0.02$ & $<0.02$ & $<0.02$ & $<0.02$ & $<0.02$ & $<0.02$ & - & \\
\hline
\end{tabular}

${ }^{\mathrm{a}}$ Relative standard deviation.

Table B1-1b. Plant 1 EPA Method 26A Halogen Stack Emission, lb/TBtu

\begin{tabular}{lcccccrrrrrr}
\hline & M26-1 & M26-2 & M26-3 & M26-4 & M26-5 & M26-6 & M26-7 & M26-8 & M26-9 & Average & RSD ${ }^{\text {a }} \%$ \\
\hline $\mathrm{HCl}$ & 319 & 327 & 323 & 212 & 160 & 214 & 259 & 240 & 234 & 254 & 23 \\
$\mathrm{HF}$ & 2125 & 2435 & 2178 & 1364 & 931 & 1063 & 1310 & 1444 & 1923 & 1642 & 33 \\
$\mathrm{HBr}$ & $<40$ & $<40$ & $<40$ & $<40$ & $<40$ & $<40$ & $<40$ & $<40$ & $<40$ & $<40$ & \\
\hline
\end{tabular}

${ }^{\mathrm{a}}$ Relative standard deviation.

Table B1-1c. Plant 1 ME-ST-H HCl Stack Emissions, dry ppm(v) at 3\% $\mathbf{O}_{2}$

\begin{tabular}{llllllllllll}
\hline & T1 & T2 & T3 & T4 & T5 & T6 & T7 & T8 & T9 & Avg. & RSD ${ }^{\mathrm{a}} \%$ \\
\hline Trap A & 0.393 & 0.291 & 0.179 & 0.161 & 0.125 & 0.146 & 0.208 & 0.239 & 0.391 & & \\
Trap B & 0.331 & 0.274 & 0.252 & 0.169 & 0.158 & 0.701 & 0.215 & 0.165 & 0.421 & \\
RD, ${ }^{\mathrm{b}}$ \% & 8.5 & 3.0 & 17.1 & 2.3 & 11.7 & 65.5 & 1.5 & 18.1 & 3.7 & \\
Combined & 0.362 & 0.283 & 0.216 & 0.165 & 0.141 & - & 0.212 & 0.202 & 0.406 & 0.248 & 38 \\
\hline
\end{tabular}

${ }^{\mathrm{a}}$ Relative standard deviation.

${ }^{\mathrm{b}}$ Relative difference.

Table B1-1d. Plant 1 ME-ST-H Stack Emission, lb/TBtu

\begin{tabular}{cccccccccccc}
\hline & TM-1 & TM-2 & TM-3 & TM-4 & TM-5 & TM-6 & TM-7 & TM-8 & TM-9 & Average & RSD ${ }^{\text {a }} \%$ \\
\hline $\mathrm{HCl}$ & 394 & 308 & 235 & 180 & 154 & 461 & 230 & 220 & 442 & 292 & 39 \\
\hline${ }^{\mathrm{a}}$ Relative standard deviation. & & & & & & & &
\end{tabular}

${ }^{\mathrm{a}}$ Relative standard deviation.

${ }^{\mathrm{b}}$ Relative difference for duplicate trap $>20 \%$. 
Table B1-2a. Plant 2 EPA Method 26A Halogen Stack Emissions, dry ppm(v) at 3\% $\mathrm{O}_{2}$

\begin{tabular}{lcccccccccccc} 
& M26-1 & M26-2 & M26-3 & M26-4 & M26-5 & M26-6 & M26-7 & M26-8 & M26-9 & M26-10 & Avg. & RSD \\
\hline $\mathrm{HCl}$ & 1.79 & 1.38 & 1.28 & 1.29 & 1.27 & 1.30 & 1.35 & 1.32 & 1.28 & 1.32 & 1.36 & 12 \\
$\mathrm{HF}$ & 6.44 & 4.86 & 4.46 & 4.40 & 4.00 & 3.92 & 3.59 & 6.43 & 6.23 & 5.54 & 4.99 & 22 \\
$\mathrm{HBr}$ & 0.02 & 0.03 & 0.03 & 0.03 & 0.02 & 0.02 & 0.03 & 0.03 & 0.02 & 0.03 & 0.03 & 12 \\
\hline${ }^{\mathrm{a}}$ Relative standard deviation
\end{tabular}

${ }^{\mathrm{a}}$ Relative standard deviation.

Table B1-2b. Plant 2 EPA Method 26A Stack Emission, lb/TBtu

\begin{tabular}{lcccccccccccc}
\hline & M26-1 & M26-2 & M26-3 & M26-4 & M26-5 & M26-6 & M26-7 & M26-8 & M26-9 & M26-10 & Average $^{\text {RSD }}$, \% \\
\hline $\mathrm{HCl}$ & 1980 & 1527 & 1415 & 1421 & 1399 & 1432 & 1493 & 1463 & 1412 & 1459 & 1500 & 12 \\
$\mathrm{HF}$ & 3906 & 2949 & 2707 & 2672 & 2428 & 2375 & 2176 & 3897 & 3779 & 3357 & 3025 & 22 \\
$\mathrm{HBr}$ & 55 & 72 & 67 & 70 & 59 & 52 & 70 & 66 & 61 & 78 & 65 & 12 \\
\hline
\end{tabular}

\section{Table B1-2c. Plant 2 ME-ST-H HCI Stack Emission,* dry ppm(v) at 3\% $\mathbf{O}_{2}$}

\begin{tabular}{lclllllllllll}
\hline & T2 & T3 & T4 & T5 & T6 & T7 & T8 & T9 & T10 & T11 & Avg. & RSD ${ }^{\mathrm{a}}, \%$ \\
\hline Trap A & 1.39 & 1.35 & 1.32 & 1.06 & 1.66 & 1.36 & 1.21 & 1.14 & 1.09 & 1.13 & \\
Trap B & 1.08 & 1.11 & 0.87 & 1.27 & 1.42 & 1.52 & 1.14 & 1.12 & 1.20 & 1.01 & \\
RD $^{\mathrm{b}}, \%$ & 12.7 & 9.7 & 20.7 & 8.9 & 7.6 & 5.8 & 3.2 & 0.5 & 5.0 & 5.6 & \\
Combined & 1.23 & 1.23 & & 1.17 & 1.54 & 1.44 & 1.18 & 1.13 & 1.14 & 1.07 & 1.24 & 12 \\
\hline
\end{tabular}

${ }^{a}$ Relative standard deviation.

${ }^{\mathrm{b}}$ Relative difference.

*Run 1 was nonrecoverable as a result of melted fittings because of the hot stack temperature; Run 11 was added to replace the missed run. 
Table B1-2d. Plant 2 ME-ST-H HCl Stack Emission, lb/TBtu

\begin{tabular}{|c|c|c|c|c|c|c|c|c|c|c|c|c|}
\hline & TM-2 & TM-3 & TM-4 & TM-5 & TM-6 & TM-7 & TM-8 & TM-9 & TM-10 & TM-11 & Average & $\mathrm{RSD}^{\mathrm{d}}{ }^{\mathrm{d}} \%$ \\
\hline $\mathrm{HCl}$ & 1364 & 1358 & $1208^{\mathrm{d}}$ & 1292 & 1702 & 1592 & 1299 & 1249 & 1262 & 1185 & 1351 & 12 \\
\hline
\end{tabular}

Table B1-3a. Plant 3 EPA Method 26A Halogen Stack Emissions, dry ppm(v) at 3\% $\mathbf{O}_{\mathbf{2}}$

\begin{tabular}{lccccccccccccc}
\hline & M26-1 & M26-2 & M26-3 & M26-4 & M26-5 & M26-6 & M26-7 & M26-8 & M26-11* & Avg. & RSD ${ }^{\text {a } \%}$ \\
\hline $\mathrm{HCl}$ & $<0.04$ & $<0.04$ & $<0.04$ & $<0.04$ & $<0.04$ & $<0.04$ & $<0.04$ & $<0.04$ & $<0.04$ & $<0.04$ & - \\
$\mathrm{HF}$ & $<0.01$ & $<0.01$ & $<0.01$ & $<0.01$ & $<0.01$ & $<0.01$ & $<0.01$ & $<0.01$ & $<0.01$ & $<0.01$ & - \\
$\mathrm{HBr}$ & 0.035 & 0.044 & 0.043 & 0.069 & 0.046 & 0.037 & 0.036 & 0.043 & 0.048 & 0.045 & 23 & \\
\hline
\end{tabular}

${ }^{\mathrm{a}}$ Relative standard deviation.

*Run 11 was completed after Runs 9 and 10, which were not part of this project, because of unit operations.

Table B1-3b. Plant 3 EPA Method 26 A Halogen Stack Emission, lb/TBtu

\begin{tabular}{lccccccccccr}
\hline & M26-1 & M26-2 & M26-3 & M26-4 & M26-5 & M26-6 & M26-7 & M26-8 & M26-11 & Average & RSD ${ }^{\mathrm{a}} \%$ \\
\hline $\mathrm{HCl}$ & 7 & 8 & 9 & 9 & 8 & 7 & 8 & 7 & 7 & 8 & 12 \\
$\mathrm{HF}$ & 4 & 4 & 6 & 4 & 5 & $<6$ & $<6$ & $<6$ & $<6$ & 4 & 15 \\
$\mathrm{HBr}$ & 84 & 106 & 104 & 166 & 109 & 88 & 85 & 102 & 116 & 107 & 23 \\
\hline
\end{tabular}

${ }^{\mathrm{a}}$ Relative standard deviation.

Table B1-3c. Plant 3 ME-ST-H HCl Stack Emission, dry ppm(v) at 3\% $\mathbf{O}_{2}$

\begin{tabular}{lccccccccccc}
\hline & T1 & T2 & T3 & T4 & T5 & T6 & T7 & T8 & T11* & Avg. & RSD ${ }^{\mathrm{a}}, \%$ \\
\hline Trap A & 0.30 & 0.27 & 0.34 & 0.24 & 0.26 & 0.21 & 0.25 & 0.25 & 0.26 & & \\
Trap B & 0.20 & 0.22 & 0.13 & 0.32 & 0.29 & 0.32 & 0.22 & 0.29 & 0.30 & \\
RD $^{\text {b }, \%}$ & 19.2 & 10.6 & 43.5 & 13.1 & 5.0 & 20.5 & 4.8 & 7.9 & 7.2 & 0.26 & 6.7 \\
\hline${ }^{\mathrm{a}}$ Re & & & & & & & &
\end{tabular}

${ }^{\mathrm{a}}$ Relative standard deviation.

${ }^{\mathrm{b}}$ Relative difference.

*Run 11 was completed after Runs 9 and 10, which were not part of this project, because of unit operations. 
Table B1-3d. Plant 3 ME-ST-H HCI Stack Emission, lb/TBtu

\begin{tabular}{|c|c|c|c|c|c|c|c|c|c|c|c|}
\hline & TM-1 & TM-2 & TM-3 & TM-4 & TM-5 & TM-6 & TM-7 & TM-8 & TM-11 & Average & $\mathrm{RSD}, \%$ \\
\hline $\mathrm{HCl}$ & 273 & 264 & $253^{d}$ & 302 & 294 & $288^{d}$ & 255 & 288 & 298 & 279 & 7 \\
\hline
\end{tabular}

${ }^{\mathrm{a}}$ Relative standard deviation.

${ }^{\mathrm{d}}$ Relative difference for duplicate traps $>20 \%$. 


\section{APPENDIX B2}

\section{METAL STACK EMISSION MEASUREMENT DATA}


Table B2-1a. Plant 1 Estimated Metal Capture

\begin{tabular}{lcccccccccccc}
\hline & & $\mathrm{Sb}$ & $\mathrm{As}$ & $\mathrm{Be}$ & $\mathrm{Cd}$ & $\mathrm{Cr}$ & $\mathrm{Co}$ & $\mathrm{Pb}$ & $\mathrm{Mn}$ & $\mathrm{Hg}$ & $\mathrm{Ni}$ & $\mathrm{Se}$ \\
\hline MATS & lb/TBtu & 0.8 & 1.1 & 0.2 & 0.3 & 2.8 & 0.8 & 1.2 & 4.0 & 4.0 & 3.5 & 5.0 \\
Coal & $\mathrm{lb} /$ TBtu & 88 & 1315 & 73 & 16.2 & 1759 & 256 & 519 & 7871 & 11.0 & 1436 & 66.7 \\
M29 & $1 \mathrm{~b} /$ TBtu & $<1$ & $<0.4$ & $<0.1$ & $<0.1$ & $1.8^{\mathrm{b}}$ & $<0.3$ & $1.0^{\mathrm{b}}$ & $1.8^{\mathrm{b}}$ & 8.33 & $1.4^{\mathrm{b}}$ & $3.0^{\mathrm{b}}$ \\
Capture & $\%$ & $>98$ & $>99$ & $>99$ & $>99$ & 99.9 & $>99$ & 99.8 & 100 & 24.1 & 99.9 & 95.5 \\
ME-ST & $1 \mathrm{~b} /$ TBtu & $<0.04^{\mathrm{c}}$ & $<0.2^{\mathrm{c}}$ & $<0.04^{\mathrm{c}}$ & $0.69^{\mathrm{b}, \mathrm{d}}$ & $0.66^{\mathrm{b}, \mathrm{d}}$ & $<0.2^{\mathrm{c}}$ & $6.8^{\mathrm{b}, \mathrm{d}}$ & $9.4^{\mathrm{b}, \mathrm{d}}$ & 6.82 & $2.1^{\mathrm{b}, \mathrm{d}}$ & 2.15 \\
Capture & $\%$ & $>99$ & $>99$ & $>99$ & 95.7 & 100 & $>99$ & 98.7 & 99.9 & 37.8 & 99.9 & 96.8 \\
\hline
\end{tabular}

${ }^{\mathrm{a}}$ Blank corrected (blank) $>10 \%$ of sample value.

${ }^{\mathrm{b}}$ Blank $>30 \%$ of sample value.

${ }^{\mathrm{c}}$ Blank corrected to below deviation limit.

${ }^{\mathrm{d}}$ Relative difference for duplicate trap $>20 \%$.

Table B2-1b. Plant 1 EPA Method 29 Metal Stack Emission, lb/TBtu

\begin{tabular}{|c|c|c|c|c|c|c|c|c|c|c|c|}
\hline & $\mathrm{Sb}$ & As & $\mathrm{Be}$ & $\mathrm{Cd}$ & $\mathrm{Cr}$ & $\mathrm{Co}$ & $\mathrm{Pb}$ & $\mathrm{Mn}$ & $\mathrm{Hg}$ & $\mathrm{Ni}$ & $\mathrm{Se}$ \\
\hline M29-1 & $<2$ & $<0.5$ & $<0.2$ & $<0.2$ & $1.2^{\mathrm{b}}$ & $<0.3$ & $1.9^{\mathrm{a}}$ & $4.1^{\mathrm{a}}$ & 8.34 & $1.7^{\mathrm{b}}$ & $2.3^{\mathrm{b}}$ \\
\hline M29-2 & $<1$ & $<0.3$ & $<0.1$ & $<0.1$ & $1.5^{\mathrm{b}}$ & $<0.3$ & $0.3^{b}$ & $0.7^{\mathrm{b}}$ & 8.86 & $0.33^{b}$ & $1.9^{\mathrm{b}}$ \\
\hline M29-3 & $<1$ & $<0.4$ & $<0.1$ & $<0.1$ & $1.7^{\mathrm{b}}$ & $<0.3$ & $1.0^{\mathrm{b}}$ & $2.0^{\mathrm{b}}$ & 8.61 & $0.44^{\mathrm{b}}$ & $4.3^{\mathrm{b}}$ \\
\hline M29-4 & $<1$ & $<0.3$ & $<0.1$ & $<0.2$ & $1.3^{\mathrm{b}}$ & $<0.3$ & $0.6^{\mathrm{b}}$ & $1.6^{\mathrm{b}}$ & 9.28 & $0.37^{b}$ & $5.1^{\mathrm{a}}$ \\
\hline M29-5 & $<1$ & $<0.3$ & $<0.1$ & $<0.1$ & $3.6^{\mathrm{b}}$ & $<0.4$ & $1.1^{\mathrm{b}}$ & $1.6^{\mathrm{b}}$ & 7.67 & $4.8^{\mathrm{b}}$ & $3.7^{\mathrm{b}}$ \\
\hline M29-6 & $<1$ & $<0.3$ & $<0.1$ & $<0.1$ & $1.2^{\mathrm{b}}$ & $<0.3$ & $0.7^{\mathrm{b}}$ & $1.9^{\mathrm{b}}$ & 7.62 & $1.5^{\mathrm{b}}$ & $2.7^{\mathrm{b}}$ \\
\hline M29-7 & $<1$ & $<0.4$ & $<0.1$ & $<0.1$ & $2.0^{\mathrm{b}}$ & $<0.3$ & $1.2^{\mathrm{b}}$ & $1.3^{\mathrm{b}}$ & 7.57 & $0.8^{\mathrm{b}}$ & $1.8^{\mathrm{b}}$ \\
\hline M29-8 & $<1$ & $<0.4$ & $<0.1$ & $<0.1$ & $2.2^{\mathrm{b}}$ & $<0.3$ & $0.6^{\mathrm{b}}$ & $1.2^{\mathrm{b}}$ & 8.46 & $2.0^{\mathrm{b}}$ & $2.1^{\mathrm{b}}$ \\
\hline M29-9 & $<1$ & $<0.4$ & $<0.1$ & $<0.1$ & $1.4^{\mathrm{b}}$ & $<0.3$ & $1.3^{\mathrm{a}}$ & $1.4^{\mathrm{b}}$ & 8.58 & $0.53^{b}$ & $2.9^{\mathrm{b}}$ \\
\hline Average & $<1$ & $<0.4$ & $<0.1$ & $<0.1$ & $1.8^{\mathrm{b}}$ & $<0.3$ & $1.0^{\mathrm{b}}$ & $1.8^{\mathrm{b}}$ & 8.33 & $1.4^{\mathrm{b}}$ & $3.0^{\mathrm{b}}$ \\
\hline Std. Dev. & & & & & 0.8 & & 0.5 & 1.0 & 0.60 & 1.4 & 1.2 \\
\hline RSD* & & & & & 42 & & 49 & 55 & 7 & 103 & 39 \\
\hline
\end{tabular}

* Relative standard deviation, $\%$.

${ }^{\text {a }}$ Blank corrected (blank) $>10 \%$ of sample value.

${ }^{\mathrm{b}}$ Blank $>30 \%$ of sample value.

${ }^{c}$ Blank corrected to below deviation limit.

${ }^{\mathrm{d}}$ Relative difference for duplicate trap $>20 \%$. 
Table B2-1c. Plant 1 EPA Method 29 metal Stack Emission, $\mu \mathrm{gg} / \mathrm{dNm}^{3}$ at $3 \% \mathrm{O}_{2}$

\begin{tabular}{|c|c|c|c|c|c|c|c|c|c|c|c|}
\hline & $\mathrm{Sb}$ & As & $\mathrm{Be}$ & $\mathrm{Cd}$ & $\mathrm{Cr}$ & $\mathrm{Co}$ & $\mathrm{Pb}$ & $\mathrm{Mn}$ & $\mathrm{Hg}$ & $\mathrm{Ni}$ & $\mathrm{Se}$ \\
\hline M29-1 & $<2$ & $<0.6$ & $<0.2$ & $<0.2$ & $1.7^{\mathrm{b}}$ & $<0.5$ & $2.6^{\mathrm{a}}$ & $5.6^{\mathrm{a}}$ & 11.4 & $2.3^{\mathrm{b}}$ & $3^{b}$ \\
\hline M29-2 & $<2$ & $<0.4$ & $<0.2$ & $<0.2$ & $2.0^{\mathrm{b}}$ & $<0.4$ & $0.4^{\mathrm{b}}$ & $0.9^{\mathrm{b}}$ & 12.1 & $0.46^{\mathrm{b}}$ & $3^{b}$ \\
\hline M29-3 & $<2$ & $<0.6$ & $<0.2$ & $<0.2$ & $2.3^{\mathrm{b}}$ & $<0.4$ & $1^{\mathrm{b}}$ & $3^{b}$ & 11.8 & $0.60^{\mathrm{b}}$ & $6^{\mathrm{b}}$ \\
\hline M29-4 & $<2$ & $<0.4$ & $<0.2$ & $<0.2$ & $1.8^{\mathrm{b}}$ & $<0.4$ & $0.8^{\mathrm{b}}$ & $2^{b}$ & 12.7 & $0.50^{\mathrm{b}}$ & $7.0^{\mathrm{a}}$ \\
\hline M29-5 & $<2$ & $<0.4$ & $<0.2$ & $<0.2$ & $4.9^{b}$ & $<0.5$ & $2^{b}$ & $2^{b}$ & 10.5 & $6.6^{\mathrm{b}}$ & $5^{\mathrm{b}}$ \\
\hline M29-6 & $<2$ & $<0.4$ & $<0.2$ & $<0.2$ & $1.7^{\mathrm{b}}$ & $<0.4$ & $1^{\mathrm{b}}$ & $3^{b}$ & 10.4 & $2.0^{\mathrm{b}}$ & $4^{b}$ \\
\hline M29-7 & $<2$ & $<0.6$ & $<0.2$ & $<0.2$ & $2.7^{\mathrm{b}}$ & $<0.4$ & $2^{b}$ & $2^{b}$ & 10.4 & $1.1^{\mathrm{b}}$ & $2^{b}$ \\
\hline M29-8 & $<2$ & $<0.6$ & $<0.2$ & $<0.2$ & $3.0^{\mathrm{b}}$ & $<0.4$ & $0.8^{\mathrm{b}}$ & $2^{b}$ & 11.6 & $2.7^{\mathrm{b}}$ & $3^{b}$ \\
\hline M29-9 & $<2$ & $<0.5$ & $<0.2$ & $<0.2$ & $2.0^{\mathrm{b}}$ & $<0.4$ & $1.8^{\mathrm{a}}$ & $2^{b}$ & 11.7 & $0.72^{b}$ & $4^{b}$ \\
\hline Average & $<2$ & $<0.5$ & $<0.2$ & $<0.2$ & $2.5^{\mathrm{b}}$ & $<0.4$ & $1^{\mathrm{b}}$ & $2^{b}$ & 11.4 & $1.9^{\mathrm{b}}$ & $4^{b}$ \\
\hline Std. Dev. & & & & & 1.0 & & 0.7 & 1.3 & 0.8 & 2.0 & 1.6 \\
\hline RSD* & & & & & 42 & & 49 & 55 & 7 & 103 & 39 \\
\hline
\end{tabular}

* Relative standard deviation, $\%$

${ }^{\text {a }}$ Blank corrected (blank) $>10 \%$ of sample value.

${ }^{\mathrm{b}}$ Blank $>30 \%$ of sample value.

${ }^{\mathrm{c}}$ Blank corrected to below deviation limit.

${ }^{\mathrm{d}}$ Relative difference for duplicate trap $>20 \%$. 
Table B2-1d. Plant 1 ME-ST-M Metal Stack Emission, lb/TBtu

\begin{tabular}{|c|c|c|c|c|c|c|c|c|c|c|c|}
\hline & $\mathrm{Sb}$ & As & $\mathrm{Be}$ & $\mathrm{Cd}$ & $\mathrm{Cr}$ & $\mathrm{Co}$ & $\mathrm{Pb}$ & $\mathrm{Mn}$ & $\mathrm{Hg}$ & $\mathrm{Ni}$ & $\mathrm{Se}$ \\
\hline TM-1 & $<0.04^{\mathrm{c}}$ & $<0.2^{\mathrm{c}}$ & $<0.04^{\mathrm{c}}$ & $<0.04^{\mathrm{c}}$ & $0.93^{\mathrm{b}, \mathrm{d}}$ & $0.54^{\mathrm{b}, \mathrm{d}}$ & $<0.04^{\mathrm{c}}$ & $47^{\mathrm{b}}$ & 6.68 & $<0.08^{\mathrm{c}}$ & 1.51 \\
\hline TM-2 & $<0.04^{\mathrm{c}}$ & $<0.2^{\mathrm{c}}$ & $<0.04^{\mathrm{c}}$ & $<0.04^{\mathrm{c}}$ & $<0.04^{\mathrm{c}}$ & $<0.2^{\mathrm{c}}$ & $1.2^{\mathrm{b}, \mathrm{d}}$ & $4.9^{\mathrm{b}, \mathrm{d}}$ & 7.55 & $7.3^{\mathrm{b}, \mathrm{d}}$ & 2.55 \\
\hline TM-3 & $<0.04^{\mathrm{c}}$ & $<0.2^{\mathrm{c}}$ & $0.04^{b}$ & $0.20^{\mathrm{b}, \mathrm{d}}$ & $0.49^{\mathrm{b}, \mathrm{d}}$ & $<0.2^{\mathrm{c}}$ & $1.0^{\mathrm{b}, \mathrm{d}}$ & $5.4^{\mathrm{b}}$ & 7.06 & $3.3^{\mathrm{b}, \mathrm{d}}$ & 2.35 \\
\hline TM-4 & $<0.04^{\mathrm{c}}$ & $<0.2^{\mathrm{c}}$ & $0.05^{\mathrm{b}, \mathrm{d}}$ & $0.82^{\mathrm{b}}$ & $<0.04^{\mathrm{c}}$ & $<0.2^{\mathrm{c}}$ & $9.1^{\mathrm{b}}$ & $9.6^{\mathrm{b}, \mathrm{d}}$ & 7.28 & $3.5^{\mathrm{b}, \mathrm{d}}$ & 3.97 \\
\hline TM-5 & $<0.04^{\mathrm{c}}$ & $<0.2^{\mathrm{c}}$ & $<0.04^{\mathrm{c}}$ & $0.16^{\mathrm{b}, \mathrm{d}}$ & $<0.04^{\mathrm{c}}$ & $<0.2^{\mathrm{c}}$ & $1.8^{\mathrm{b}, \mathrm{d}}$ & $1.8^{\mathrm{b}, \mathrm{d}}$ & 6.48 & $<0.07^{\mathrm{c}}$ & $2.67^{\mathrm{d}}$ \\
\hline TM-6 & $<0.04^{\mathrm{c}}$ & $<0.2^{\mathrm{c}}$ & $<0.04^{\mathrm{c}}$ & $1.3^{\mathrm{b}, \mathrm{d}}$ & $2.8^{\mathrm{b}}$ & $<0.2^{\mathrm{c}}$ & $12^{\mathrm{b}, \mathrm{d}}$ & $10^{\mathrm{b}}$ & 6.60 & $<0.07^{\mathrm{c}}$ & 1.95 \\
\hline TM-7 & $<0.04^{\mathrm{c}}$ & $<0.2^{\mathrm{c}}$ & $<0.04^{\mathrm{c}}$ & $0.32^{b, d}$ & $1.2^{\mathrm{b}, \mathrm{d}}$ & $<0.2^{\mathrm{c}}$ & $2.6^{\mathrm{b}, \mathrm{d}}$ & $<0.04^{\mathrm{c}}$ & 6.41 & $<0.07^{\mathrm{c}}$ & 1.07 \\
\hline TM-8 & $<0.03^{\mathrm{c}}$ & $<0.2^{\mathrm{c}}$ & $<0.03^{\mathrm{c}}$ & $2.1^{\mathrm{b}, \mathrm{d}}$ & $<0.03^{\mathrm{c}}$ & $<0.2^{\mathrm{c}}$ & $22^{\mathrm{b}, \mathrm{d}}$ & $2.6^{\mathrm{b}, \mathrm{d}}$ & 6.35 & $<0.07^{\mathrm{c}}$ & 1.19 \\
\hline TM-9 & $<0.04^{\mathrm{c}}$ & $<0.2^{\mathrm{c}}$ & $<0.04^{\mathrm{c}}$ & $1.2^{\mathrm{b}, \mathrm{d}}$ & $0.44^{\mathrm{b}, \mathrm{d}}$ & $<0.2^{\mathrm{c}}$ & $12^{\mathrm{b}, \mathrm{d}}$ & $2.9^{\mathrm{b}, \mathrm{d}}$ & 6.96 & $4.8^{\mathrm{b}, \mathrm{d}}$ & 2.11 \\
\hline Average & $<0.04^{\mathrm{c}}$ & $<0.2^{\mathrm{c}}$ & $<0.04^{\mathrm{c}}$ & $0.69^{b, d}$ & $0.66^{\mathrm{b}, \mathrm{d}}$ & $<0.2^{\mathrm{c}}$ & $6.8^{\mathrm{b}, \mathrm{d}}$ & $9.4^{\mathrm{b}, \mathrm{d}}$ & 6.82 & $2.1^{\mathrm{b}, \mathrm{d}}$ & 2.15 \\
\hline Std. Dev. & & & & 0.73 & 0.91 & & 7.35 & 14.6 & 0.42 & 2.7 & 0.89 \\
\hline RSD* & & & & 106 & 137 & & 108 & 155 & 6 & 126 & 41 \\
\hline
\end{tabular}

* Relative standard deviation, $\%$

${ }^{a}$ Blank corrected (blank) $>10 \%$ of sample value.

${ }^{\mathrm{b}}$ Blank $>30 \%$ of sample value.

${ }^{\mathrm{c}}$ Blank corrected to below deviation limit.

${ }^{\mathrm{d}}$ Relative difference for duplicate trap $>20 \%$. 
Table B2-1e. Plant 1 ME-ST-M Metal Stack Emission, $\mu \mathrm{g} / \mathrm{dNm}^{3}$ at $3 \% \mathrm{O}_{2}$

\begin{tabular}{lccccccccccc}
\hline & $\mathrm{Sb}$ & $\mathrm{As}$ & $\mathrm{Be}$ & $\mathrm{Cd}$ & $\mathrm{Cr}$ & $\mathrm{Co}$ & $\mathrm{Pb}$ & $\mathrm{Mn}$ & $\mathrm{Hg}$ & $\mathrm{Ni}$ & $\mathrm{Se}$ \\
\hline TM-1 & $<0.05^{\mathrm{c}}$ & $<0.3^{\mathrm{c}}$ & $<0.05^{\mathrm{c}}$ & $<0.05^{\mathrm{c}}$ & $1.3^{\mathrm{b}, \mathrm{d}}$ & $0.73^{\mathrm{b}, \mathrm{d}}$ & $<0.05^{\mathrm{c}}$ & $65^{\mathrm{b}}$ & 9.14 & $<0.1^{\mathrm{c}}$ & 2.06 \\
TM-2 & $<0.05^{\mathrm{c}}$ & $<0.3^{\mathrm{c}}$ & $<0.05^{\mathrm{c}}$ & $<0.05^{\mathrm{c}}$ & $<0.05^{\mathrm{c}}$ & $<0.3^{\mathrm{c}}$ & $1.6^{\mathrm{b}, \mathrm{d}}$ & $6.7^{\mathrm{b}, \mathrm{d}}$ & 10.3 & $9.9^{\mathrm{b}, \mathrm{d}}$ & 3.49 \\
TM-3 & $<0.05^{\mathrm{c}}$ & $<0.3^{\mathrm{c}}$ & $0.05^{\mathrm{b}}$ & $0.28^{\mathrm{b}, \mathrm{d}}$ & $0.67^{\mathrm{b}, \mathrm{d}}$ & $<0.3^{\mathrm{c}}$ & $1.4^{\mathrm{b}, \mathrm{d}}$ & $7.3^{\mathrm{b}}$ & 9.67 & $4.5^{\mathrm{b}, \mathrm{d}}$ & 3.21 \\
TM-4 & $<0.05^{\mathrm{c}}$ & $<0.2^{\mathrm{c}}$ & $0.07^{\mathrm{b}, \mathrm{d}}$ & $1.1^{\mathrm{b}}$ & $<0.05^{\mathrm{c}}$ & $<0.2^{\mathrm{c}}$ & $13^{\mathrm{b}}$ & $13^{\mathrm{b}, \mathrm{d}}$ & 9.96 & $4.8^{\mathrm{b}, \mathrm{d}}$ & 5.44 \\
TM-5 & $<0.05^{\mathrm{c}}$ & $<0.2^{\mathrm{c}}$ & $<0.05^{\mathrm{c}}$ & $0.23^{\mathrm{b}, \mathrm{d}}$ & $<0.05^{\mathrm{c}}$ & $<0.2^{\mathrm{c}}$ & $2.5^{\mathrm{b}, \mathrm{d}}$ & $2.4^{\mathrm{b}, \mathrm{d}}$ & 8.86 & $<0.1^{\mathrm{c}}$ & $3.66^{\mathrm{d}}$ \\
TM-6 & $<0.05^{\mathrm{c}}$ & $<0.2^{\mathrm{c}}$ & $<0.05^{\mathrm{c}}$ & $1.8^{\mathrm{b}, \mathrm{d}}$ & $3.9^{\mathrm{b}}$ & $<0.2^{\mathrm{c}}$ & $16^{\mathrm{b}, \mathrm{d}}$ & $14^{\mathrm{b}}$ & 9.04 & $<0.1^{\mathrm{c}}$ & 2.67 \\
TM-7 & $<0.05^{\mathrm{c}}$ & $<0.2^{\mathrm{c}}$ & $<0.05^{\mathrm{c}}$ & $0.43^{\mathrm{b}, \mathrm{d}}$ & $1.6^{\mathrm{b}, \mathrm{d}}$ & $<0.2^{\mathrm{c}}$ & $3.5^{\mathrm{b}, \mathrm{d}}$ & $<0.05^{\mathrm{c}}$ & 8.78 & $<0.1^{\mathrm{c}}$ & 1.46 \\
TM-8 & $<0.05^{\mathrm{c}}$ & $<0.2^{\mathrm{c}}$ & $<0.05^{\mathrm{c}}$ & $2.9^{\mathrm{b}, \mathrm{d}}$ & $<0.05^{\mathrm{c}}$ & $<0.2^{\mathrm{c}}$ & $30^{\mathrm{b}, \mathrm{d}}$ & $3.5^{\mathrm{b}, \mathrm{d}}$ & 8.69 & $<0.1^{\mathrm{c}}$ & 1.62 \\
TM-9 & $<0.05^{\mathrm{c}}$ & $<0.2^{\mathrm{c}}$ & $<0.05^{\mathrm{c}}$ & $1.6^{\mathrm{b}, \mathrm{d}}$ & $0.61^{\mathrm{b}, \mathrm{d}}$ & $<0.2^{\mathrm{c}}$ & $17^{\mathrm{b}, \mathrm{d}}$ & $3.9^{\mathrm{b}, \mathrm{d}}$ & 9.52 & $6.6^{\mathrm{b}, \mathrm{d}}$ & 2.89 \\
Average & $<0.05^{\mathrm{c}}$ & $<0.2^{\mathrm{c}}$ & $<0.05^{\mathrm{c}}$ & $0.94^{\mathrm{b}, \mathrm{d}}$ & $0.91^{\mathrm{b}, \mathrm{d}}$ & $<0.3^{\mathrm{c}}$ & $9.3^{\mathrm{b}, \mathrm{d}}$ & $13^{\mathrm{b}, \mathrm{d}}$ & 9.33 & $2.9^{\mathrm{b}, \mathrm{d}}$ & 2.95 \\
Std. Dev. & & & & 1.0 & 1.2 & & 10.1 & 20 & 0.57 & 3.7 & 1.2 \\
RSD* & & & & 106 & 137 & & 108 & 155 & 6 & 126 & 41 \\
\hline
\end{tabular}

* Relative standard deviation, \%

${ }^{\text {a }}$ Blank corrected (blank) $>10 \%$ of sample value.

$\begin{array}{ll}\mathbb{N}_{1} & { }^{\mathrm{a}} \text { Blank corrected (blank) }>10 \% \\ & { }^{\mathrm{b}} \text { Blank }>30 \% \text { of sample value. }\end{array}$

${ }^{\mathrm{c}}$ Blank corrected to below deviation limit.

${ }^{\mathrm{d}}$ Relative difference for duplicate trap $>20 \%$. 
Table B2-2a. Plant 2 Estimated Metals Capture

\begin{tabular}{lcccccccccccc}
\hline & $\mathrm{Sb}$ & $\mathrm{As}$ & $\mathrm{Be}$ & $\mathrm{Cd}$ & $\mathrm{Cr}$ & $\mathrm{Co}$ & $\mathrm{Pb}$ & $\mathrm{Mn}$ & $\mathrm{Hg}$ & $\mathrm{Ni}$ & $\mathrm{Se}$ \\
\hline MATS & 0.8 & 1.1 & 0.2 & 0.3 & 2.8 & 0.8 & 1.2 & 4.0 & 4.0 & 3.5 & 5.0 \\
Coal & 26 & 307 & 13 & 4.8 & 857 & 92 & 148 & 3663 & 7.37 & 548 & 51 \\
M29 & $<1$ & 8.0 & $<0.2$ & $<0.2$ & $3.2^{\mathrm{b}}$ & 0.38 & 4.51 & $13^{\mathrm{b}}$ & 6.03 & $2.1^{\mathrm{b}}$ & 17.9 \\
Capture & $>95$ & 97.4 & $>99$ & $>96$ & 99.6 & 99.5 & 97.0 & 99.6 & 18.2 & 99.6 & 64.8 \\
ME-ST & 0.43 & 6.29 & $0.08^{\mathrm{b}}$ & $0.46^{\mathrm{b}}$ & $4.26^{\mathrm{b}}$ & 0.39 & $11.5^{\mathrm{b}}$ & $6.9^{\mathrm{b}}$ & 6.60 & $2.98^{\mathrm{b}}$ & 6.07 \\
Capture & $>98$ & 98.0 & 99.4 & 90.5 & 99.5 & 99.6 & 92.2 & 99.8 & 10.5 & 99.5 & 88.0 \\
\hline
\end{tabular}

${ }^{\mathrm{a}}$ Blank corrected (blank) $>10 \%$ of sample value.

${ }^{\mathrm{b}}$ Blank $>30 \%$ of sample value.

${ }^{\mathrm{c}}$ Blank corrected to below deviation limit.

${ }^{\mathrm{d}}$ relative difference for duplicate trap $>20 \%$.

Table B2-2b. Plant 2 EPA Method 29 Metal Stack Emission, lb/TBtu

\begin{tabular}{|c|c|c|c|c|c|c|c|c|c|c|c|}
\hline & $\mathrm{Sb}$ & As & $\mathrm{Be}$ & $\mathrm{Cd}$ & $\mathrm{Cr}$ & $\mathrm{Co}$ & $\mathrm{Pb}$ & $\mathrm{Mn}$ & $\mathrm{Hg}$ & $\mathrm{Ni}$ & $\mathrm{Se}$ \\
\hline M29-1 & $<1$ & 6.4 & $<0.2$ & $<0.1$ & $3.26^{\mathrm{a}}$ & 0.33 & 3.30 & $13^{b}$ & 4.89 & $2.9^{b}$ & 25.7 \\
\hline M29-2 & $<1$ & 6.7 & $<0.2$ & $<0.2$ & $3.61^{\mathrm{a}}$ & 0.30 & 2.95 & $11^{b}$ & 6.49 & $2.1^{b}$ & 39.1 \\
\hline M29-3 & $<1$ & 5.6 & $<0.2$ & $<0.2$ & $5.8^{b}$ & 1.03 & 3.39 & $13^{b}$ & 6.65 & $2.8^{b}$ & 12.1 \\
\hline M29-4 & $<1$ & 8.8 & $<0.2$ & 0.3 & $2.6^{\mathrm{b}}$ & 0.40 & 3.42 & $14^{b}$ & 6.80 & $1.7^{\mathrm{b}}$ & 4.63 \\
\hline M29-5 & $<1$ & 9.5 & $<0.2$ & $<0.2$ & $4.2^{b}$ & 0.49 & 9.74 & $16^{\mathrm{b}}$ & 6.88 & $2.9^{b}$ & 18.5 \\
\hline M29-6 & $<1$ & 7.8 & $<0.2$ & $<0.2$ & $1.9^{\mathrm{b}}$ & 0.32 & 2.49 & $14^{\mathrm{b}}$ & 6.33 & $1.9^{\mathrm{b}}$ & 10.3 \\
\hline M29-7 & $<1$ & 7.8 & $<0.2$ & $<0.2$ & $2.5^{\mathrm{b}}$ & 0.43 & 3.99 & $12^{b}$ & 6.34 & $1.6^{\mathrm{b}}$ & 10.3 \\
\hline M29-8 & $<1$ & 8.8 & $<0.2$ & $<0.2$ & $2.5^{b}$ & 0.38 & 5.95 & $13^{b}$ & 5.58 & $1.4^{\mathrm{b}}$ & 30.3 \\
\hline M29-9 & $<1$ & 9.5 & $<0.2$ & $<0.2$ & $3.3^{\mathrm{b}}$ & 0.47 & 5.69 & $12^{\mathrm{b}}$ & 4.95 & $1.6^{\mathrm{b}}$ & 15.3 \\
\hline M29-10 & $<1$ & 8.8 & $<0.2$ & $<0.2$ & $2.8^{\mathrm{b}}$ & 0.35 & 4.20 & $13^{b}$ & 5.36 & $1.5^{\mathrm{b}}$ & 12.6 \\
\hline Average & $<1$ & 8.0 & $<0.2$ & $<0.2$ & $3.2^{\mathrm{b}}$ & 0.45 & 4.51 & $13^{b}$ & 6.03 & $2.1^{b}$ & 17.9 \\
\hline Std. Dev. & & 1.3 & & & 1.1 & 0.21 & 2.15 & 1 & 0.76 & 0.6 & 10.7 \\
\hline RSD* & & 17 & & & 34 & 48 & 48 & 11 & 13 & 29 & 60 \\
\hline
\end{tabular}

* Relative standard deviation, $\%$.

${ }^{\text {a }}$ Blank corrected (blank) $>10 \%$ of sample value.

${ }^{\mathrm{b}}$ Blank $>30 \%$ of sample value.

${ }^{\mathrm{c}}$ Blank corrected to below deviation limit.

${ }^{\mathrm{d}}$ Relative difference for duplicate trap $>20 \%$. 
Table B2-2c. Plant 2 EPA Method 29 Metal Stack Emission, $\mu$ g/dNm ${ }^{3}$ at $3 \% \mathrm{O}_{2}$

\begin{tabular}{|c|c|c|c|c|c|c|c|c|c|c|c|}
\hline & $\mathrm{Sb}$ & As & $\mathrm{Be}$ & $\mathrm{Cd}$ & $\mathrm{Cr}$ & $\mathrm{Co}$ & $\mathrm{Pb}$ & $\mathrm{Mn}$ & $\mathrm{Hg}$ & $\mathrm{Ni}$ & $\mathrm{Se}$ \\
\hline M29-1 & $<1$ & 8.6 & $<0.2$ & $<0.2$ & $4.40^{\mathrm{a}}$ & 0.45 & 4.44 & $17^{\mathrm{b}}$ & 6.60 & $3.9^{b}$ & 34.6 \\
\hline M29-2 & $<2$ & 9.1 & $<0.2$ & $<0.2$ & $4.86^{\mathrm{a}}$ & 0.40 & 3.97 & $15^{\mathrm{b}}$ & 8.76 & $2.8^{\mathrm{b}}$ & 52.8 \\
\hline M29-3 & $<1$ & 7.6 & $<0.3$ & $<0.2$ & $7.8^{\mathrm{b}}$ & $1.4^{\mathrm{e}}$ & 4.57 & $18^{\mathrm{b}}$ & 8.97 & $3.8^{\mathrm{b}}$ & 16.4 \\
\hline M29-4 & $<2$ & 11.8 & $<0.2$ & $<0.4$ & $3.5^{\mathrm{b}}$ & 0.53 & 4.61 & $18^{\mathrm{b}}$ & 9.17 & $2.3^{\mathrm{b}}$ & 6.25 \\
\hline M29-5 & $<2$ & 13 & $<0.3$ & $<0.3$ & $5.6^{\mathrm{b}}$ & 0.65 & 13.1 & $22^{\mathrm{b}}$ & 9.28 & $3.9^{\mathrm{b}}$ & 24.9 \\
\hline M29-6 & $<2$ & 10.5 & $<0.2$ & $<0.3$ & $2.6^{\mathrm{b}}$ & 0.43 & 3.35 & $18^{\mathrm{b}}$ & 8.53 & $2.6^{\mathrm{b}}$ & 13.9 \\
\hline M29-7 & $<2$ & 10.6 & $<0.2$ & $<0.2$ & $3.4^{\mathrm{b}}$ & 0.58 & 5.37 & $16^{\mathrm{b}}$ & 8.54 & $2.2^{\mathrm{b}}$ & 13.9 \\
\hline M29-8 & $<2$ & 11.9 & $<0.2$ & $<0.2$ & $3.4^{\mathrm{b}}$ & 0.51 & 8.03 & $18^{\mathrm{b}}$ & 7.52 & $1.9^{\mathrm{b}}$ & 40.8 \\
\hline M29-9 & $<2$ & 12.8 & $<0.3$ & $<0.3$ & $4.4^{\mathrm{b}}$ & 0.63 & 7.67 & $16^{\mathrm{b}}$ & 6.68 & $2.2^{\mathrm{b}}$ & 20.6 \\
\hline M29-10 & $<2$ & 11.9 & $<0.2$ & $<0.2$ & $3.7^{\mathrm{b}}$ & 0.47 & 5.66 & $18^{\mathrm{b}}$ & 7.22 & $2.1^{\mathrm{b}}$ & 16.9 \\
\hline Average & $<2$ & 10.7 & $<0.2$ & $<0.3$ & $4.4^{\mathrm{b}}$ & 0.52 & 6.08 & $18^{\mathrm{b}}$ & 8.13 & $2.8^{\mathrm{b}}$ & 24.1 \\
\hline Std. Dev. & & 1.8 & & & 1.5 & 0.09 & 2.90 & 2 & 1.03 & 0.8 & 14.4 \\
\hline RSD* & & 17 & & & 34 & 17 & 48 & 11 & 13 & 29 & 60 \\
\hline
\end{tabular}

$\underset{N}{W} *$ Relative standard deviation, $\%$

${ }^{\text {a }}$ Blank corrected (blank) $>10 \%$ of sample value.

${ }^{\mathrm{b}}$ Blank $>30 \%$ of sample value.

${ }^{\mathrm{c}}$ Blank corrected to below deviation limit.

${ }^{\mathrm{d}}$ Relative difference for duplicate trap $>20 \%$. 
Table B2-2d. Plant 2 ME-ST-M Metal Stack Emission, lb/TBtu

\begin{tabular}{|c|c|c|c|c|c|c|c|c|c|c|c|}
\hline & $\mathrm{Sb}$ & As & $\mathrm{Be}$ & $\mathrm{Cd}$ & $\mathrm{Cr}$ & $\mathrm{Co}$ & $\mathrm{Pb}$ & Mn & $\mathrm{Hg}$ & $\mathrm{Ni}$ & $\mathrm{Se}$ \\
\hline TM-3 & 0.38 & 5.06 & $0.08^{b}$ & $0.04^{b}$ & $2.07^{\mathrm{b}, \mathrm{c}}$ & $0.32^{b}$ & $6.3^{b, c}$ & $8.8^{\mathrm{b}, \mathrm{c}}$ & 7.17 & $1.64^{b, c, d}$ & $7.31^{\mathrm{b}}$ \\
\hline TM-4 & $0.37^{\mathrm{a}}$ & 5.60 & $0.08^{b}$ & $0.33^{\mathrm{b}, \mathrm{d}}$ & $17^{\mathrm{c}}$ & 0.43 & $6.6^{\mathrm{b}, \mathrm{c}}$ & $9.8^{\mathrm{b}, \mathrm{c}}$ & 7.21 & $13^{\mathrm{c}, \mathrm{d}}$ & $7.06^{\mathrm{b}}$ \\
\hline TM-5 & 0.39 & 5.72 & $0.09^{b}$ & $0.93^{c}$ & 2.19 & 0.37 & $10.1^{\mathrm{b}, \mathrm{c}}$ & $9.7^{\mathrm{b}, \mathrm{c}, \mathrm{d}}$ & 7.22 & $0.92^{b, c, d}$ & 5.48 \\
\hline TM-6 & $0.35^{\mathrm{a}}$ & 5.69 & $0.07^{\mathrm{b}}$ & $2.2^{\mathrm{c}, \mathrm{d}}$ & $2.77^{\mathrm{b}, \mathrm{c}, \mathrm{d}}$ & 0.36 & $17.9^{\mathrm{b}, \mathrm{c}}$ & $9.0^{\mathrm{b}, \mathrm{c}, \mathrm{d}}$ & 6.86 & $0.83^{b, c, d}$ & 4.64 \\
\hline TM-7 & 0.41 & 6.94 & $0.09^{\mathrm{a}, \mathrm{d}}$ & $0.12^{\mathrm{b}, \mathrm{d}}$ & $2.94^{\mathrm{b}, \mathrm{c}}$ & 0.44 & $9.3^{\mathrm{b}, \mathrm{c}, \mathrm{d}}$ & $8.4^{\mathrm{b}, \mathrm{c}, \mathrm{d}}$ & 6.84 & $2.50^{\mathrm{b}, \mathrm{c}}$ & 5.50 \\
\hline TM-8 & 0.53 & 6.88 & $0.09^{\mathrm{a}}$ & $0.05^{\mathrm{b}}$ & $3.36^{\mathrm{b}, \mathrm{c}}$ & 0.35 & $16.4^{\mathrm{b}, \mathrm{c}, \mathrm{d}}$ & $3.7^{\mathrm{b}, \mathrm{c}}$ & 6.16 & $2.95^{\mathrm{b}, \mathrm{c}}$ & 6.65 \\
\hline TM-9 & 0.58 & 7.65 & $0.10^{\mathrm{a}}$ & $0.11^{\mathrm{b}, \mathrm{d}}$ & $3.10^{\mathrm{b}, \mathrm{c}}$ & 0.50 & $14.1^{\mathrm{b}, \mathrm{c}}$ & $5.0^{\mathrm{b}, \mathrm{c}}$ & 5.86 & $1.57^{\mathrm{b}, \mathrm{c}, \mathrm{d}}$ & 6.68 \\
\hline TM-10 & 0.51 & 7.81 & $0.07^{\mathrm{a}}$ & $0.25^{\mathrm{b}, \mathrm{d}}$ & $3.55^{\mathrm{b}, \mathrm{c}}$ & 0.43 & $12.3^{\mathrm{b}, \mathrm{c}}$ & $4.6^{\mathrm{b}, \mathrm{c}}$ & 5.93 & $1.99^{\mathrm{b}, \mathrm{c}, \mathrm{d}}$ & 6.32 \\
\hline TM-11 & 0.37 & 5.27 & $0.07^{b}$ & $0.06^{\mathrm{b}}$ & $1.76^{\mathrm{b}, \mathrm{c}}$ & 0.27 & $10.2^{\mathrm{b}, \mathrm{c}}$ & $3.0^{\mathrm{b}, \mathrm{c}}$ & 6.13 & $1.37^{\mathrm{b}, \mathrm{c}, \mathrm{d}}$ & 5.00 \\
\hline Average & 0.43 & 6.29 & $0.08^{b}$ & $0.46^{\mathrm{b}}$ & $4.26^{\mathrm{b}}$ & 0.39 & $11.5^{\mathrm{b}}$ & $6.9^{\mathrm{b}}$ & 6.60 & $2.98^{\mathrm{b}}$ & 6.07 \\
\hline Std. Dev. & 0.08 & 1.04 & 0.01 & 0.72 & 4.67 & 0.07 & 4.0 & 2.8 & 0.57 & 3.84 & 0.95 \\
\hline RSD* & 19 & 17 & 11 & 159 & 110 & 18 & 35 & 40 & 9 & 129 & 16 \\
\hline
\end{tabular}

* Relative standard deviation, $\%$

${ }^{\text {a }}$ Blank corrected (blank) $>10 \%$ of sample value.

${ }^{\mathrm{b}}$ Blank $>30 \%$ of sample value.

${ }^{\mathrm{c}}$ Blank corrected to below deviation limit.

${ }^{\mathrm{d}}$ Relative difference for duplicate trap $>20 \%$. 
Table B2-2e. Plant 2 ME-ST-M Metal Stack Emission, $\mu \mathrm{g} / \mathrm{dNm}^{3}$ at $3 \% \mathrm{O}_{2}$

\begin{tabular}{|c|c|c|c|c|c|c|c|c|c|c|c|}
\hline & $\mathrm{Sb}$ & As & $\mathrm{Be}$ & $\mathrm{Cd}$ & $\mathrm{Cr}$ & $\mathrm{Co}$ & $\mathrm{Pb}$ & $\mathrm{Mn}$ & $\mathrm{Hg}$ & $\mathrm{Ni}$ & $\mathrm{Se}$ \\
\hline TM-3 & 0.51 & 6.82 & $0.10^{b}$ & $0.05^{b}$ & $2.80^{b, c}$ & $0.43^{b}$ & $8.55^{b, c}$ & $11.8^{\mathrm{b}, \mathrm{c}}$ & 9.67 & $2.21^{b, c, d}$ & 9.86 \\
\hline TM-4 & $0.50^{\mathrm{a}}$ & 7.55 & $0.11^{b}$ & $0.44^{\mathrm{b}, \mathrm{d}}$ & $22^{b, c}$ & 0.59 & $8.93^{\mathrm{b}, \mathrm{c}}$ & $13.2^{\mathrm{b}, \mathrm{c}}$ & 9.72 & $18^{\mathrm{b}, \mathrm{c}}$ & 9.52 \\
\hline TM-5 & 0.53 & 7.71 & $0.12^{b}$ & $1.2^{\mathrm{a}}$ & $2.95^{\mathrm{c}}$ & 0.50 & $13.6^{\mathrm{b}, \mathrm{c}}$ & $13.1^{\mathrm{b}, \mathrm{c}, \mathrm{d}}$ & 9.73 & $1.24^{\mathrm{b}, \mathrm{c}, \mathrm{d}}$ & 7.39 \\
\hline TM-6 & $0.47^{\mathrm{a}}$ & 7.67 & $0.10^{\mathrm{b}}$ & $3.0^{\mathrm{a}}$ & $3.73^{\mathrm{b}, \mathrm{c}, \mathrm{d}}$ & 0.48 & $24.1^{\mathrm{b}, \mathrm{c}}$ & $12.2^{\mathrm{b}, \mathrm{c}, \mathrm{d}}$ & 9.26 & $1.12^{\mathrm{b}, \mathrm{c}, \mathrm{d}}$ & 6.26 \\
\hline TM-7 & 0.55 & 9.35 & $0.12^{\mathrm{a}, \mathrm{d}}$ & $0.16^{\mathrm{b}, \mathrm{d}}$ & $3.96^{\mathrm{b}, \mathrm{c}}$ & 0.59 & $12.6^{\mathrm{b}, \mathrm{c}, \mathrm{d}}$ & $11.3^{\mathrm{b}, \mathrm{c}, \mathrm{d}}$ & 9.22 & $3.37^{\mathrm{b}, \mathrm{c}}$ & 7.41 \\
\hline TM-8 & 0.71 & 9.28 & $0.13^{\mathrm{a}}$ & $0.06^{\mathrm{b}}$ & $4.53^{\mathrm{b}, \mathrm{c}}$ & 0.48 & $22.2^{\mathrm{b}, \mathrm{c}, \mathrm{d}}$ & $5.00^{\mathrm{b}, \mathrm{c}}$ & 8.31 & $3.97^{\mathrm{b}, \mathrm{c}}$ & 8.97 \\
\hline TM-9 & 0.78 & 10.3 & $0.13^{\mathrm{a}}$ & $0.14^{\mathrm{b}, \mathrm{d}}$ & $4.19^{\mathrm{b}, \mathrm{c}}$ & 0.67 & $19.0^{\mathrm{b}, \mathrm{c}}$ & $6.73^{b, c}$ & 7.90 & $2.11^{\mathrm{b}, \mathrm{c}, \mathrm{d}}$ & 9.01 \\
\hline TM-10 & 0.68 & 10.5 & $0.10^{\mathrm{a}}$ & $0.34^{\mathrm{b}, \mathrm{d}}$ & $4.79^{b, c}$ & 0.58 & $16.6^{\mathrm{b}, \mathrm{c}}$ & $6.18^{\mathrm{b}, \mathrm{c}}$ & 7.99 & $2.69^{\mathrm{b}, \mathrm{c}, \mathrm{d}}$ & 8.52 \\
\hline TM-11 & 0.50 & 7.11 & $0.10^{\mathrm{b}}$ & $0.08^{\mathrm{b}}$ & $2.37^{\mathrm{b}, \mathrm{c}}$ & 0.36 & $13.8^{\mathrm{b}, \mathrm{c}}$ & $4.10^{\mathrm{b}, \mathrm{c}}$ & 8.26 & $1.85^{\mathrm{b}, \mathrm{c}, \mathrm{d}}$ & 6.74 \\
\hline Average & 0.58 & 8.48 & $0.11^{b}$ & $0.62^{b}$ & $5.74^{\mathrm{b}}$ & 0.52 & $15.5^{\mathrm{b}}$ & $9.3^{\mathrm{b}}$ & 8.90 & $4.02^{b}$ & 8.19 \\
\hline Std. Dev. & 0.11 & 1.40 & 0.01 & 0.98 & 6.30 & 0.09 & 5.5 & 3.7 & 0.77 & 5.18 & 1.28 \\
\hline RSD* & 19 & 17 & 11 & 159 & 110 & 18 & 35 & 40 & 9 & 129 & 16 \\
\hline
\end{tabular}

* Relative standard deviation, $\%$

${ }^{\text {a }}$ Blank corrected (blank) $>10 \%$ of sample value.

${ }^{\mathrm{b}}$ Blank $>30 \%$ of sample value.

${ }^{\mathrm{c}}$ Blank corrected to below deviation limit.

${ }^{\mathrm{d}}$ Relative difference for duplicate trap $>20 \%$. 
Table B2-3a. Plant 3 Estimated Metals Capture

\begin{tabular}{lcccccccccccc}
\hline & $\mathrm{Sb}$ & $\mathrm{As}$ & $\mathrm{Be}$ & $\mathrm{Cd}$ & $\mathrm{Cr}$ & $\mathrm{Co}$ & $\mathrm{Pb}$ & $\mathrm{Mn}$ & $\mathrm{Hg}$ & $\mathrm{Ni}$ & $\mathrm{Se}$ \\
\hline MATS & 0.8 & 1.1 & 0.2 & 0.3 & 2.8 & 0.8 & 1.2 & 4.0 & 4.0 & 3.5 & 5.0 & 25 \\
Coal & 36 & 490 & 39 & 6 & 540 & 174 & 336 & 8433 & 14.7 & 227 & 64 \\
M29 & $<0.7$ & 6.22 & 0.248 & 0.357 & $3.12^{\mathrm{b}}$ & 0.637 & $1.98^{\mathrm{b}}$ & $53.3^{\mathrm{b}}$ & 2.76 & $3.36^{\mathrm{b}}$ & 5.88 \\
Capture & $>98$ & 98.7 & 99.4 & 94.3 & 99.4 & 99.6 & 99.4 & 99.4 & 81.2 & 98.5 & 90.9 \\
ME-ST & $0.430^{\mathrm{a}}$ & 8.04 & $0.37^{\mathrm{a}}$ & $0.71^{\mathrm{c}}$ & $20.9^{\mathrm{c}}$ & $1.02^{\mathrm{b}}$ & $4.5^{\mathrm{c}}$ & $100^{\mathrm{b}}$ & 2.68 & $17.9^{\mathrm{c}}$ & $4.11^{\mathrm{b}}$ \\
Capture & 98.8 & 98.4 & 99.1 & 88.7 & 96.1 & 99.4 & 98.6 & 98.8 & 81.8 & 92.1 & 93.6 \\
\hline
\end{tabular}

${ }^{\mathrm{a}}$ Blank corrected (blank) $>10 \%$ of sample value.

${ }^{\mathrm{b}}$ Blank $>30 \%$ of sample value.

${ }^{\mathrm{c}}$ Blank corrected to below deviation limit.

${ }^{\mathrm{d}}$ Relative difference for duplicate trap $>20 \%$.

Table B2-3b. Plant 3 EPA Method 29 Metal Stack Emission, lb/TBtu

\begin{tabular}{|c|c|c|c|c|c|c|c|c|c|c|c|}
\hline & $\mathrm{Sb}$ & As & $\mathrm{Be}$ & $\mathrm{Cd}$ & $\mathrm{Cr}$ & $\mathrm{Co}$ & $\mathrm{Pb}$ & $\mathrm{Mn}$ & $\mathrm{Hg}$ & $\mathrm{Ni}$ & $\mathrm{Se}$ \\
\hline M29-1 & $<0.7$ & 6.88 & 0.287 & 0.443 & $2.09^{b}$ & 0.681 & $2.76^{\mathrm{a}}$ & $49.7^{b}$ & 2.32 & $6.42^{b}$ & 6.21 \\
\hline M29-2 & $<0.8$ & 4.15 & 0.194 & 0.335 & $2.85^{\mathrm{b}}$ & 0.588 & 1.67 & $50.2^{\mathrm{b}}$ & 2.63 & $4.15^{b}$ & 5.85 \\
\hline M29-3 & $<0.8$ & 5.13 & 0.234 & 0.356 & $3.63^{\mathrm{a}}$ & 0.625 & $1.80^{\mathrm{b}}$ & $56.0^{\mathrm{b}}$ & 2.98 & $3.84^{\mathrm{b}}$ & 6.32 \\
\hline M29-4 & $<0.7$ & 6.78 & 0.244 & 0.407 & $4.80^{b}$ & 0.668 & 1.87 & $65.0^{\mathrm{b}}$ & 2.20 & $4.64^{b}$ & 6.04 \\
\hline M29-5 & $<0.7$ & 6.36 & 0.226 & 0.307 & $4.62^{\mathrm{a}}$ & 0.650 & 1.83 & $62.2^{\mathrm{b}}$ & 2.43 & $4.00^{\mathrm{b}}$ & 5.88 \\
\hline M29-6 & $<0.7$ & 5.13 & 0.219 & 0.343 & $2.18^{b}$ & 0.573 & 1.82 & 43.8 & 3.14 & $1.74^{\mathrm{b}}$ & 5.77 \\
\hline M29-7 & $<0.7$ & 6.02 & 0.248 & 0.320 & $3.01^{\mathrm{b}}$ & 0.599 & 1.70 & $47.1^{\mathrm{b}}$ & 2.96 & $2.27^{\mathrm{b}}$ & 5.60 \\
\hline M29-8 & $<0.8$ & 6.97 & 0.268 & 0.335 & $2.51^{\mathrm{b}}$ & 0.638 & 2.16 & 51.1 & 3.05 & $1.60^{\mathrm{b}}$ & 5.57 \\
\hline M29-11 & $<0.8$ & 8.52 & 0.309 & 0.363 & $2.42^{\mathrm{b}}$ & 0.710 & 2.25 & 54.1 & 3.17 & $1.59^{\mathrm{b}}$ & 5.68 \\
\hline Average & $<0.7$ & 6.22 & 0.248 & 0.357 & $3.12^{\mathrm{b}}$ & 0.637 & $1.98^{\mathrm{b}}$ & $53.3^{b}$ & 2.76 & $3.36^{\mathrm{b}}$ & 5.88 \\
\hline Std. Dev. & & 1.29 & 0.035 & 0.043 & 1.01 & 0.045 & 0.35 & 6.9 & 0.37 & 1.67 & 0.26 \\
\hline RSD* & & 21 & 14 & 12 & 32 & 7 & 18 & 13 & 13 & 50 & 4 \\
\hline
\end{tabular}

* Relative standard deviation, $\%$.

${ }^{a}$ Blank corrected (blank) $>10 \%$ of sample value.

${ }^{\mathrm{b}}$ Blank $>30 \%$ of sample value.

${ }^{\mathrm{c}}$ Blank corrected to below deviation limit.

${ }^{\mathrm{d}}$ Relative difference for duplicate trap $>20 \%$. 
Table B2-3c. Plant 3 EPA Method 29 Metal Stack Emission, $\mu$ g/dNm ${ }^{3}$ at $3 \% \mathrm{O}_{2}$

\begin{tabular}{llllllllllll}
\hline & $\mathrm{Sb}$ & $\mathrm{As}$ & $\mathrm{Be}$ & $\mathrm{Cd}$ & $\mathrm{Cr}$ & $\mathrm{Co}$ & $\mathrm{Pb}$ & $\mathrm{Mn}$ & $\mathrm{Hg}$ & $\mathrm{Ni}$ & $\mathrm{Se}$ \\
\hline M29-1 & $<1$ & 9.49 & 0.396 & 0.611 & $2.88^{\mathrm{b}}$ & 0.939 & $3.81^{\mathrm{a}}$ & $68.6^{\mathrm{b}}$ & 3.20 & $8.86^{\mathrm{b}}$ & 8.57 \\
M29-2 & $<1$ & 5.73 & 0.268 & 0.462 & $3.93^{\mathrm{b}}$ & 0.811 & 2.30 & $69.2^{\mathrm{b}}$ & 3.62 & $5.72^{\mathrm{b}}$ & 8.07 \\
M29-3 & $<1$ & 7.08 & 0.323 & 0.492 & $5.01^{\mathrm{a}}$ & 0.862 & $2.48^{\mathrm{b}}$ & $77.3^{\mathrm{b}}$ & 4.10 & $5.29^{\mathrm{b}}$ & 8.72 \\
M29-4 & $<1$ & 9.36 & 0.337 & 0.561 & $6.62^{\mathrm{b}}$ & 0.921 & 2.58 & $89.7^{\mathrm{b}}$ & 3.04 & $6.40^{\mathrm{b}}$ & 8.33 \\
M29-5 & $<1$ & 8.77 & 0.312 & 0.423 & $6.37^{\mathrm{a}}$ & 0.896 & 2.52 & $85.8^{\mathrm{b}}$ & 3.35 & $5.52^{\mathrm{b}}$ & 8.10 \\
M29-6 & $<1$ & 7.08 & 0.301 & 0.473 & $3.00^{\mathrm{b}}$ & 0.791 & 2.51 & 60.4 & 4.33 & $2.40^{\mathrm{b}}$ & 7.96 \\
M29-7 & $<1$ & 8.30 & 0.342 & 0.441 & $4.15^{\mathrm{b}}$ & 0.826 & 2.34 & $64.9^{\mathrm{b}}$ & 4.08 & $3.14^{\mathrm{b}}$ & 7.72 \\
M29-8 & $<1$ & 9.62 & 0.369 & 0.462 & $3.46^{\mathrm{b}}$ & 0.879 & 2.97 & 70.5 & 4.20 & $2.20^{\mathrm{b}}$ & 7.68 \\
M29-11 & $<1$ & 11.7 & 0.426 & 0.50 & $3.34^{\mathrm{b}}$ & 0.980 & 3.10 & 74.6 & 4.37 & $2.20^{\mathrm{b}}$ & 7.83 \\
Average & $<1$ & 8.57 & 0.342 & 0.492 & $4.31^{\mathrm{b}}$ & 0.878 & 2.73 & $73.5^{\mathrm{b}}$ & 3.81 & $4.64^{\mathrm{b}}$ & 8.11 \\
Std. Dev. & & 1.78 & 0.049 & 0.060 & 1.40 & 0.062 & 0.48 & 9.5 & 0.51 & 2.30 & 0.36 \\
RSD* & & 21 & 14 & 12 & 32 & 7 & 18 & 13 & 13 & 50 & 4 \\
\hline
\end{tabular}

\footnotetext{
$\underset{N}{\square} \quad{ }^{\text {* }}$ Relative standard deviation, $\%$.

${ }^{\mathrm{c}}$ Blank corrected to below deviation limit.

${ }^{\mathrm{d}}$ Relative difference for duplicate trap $>20 \%$.
} 
Table B2-3d. Plant 3 ME-ST-M Metal Stack Emission, lb/TBtu

\begin{tabular}{lccccccccccc}
\hline & $\mathrm{Sb}$ & $\mathrm{As}$ & $\mathrm{Be}$ & $\mathrm{Cd}$ & $\mathrm{Cr}$ & $\mathrm{Co}$ & $\mathrm{Pb}$ & $\mathrm{Mn}$ & $\mathrm{Hg}$ & $\mathrm{Ni}$ & $\mathrm{Se}$ \\
\hline TM-1 & $0.604^{\mathrm{a}}$ & 18.2 & $0.64^{\mathrm{a}}$ & $0.14^{\mathrm{c}}$ & $8.8^{\mathrm{b}}$ & $1.01^{\mathrm{b}}$ & $1.95^{\mathrm{b}}$ & $115^{\mathrm{a}}$ & 1.91 & $3.17^{\mathrm{c}, \mathrm{d}}$ & $4.07^{\mathrm{b}}$ \\
TM-2 & $0.235^{\mathrm{a}}$ & $2.50^{\mathrm{a}}$ & $0.45^{\mathrm{a}, \mathrm{d}}$ & $2.88^{\mathrm{c}, \mathrm{d}}$ & $32.5^{\mathrm{a}, \mathrm{d}}$ & $0.85^{\mathrm{a}, \mathrm{d}}$ & $24.1^{\mathrm{d}}$ & 91 & 2.66 & 60.3 & $3.41^{\mathrm{b}}$ \\
TM-3 & $0.313^{\mathrm{a}}$ & $6.80^{\mathrm{a}, \mathrm{d}}$ & $0.26^{\mathrm{a}, \mathrm{d}}$ & $0.10^{\mathrm{b}, \mathrm{d}}$ & $42.5^{\mathrm{b}, \mathrm{d}}$ & $1.00^{\mathrm{a}, \mathrm{d}}$ & $0.96^{\mathrm{b}}$ & $85^{\mathrm{a}, \mathrm{d}}$ & 3.24 & $28.5^{\mathrm{a}, \mathrm{d}}$ & $4.19^{\mathrm{b}}$ \\
TM-4 & $0.483^{\mathrm{a}}$ & 8.59 & $0.34^{\mathrm{a}}$ & $0.14^{\mathrm{b}}$ & $6.74^{\mathrm{a}}$ & $1.18^{\mathrm{a}}$ & $0.64^{\mathrm{c}}$ & 120 & 2.15 & $3.39^{\mathrm{c}, \mathrm{d}}$ & $5.01^{\mathrm{b}}$ \\
TM-5 & $0.420^{\mathrm{a}}$ & 6.54 & $0.28^{\mathrm{a}}$ & $0.06^{\mathrm{c}, \mathrm{d}}$ & $37.8^{\mathrm{a}}$ & $1.22^{\mathrm{a}}$ & $1.05^{\mathrm{c}}$ & 116 & 2.41 & $30.0^{\mathrm{c}, \mathrm{d}}$ & 4.40 \\
TM-6 & $0.471^{\mathrm{a}}$ & 8.14 & $0.34^{\mathrm{a}}$ & $0.14^{\mathrm{b}, \mathrm{d}}$ & $7.1^{\mathrm{a}}$ & $0.98^{\mathrm{a}, \mathrm{d}}$ & $1.48^{\mathrm{c}}$ & $107^{\mathrm{a}}$ & 3.29 & $5.55^{\mathrm{c}, \mathrm{d}}$ & 4.28 \\
TM-7 & $0.364^{\mathrm{a}}$ & 5.68 & $0.26^{\mathrm{a}}$ & $<0.04^{\mathrm{c}}$ & $10.6^{\mathrm{c}, \mathrm{d}}$ & $0.71^{\mathrm{b}}$ & $5.47^{\mathrm{c}, \mathrm{d}}$ & $64^{\mathrm{a}}$ & 2.94 & $3.97^{\mathrm{c}, \mathrm{d}}$ & 3.89 \\
TM-8 & $0.411^{\mathrm{a}}$ & $7.26^{\mathrm{d}}$ & $0.31^{\mathrm{a}}$ & $0.16^{\mathrm{b}, \mathrm{d}}$ & $36.4^{\mathrm{b}, \mathrm{d}}$ & $1.16^{\mathrm{a}}$ & $1.29^{\mathrm{c}}$ & $95^{\mathrm{b}}$ & 2.75 & $22.3^{\mathrm{c}, \mathrm{d}}$ & 3.70 \\
TM-11 & $0.565^{\mathrm{a}, \mathrm{d}}$ & 8.64 & $0.44^{\mathrm{a}}$ & $2.76^{\mathrm{c}, \mathrm{d}}$ & $5.44^{\mathrm{c}}$ & $1.05^{\mathrm{a}}$ & $4.93^{\mathrm{c}, \mathrm{d}}$ & $107^{\mathrm{b}}$ & 2.76 & $3.56^{\mathrm{c}, \mathrm{d}}$ & 3.99 \\
Average & $0.430^{\mathrm{a}}$ & 8.04 & $0.37^{\mathrm{a}}$ & $0.71^{\mathrm{c}}$ & $20.9^{\mathrm{c}}$ & $1.02^{\mathrm{b}}$ & $4.65^{\mathrm{c}}$ & $100^{\mathrm{b}}$ & 2.68 & $17.9^{\mathrm{c}}$ & $4.11^{\mathrm{b}}$ \\
Std. Dev. & 0.117 & 4.26 & 0.12 & 1.20 & 15.8 & 0.16 & 7.51 & 18 & 0.46 & 19.5 & 0.45 \\
RSD & 27 & 53 & 33 & 168 & 76 & 16 & 161 & 18 & 17 & 109 & 11 \\
\hline
\end{tabular}

\footnotetext{
$\underset{N}{\mathbb{N}} \quad \begin{aligned} & \text { * Relative standard deviation, } \% \text {. } \\ & \text { a Blank corrected (blank) }>10 \% \text { of sample value. }\end{aligned}$

${ }^{\mathrm{c}}$ Blank corrected to below deviation limit.

${ }^{\mathrm{d}}$ Relative difference for duplicate trap $>20 \%$.
} 
Table B2-3e. Plant 3 ME-ST-M Metal Stack Emission, $\mu \mathrm{g} / \mathrm{dNm}^{3}$ at $3 \% \mathrm{O}_{2}$

\begin{tabular}{lccccccccccc}
\hline & $\mathrm{Sb}$ & $\mathrm{As}$ & $\mathrm{Be}$ & $\mathrm{Cd}$ & $\mathrm{Cr}$ & $\mathrm{Co}$ & $\mathrm{Pb}$ & $\mathrm{Mn}$ & $\mathrm{Hg}$ & $\mathrm{Ni}$ & $\mathrm{Se}$ \\
\hline TM-1 & $0.833^{\mathrm{a}}$ & 25.1 & $0.885^{\mathrm{a}}$ & $0.188^{\mathrm{c}}$ & $12.1^{\mathrm{b}}$ & $1.39^{\mathrm{b}}$ & $2.69^{\mathrm{b}}$ & $158^{\mathrm{a}}$ & 2.63 & $4.37^{\mathrm{c}, \mathrm{d}}$ & 5.61 \\
TM-2 & $0.324^{\mathrm{a}}$ & $3.45^{\mathrm{a}}$ & $0.63^{\mathrm{a}, \mathrm{d}}$ & $3.98^{\mathrm{c}, \mathrm{d}}$ & $44.8^{\mathrm{a}, \mathrm{d}}$ & $1.18^{\mathrm{a}, \mathrm{d}}$ & $33.3^{\mathrm{d}}$ & 126 & 3.67 & 83.1 & 4.70 \\
TM-3 & $0.432^{\mathrm{a}}$ & $9.38^{\mathrm{a}, \mathrm{d}}$ & $0.36^{\mathrm{a}, \mathrm{d}}$ & $0.13^{\mathrm{b}, \mathrm{d}}$ & $58.6^{\mathrm{b}, \mathrm{d}}$ & $1.38^{\mathrm{a}, \mathrm{d}}$ & $1.33^{\mathrm{b}}$ & $117^{\mathrm{a}, \mathrm{d}}$ & 4.47 & $39.4^{\mathrm{a}, \mathrm{d}}$ & 5.78 \\
TM-4 & $0.666^{\mathrm{a}}$ & 11.8 & $0.463^{\mathrm{a}}$ & $0.19^{\mathrm{b}}$ & $9.30^{\mathrm{a}}$ & $1.62^{\mathrm{a}}$ & $0.877^{\mathrm{c}}$ & 165 & 2.97 & $4.68^{\mathrm{c}, \mathrm{d}}$ & 6.91 \\
TM-5 & $0.579^{\mathrm{a}}$ & 9.03 & $0.39^{\mathrm{a}}$ & $0.076^{\mathrm{c}, \mathrm{d}}$ & 52.2 & $1.69^{\mathrm{a}}$ & $1.44^{\mathrm{c}}$ & 161 & 3.32 & $41.3^{\mathrm{c}, \mathrm{d}}$ & 6.07 \\
TM-6 & $0.650^{\mathrm{a}}$ & 11.2 & $0.462^{\mathrm{a}}$ & $0.190^{\mathrm{b}, \mathrm{d}}$ & $9.8^{\mathrm{a}}$ & $1.35^{\mathrm{a}, \mathrm{d}}$ & $2.04^{\mathrm{c}}$ & $148^{\mathrm{a}}$ & 4.53 & $7.66^{\mathrm{c}, \mathrm{d}}$ & 5.90 \\
TM-7 & $0.502^{\mathrm{a}}$ & 7.8 & $0.364^{\mathrm{a}}$ & $<0.05^{\mathrm{c}}$ & $14.7^{\mathrm{c}, \mathrm{d}}$ & $0.98^{\mathrm{b}}$ & $7.55^{\mathrm{c}, \mathrm{d}}$ & $88.8^{\mathrm{a}}$ & 4.06 & $5.47^{\mathrm{c}, \mathrm{d}}$ & 5.37 \\
TM-8 & $0.567^{\mathrm{a}}$ & $10.0^{\mathrm{d}}$ & $0.43^{\mathrm{a}}$ & $0.22^{\mathrm{b}, \mathrm{d}}$ & $50.2^{\mathrm{b}, \mathrm{d}}$ & $1.60^{\mathrm{a}}$ & $1.77^{\mathrm{c}}$ & $131^{\mathrm{b}}$ & 3.79 & $30.8^{\mathrm{c}, \mathrm{d}}$ & 5.10 \\
TM-11 & $0.779^{\mathrm{a}, \mathrm{d}}$ & 11.9 & $0.605^{\mathrm{a}}$ & $3.81^{\mathrm{c}, \mathrm{d}}$ & $7.50^{\mathrm{c}}$ & $1.44^{\mathrm{a}}$ & $6.80^{\mathrm{c}, \mathrm{d}}$ & $147^{\mathrm{b}}$ & 3.80 & $4.90^{\mathrm{c}, \mathrm{d}}$ & 5.51 \\
Average & $0.592^{\mathrm{a}}$ & 11.1 & $0.51^{\mathrm{a}}$ & $0.98^{\mathrm{c}}$ & $28.8^{\mathrm{c}}$ & $1.40^{\mathrm{b}}$ & $6.42^{\mathrm{c}}$ & $138^{\mathrm{b}}$ & 3.69 & $24.6^{\mathrm{c}}$ & 5.66 \\
Std. Dev. & 0.161 & 5.88 & 0.17 & 1.65 & 21.8 & 0.22 & 10.35 & 25 & 0.64 & 26.9 & 0.63 \\
RSD* & 27 & 53 & 33 & 168 & 76 & 16 & 161 & 18 & 17 & 109 & 11 \\
\hline
\end{tabular}

\footnotetext{
$\begin{array}{ll}\varpi & * \text { Relative standard deviation, } \% \text {. } \\ & { }^{\mathrm{b}} \text { Blank corrected (blank) }>10 \% \text { of sample value. }\end{array}$

${ }^{\mathrm{c}}$ Blank corrected to below deviation limit.

${ }^{\mathrm{d}}$ Relative difference for duplicate trap $>20 \%$.
} 
APPENDIX C

\section{ELEMENT-BY-ELEMENT METHOD COMPARISON}




\section{ELEMENT-BY-ELEMENT METHOD COMPARISON}

\section{POWER PLANT 1}

\section{Antimony, Sb}

The $\mathrm{Sb}$ results for Plant 1 are shown in Figure $\mathrm{C}-1$. The lack of error bars on the average data indicates that the data are below the detection limits. The Mercury and Air Toxics Standards (MATS) limit is $0.8 \mathrm{lb} / \mathrm{TBtu}$ (approximately $1.08 \mu \mathrm{g} / \mathrm{dNm}^{3}$ at $3 \% \mathrm{O}_{2}$ ) for plants burning lignite for both new and existing sources. As sampled, it can be seen that the EPA Method (M) 29 is not able to report at this level. The multielement sorbent trap multimetals (ME-ST-M) method data for this data set are not valid because of the background correction, but the comparison of the data indicates that the alternative method is equivalent to the EPA M29 reference method since all of the data are less than values. The ME-ST-M shows a much lower detection limit than M29.

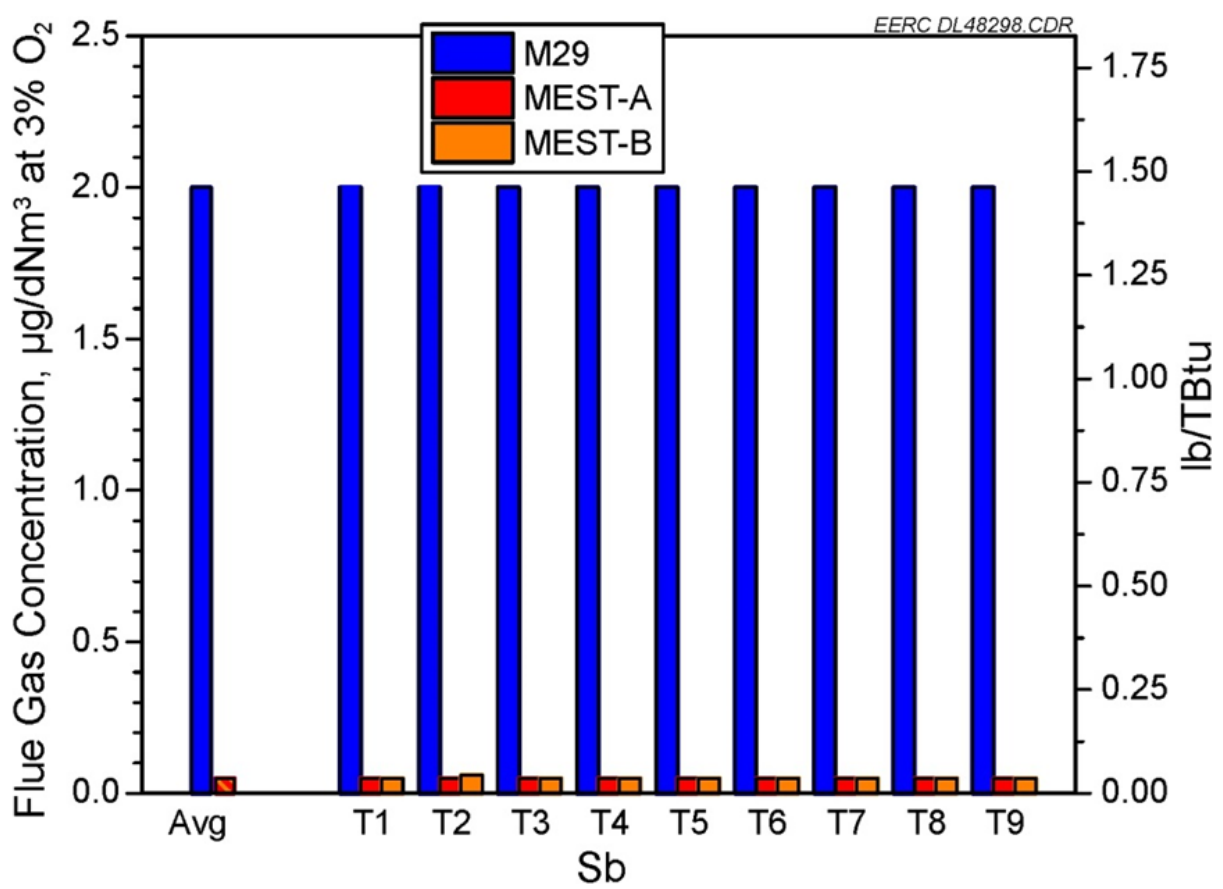

Figure C-1. Comparison of U.S. Environmental Protection Agency (EPA) M29 and ME-ST-M data for antimony, Plant 1. 


\section{Arsenic, As}

The As results for Plant 1 are shown in Figure C-2. The lack of error bars on the average data indicates that the data are below the detection limits. For plants burning lignite, the MATS limits are $1.1 \mathrm{lb} / \mathrm{TBtu}$ (approximately $2.65 \mu \mathrm{g} / \mathrm{dNm}^{3}$ at $3 \% \mathrm{O}_{2}$ ) for existing sources and $0.003 \mathrm{lb} / \mathrm{TBtu}$ (approximately $0.40 \mu \mathrm{g} / \mathrm{dNm}^{3}$ at $3 \% \mathrm{O}_{2}$ ) for new sources. It can be seen that the EPA M29 method is very near the limit for new sources. The ME-ST-M method data for this data set are not valid because of the background correction, but the comparison of the data indicates that the alternative method is equivalent to the EPA M29 reference method since all of the data are less than values. The ME-ST-M shows a much lower detection limit than M29.

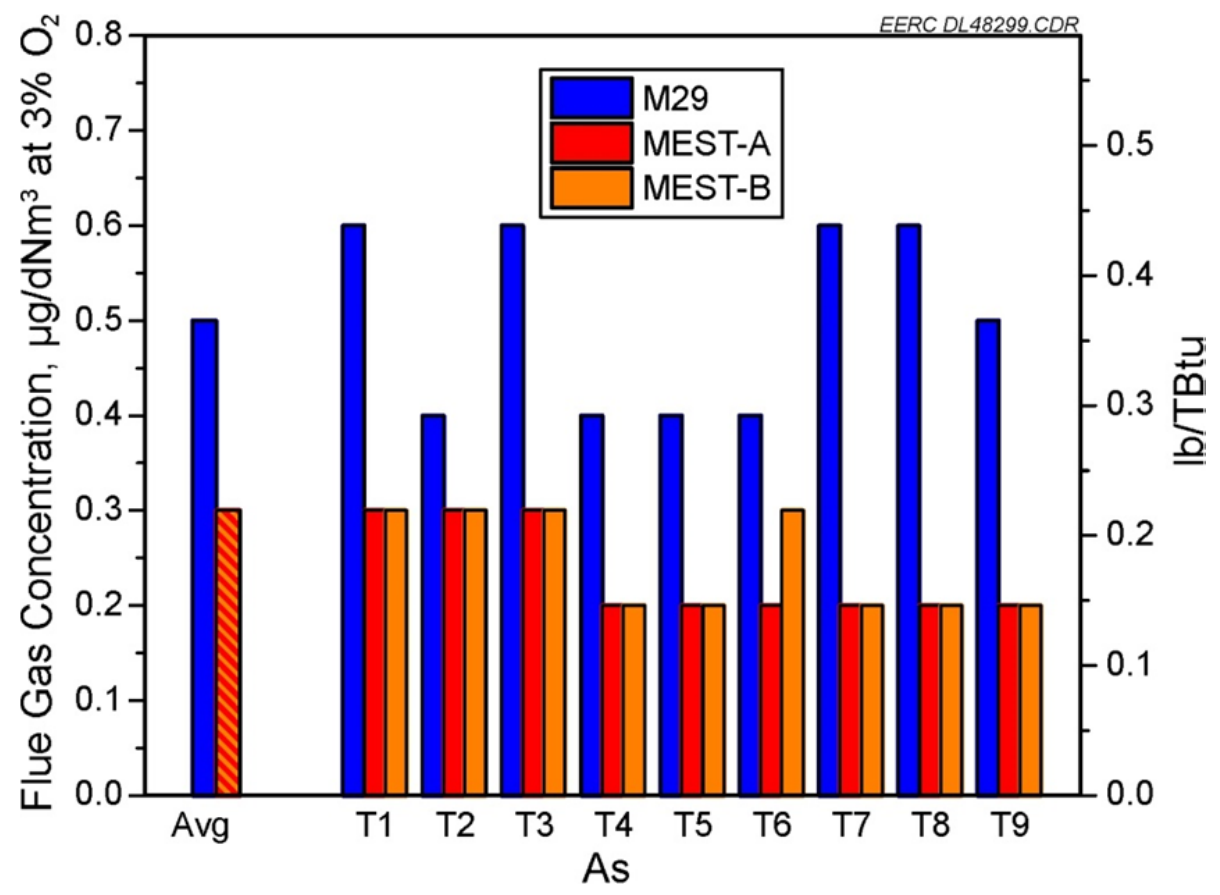

Figure C-2. Comparison of EPA M29 and ME-ST-M data for arsenic, Plant 1. 


\section{Beryllium, Be}

The Be results for Plant 1 are shown in Figure C-3. The lack of error bars on the average data indicates that the data are below the detection limits. For plants burning lignite, the MATS limits are $0.20 \mathrm{lb} /$ TBtu (approximately $0.27 \mu \mathrm{g} / \mathrm{dNm}^{3}$ at $3 \% \mathrm{O}_{2}$ ) for existing sources and $0.0006 \mathrm{lb} / \mathrm{TBtu}$ (approximately $0.073 \mu \mathrm{g} / \mathrm{dNm}^{3}$ at $3 \% \mathrm{O}_{2}$ ) for new sources. As sampled, it can be seen that the EPA M29 is not able to report at this level for new sources. The ME-ST-M method data for this data set are not valid because of the background correction, but the comparison of the data indicates that the alternative method is equivalent to the EPA M29 reference method since all of the data are less than values. The ME-ST-M shows a much lower detection limit than M29.

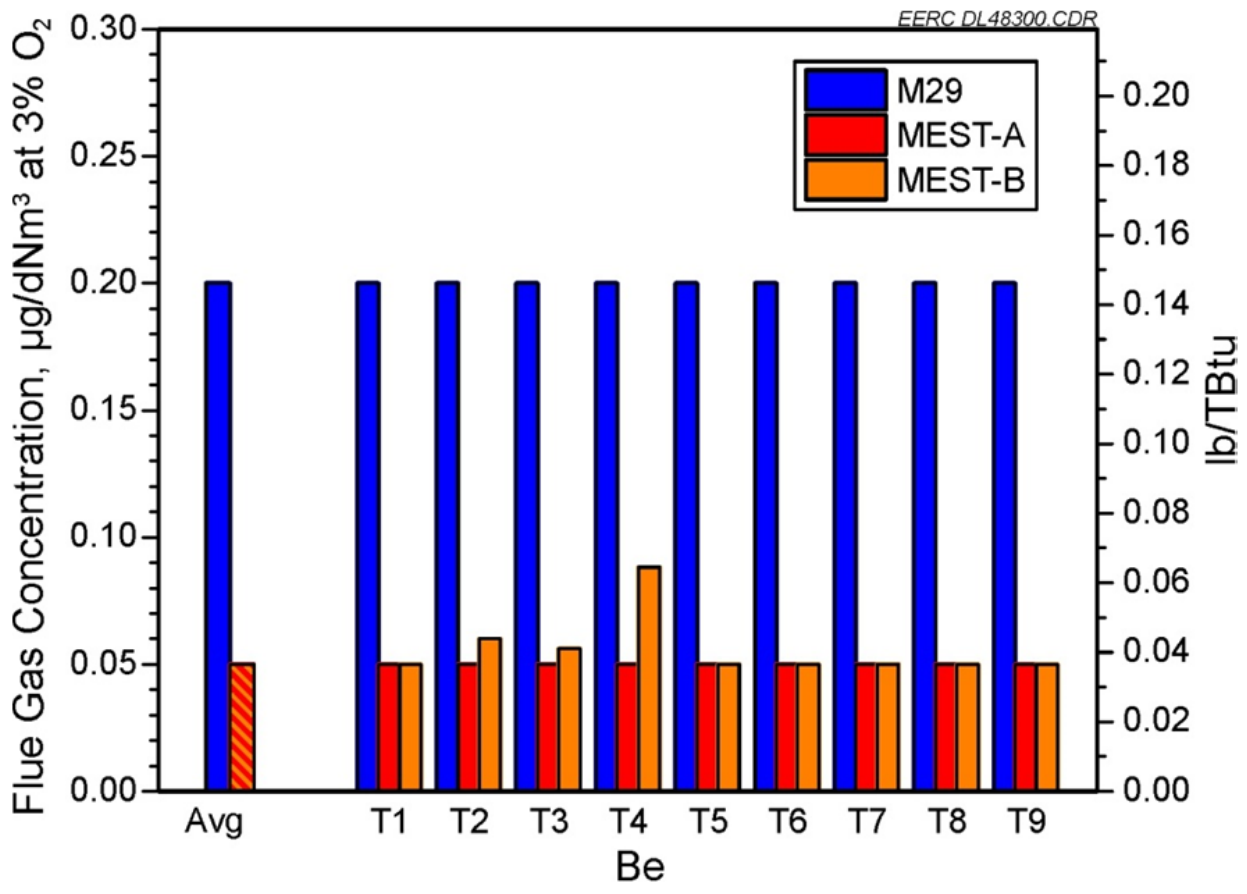

Figure C-3. Comparison of EPA M29 and ME-ST-M data for beryllium, Plant 1. 


\section{Cadmium, Cd}

The Cd results for Plant 1 are shown in Figure C-4. The lack of error bars for the EPA M29 average data indicates that the data are below the detection limit. For plants burning lignite, the MATS limits are $0.3 \mathrm{lb} / \mathrm{TBtu}$ (approximately $0.41 \mu \mathrm{g} / \mathrm{dNm}^{3}$ at $3 \% \mathrm{O}_{2}$ ) for existing sources and $0.0004 \mathrm{lb} /$ TBtu (approximately $0.053 \mu \mathrm{g} / \mathrm{dNm}^{3}$ at $3 \% \mathrm{O}_{2}$ ) for new sources. As sampled, it can be seen that EPA M29 is not able to report at this level for new sources. Although it is difficult to tell from the graph, the data show that the ME-ST-M detection limit for Cd is very near the MATS limit for new sources. The ME-ST-M method data for this data set are not valid because of the background correction, and the background levels contribute to a bias and variance (precision) that would fail a M301 validation. These data clearly show that the background for $\mathrm{Cd}$ in the original traps is significant and a problem if not reduced.

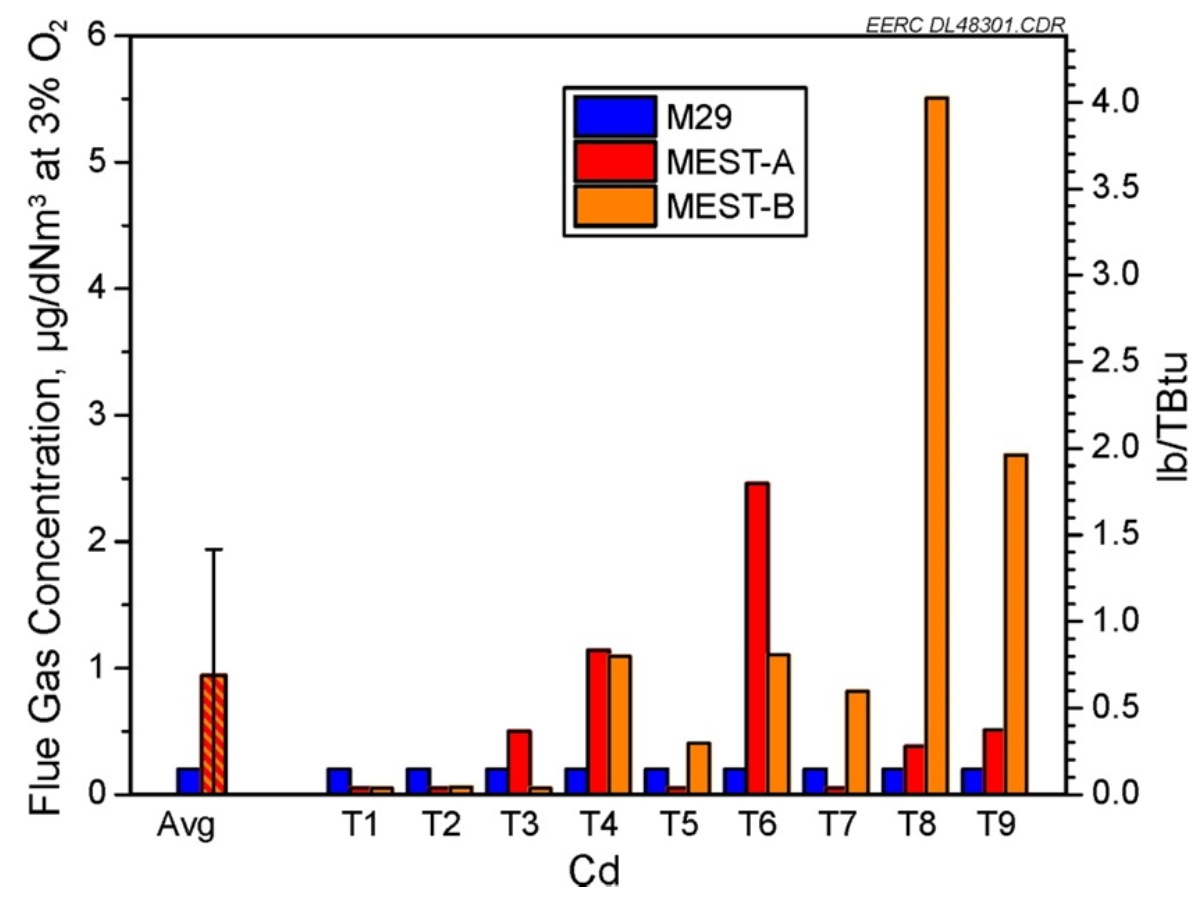

Figure C-4. Comparison of EPA M29 and ME-ST-M data for cadmium, Plant 1. 


\section{Chromium, Cr}

The Cr results for Plant 1 are shown in Figure C-5. For plants burning lignite, the MATS limits are $2.8 \mathrm{lb} /$ TBtu (approximately $3.99 \mu \mathrm{g} / \mathrm{dNm}^{3}$ at $3 \% \mathrm{O}_{2}$ ) for existing sources and $0.007 \mathrm{lb} / \mathrm{TBtu}$ (approximately $0.93 \mu \mathrm{g} / \mathrm{dNm}^{3}$ at $3 \% \mathrm{O}_{2}$ ) for new sources. It can be seen that both methods show the emission levels are below the MATS limit for the plant. From the flagging notations in the data tables of data, it is known that neither method produced valid data because of background correction. It can be seen from the graph and the data that the ME-ST-M detection limit for $\mathrm{Cr}$ is sufficiently below the MATS limit for new sources. The background levels for both methods would make a bias calculation for M301 validation difficult if not meaningless without first reducing the background levels, and the same is true for a precision comparison. These data clearly show that the background for $\mathrm{Cr}$ in the original traps is significant and a problem if not reduced. These data also show that the background for $\mathrm{Cr}$ in EPA M29 is significant and a problem if not reduced.

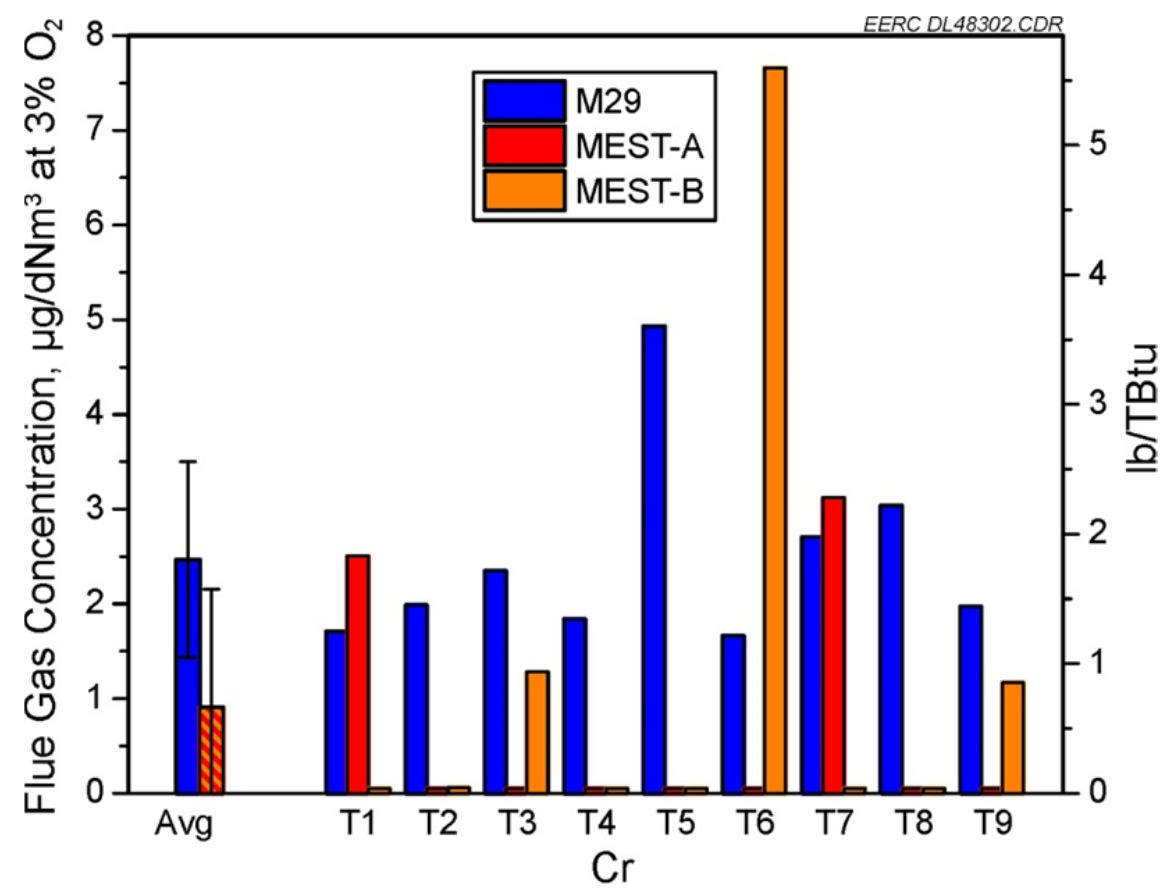

Figure C-5. Comparison of EPA M29 and ME-ST-M data for chromium, Plant 1. 


\section{Cobalt, Co}

The Co results for Plant 1 are shown in Figure C-6. The lack of error bars on the average data indicates that the data are below the detection limits. For plants burning lignite, the MATS limits are approximately $0.8 \mathrm{lb} / \mathrm{TBtu}$ (approximately $1.08 \mu \mathrm{g} / \mathrm{dNm}^{3}$ at $3 \% \mathrm{O}_{2}$ ) for existing sources and $0.002 \mathrm{lb} / \mathrm{TBtu}$ (approximately $0.27 \mu \mathrm{g} / \mathrm{dNm}^{3}$ at $3 \% \mathrm{O}_{2}$ ) for new sources. It can be seen that the EPA M29 method cannot meet the requirements for new sources and the ME-ST-M method is very near the new source limit. Both methods show the emission levels are below the MATS limit for the plant. The ME-ST-M method data for this data set are not valid because of the background correction, but the comparison of the data indicates that the alternative method is equivalent to the EPA M29 reference method since all of the data are less than values.

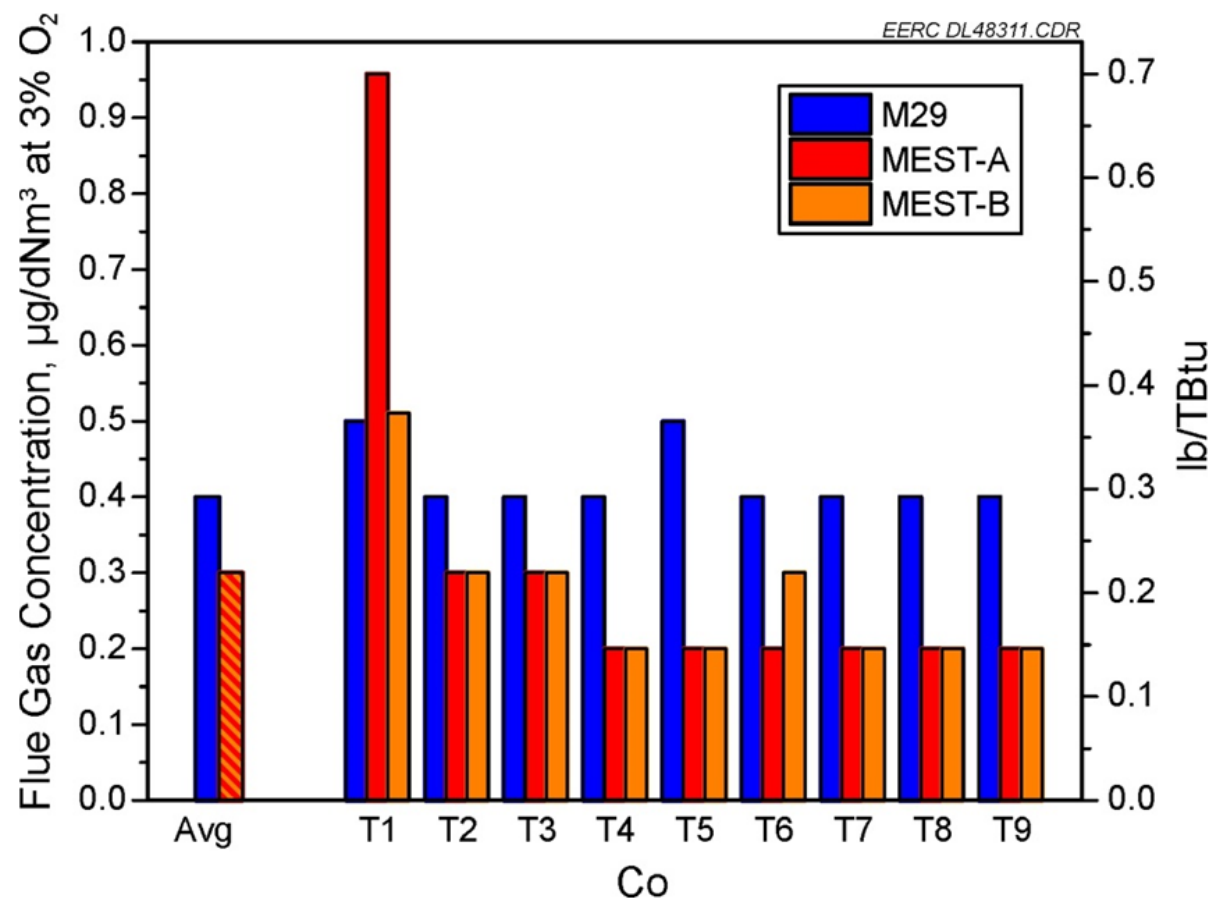

Figure C-6. Comparison of EPA M29 and ME-ST-M data for cobalt, Plant 1. 


\section{Lead, $\mathbf{P b}$}

The $\mathrm{Pb}$ results for Plant 1 are shown in Figure $\mathrm{C}-7$. For plants burning lignite, the MATS limits are $1.2 \mathrm{lb} / \mathrm{TBtu}$ (approximately $2.65 \mu \mathrm{g} / \mathrm{dNm}^{3}$ at $3 \% \mathrm{O}_{2}$ ) for both existing and new sources. It can be seen that the EPA M29 data show the emission levels are below the MATS limit for the plant. From the flagging notations in the data tables, it is known that neither method produced valid data because of background correction. It can be seen from the data that the ME$\mathrm{ST}-\mathrm{M}$ detection limit for $\mathrm{Pb}$ is sufficiently below the MATS limit. The background levels for both methods would make a comparison for M301 validation difficult if not meaningless without first reducing the background levels. These data clearly show that the background for $\mathrm{Pb}$ in the original traps is significant and a problem if not reduced. These data also show that the background for $\mathrm{Pb}$ in EPA M29 is significant and a problem if not reduced.

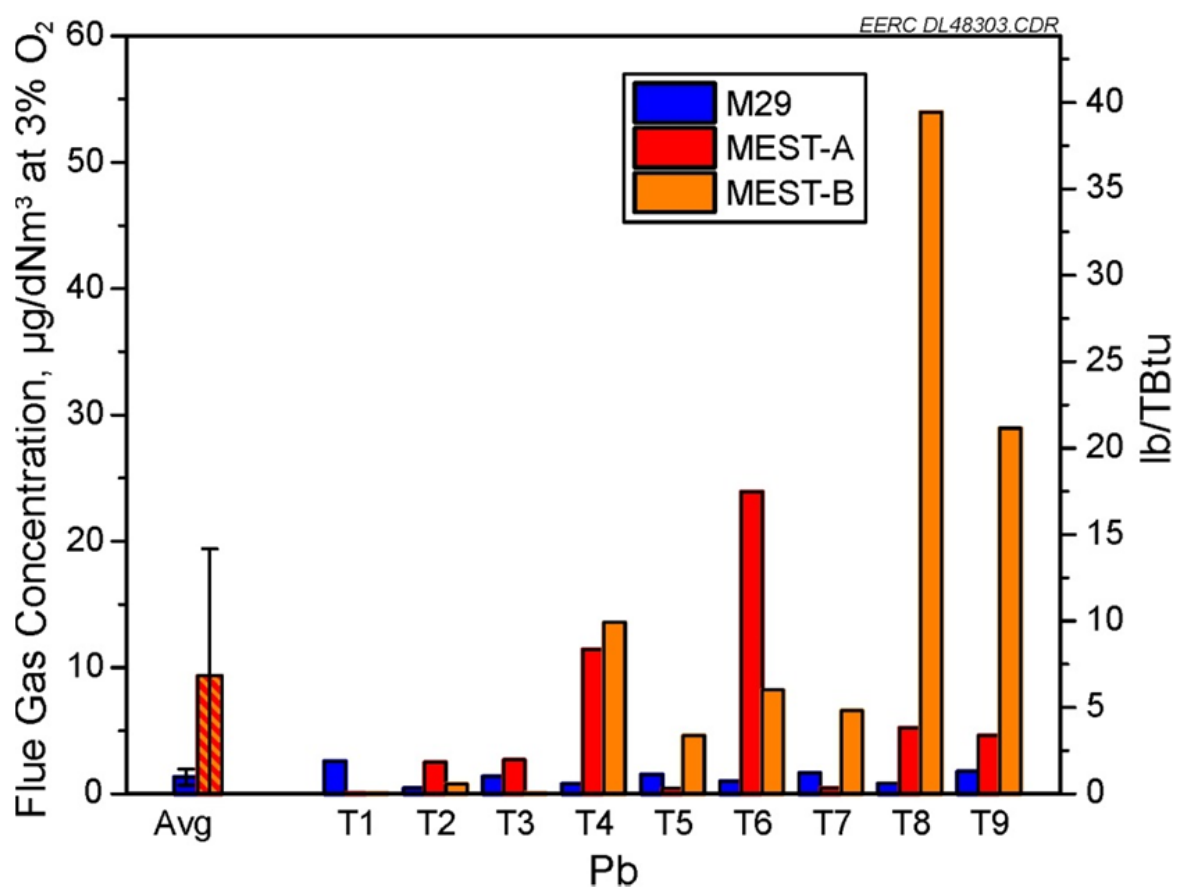

Figure C-7. Comparison of EPA M29 and ME-ST-M data for lead, Plant 1. 


\section{Manganese, Mn}

The Mn results for Plant 1 are shown in Figure C-8. For plants burning lignite, the MATS limits are $4.0 \mathrm{lb} /$ TBtu (approximately $6.63 \mu \mathrm{g} / \mathrm{dNm}^{3}$ at $3 \% \mathrm{O}_{2}$ ) for existing sources and $0.004 \mathrm{lb} / \mathrm{TBtu}$ (approximately $0.53 \mu \mathrm{g} / \mathrm{dNm}^{3}$ at $3 \% \mathrm{O}_{2}$ ) for new sources. It can be seen that the EPA M29 data show the emission levels are below the MATS limit for the plant. From the flagging notations in the data tables, it is known that neither method produced valid data because of background correction. It can be seen from the data, that the ME-ST-M detection limit for Mn is sufficiently below the MATS limit. The background levels for both methods would make a comparison for M301 validation difficult if not meaningless without first reducing the background levels. These data clearly show that the background for $\mathrm{Mn}$ in the original traps is significant and a problem if not reduced. These data also show that the background for $\mathrm{Mn}$ in EPA M29 is significant and a problem if not reduced.

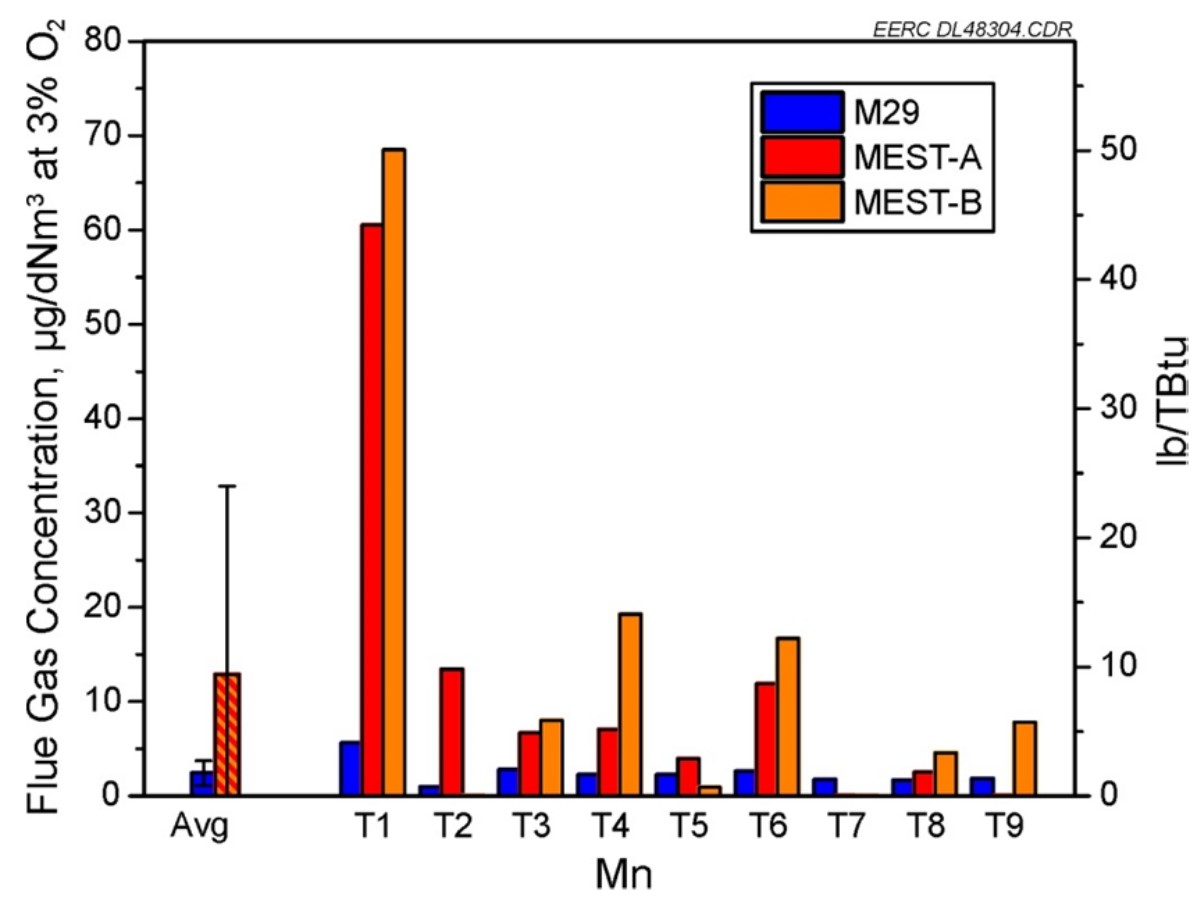

Figure C-8. Comparison of EPA M29 and ME-ST-M data for manganese, Plant 1. 


\section{Mercury, Hg}

The $\mathrm{Hg}$ results for Plant 1 are shown in Figure C-9. For plants burning lignite, the MATS limits are $4.0 \mathrm{lb} / \mathrm{TBtu}$ (approximately $5.42 \mu \mathrm{g} / \mathrm{dNm}^{3}$ at $3 \% \mathrm{O}_{2}$ ) for existing and new sources. It can be seen that both methods show that the $\mathrm{Hg}$ emissions are above the MATS limit for the plant. The ME-ST-M method data met the quality assurance/quality control (QA/QC) requirements for breakthrough $(<5 \%)$ and relative difference (RD) for the nine paired traps $(<20 \%)$. The data for each method appear consistent, but the average data, shown on the left of the graph (C-9), show a slight bias low for the ME-ST-M method as compared to the reference EPA M29 method. Although this data set is too small for a complete M301 field validation, the data was used to investigate bias and precision using a similar approach. The significance of the bias were determined with a bias analysis, and the t-statistic was calculated to be 12.00 , showing the bias to be significant at the $95 \%$ confidence level $\left(>t_{s}=2.306\right)$. The bias was then calculated using the differences between the two methods for the nine tests, with a result of $18.1 \%$, which is outside the range of $10 \%$ to be acceptable but within the range of $30 \%$, requiring correction for bias in future tests to be acceptable. It should be noted, however, that the bias may be due to flue gas sampling at different locations. The precision of the two methods was statistically compared with a modified $\mathrm{F}$ test (modified for the smaller data set) and was shown to pass. The variance of the paired trap value $\left(\mathrm{S}_{\mathrm{P}}^{2}\right)$ of 0.0179 and a variance of the EPA M29 data $\left(\mathrm{S}_{\mathrm{V}}^{2}\right)$ of 0.5952 resulted in an $\mathrm{F}$ value of 0.0301 , which is less than the one-sided $\mathrm{F}$ value of 3.179 for 9 degrees of freedom. The straightforward variance $\left(\mathrm{S}^{2} \mathrm{v}\right)$ of the ME-ST-M Hg data was 0.2882 , or $3 \%$.

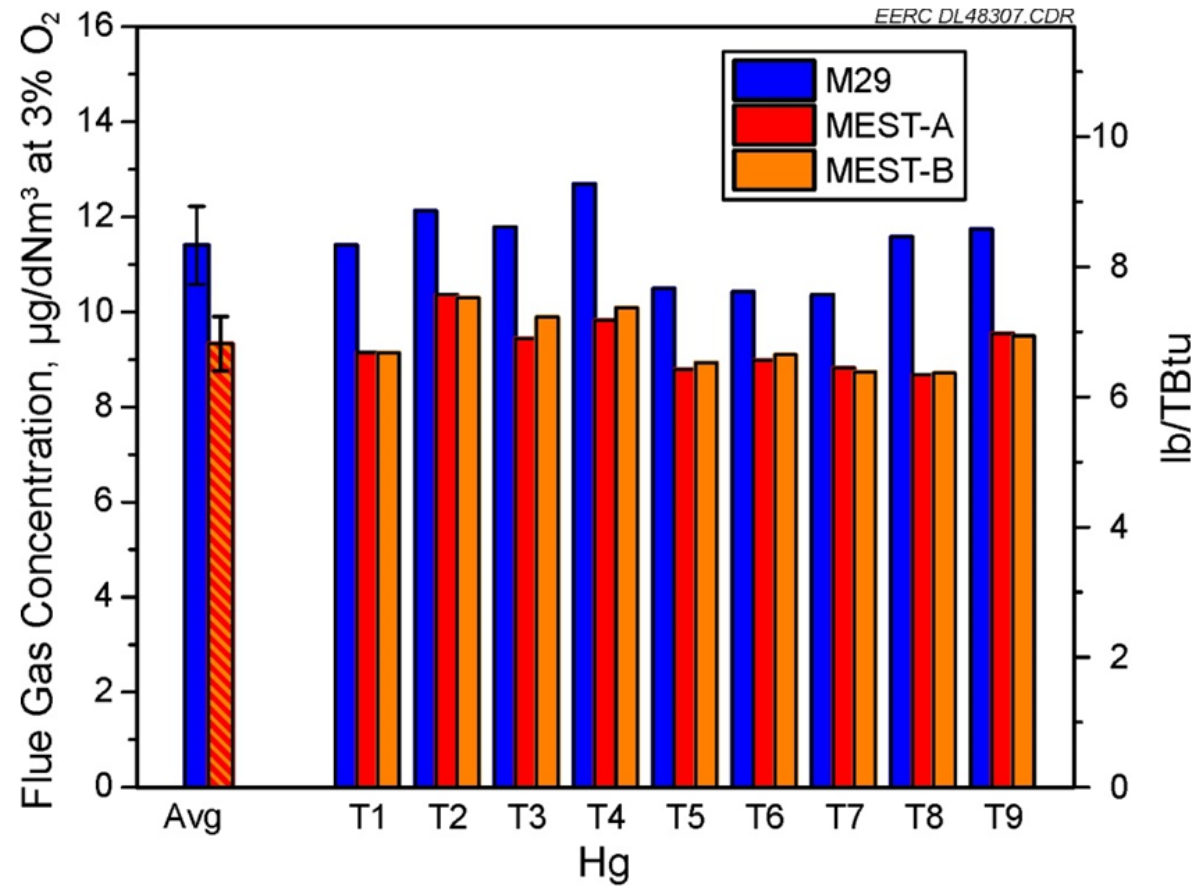

Figure C-9. Comparison of EPA M29 and ME-ST-M data for mercury, Plant 1. 


\section{Nickel, Ni}

The Ni results for Plant 1 are shown in Figure C-10. For plants burning lignite, the MATS limits are $3.5 \mathrm{lb} / \mathrm{TBtu}$ (approximately $5.31 \mu \mathrm{g} / \mathrm{dNm}^{3}$ at $3 \% \mathrm{O}_{2}$ ) for both existing and new sources. It can be seen that both methods show the emission levels are below the MATS limit for the plant. From the flagging notations in the data tables, it is known that neither method produced valid data because of background correction. It can be seen from the graph and the data that the ME-ST-M detection limit for Ni is sufficiently below the MATS limits for new sources. The background levels for both methods would make a comparison for M301 validation difficult if not meaningless without first reducing the background levels. These data clearly show that the background for $\mathrm{Ni}$ in the original traps is significant and a problem if not reduced. These data also show that the background for Ni in EPA M29 is significant and a problem if not reduced.

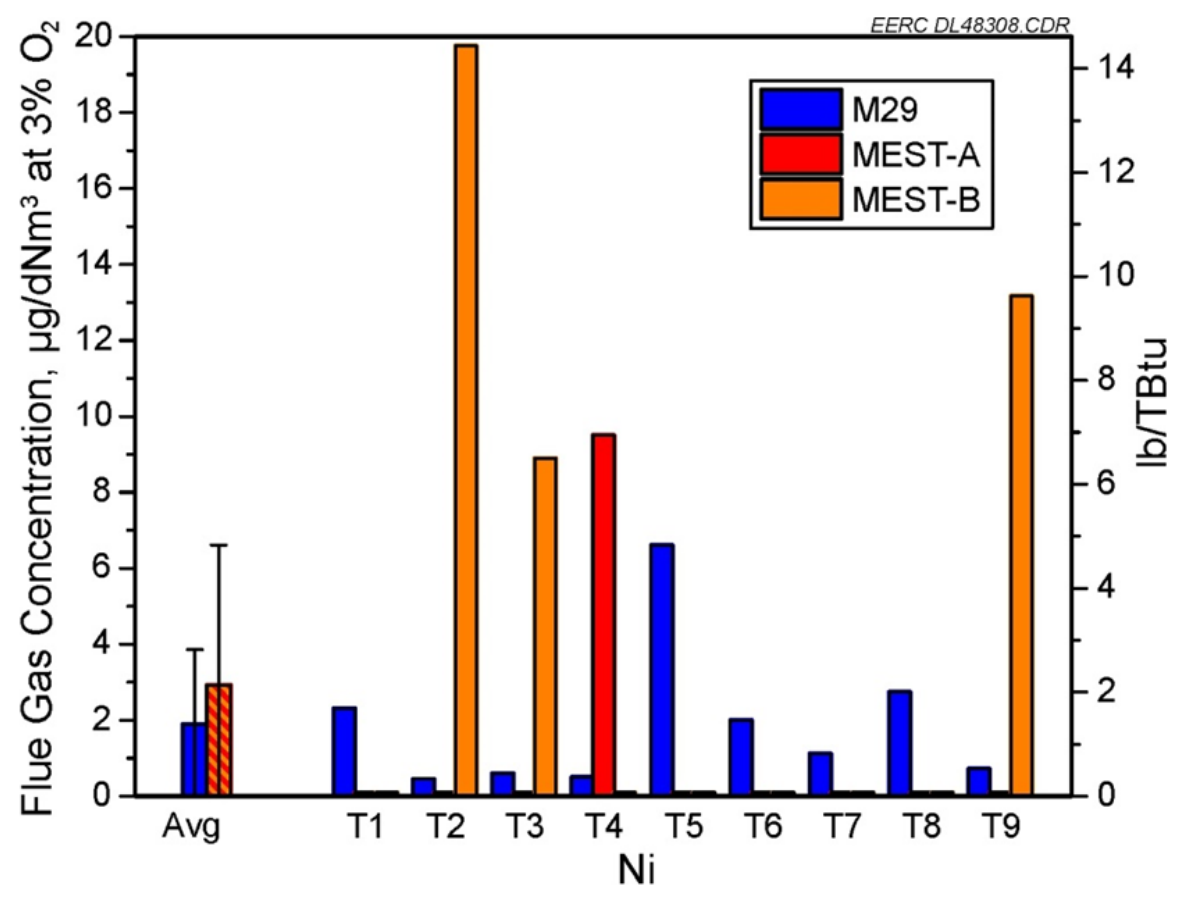

Figure C-10. Comparison of EPA M29 and ME-ST-M data for nickel, Plant 1. 


\section{Selenium, Se}

The Se results for Plant 1 are shown in Figure C-11. For plants burning lignite, the MATS limits are $5.0 \mathrm{lb} /$ TBtu (approximately $7.96 \mu \mathrm{g} / \mathrm{dNm}^{3}$ at $3 \% \mathrm{O}_{2}$ ) for existing sources and $0.05 \mathrm{lb} / \mathrm{TBtu}$ (approximately $6.67 \mu \mathrm{g} / \mathrm{dNm}^{3}$ at $3 \% \mathrm{O}_{2}$ ) for new sources. The data for both methods appear to trend across the set of tests which covered 3 days, indicating that the flue gas concentration was changing over time. The trending in the figure shows that most of the variability in the Se concentrations for the set of data was due to changing flue gas concentrations. The average data, shown on the left of the graph (C-11), shows a comparable standard deviation for the set of data, with a slight bias low for the ME-ST-M method as compared to the reference EPA M29 method. It can be seen that both methods show the emission levels are below the MATS limit for the plant. From the flagging notations in the data tables, it is known that EPA M29 did not produce valid data because of background correction. It can be seen from the data that both methods have detection limits for Se sufficiently below the MATS limits. The ME-ST-M method data met the QA/QC requirements for breakthrough $(<5 \%)$ for 16 of the 18 traps, with failures for T2-B (breakthrough of 18\%) and for T3-A (breakthrough of $8 \%$ ). It should be noted that the levels of Se in the flue gas require a no detect for the second trap for the breakthrough to be acceptable as the detection limit is approximately $5 \%$ of the total mass of Se collected. Because of the low values and the relatively minor breakthrough, the data were deemed acceptable for comparative purposes and were not thrown out of the data set. The MEST-M method data met the QA/QC requirements for RD for eight of the nine paired traps $(<20 \%)$, with a failure for T5, with a RD of $22 \%$. Again because of the low values, this data point was not thrown out of the data set for comparative purposes.

Although this data set is too small for a complete M301 field validation, the data were used to investigate bias and precision using a similar approach. The significance of the bias was determined with a bias analysis, and the t-statistic was calculated to be 3.15, showing the bias to be significant at the $95 \%$ confidence level $\left(>t_{\mathrm{s}}=2.37\right)$. The bias was then calculated using the differences between the two methods for the nine tests, with a result of $27.7 \%$, which is outside the range of $10 \%$ to be acceptable but within the range of $30 \%$, requiring correction for bias in future tests to be acceptable. The precision of the two methods was statistically compared with a modified $\mathrm{F}$ test (modified for the smaller data set) and was shown to pass. The variance of the paired trap value $\left(\mathrm{S}_{\mathrm{P}}^{2}\right)$ of 0.292 and a variance of the EPA M29 data $\left(\mathrm{S}_{\mathrm{V}}^{2}\right)$ of 2.283 , resulted in an $F$ value of 0.1279 , which is less than the one-sided $F$ value of 3.179 for 9 degrees of freedom.

The low values for Se in the flue gas make this unit particularly challenging for sampling, and these data show that the background for Se in EPA M29 is significant and a problem if not reduced. The statistical calculations for bias and precision, comparing the methods, were shown to be acceptable with this data set and would presumably improve with valid EPA M29 data. 


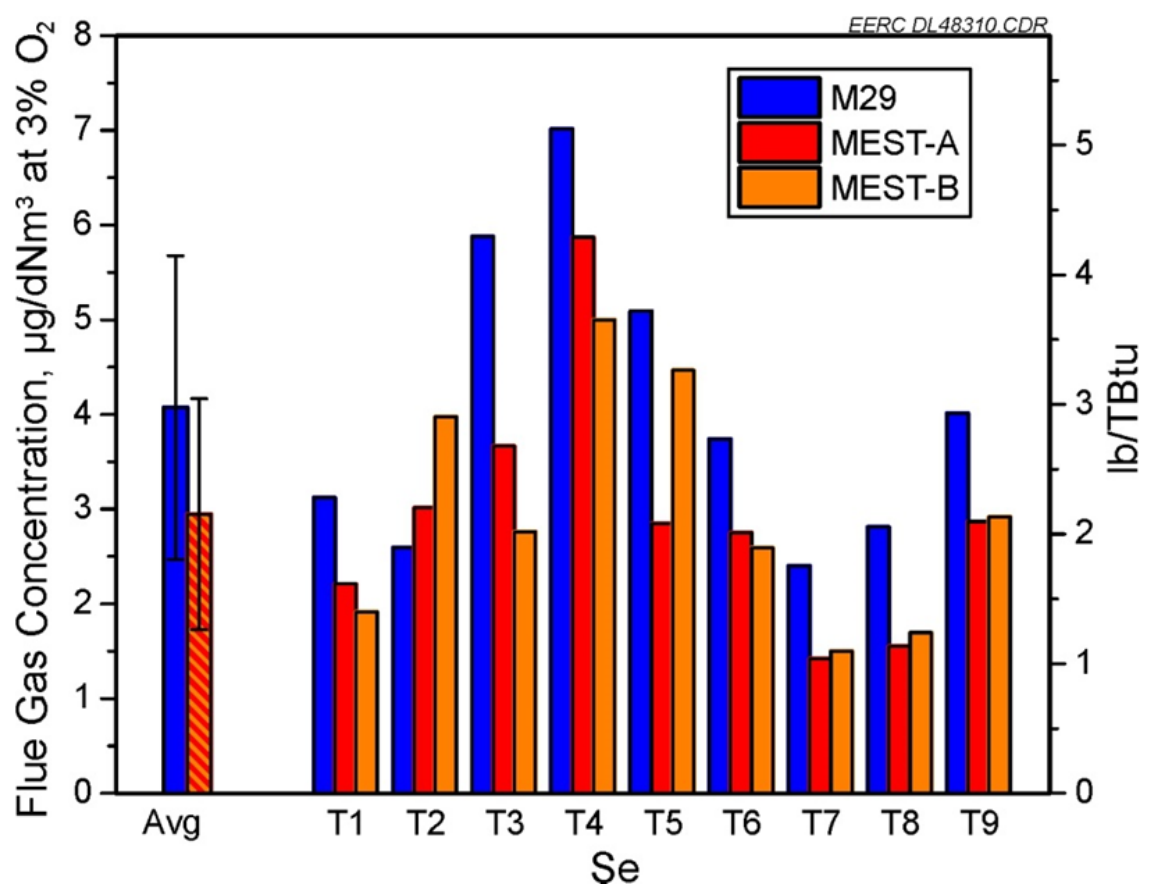

Figure C-11. Comparison of EPA M29 and ME-ST-M data for selenium, Plant 1. 


\section{POWER PLANT 2}

\section{Antimony, Sb}

The $\mathrm{Sb}$ results for Plant 2 are shown in Figure $\mathrm{C}-12$. The lack of error bars on the average EPA M29 data indicates that the data are below the detection limit. The MATS limit is $0.8 \mathrm{lb} / \mathrm{TBtu}$ (approximately $1.08 \mu \mathrm{g} / \mathrm{dNm}^{3}$ at $3 \% \mathrm{O}_{2}$ ) for plants burning lignite for both new and existing sources. As sampled, it can be seen that EPA M29 is not able to report at this level, but the ME-ST-M data show that the Sb emissions are below the MATS limit for the unit. The MEST-M method data met all the QA/QC requirements for breakthrough $(<5 \%)$ and RD $(<20 \%)$ and are equivalent to the EPA M29 data, but a detailed comparison of the data for bias and precision is not feasible since the EPA M29 reference method data are all less than values.

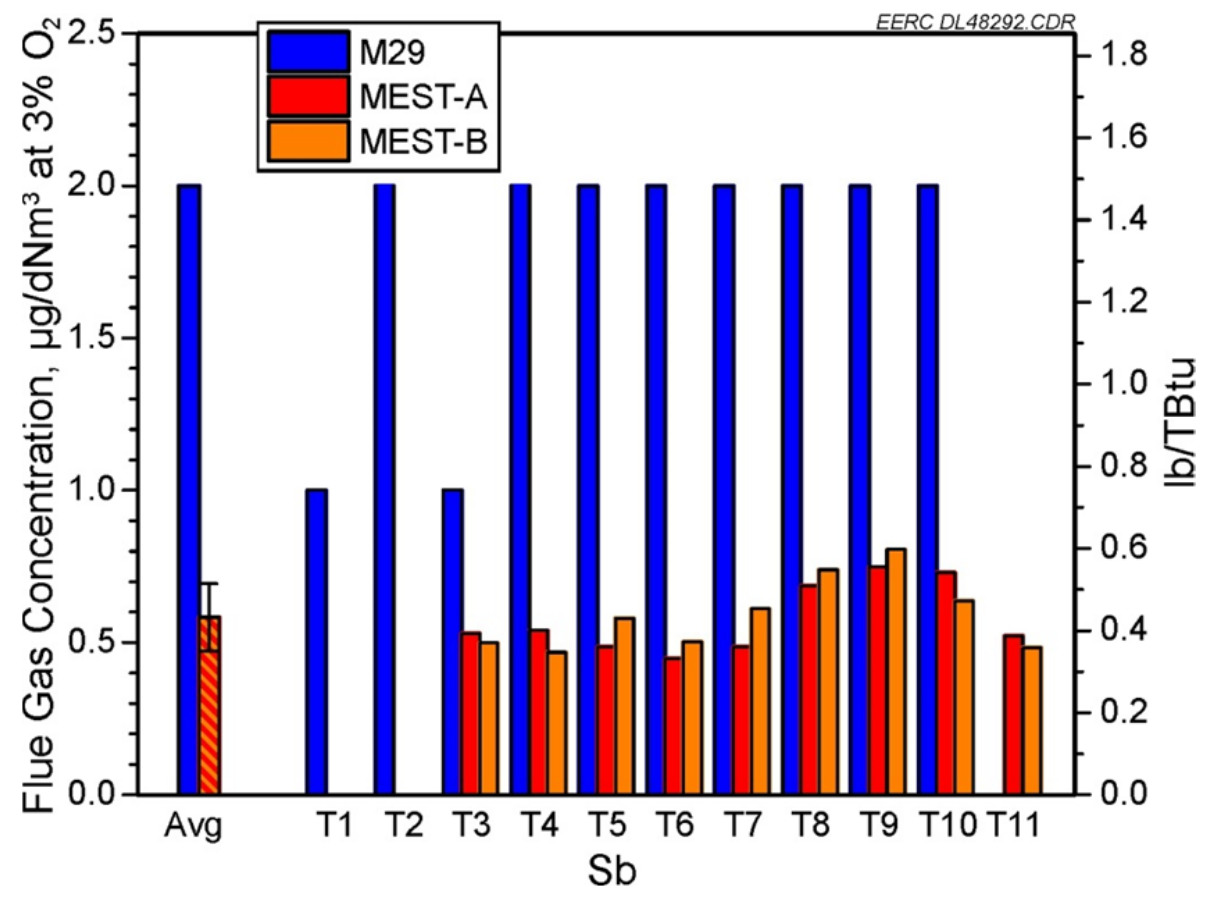

Figure C-12. Comparison of EPA M29 and ME-ST-M data for antimony, Plant 2. 


\section{Arsenic, As}

The As results for Plant 2 are shown in Figure C-13. For plants burning lignite, the MATS limits are $1.1 \mathrm{lb} /$ TBtu (approximately $2.65 \mu \mathrm{g} / \mathrm{dNm}^{3}$ at $3 \% \mathrm{O}_{2}$ ) for existing sources and $0.003 \mathrm{lb} / \mathrm{TBtu}$ (approximately $0.40 \mu \mathrm{g} / \mathrm{dNm}^{3}$ at $3 \% \mathrm{O}_{2}$ ) for new sources. It can be seen that both methods show that the As emissions are above the MATS limit for the unit. The ME-ST-M method data met the QA/QC requirements for breakthrough $(<5 \%)$ and $\mathrm{RD}$ for the nine paired traps $(<20 \%)$. The data for each method appear consistent, but the average data, shown on the left of the graph, show a slight bias low for the ME-ST-M method as compared to the reference EPA M29 method.

Although this data set is too small for a complete M301 field validation, the data were used to investigate bias and precision using a similar approach utilizing the data set for common tests T3 through T10. The significance of the bias was determined with a bias analysis, and the tstatistic was calculated to be 4.84 , showing the bias to be significant at the $95 \%$ confidence level $\left(>t_{s}=2.365\right)$. The bias was then calculated using the differences between the two methods for the eight tests, with a result of $22.9 \%$, which is outside the range of $10 \%$ to be acceptable but within the range of $30 \%$, requiring correction for bias in future tests to be acceptable. The precision of the two methods was statistically compared with a modified $F$ test (modified for the smaller data set) and was shown to pass. The variance of the paired trap value $\left(\mathrm{S}_{\mathrm{P}}^{2}\right)$ of 1.7166 and a variance of the EPA M29 data $\left(\mathrm{S}^{2}\right.$ v) of 2.5548 resulted in an F value of 0.6719 , which is less than the onesided $\mathrm{F}$ value of 3.4381 for 8 degrees of freedom.

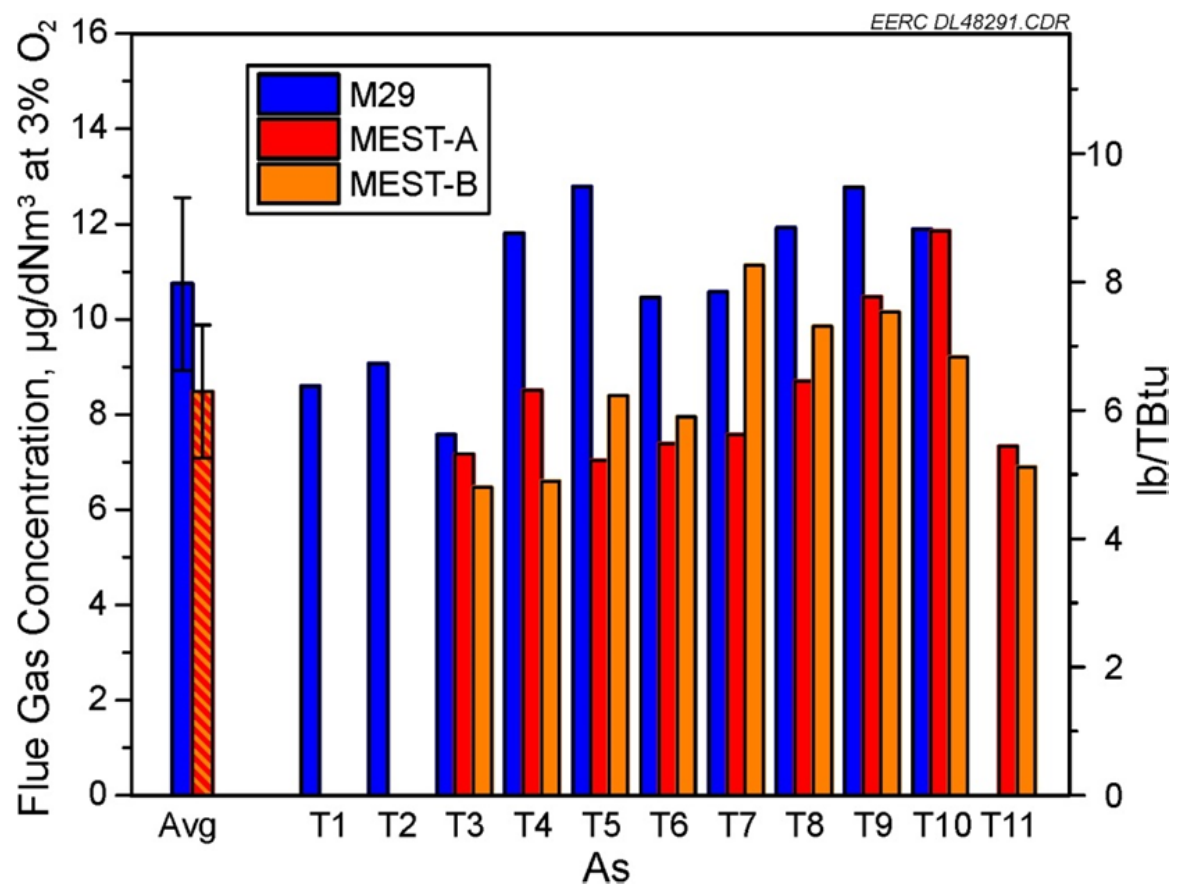

Figure C-13. Comparison of EPA M29 and ME-ST-M data for arsenic, Plant 2. 


\section{Beryllium, Be}

The Be results for Plant 2 are shown in Figure C-14. The lack of error bars on the EPA M29 average data indicates that the data are below the detection limit. For plants burning lignite, the MATS limits are $0.2 \mathrm{lb} / \mathrm{TBtu}$ (approximately $0.27 \mu \mathrm{g} / \mathrm{dNm}^{3}$ at $3 \% \mathrm{O}_{2}$ ) for existing sources and $0.0006 \mathrm{lb} /$ TBtu (approximately $0.073 \mu \mathrm{g} / \mathrm{dNm}^{3}$ at $3 \% \mathrm{O}_{2}$ ) for new sources. It can be seen that both methods show that the Be emissions are below the MATS limit for the unit. The MEST-M method data for this data set are not valid because of the background correction, but the comparison of the data indicates that the alternative method is equivalent to the EPA M29 reference method since all of the data are less than values. The ME-ST-M shows a much lower detection limit than M29.

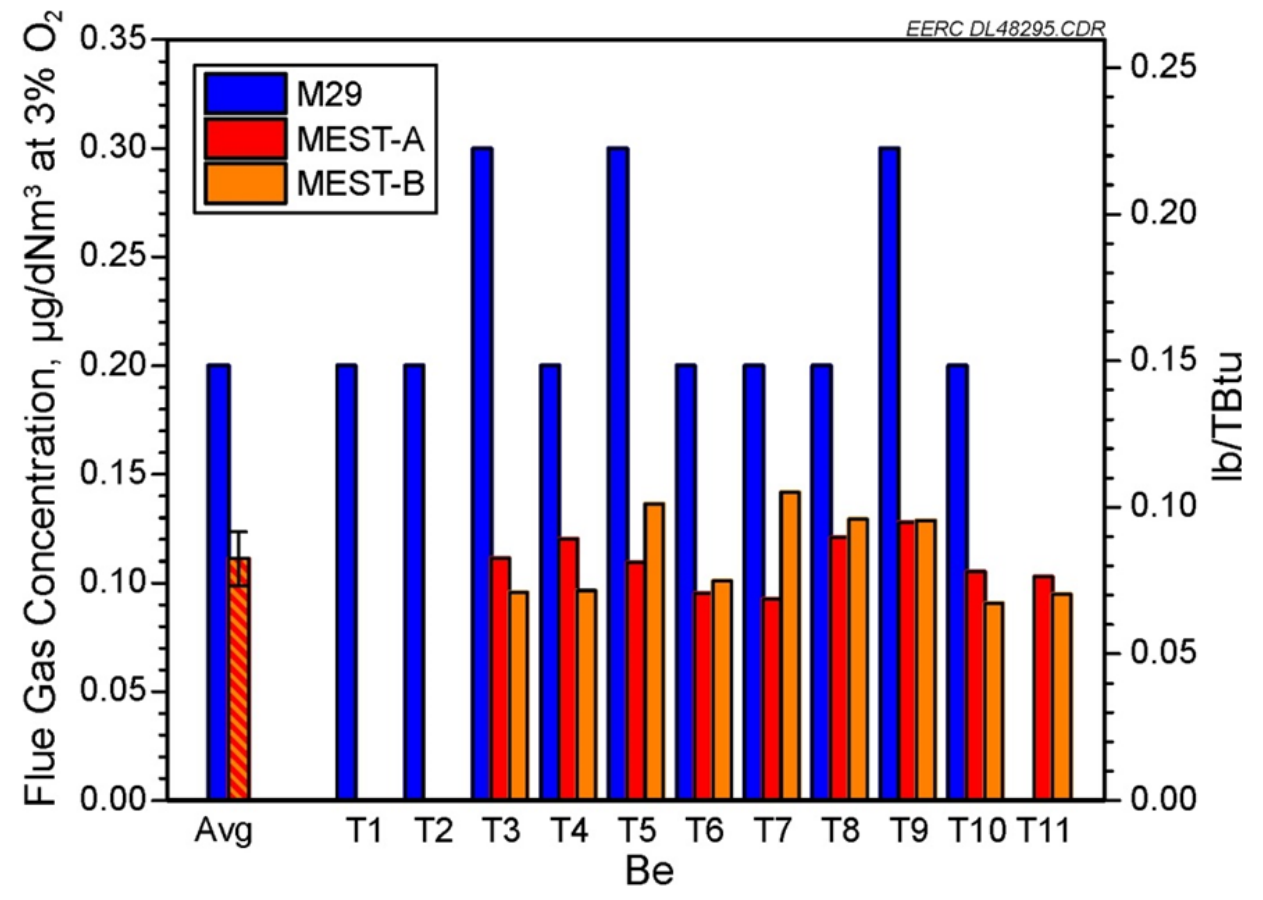

Figure C-14. Comparison of EPA M29 and ME-ST-M data for beryllium, Plant 2. 


\section{Cadmium, Cd}

The Cd results for Plant 2 are shown in Figure C-15. The lack of error bars for the EPA M29 average data indicates that the data are below the detection limit. For plants burning lignite, the MATS limits are $0.3 \mathrm{lb} / \mathrm{TBtu}$ (approximately $0.41 \mu \mathrm{g} / \mathrm{dNm}^{3}$ at $3 \% \mathrm{O}_{2}$ ) for existing sources and $0.0004 \mathrm{lb} /$ TBtu (approximately $0.053 \mu \mathrm{g} / \mathrm{dNm}^{3}$ at $3 \% \mathrm{O}_{2}$ ) for new sources. It can be seen that the EPA M29 data show the Cd emissions are below the MATS limit for the unit. The MEST-M method data for this data set is not valid because of the background correction, and the background levels contribute to a bias and variance (precision) that would fail a M301 validation. These data clearly show that the background for $\mathrm{Cd}$ is variable, indicating an external source of contamination. At the levels required by the regulations, the current background is significant, and further reduction of the background is required to be able to utilize the method at these levels.

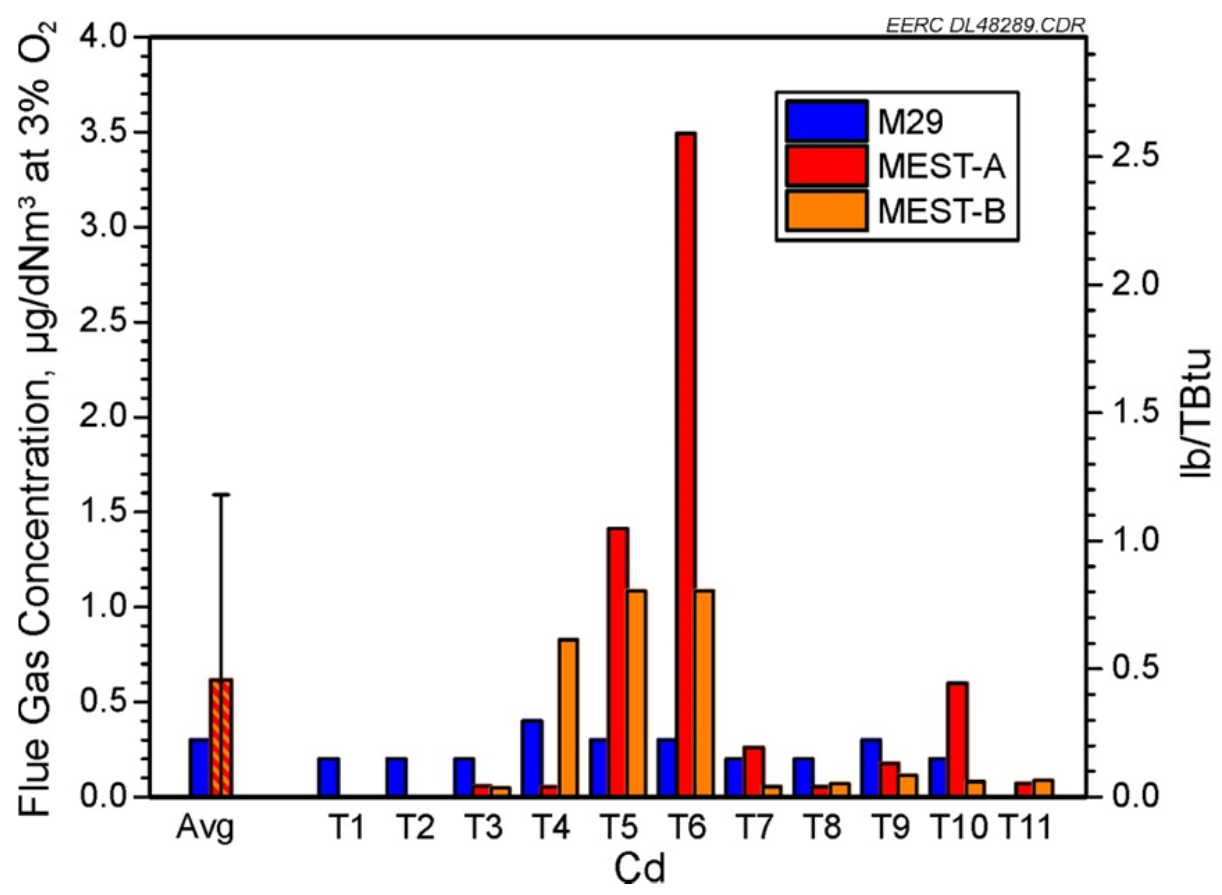

Figure C-15. Comparison of EPA M29 and ME-ST-M data for cadmium, Plant 2. 


\section{Chromium, $\mathrm{Cr}$}

The $\mathrm{Cr}$ results for Plant 2 are shown in Figure C-16. For plants burning lignite, the MATS limits are $2.8 \mathrm{lb} /$ TBtu (approximately $3.99 \mu \mathrm{g} / \mathrm{dNm}^{3}$ at $3 \% \mathrm{O}_{2}$ ) for existing sources and $0.007 \mathrm{lb} / \mathrm{TBtu}$ (approximately $0.93 \mu \mathrm{g} / \mathrm{dNm}^{3}$ at $3 \% \mathrm{O}_{2}$ ) for new sources. It can be seen that both methods show the emission levels are near the MATS limit for the plant. From the flagging notations in data tables, it is known that neither method produced valid data because of background correction. The background levels for both methods would make a comparison for M301 validation difficult if not meaningless without first reducing the background levels. These data clearly show that the background for $\mathrm{Cr}$ is variable, indicating an external source of contamination. At the levels required by the regulations, the current background is significant, and further reduction of the background is required to be able to utilize either of these methods at these levels.

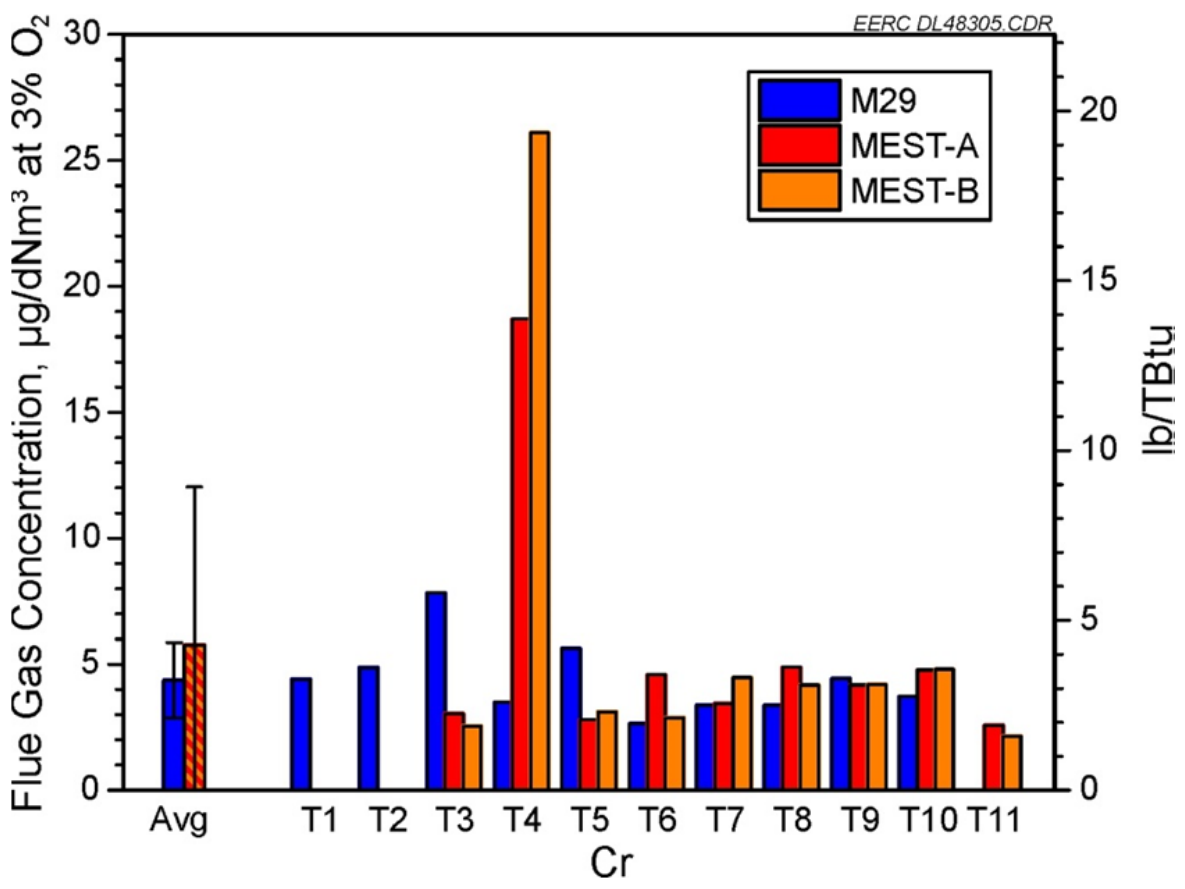

Figure C-16. Comparison of EPA M29 and ME-ST-M data for chromium, Plant 2. 


\section{Cobalt, Co}

The Co results for Plant 2 are shown in Figure C-17. For plants burning lignite, the MATS limits are $0.8 \mathrm{lb} /$ TBtu (approximately $1.08 \mu \mathrm{g} / \mathrm{dNm}^{3}$ at $3 \% \mathrm{O}_{2}$ ) for existing sources and $0.002 \mathrm{lb} / \mathrm{TBtu}$ (approximately $0.27 \mu \mathrm{g} / \mathrm{dNm}^{3}$ at $3 \% \mathrm{O}_{2}$ ) for new sources. Both methods show the emission levels are above the MATS limit for the plant. The ME-ST-M method data met the QA/QC requirements for breakthrough $(<5 \%)$ for 17 of the 18 traps, with the single failure on Trap T10-A (breakthrough 22\%). The QA/QC requirements for RD was met for all of the nine paired traps $(<20 \%)$. The data for each method appear consistent, with the exception of the EPA M29 data for T3. The average data, shown on the left of the graph, also appear comparable for the two methods. The EPA M29 data for T3 were removed from the statistical evaluation via the student t-test. Although this data set is too small for a complete M301 field validation, the data were used to investigate bias and precision using a similar approach utilizing the data set for common tests T4 through T10. The significance of the bias was determined with a bias analysis, and the t-statistic was calculated to be 0.32 , showing the bias to be insignificant at the $95 \%$ confidence level $\left(>t_{s}=2.447\right)$. The precision of the two methods was statistically compared with a modified $F$ test (modified for the smaller data set) and was shown to pass. The variance of the paired trap value $\left(\mathrm{S}_{\mathrm{P}}^{2}\right)$ of 0.0078 and a variance of the EPA M29 data $\left(\mathrm{S}^{2}{ }_{\mathrm{V}}\right)$ of 0.0057 resulted in an $F$ value of 1.3691, which is less than the one-sided $F$ value of 3.7870 for 7 degrees of freedom.

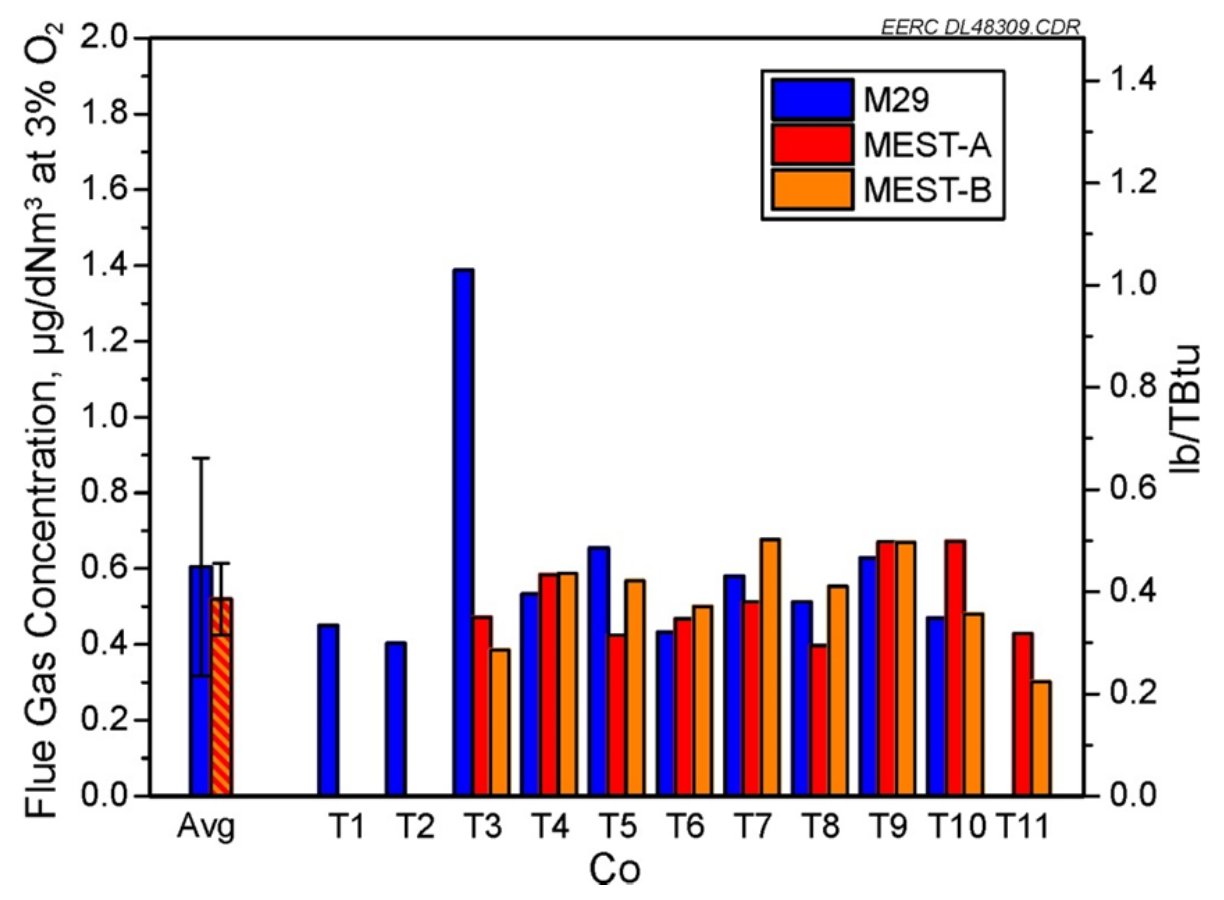

Figure C-17. Comparison of EPA M29 and ME-ST-M data for cobalt, Plant 2. 


\section{Lead, $\mathbf{P b}$}

The $\mathrm{Pb}$ results for Plant 2 are shown in Figure $\mathrm{C}-18$. For plants burning lignite, the MATS limits are $1.2 \mathrm{lb} / \mathrm{TBtu}$ (approximately $2.65 \mu \mathrm{g} / \mathrm{dNm}^{3}$ at $3 \% \mathrm{O}_{2}$ ) for both existing and new sources. It can be seen that both methods show the emission levels are above the MATS limit for the plant. From the flagging notations in the data tables, it is known that the ME-ST-M method did not produce valid data because of background correction. The average data, shown on the left of the graph, show significant variability for both methods. The ME-ST-M method data for this data set are not valid because of the background correction, and the background levels contribute to a bias and variance (precision) that would fail a M301 validation. The ME-ST-M method data failed the QA/QC requirements for breakthrough $(<5 \%)$ for ten of the 18 traps. The ME-ST-M method data met the QA/QC requirements for RD for seven of the nine paired traps $(<20 \%)$. These data clearly show that the background for $\mathrm{Pb}$ is variable, indicating an external source of contamination. At the levels required by the regulations, the current background is significant, and further reduction of the background is required to be able to utilize the method at these levels.

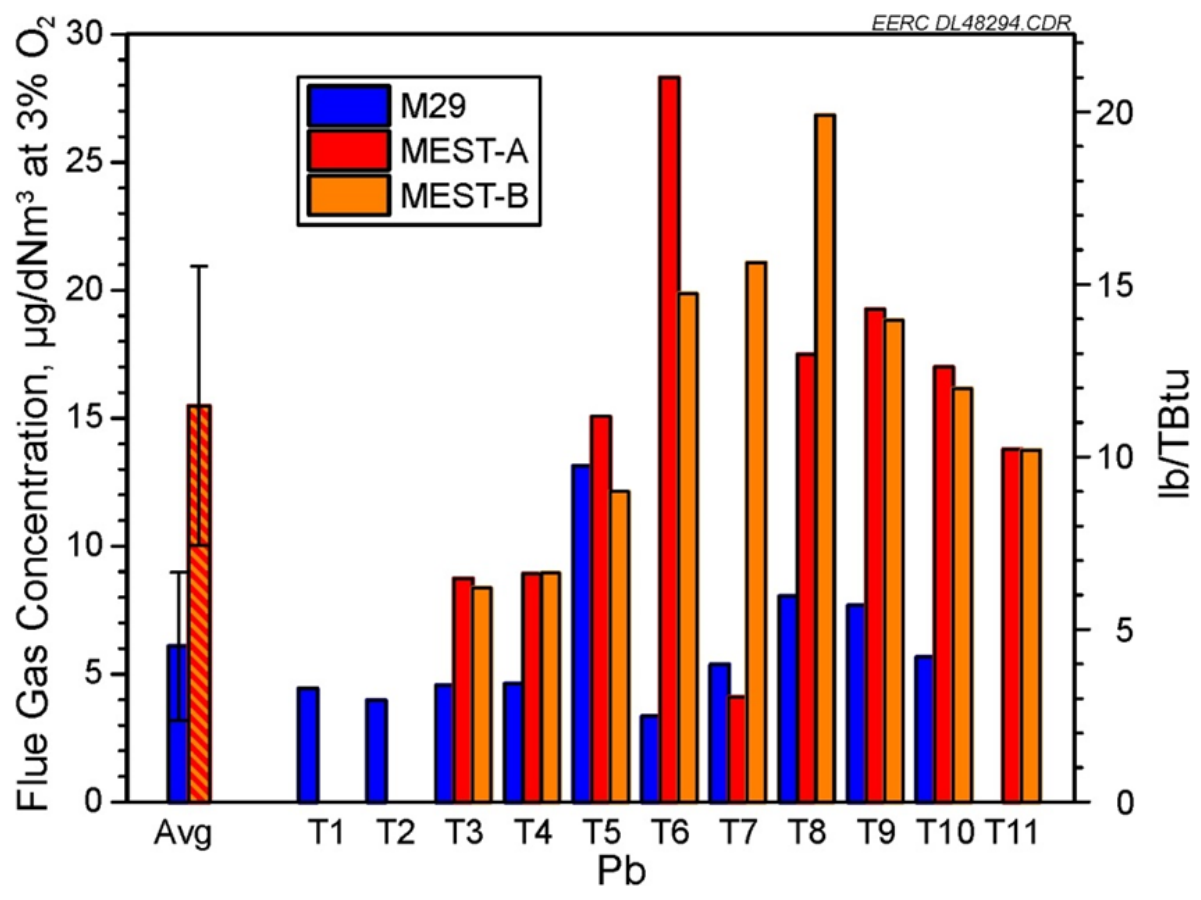

Figure C-18. Comparison of EPA M29 and ME-ST-M data for lead, Plant 2. 


\section{Manganese, Mn}

The Mn results for Plant 2 are shown in Figure C-19. For plants burning lignite, the MATS limits are $4.0 \mathrm{lb} /$ TBtu (approximately $6.63 \mu \mathrm{g} / \mathrm{dNm}^{3}$ at $3 \% \mathrm{O}_{2}$ ) for existing sources and $0.004 \mathrm{lb} / \mathrm{TBtu}$ (approximately $0.53 \mu \mathrm{g} / \mathrm{dNm}^{3}$ at $3 \% \mathrm{O}_{2}$ ) for new sources. It can be seen that the data for both methods show that the emission levels are above the MATS limit for the unit. From the flagging notations in the data tables, it is known that neither method produced valid data because of background correction. The background levels for both methods would make a comparison for M301 validation difficult if not meaningless without first reducing the background levels. These data clearly show that the background for $\mathrm{Mn}$ is variable, indicating an external source of contamination. At the levels required by the regulations, the current background is significant for both methods, and further reduction of the background is required to be able to utilize either of these methods at these levels.

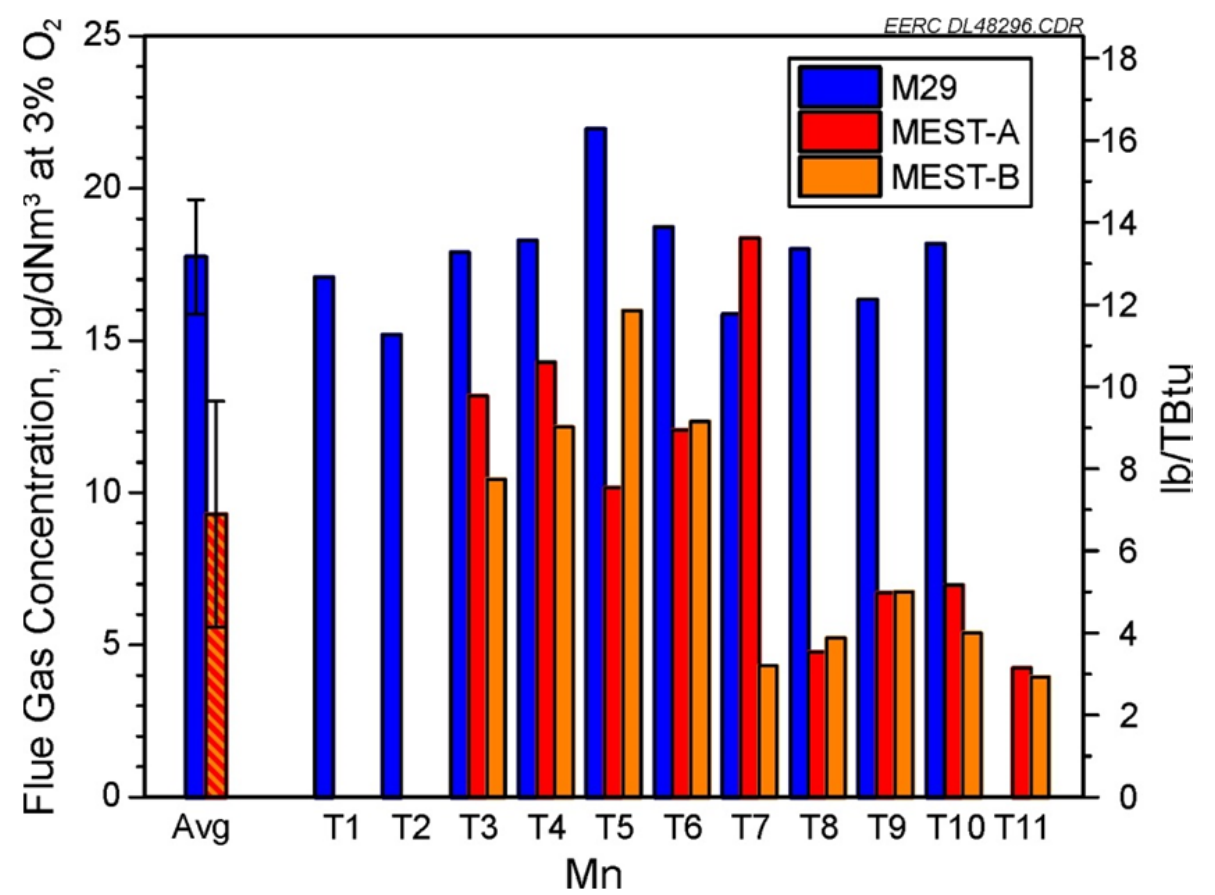

Figure C-19. Comparison of EPA M29 and ME-ST-M data for manganese, Plant 2. 


\section{Mercury, Hg}

The $\mathrm{Hg}$ results for Plant 2 are shown in Figure C-20. For plants burning lignite, the MATS limits are $4.0 \mathrm{lb} / \mathrm{TBtu}$ (approximately $5.42 \mu \mathrm{g} / \mathrm{dNm}^{3}$ at $3 \% \mathrm{O}_{2}$ ) for existing and new sources. It can be seen that both methods show that the $\mathrm{Hg}$ emissions are above the MATS limit for the unit. The ME-ST-M method data met the QA/QC requirements for breakthrough $(<5 \%)$ and RD for the nine paired traps $(<20 \%)$. The data for each method appear consistent, and the average data, shown on the left of the graph, show a comparable average for the ME-ST-M method as compared to the reference EPA M29. Although this data set is too small for a complete M301 field validation, the data were used to investigate bias and precision using a similar approach. The significance of the bias was determined with a bias analysis, and the t-statistic was calculated to be 9.13 , showing the bias to be significant at the $95 \%$ confidence level $\left(>t_{\mathrm{s}}=\right.$ 2.365). The bias was then calculated using the differences between the two methods for the nine tests, with a result of $8.9 \%$, which is within the range of $10 \%$ to be acceptable without adjustment for bias. The precision of the two methods was statistically compared with a modified F test (modified for the smaller data set) and was shown to pass. The variance of the paired trap value $\left(\mathrm{S}_{\mathrm{P}}^{2}\right)$ of 0.0831 and a variance of the EPA M29 data $\left(\mathrm{S}_{\mathrm{V}}^{2}\right)$ of 0.8321 resulted in an $\mathrm{F}$ value of 0.0999 , which is less than the one-sided $\mathrm{F}$ value of 3.4381 for 8 degrees of freedom.

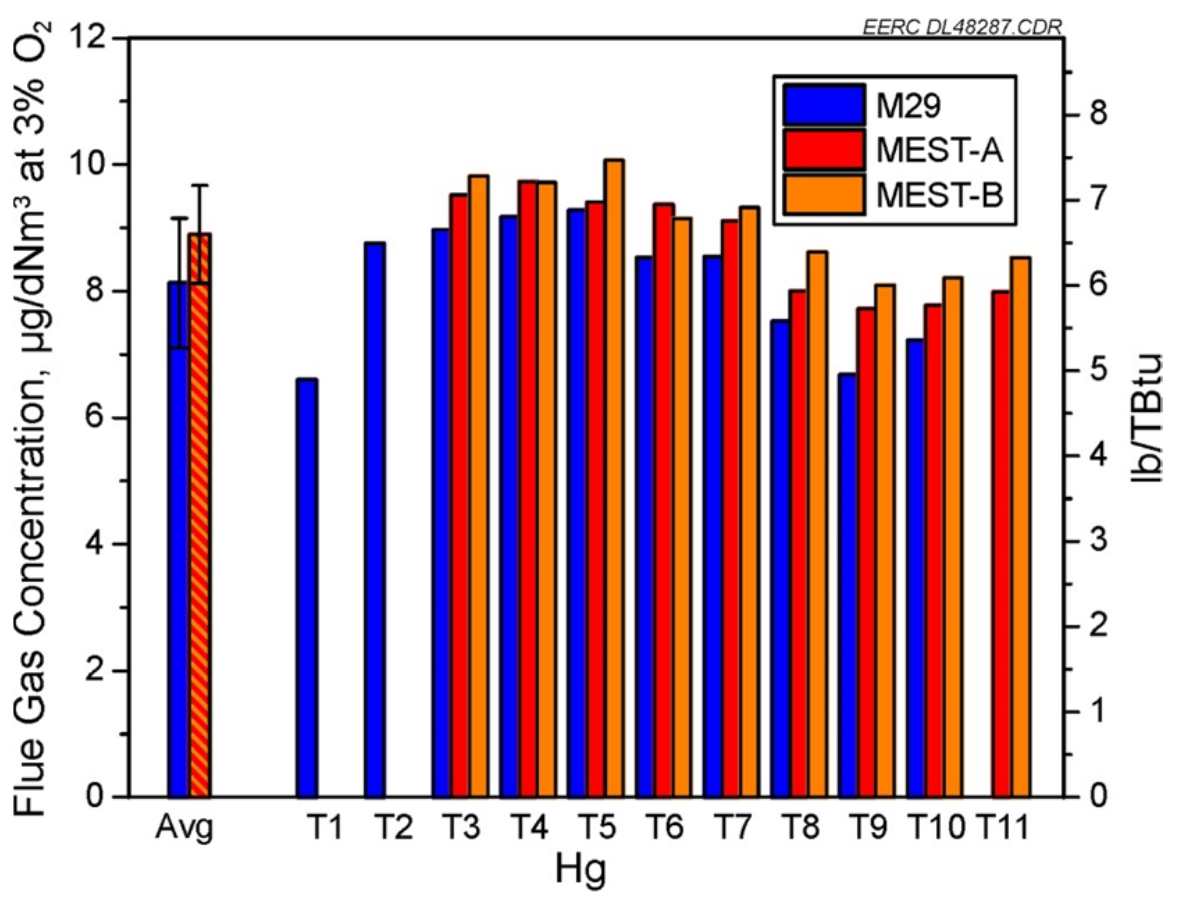

Figure C-20. Comparison of EPA M29 and ME-S-M data for mercury, Plant 2. 


\section{Nickel, Ni}

The Ni results for Plant 2 are shown in Figure C-21. For plants burning lignite, the MATS limits are $3.5 \mathrm{lb} / \mathrm{TBtu}$ (approximately $5.31 \mu \mathrm{g} / \mathrm{dNm}^{3}$ at $3 \% \mathrm{O}_{2}$ ) for both existing and new sources. It can be seen that both methods show the emission levels are below the MATS limit for the plant. From the flagging notations in the data tables, it is known that neither method produced valid data because of background correction. The background levels for both methods would make a comparison for M301 validation difficult if not meaningless without first reducing the background levels. At the levels required by the regulations, the current background is significant for both methods, and further reduction of the background is required to be able to utilize either of these methods at these levels.

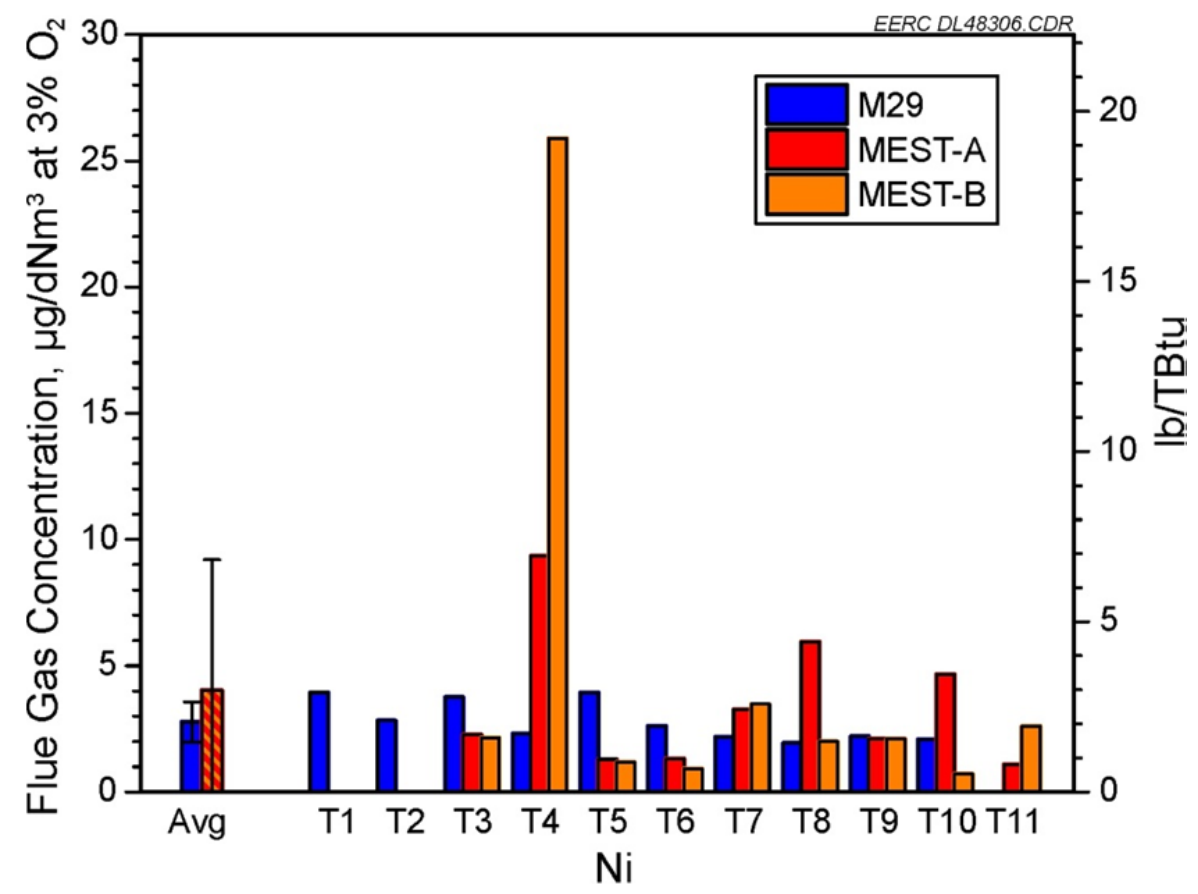

Figure C-21. Comparison of EPA M29 and ME-ST-M data for nickel, Plant 2. 


\section{Selenium, Se}

The Se results for Plant 2 are shown in Figure C-22. For plants burning lignite, the MATS limits are $5.0 \mathrm{lb} /$ TBtu (approximately $7.96 \mu \mathrm{g} / \mathrm{dNm}^{3}$ at $3 \% \mathrm{O}_{2}$ ) for existing sources and $0.05 \mathrm{lb} /$ TBtu (approximately $6.67 \mu \mathrm{g} / \mathrm{dNm}^{3}$ at $3 \% \mathrm{O}_{2}$ ) for new sources. The data for both methods show that the emissions are above the MATS limit for the unit. The average data, shown on the left of the graph, show significant variability for EPA M29 as well as a significant difference between the methods. The ME-ST-M method data met all the QA/QC requirements for breakthrough $(<5 \%)$ and for $\mathrm{RD}$ of the nine paired traps $(<20 \%)$. Although this data set is too small for a complete M301 field validation, the data were used to investigate bias and precision using a similar approach. The significance of the bias was determined with a bias analysis, and the t-statistic was calculated to be 2.98 , showing the bias to be significant at the $95 \%$ confidence level $\left(>t_{\mathrm{s}}=2.365\right)$. The bias was then calculated using the differences between the two methods for the eight tests, with a result of $56.5 \%$, which is outside the range of $10 \%$ to be acceptable and outside the range of $30 \%$, making the method unacceptable as compared to the EPA M29 reference method. The precision of the two methods was statistically compared with a modified F test (modified for the smaller data set) and was shown to pass. The variance of the paired trap value $\left(\mathrm{S}_{\mathrm{P}}^{2}\right)$ of 0.9402 and a variance of the EPA M29 data $\left(\mathrm{S}_{\mathrm{V}}^{2}\right)$ of 92.47 resulted in an F value of 0.0102 , which is less than the one-sided $F$ value of 3.4381 for 8 degrees of freedom. The straightforward variance $\left(\mathrm{S}_{\mathrm{v}}^{2}\right)$ of the ME-ST-M Se data was 1.337 , or $16 \%$.

These data show that the variability for Se in EPA M29 is significant and a problem if not reduced. The statistical calculations for bias and precision, comparing the methods, were shown to be unacceptable with these data sets and presumably require improvement in the EPA M29 data. The EPA M29 samples from this set were run with both inductively coupled plasma-mass spectroscopy (ICP-MS) and ICP-atomic emission spectroscopy (AES) to try to verify the analysis results. Similar results were obtained from the alternate method. Further investigation into issues with the M29 variability of the Se data was beyond the scope of this project. 


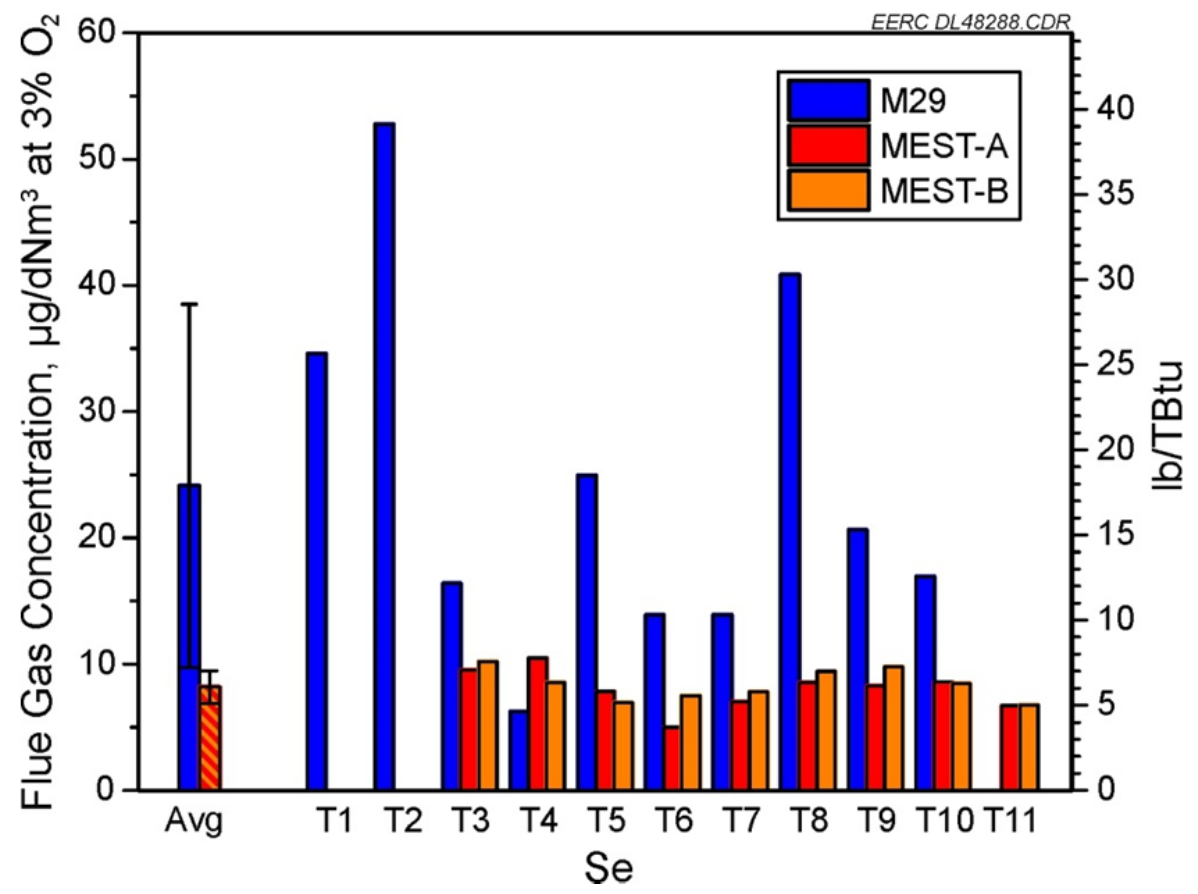

Figure C-22. Comparison of EPA M29 and ME-ST-M data for selenium, Plant 2. 


\section{POWER PLANT 3}

\section{Antimony, Sb}

The $\mathrm{Sb}$ results for Plant 3 are shown in Figure C-23. The lack of error bars on the average EPA M29 data indicates that the data are below the detection limit. The MATS limit is $0.8 \mathrm{lb} / \mathrm{TBtu}$ (approximately $1.08 \mu \mathrm{g} / \mathrm{dNm}^{3}$ at $3 \% \mathrm{O}_{2}$ ) for plants burning lignite for both new and existing sources. The ME-ST-M method data met all the QA/QC requirements and are equivalent to the EPA M29 data, but a detailed comparison of the data for bias and precision is not feasible since the EPA M29 reference method data are all less than values.

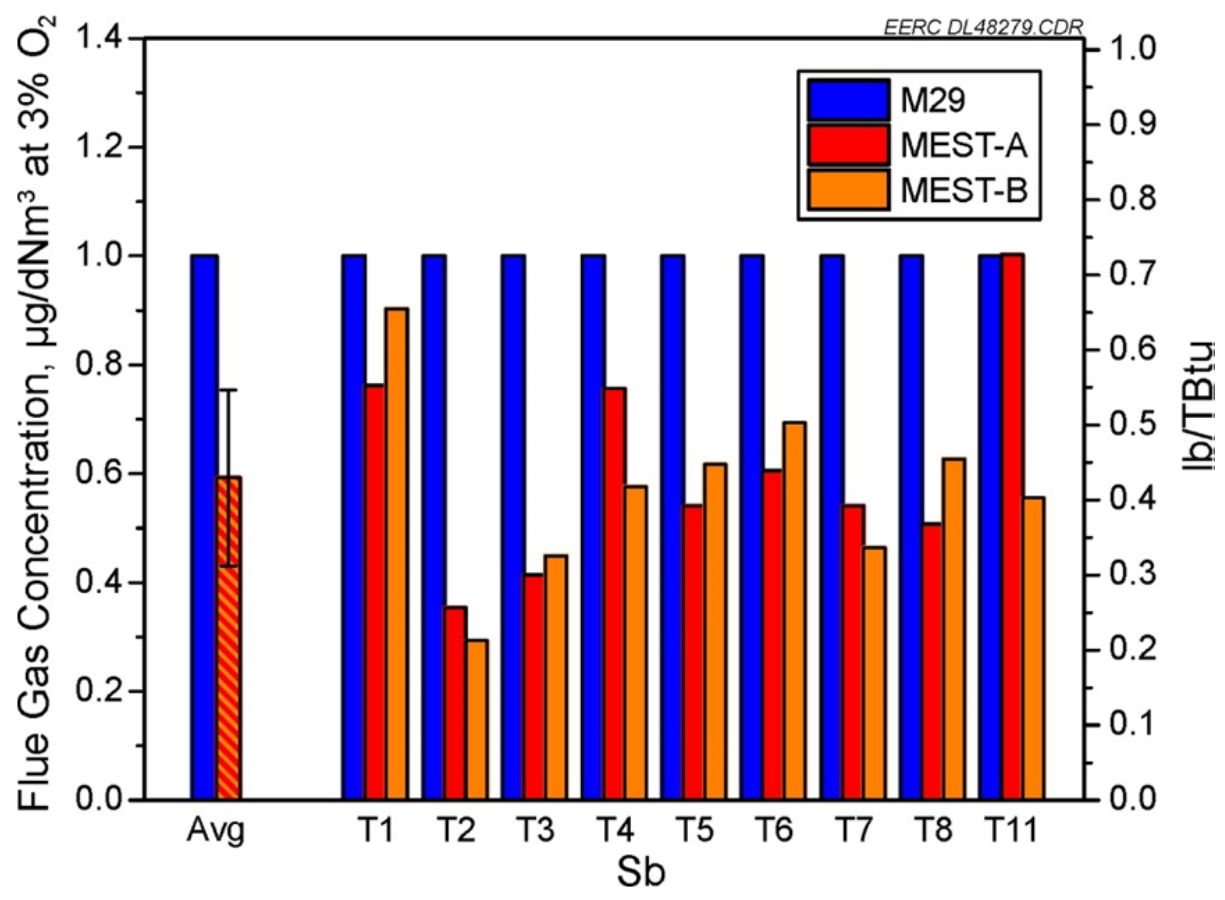

Figure C-23. Comparison of EPA M29 and ME-ST-M data for antimony, Plant 3. 


\section{Arsenic, As}

The As results for Plant 3 are shown in Figure C-24. For plants burning lignite, the MATS limits are $1.1 \mathrm{lb} /$ TBtu (approximately $2.65 \mu \mathrm{g} / \mathrm{dNm}^{3}$ at $3 \% \mathrm{O}_{2}$ ) for existing sources and $0.003 \mathrm{lb} / \mathrm{TBtu}$ (approximately $0.40 \mu \mathrm{g} / \mathrm{dNm}^{3}$ at $3 \% \mathrm{O}_{2}$ ) for new sources. It can be seen that both methods show that the As emissions are above the MATS limit for the unit. The ME-ST-M method data met the QA/QC requirements for breakthrough $(<5 \%)$ for all 18 traps. The QA/QC requirement for $\mathrm{RD}$ was met for seven of the nine paired traps $(<20 \%)$, with failures of $24 \%$ for Test 3 and 29\% for Test 8 . Even though these data fail the RD criterion, it can be seen that these data are not outside the range of the data set, so they were not thrown out for the comparison and statistical evaluation of the method. The average data for the methods appear similar, but the consistency of the data shows more variability for the ME-ST-M method.

Although this data set is too small for a complete M301 field validation, the data were used to investigate bias and precision using a similar approach. The significance of the bias was determined with a bias analysis, and the t-statistic was calculated to be 1.43 , showing the bias to be insignificant at the $95 \%$ confidence level $\left(>t_{\mathrm{s}}=2.306\right)$. The precision of the two methods was statistically compared with a modified $F$ test (modified for the smaller data set) and was shown to pass. The variance of the paired trap value $\left(\mathrm{S}_{\mathrm{P}}^{2}\right)$ of 4.1124 and a variance of the EPA M29 data $\left(\mathrm{S}^{2} \mathrm{~V}\right)$ of 2.8109 resulted in an $\mathrm{F}$ value of 1.4630 , which is less than the one-sided $\mathrm{F}$ value of 3.1789 for 9 degrees of freedom.

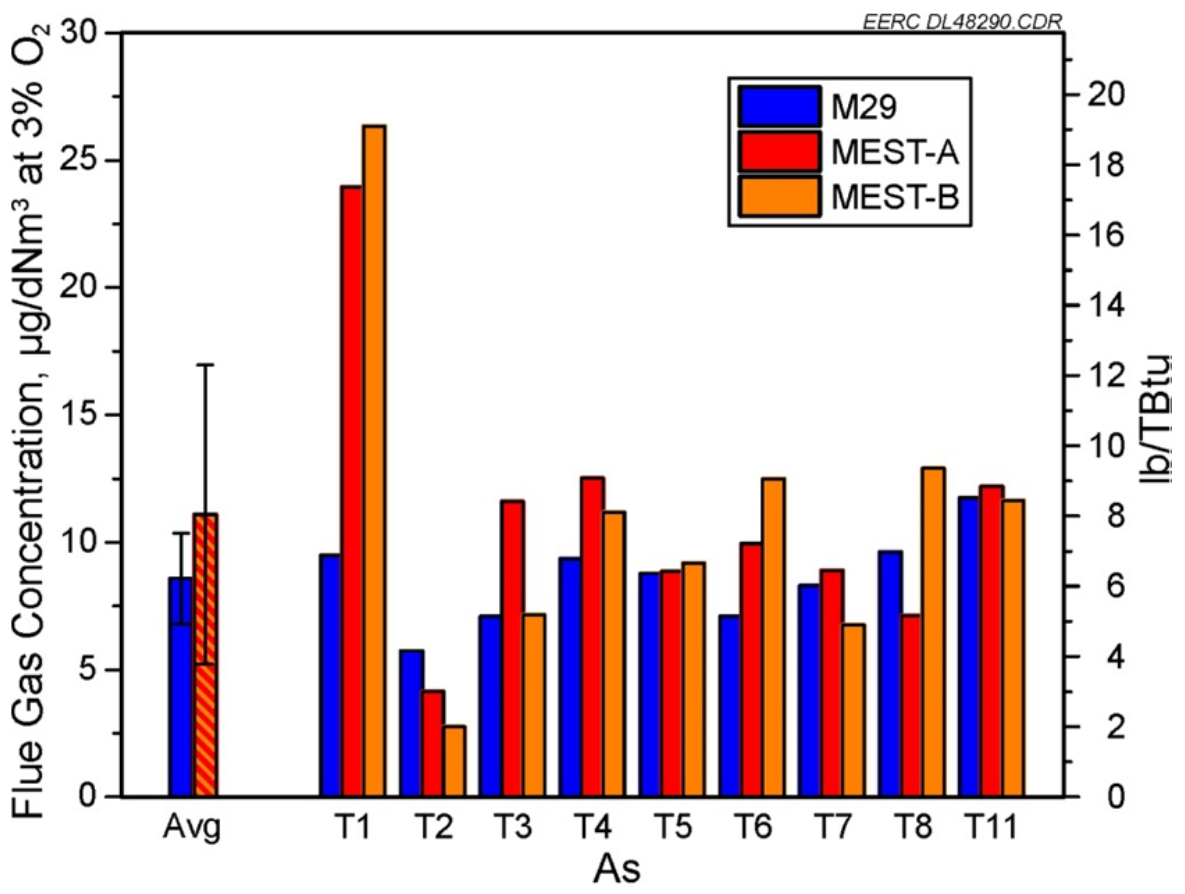

Figure C-24. Comparison of EPA M29 and ME-ST-M data for arsenic, Plant 3. 


\section{Beryllium, Be}

The Be results for Plant 3 are shown in Figure C-25. For plants burning lignite, the MATS limits are $0.2 \mathrm{lb} /$ TBtu (approximately $0.27 \mu \mathrm{g} / \mathrm{dNm}^{3}$ at $3 \% \mathrm{O}_{2}$ ) for existing sources and $0.0006 \mathrm{lb} / \mathrm{TBtu}$ (approximately $0.073 \mu \mathrm{g} / \mathrm{dNm}^{3}$ at $3 \% \mathrm{O}_{2}$ ) for new sources. Both methods show the emission levels are above the MATS limit for the plant. The ME-ST-M method data met the QA/QC requirements for breakthrough $(<5 \%)$ for all of the 18 traps, and the QA/QC requirement for RD was met for seven of the nine paired traps $(<20 \%)$ with failures for Tests 2 and 3 . The data for each method appear consistent, with the exception of the ME-ST-M data for T1 and T2. The average data, shown on the left of the graph, show a high bias for the ME-ST-M method as compared to the EPA M29 reference method. Although this data set is too small for a complete M301 field validation, the data were used to investigate bias and precision using a similar approach. The significance of the bias was determined with a bias analysis, and the t-statistic was calculated to be 3.20, showing the bias to be significant at the $95 \%$ confidence level $\left(>t_{\mathrm{s}}=\right.$ 2.306). The bias was then calculated using the differences between the two methods, with a result of $49.2 \%$, which is outside the range of $30 \%$ to be acceptable.

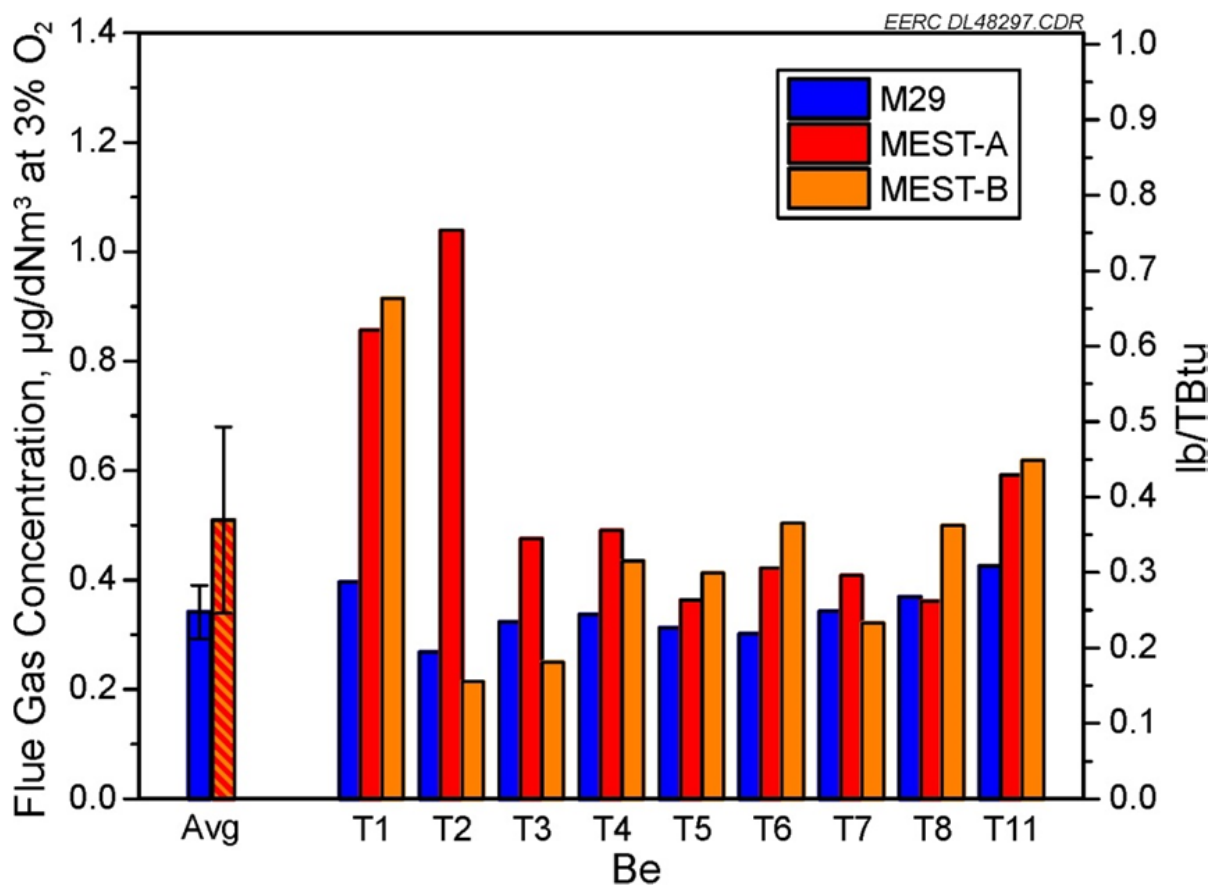

Figure C-25. Comparison of EPA M29 and ME-ST-M data for beryllium, Plant 3. 


\section{Cadmium, Cd}

The Cd results for Plant 3 are shown in Figure C-26. For plants burning lignite, the MATS limits are $0.3 \mathrm{lb} / \mathrm{TBtu}$ (approximately $0.41 \mu \mathrm{g} / \mathrm{dNm}^{3}$ at $3 \% \mathrm{O}_{2}$ ) for existing sources and $0.0004 \mathrm{lb} / \mathrm{TBtu}$ (approximately $0.053 \mu \mathrm{g} / \mathrm{dNm}^{3}$ at $3 \% \mathrm{O}_{2}$ ) for new sources. Both methods show the emission levels are above the MATS limit for the plant. The ME-ST-M method data for this data set are not valid because of the background correction, and the background levels contribute to a bias and variance (precision) that would fail a M301 validation. These data clearly show that the background for $\mathrm{Cd}$ is variable, indicating an external source of contamination. At the levels required by the regulations, the current background is significant, and further reduction of the background is required to be able to utilize the method at these levels.

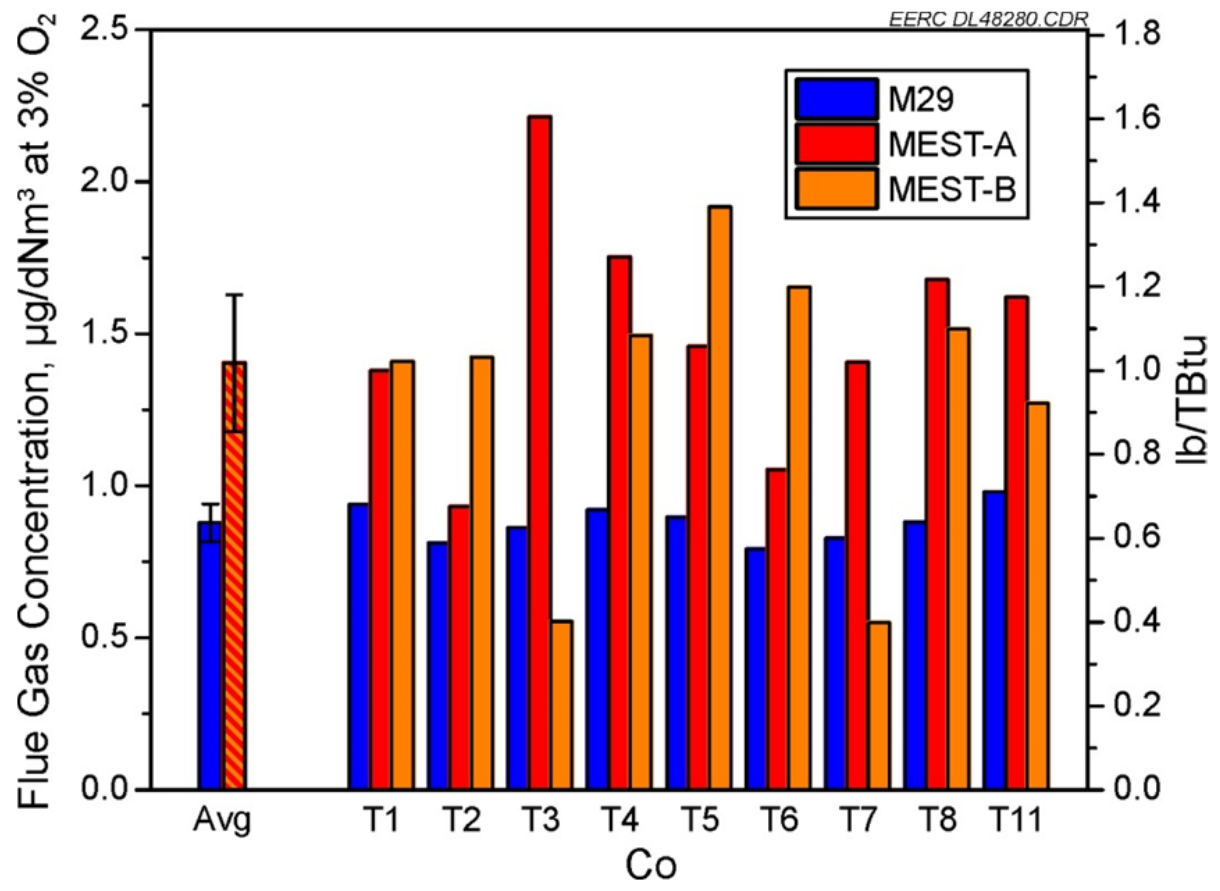

Figure C-26. Comparison of EPA M29 and ME-ST-M data for cadmium, Plant 3. 


\section{Chromium, Cr}

The Cr results for Plant 3 are shown in Figure C-27. For plants burning lignite, the MATS limits are $2.8 \mathrm{lb} /$ TBtu (approximately $3.99 \mu \mathrm{g} / \mathrm{dNm}^{3}$ at $3 \% \mathrm{O}_{2}$ ) for existing sources and $0.007 \mathrm{lb} / \mathrm{TBtu}$ (approximately $0.93 \mu \mathrm{g} / \mathrm{dNm}^{3}$ at $3 \% \mathrm{O}_{2}$ ) for new sources. EPA M29 data show the emission levels are near the MATS limit for the plant, but are above the limit. From the flagging notations in the data tables, it is known that neither method produced valid data because of background correction. The background levels for both methods would make a comparison for M301 validation difficult if not meaningless without first reducing the background levels. These data clearly show that the background for $\mathrm{Cr}$ is variable, indicating an external source of contamination. At the levels required by the regulations, the current background is significant, and further reduction of the background is required to be able to utilize either of these methods at these levels.

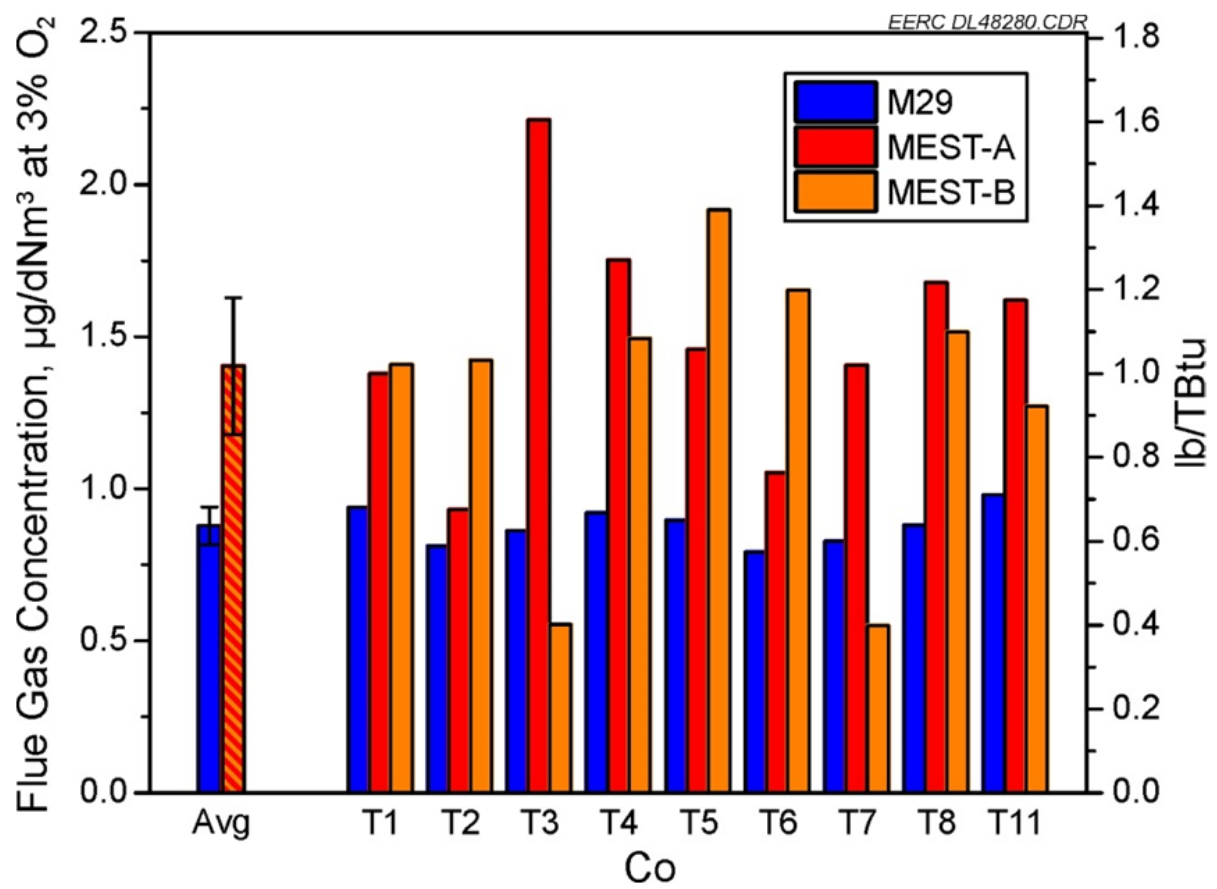

Figure C-27. Comparison of EPA M29 and ME-ST-M data for chromium, Plant 3. 


\section{Cobalt, Co}

The Co results for Plant 3 are shown in Figure C-28. For plants burning lignite, the MATS limits are $0.8 \mathrm{lb} /$ TBtu (approximately $1.08 \mu \mathrm{g} / \mathrm{dNm}^{3}$ at $3 \% \mathrm{O}_{2}$ ) for existing sources and $0.0002 \mathrm{lb} / \mathrm{TBtu}$ (approximately $0.27 \mu \mathrm{g} / \mathrm{dNm}^{3}$ at $3 \% \mathrm{O}_{2}$ ) for new sources. Both methods show the emission levels are near the MATS limit for the plant, with the EPA M29 result below the limit. The ME-ST-M method data met the QA/QC requirements for breakthrough $(<5 \%)$ for 16 of the 18 traps, with failures for Traps T3-A (5.8\%) and T11-A (8.7\%). The QA/QC requirement for $\mathrm{RD}$ was not met for four of the nine paired traps $(<20 \%)$. The average data, shown on the left of the graph, appear comparable for the two methods. Although this data set is too small for a complete M301 field validation, the data were used to investigate bias and precision using a similar approach. The significance of the bias was determined with a bias analysis, and the tstatistic was calculated to be 7.97 , showing the bias to be significant at the $95 \%$ confidence level $\left(>t_{s}=2.306\right)$. The bias was then calculated using the differences between the two methods, with a result of $59 \%$ outside the range of $30 \%$ that is acceptable.

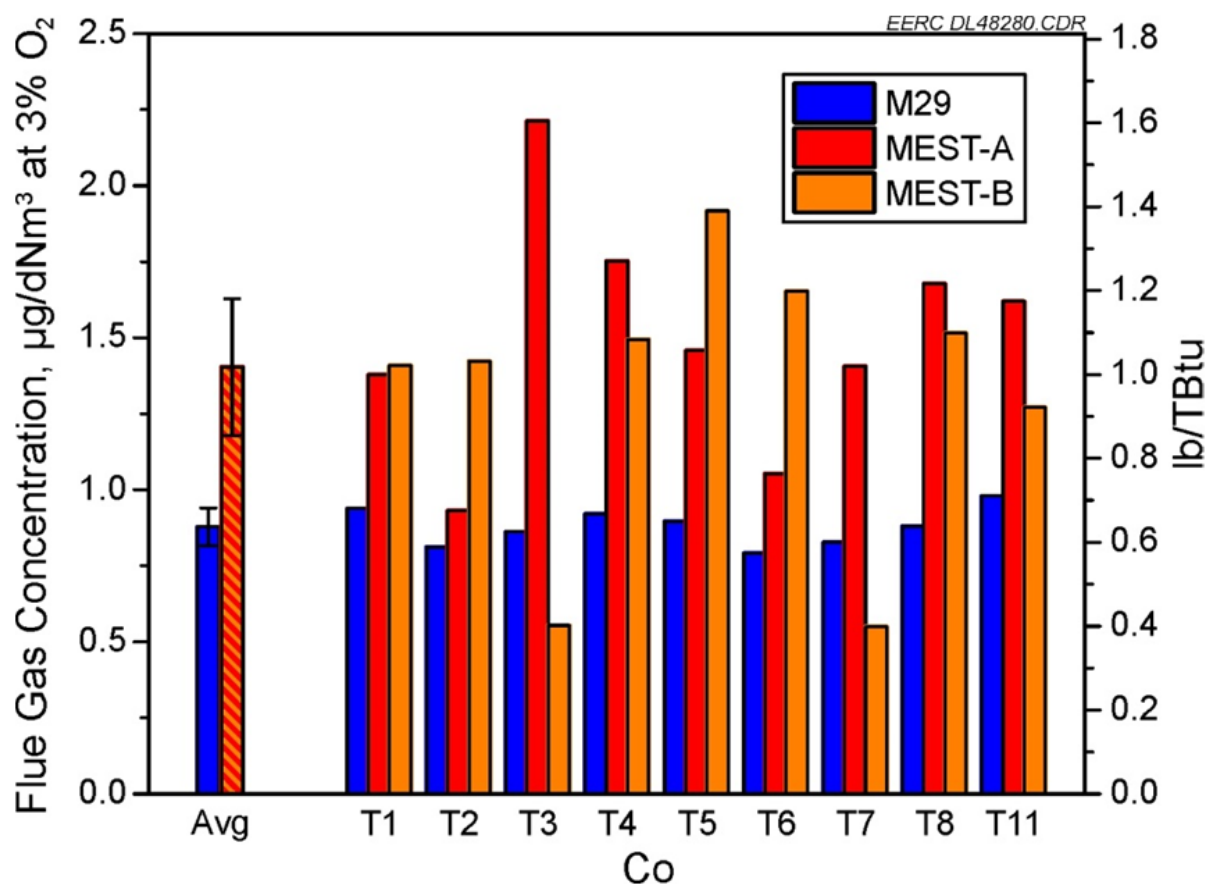

Figure C-28. Comparison of EPA M29 and ME-ST-M data for cobalt, Plant 3. 


\section{Lead, $\mathbf{P b}$}

The $\mathrm{Pb}$ results for Plant 3 are shown in Figure $\mathrm{C}-29$. For plants burning lignite, the MATS limits are $1.2 \mathrm{lb} /$ TBtu (approximately $2.65 \mu \mathrm{g} / \mathrm{dNm}^{3}$ at $3 \% \mathrm{O}_{2}$ ) for both existing and new sources. The EPA M29 show the emission levels are just over the MATS limit for the plant. From the flagging notations in the data tables, it is known that the ME-ST-M method did not produce valid data because of background correction. The average data, shown on the left of the graph, show significant variability for the ME-ST-M method, with a bias high for the ME-ST-M method as compared to the reference EPA M29 method. The ME-ST-M method data for this data set are not valid because of the background correction, and the background levels contribute to a bias and variance (precision) that would fail a M301 validation. The ME-ST-M method data met the QA/QC requirements for breakthrough $(<5 \%)$ for 17 of the 18 traps, with one failure for Trap T11-A. The ME-ST-M method data met the QA/QC requirements for RD for six of the nine paired traps $(<20 \%)$. These data clearly show that the background for $\mathrm{Pb}$ is variable, indicating an external source of contamination. At the levels required by the regulations, the current background is significant, and further reduction of the background is required to be able to utilize the method at these levels.

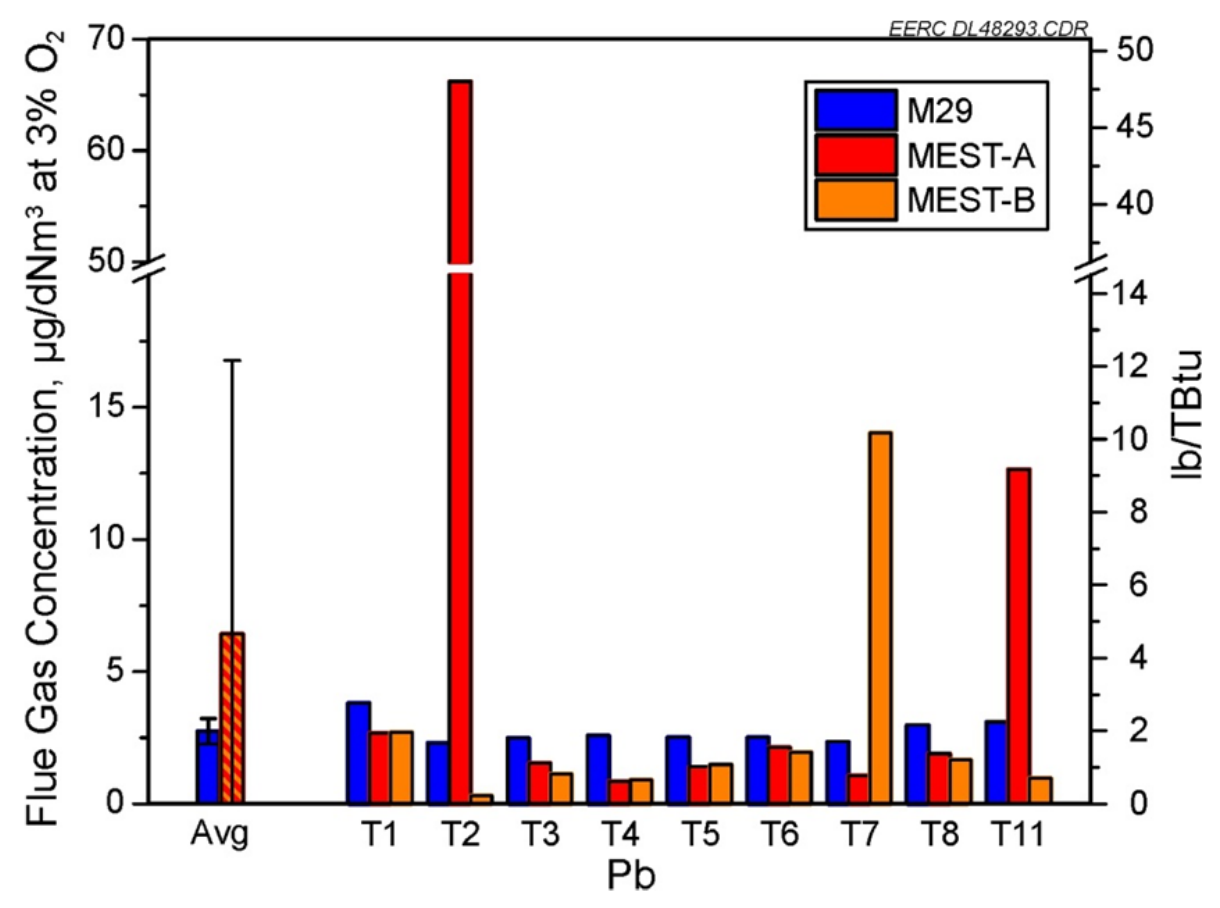

Figure C-29. Comparison of EPA M29 and ME-ST-M data for lead, Plant 3. 


\section{Manganese, Mn}

The Mn results for Plant 3 are shown in Figure C-30. For plants burning lignite, the MATS limits are $4.0 \mathrm{lb} /$ TBtu (approximately $6.63 \mu \mathrm{g} / \mathrm{dNm}^{3}$ at $3 \% \mathrm{O}_{2}$ ) for existing sources and $0.004 \mathrm{lb} / \mathrm{TBtu}$ (approximately $0.53 \mu \mathrm{g} / \mathrm{dNm}^{3}$ at $3 \% \mathrm{O}_{2}$ ) for new sources. It can be seen that the data for both methods show that the emission levels are above the MATS limit for the plant. From the flagging notations in the data tables, it is known that both methods had some difficulty and produced some invalid data because of background correction. The background levels for the EPA M29 method would make a comparison for M301 validation difficult if not meaningless without first reducing the background levels. These data clearly show that the background for $\mathrm{Mn}$ is variable, indicating an external source of contamination. At the levels required by the regulations, the current background is significant for both methods, and further reduction of the background is required to be able to utilize either of these methods at these levels and at lower levels required by the regulations.

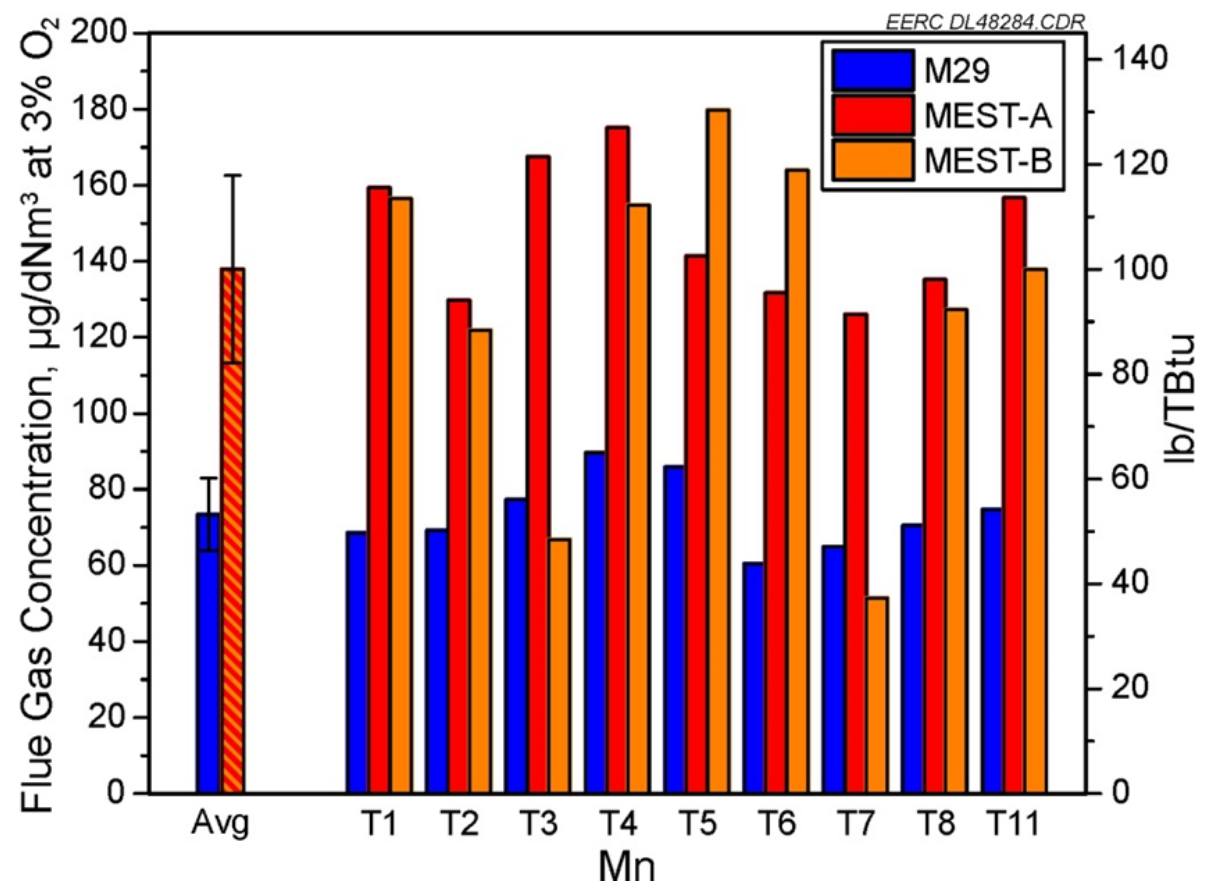

Figure C-30. Comparison of EPA M29 and ME-ST-M data for manganese, Plant 3. 


\section{Mercury, Hg}

The $\mathrm{Hg}$ results for Plant 3 are shown in Figure C-31. For plants burning lignite, the MATS limits are $4.0 \mathrm{lb} / \mathrm{TBtu}$ (approximately $5.42 \mu \mathrm{g} / \mathrm{dNm}^{3}$ at $3 \% \mathrm{O}_{2}$ ) for existing and new sources. It can be seen that both methods show that the $\mathrm{Hg}$ emissions are below the MATS limit for the unit as a result of the mercury control technologies in place. The ME-ST-M method data met the QA/QC requirements for breakthrough $(<5 \%)$ for all but one of the traps, T11-A. The QA/QC requirements for $\mathrm{RD}$ were met for all of the nine paired traps $(<20 \%)$. The data show some variability over the nine tests, but appears to track for both methods, indicating that the variability is a result of changing flue gas concentrations. The average data, shown on the left of the graph, show a comparable average for the ME-ST-M method as compared to the reference EPA M29 method.

Although this data set is too small for a complete M301 field validation, the data were used to investigate bias and precision using a similar approach. The significance of the bias was determined with a bias analysis, and the t-statistic was calculated to be 1.06, showing the bias to be insignificant at the $95 \%$ confidence level $\left(>t_{\mathrm{s}}=2.306\right)$. The precision of the two methods was statistically compared with a modified $F$ test (modified for the smaller data set) and was shown to pass. The variance of the paired trap value $\left(\mathrm{S}_{\mathrm{P}}^{2}\right)$ of 0.0209 and a variance of the EPA M29 data $\left(\mathrm{S}^{2} \mathrm{~V}\right)$ of 0.2347 resulted in an $\mathrm{F}$ value of 0.0889 , which is less than the one-sided $\mathrm{F}$ value of 3.1789 for 9 degrees of freedom.

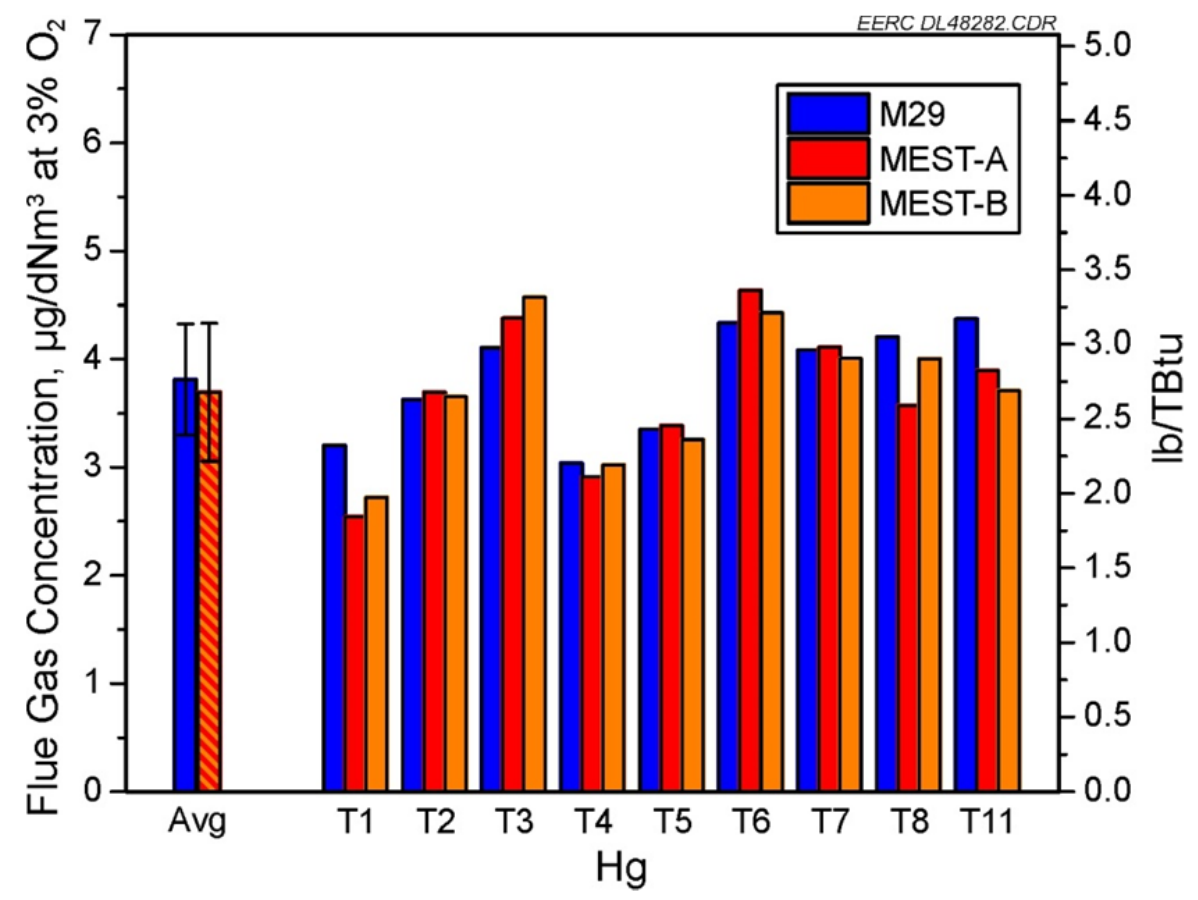

Figure C-31. Comparison of EPA M29 and ME-ST-M data for mercury, Plant 3. 


\section{Nickel, Ni}

The Ni results for Plant 3 are shown in Figure C-32. For plants burning lignite, the MATS limits are $3.5 \mathrm{lb} / \mathrm{TBtu}$ (approximately $5.31 \mu \mathrm{g} / \mathrm{dNm}^{3}$ at $3 \% \mathrm{O}_{2}$ ) for both existing and new sources. It can be seen that both methods show the emission levels are below the MATS limit for the plant. From the flagging notations in the data tables, it is known that neither method produced valid data because of background correction. The background levels for both methods would make a comparison for M301 validation difficult if not meaningless without first reducing the background levels. At the levels required by the regulations, the current background is significant for both methods, and further reduction of the background is required to be able to utilize either of these methods at these levels.

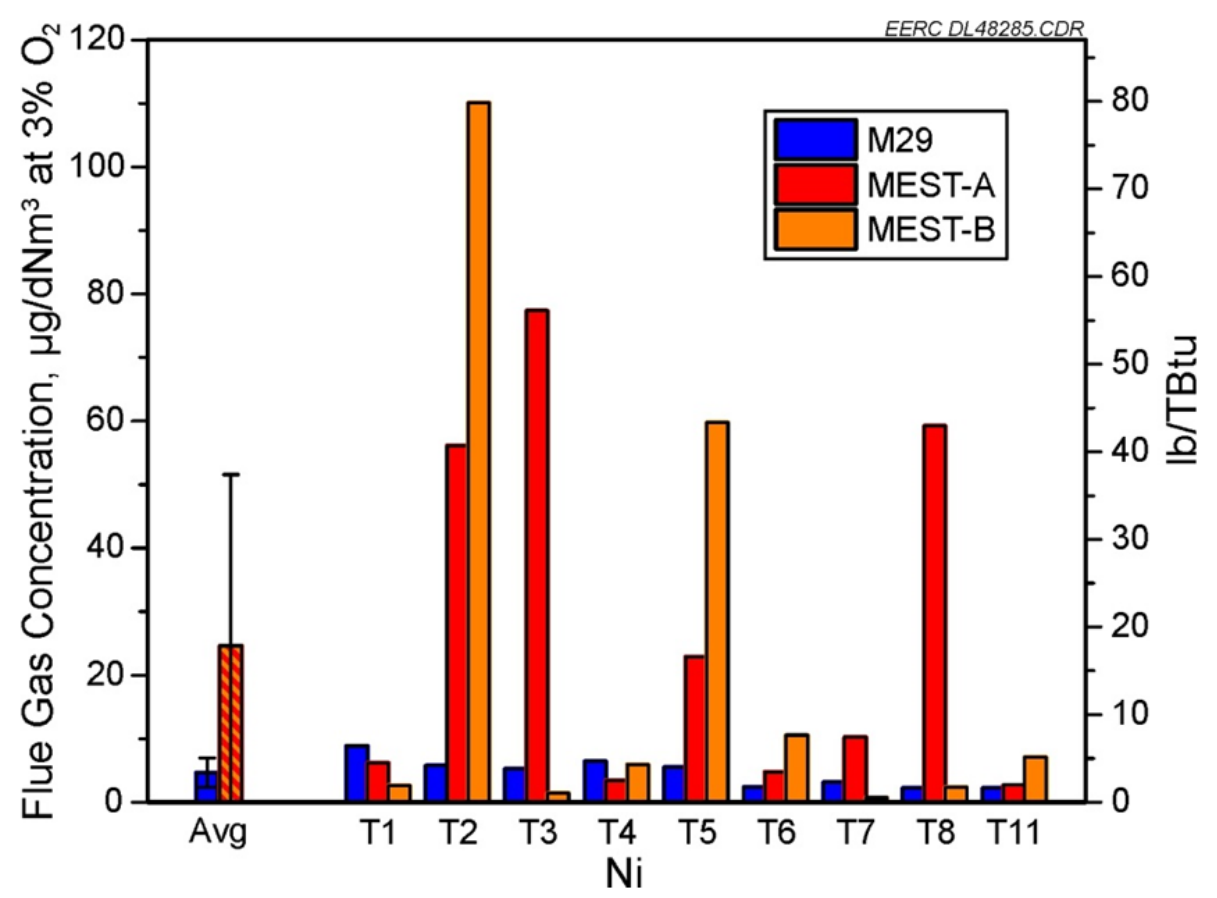

Figure C-32. Comparison of EPA M29 and ME-ST-M data for nickel, Plant 3. 


\section{Selenium, Se}

The Se results for Plant 3 are shown in Figure C-33. For plants burning lignite, the MATS limits are $5.0 \mathrm{lb} /$ TBtu (approximately $7.96 \mu \mathrm{g} / \mathrm{dNm}^{3}$ at $3 \% \mathrm{O}_{2}$ ) for existing sources and $0.05 \mathrm{lb} / \mathrm{TBtu}$ (approximately $6.67 \mu \mathrm{g} / \mathrm{dNm}^{3}$ at $3 \% \mathrm{O}_{2}$ ) for new sources. The data for EPA M29 indicate that the emissions are above the limit, but the ME-ST-M method indicates that the emissions are below the MATS limit for the unit. The average data, shown on the left of the graph, show a significant difference between the methods. The ME-ST-M method data met all the QA/QC requirements for breakthrough $(<5 \%)$ and for RD of the nine paired traps $(<20 \%)$.

Although this data set is too small for a complete M301 field validation, the data were used to investigate bias and precision using a similar approach. The significance of the bias was determined with a bias analysis, and the t-statistic was calculated to be 12.54 , showing the bias to be significant at the $95 \%$ confidence level $\left(>t_{s}=2.365\right)$. The bias was then calculated using the differences between the two methods, with a result of $30.2 \%$, which is just outside the range of $30 \%$ to be acceptable. For informational purposes, the precision of the two methods was statistically compared with a modified $F$ test (modified for the smaller data set) and was shown to pass. The variance of the paired trap value $\left(\mathrm{S}_{\mathrm{P}}^{2}\right)$ of 0.1663 and a variance of the EPA M29 data $\left(\mathrm{S}^{2} \mathrm{~V}\right)$ of 0.1180 resulted in an $\mathrm{F}$ value of 1.4091 , which is less than the one-sided $\mathrm{F}$ value of 3.1789 for 9 degrees of freedom.

For this data set, the data show that there is a bias for Se between the EPA M29 and the ME-ST-M method and that the bias is significant, slightly beyond acceptable M301 criteria.

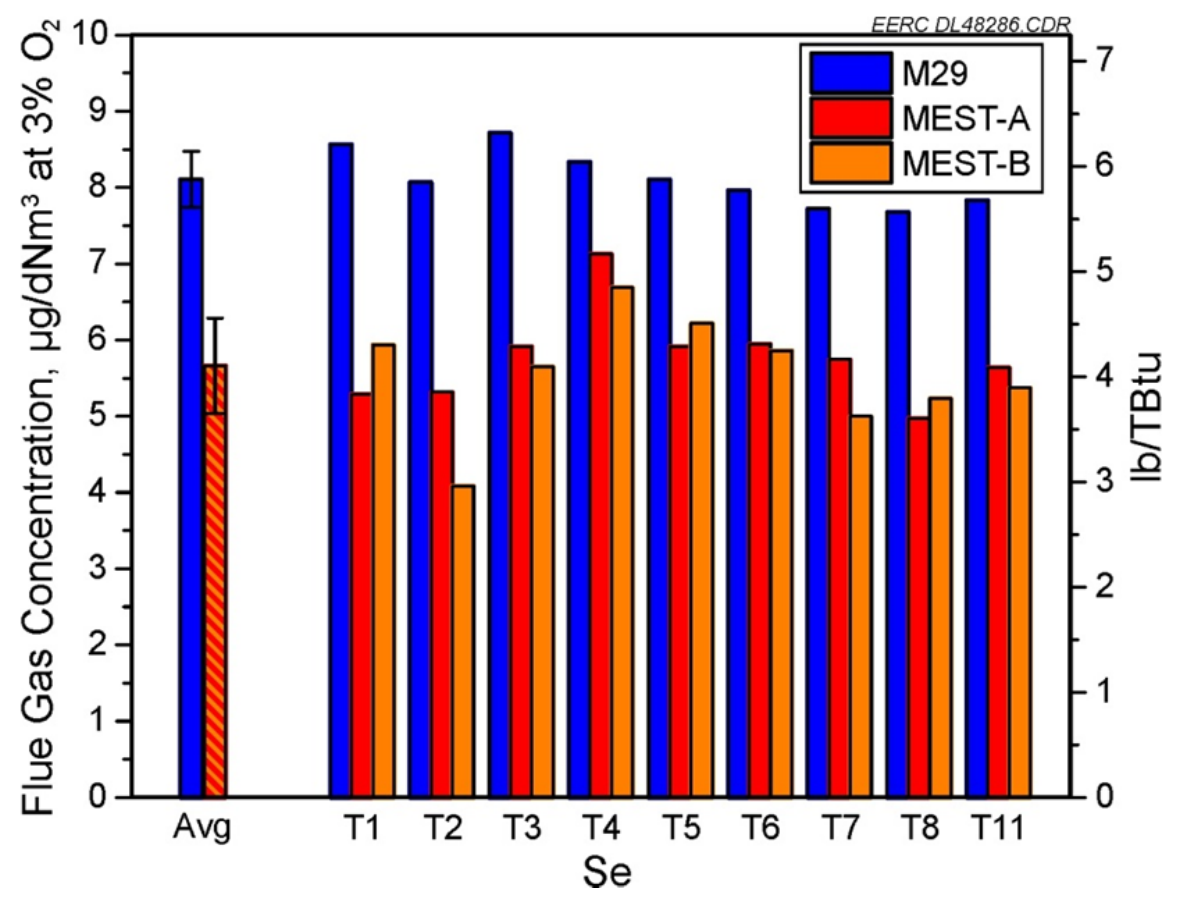

Figure C-33. Comparison of EPA M29 and ME-ST-M data for selenium, Plant 3. 